


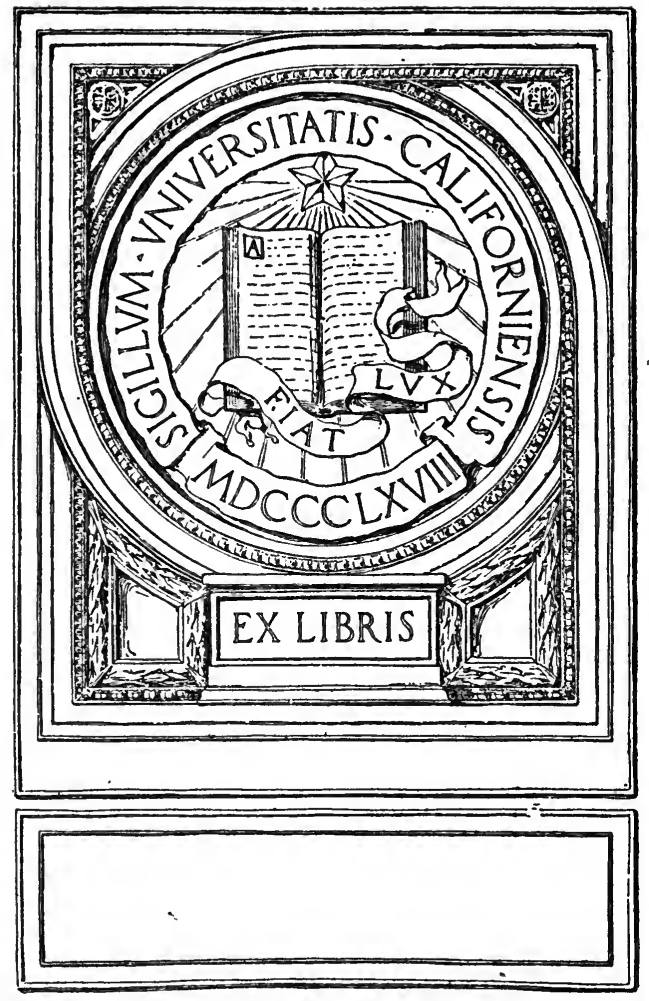



Digitized by the Internet Archive in 2007 with funding from Microsoft Corporation 


\section{ORGANIZED 'EFFORTS \\ FOR THE IMPROVEMENT OF METHODS OF ADMINISTRATION IN THE UNITED STATES}




\section{PUBLICATIONS OF THE \\ INSTITUTE FOR GOVERNMENT RESEARCH}

\section{STUDIES IN ADMINISTRATION}

The System of Financial Administration of Great Britain

By W. F. Willoughby, W. W. Willoughby and S. M. Lindsay

The Budget

By René Stourm

T. Plazinski, Translator, W. F. McCaleb, Editor

The Canadian Budgetary System

By H. C. Villard and W. W. Willoughby

The Problem of a National Budget

By W. F. Willoughby

The Movement for Budgetary Reform in the States

By W. F. Willoughby

Teachers' Pension Systems in the United States

By Paul Studensky

Organized Efforts for the Improvement of Methods of Administration in the United States

By Gustavus A. Weber

The System of Financial Administration of the United States (In preparation)

\section{PRINCIPLES OF ADMINISTRATION}

Principles Governing the Retirement of Public Employees By Lewis Meriam

Principles of Government Purchasing

By A. G. Thomas

SERVICE MONOGRAPHS OF THE UNITED STATES GOVERNMENT

The United States Geological Survey

The Reclamation Service

D. ÁPPLETON AND COMPANY 
THE INSTITUTE FOR GOVERNMENT RESEAKCH

\title{
ORGANIZED EFFORTS \\ FOR THE IMPROVEMENT OF METHODS OF ADMINISTRATION IN THE UNITED STATES
}

\author{
$B Y$, \\ GUSTAVUS A. WEBER
}

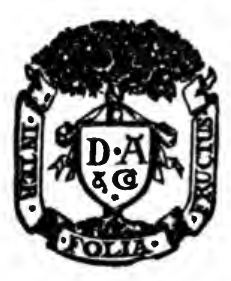

D. APPLETON AND COMPANY NEW YORK 
Geplacing 46870

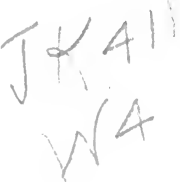

COPYRIGHT, I9I9, BY

THE INSTITUTE FOR GOVERNMENT RESEARCH

Printed in the United States of America 


\section{THE INSTITUTE FOR GOVERNMENT RESEARCH}

Washington, D. C.

The Institute for Government Research is an association of citizens for cooperating with public officials in the scientific study of administrative methods with a view to promoting efficiency in government and advancing the science of administration. It aims to bring into existence such information and materials as will aid in the formation of public opinion, and will assist officials, particularly those of the national government, in their efforts to put the public administration upon a more efficient basis.

To this end, it seeks by the thoroughgoing study and examination of the best administrative practice, public and private, American and foreign, to formulate those principles which lie at the basis of all sound administration, and to determine their proper adaptation to the specific needs of our public administration.

The accomplishment of specific reforms the Institute recognizes to be the task of those who are charged with the responsibility of legislation and administration; but it seeks to assist, by scientific study and research, in laying a solid foundation of information and experience upon which such reforms may be successfully built.

While some of the Institute's studies find application only in the form of practical cooperation with the administrative officers directly concerned many are of interest to other administrators and of general educational value. The results of such studies, the Institute purposes to publish in such form as will insure for them the widest possible utilization.

Robert S. Brookings, Chairman

\section{Officers}

Frank J. Goodnow,

$$
\text { Vice-Chairman }
$$

Frederick Strauss,

Treasurer

\section{Trustees}

Edwin A. Alderman

Robert S. Brookings

James F. Curtis

R. Fulton Cutting

Raymond B. Fosdick
Felix Frankfurter

Frank J. Goodnow

Jerome D. Greene

Arthur T. Hadley

Cesar Lombardi

Theodore N. Vail

James F. Curtis, Secretary

\section{Director}

W. F. Willoughby

\section{Editor}

Lewis Mayers 


\section{EDITORIAL PREFACE}

THE following volume is intended as one of reference. Its purpose is not to discuss principles nor, primarily at least, to describe what has been accomplished by organized efforts for the improvement of methods of public administration in the United States. Its principal aim is to furnish an account of the organized agencies that have been established in recent years for making scientific studies of problems of organization and administration with a view to bringing about more efficient methods in the conduct of public business, and of making known the character of the exceedingly valuable material that has resulted from these studies. At the same time, it is hoped that, as an incidental product, additional stimulus and encouragement will be given to the general movement for introducing scientific methods not only into public administration itself, but to the study of the principles which lie at the basis of good government.

To keep the volume within reasonable limits, it has been thought best to restrict its scope to organizations and agencies whose chief if not exclusive interest is in the technique of administration, rather than in the larger problems of politics. The interest of associations like the American Political Science Association, the American Academy of Political and Social Science, and the New York Academy of Political Science, extends to the whole field of scientific political thought, and only incidentally and casually to the practical problems of public administration. Other societies like the American Society of International Law and the American and State Bar Associations, have a more limited field, but they also are able to devote but a partial interest to questions of administration. The Short Ballot Association puts forth a program which it is believed will at once improve the average character of persons elected to public office, and tend to improve administrative processes by securing a better integration of the administrative services; but its primary interest is in the political machinery of elections. Again, the work of 
not a few important scientific associations, which are not primarily political, none the less often has a political character, and their publications not infrequently include papers dealing with problems of public administration. Such societies are the American Economic Association, the American Sociological Society, the American Historical Association, not to mention many others.

Enough has been said to show that if an adequate account were given of the incidental contributions of these scientific societies to the movement for the improvement of methods of public administration in this country, a separate volume would be required. It has, therefore, been thought best, as has been said, to confine this report to agencies whose work is not general or political, but which have for their immediate aim the bringing about of improved methods in public administration in the United States.

So various have been the forms assumed by these agencies for the improvement of administrative methods that satisfactorily to classify them is no easy task. Several broad lines of classification may however readily be discerned. Thus the agencies may be classified as to whether they are official or unofficial, or, as in the case of leagues of municipalities, what might be called semiofficial. Again, they may be classified as to their type of activity - that is, whether they merely furnish opportunity for the exchange of information and ideas among persons interested, by means of publications or conferences, or furnish information or advice on request, or themselves originate inquiries and attempt to secure the adoption of the views or principles developed, or, as in the case of certain official agencies, have legal power to require their adoption. Still another line of cleavage is between agencies seeking reform in legislative methods and those seeking it in judicial and administrative methods/

In determining what should be embraced in the limits of this volume, agencies devoting themselves solely to questions of judicial administration were regarded as representing too specialized an interest to be appropriate for inclusion here. Again, in the legislative field, agencies concerned chiefly with the content of legislative measures or the records of individual legislators-as voters' leagues, citizens' unions, etc.-have been excluded as having no primary concern with the technique of legislative methods.

Within the field of administration proper, moreover, no acviii 


\section{EDITORIAL PREFACE}

count, but merely a listing, has been attempted of those organizations whose regular program embraces no more than the publication of papers contributed by the membership, or other interested persons, or the holding of occasional conferences.

Primarily, therefore, the volume is devoted to those agencies which seek the improvement of methods of public administration (other than judicial) by the conduct of systematic inquiries, through staffs specially employed for the work. In giving account of these agencies distinction has been drawn between those which merely furnish information on inquiry-that is, reference libraries and bureaus-and those which themselves project and initiate investigations. In the latter class, distinction is again drawn between those agencies, both official and unofficial, whose function exhausts itself in the making of recommendations-that is, research agencies-and those few official agencies which possess legal power to translate their findings into action, agencies herein termed "central organs of administrative control." Lastly, among research agencies themselves, those which are interested only in one phase of administrative reform-as the civil service reform association-are distinguished from those which take the whole field of public administration for their province,

In addition to these agencies for administrative reform, which occupy the bulk of the volume, account is given of the billdrafting services which have been established in a number of states within recent years. While not strictly agencies for the improvement of legislative methods so much as themselves agencies employing improved methods in the framing of legislation, their basic relation to the problem of improving administrative methods has seeemd to warrant their inclusion.

In the case of all the research agencies treated the attempt has been made to describe the history, organization and activities and to list the publications of each agency separately. This has not been feasible in the case of all the other agencies. In some cases we have had to content ourselves with a consideration of them as a class, though what is believed to be a substantially complete list of such agencies has in all cases been given. Even with respect to the accounts given the agencies for research in government, it should be said that considerable difficulty was encountered in securing all the data desirable, and it is quite 


\section{EDITORIAL PREFACE}

likely that there are cases where the account given does not give full credit for work done.

The account given of the Institute for Government Research consists of a reproduction of a paper read by its Director at the annual meeting of the American Political Science Association in December, 1917, the use of which was kindly authorized by that association.

W. F. Willoughby. 


\section{CONTENTS}

Introduction: THE MODERN MOVEMENT FOR EFFICIENCY IN the Administration of PUblic Affairs .

\section{PART I. AGENCIES FOR RESEARCH IN GOVERNMENT}

I. Agencies for Studying Public Administration Generally: UnOFFicial (The Institute For Government RESEARCH)

II. Agencies for Investigating the National AdministraTION: OfFICIAL

Bibliography of Congressional Inquiries, $\mathrm{r} 789-\mathrm{I} 9 \mathrm{I}$ I . . $\quad 45$

Select Committee on Methods of Business in the Executive Departments (Cockrell Committee), r887-1889

Joint Commission on Executive Departments, Organization, etc. (Dockery-Cockrell Commission), r 893-1895

Committee on Department Methods (Keep Committee), I905-1909 • . • • • . $\cdot$.

President's Commission on Economy and Efficiency, rgro-rgr3 . . . . . . . . . 84

United States Bureau of Efficiency, I9r3 . . . 104

III. Agencies for Investigating the Administration of Particular States: Official . . . . . II 4

New Jersey: Economy and Efficiency Commission . . II5

Massachusetts: Commission on Economy and Efficiency in

New York: Committee of Inquiry to Investigate the Administration of the State Government . . . $\quad$ I 26

New York: Department of Efficiency and Economy . $\quad$ I 28

Pennsylvania: Economy and Efficiency Commission . 133

Illinois: Efficiency and Economy Committee. . . . I34

Minnesota: Efficiency and Economy Commission . . 144

Minnesota: Commission on Reorganization of Civil Administration . . . . . . . 146

Iowa: Joint Committee on Retrenchment and Reform . I47

Connecticut: State Commission on the Consolidation of

State Commissions and the Reorganization of the

Public Health Laws . $\quad . \quad$. $\quad$. $\quad$. 149

Kansas: Efficiency and Economy Committee . . I50 


\section{CONTENTS}

CHAPTER

Alabama: Legislative Investigating Committee . . I5I

Colorado: Survey Committee of State Affairs . $\quad 152$

Virginia: Commission on Economy and Efficiency . . I54

Louisiana: Board of State Affairs . . . . $\quad$ I57

Texas: Joint Legislative Investigating Committee . 158

Oregon: Consolidation Commission . . . . . 159

Other States . $\quad . \quad$. . . . . . . I6I

IV. Agencies for Investigating the Administration of

Particular States: Unofficial . . . . . 162

New Jersey: Bureau of State Research, State Chamber of

Commerce . . . . . . . . ${ }_{1} 62$

Maryland: Commission on Economy and Efficiency . 166

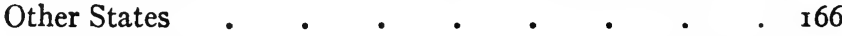

V. Agencies for Investigating the State and Local AdMinistration of Particular States: Unofficial . . I67

Ohio: Institute for Public Efficiency . . . . 167

Maryland: Bureau of State and Municipal Research . I7I

VI. Agencies for Studying Municipal Administration

GENERALLY: UNOFFICIAL $. \quad . \quad . \quad . \quad . \quad .173$

New York: Bureau of Municipal Research . . $\quad$ I73

VII. Agencies for Investigating the Administration of

Particular Cities: Official . . . . . . I9I

Boston, Mass.: Finance Commission of 1907-1909 . . I91

Boston, Mass.: Permanent Finance Commission . . . 194

Chicago, Ill.: Commission on City Expenditures . . 200

Chicago, Ill.: Efficiency Division of the Civil Service

Commission . . . . . . . 20I

Milwaukee, Wis.: Bureau of Economy and Efficiency and Bureau of Municipal Research. . . . 204

New York, N. Y.: Commissioner of Accounts . 206

Other Municipalities • • • • • • • 210

VIII. Agencies for Investigating the Administration of

Particular Cities: Unofficial . . . . . 2I 2

Philadelphia, Pa.: Bureau of Municipal Research . . 213

Cincinnati, Ohio: Bureau of Municipal Research . . 220

Chicago, Ill.: Bureau of Public Efficiency - • . 223

Dayton, Ohio: Bureau of Research . . . . 230

Milwaukee, Wis.: Citizens' Bureau of Municipal Efficiency . . . . . . . . 238

Minneapolis, Minn.: Bureau of Municipal Research of the Minneapolis Civic and Commerce Association . 242

Springfield, Mass.: Bureau of Municipal Research . 247

Akron, Ohio: Bureau of Municipal Research . . 250 


\section{CONTENTS}

Toronto, Canada: Bureau of Municipal Research . . 255

Denver, Colo.: Civic and Legislative Bureau of the Denver Civic and Commercial Association . . 258

Rochester, N. Y.: Bureau of Municipal Research . $\quad 260$

San Francisco, Cal.: Bureau of Government Research . 263

Detroit, Mich.: Bureau of Governmental Research • 265

Toledo, Ohio: Public Research Bureau: Toledo Commerce Club . . . . . . . . 266

Yonkers, N. Y.: Bureau of Municipal Research . . $\quad 267$

Indianapolis, Ind.: Bureau of Governmental Research of the Indianapolis Chamber of Commerce . . . 269

Columbus, Ohio: Bureau of Municipal Research . . 270

Memphis, Tenn.: Bureau of Municipal Research . . 270

Petersburg, Va.: Bureau of Governmental Research $27 \mathrm{I}$

IX. Agencies to Investigate the Administration of Par-

ticular Counties: UNOFficial . . . . . 272

Westchester County, N. Y.: Research Bureau . . 272

Alameda County, Calif.: Tax Association . . . 276

Hudson County, N. J.: Citizens Federation . • . $\quad 278$

\section{PART II. ORGANS OF CENTRAL ADMINISTRATIVE CONTROL}

X. Organs of Administrative Control in the States $\quad$. . 283

California: State Board of Control . . . . 284

Wisconsin: State Board of Public Affairs . . . 288

Massachusetts: Supervisor of Administration . . 29I

Illinois: Department of Finance . . . . . 296

Tennessee: State Budget Commission . . . . 298

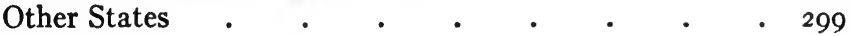

XI. Organs of Administrative Control in Cities . . . 30I

New York, N. Y.: Board of Estimate and Apportionment $30 \mathrm{I}$

\section{PART III. LEGISLATIVE REFERENCE AND BILL-DRAFTING AGENCIES}

XII. The Problem of Legislative Reference and BillDrafting Service.$\quad \cdot \quad \cdot \quad \cdot \quad \cdot \quad \cdot \quad \cdot 3 \mathrm{I} 3$

XiII. Agencies Furnishing Legislative Reference and Bill-

Drafting Service . . . . . . . 327

Alabama: Department of Archives and History . . 327

Arizona: State Law and Legislative Reference Library . 328

California: Legislative Counsel Bureau . . . 329

Illinois: Legislative Reference Bureau . . . . 330 
Indiana: Legislative and Statistical Bureau .

Kansas: State Library: Legislative Reference Department .

Maryland: Department of Legislative Reference

Michigan: State Library: Legislative Reference Department .

Missouri: Library Commission: Legislative Reference Department

Montana: State Library: Historical and Miscellaneous Department: Legislative Reference Bureau

Nebraska: Legislative Reference Bureau

New Hampshire: State Library: Legislative Reference Bureau

North Carolina: Historical Commission: Legislative Reference Department .

North Dakota: Public Library Commission: Legislative Reference Bureau

Ohio: State Board of Library Commissioners: Legislative Reference Department

Pennsylvania: Legislative Reference Bureau . . . 343

Rhode Island: State Library: Legislative Reference Bureau

South Dakota: State Library: Division of Legislative Reference

Vermont: State Library: Legislative Refercnce Bureau .

Virginia: Legislative Reference Burcau

West Virginia: Department of Archives and History: Legislative Reference Section

Wisconsin: Free Library Commission: Legislative Reference Department .

XIV. Legislative Reference Services

United States: Library of Congress: Legislative Reference Division . . . . . .

California: State Library: Legislative Reference Department . . . . . . .

Connecticut: State Library: Legislative Reference

Georgia: State Library: Legislative Reference $\dot{\text { Depart- }}$

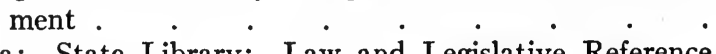

Iowa: State Library: Law and Legislative Reference Department

Maine: State Library: Legislative Reference Bureau .

Massachusetts: State Library: Legislative Reference Department

New Jersey: State Library: Legislative Reference Department . 


\section{CONTENTS}

CHAPTER PAGE

New York: State Library: Legislative Reference Section $\quad . \quad \cdot \quad \cdot \quad \cdot \quad \cdot \quad \cdot \quad \cdot 36 \mathrm{I}$

New-York: Legislative Library . . . . . $\quad .363$

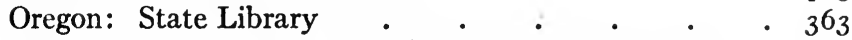

Texas: State Library: Legislative Reference Section . $36_{j}$

XV. Bill-drafting Services . . . . . . . . 365

Connecticut . . . . . . . . . 365

Massachusetts . . . . . . . . $\quad .366$

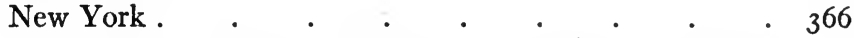

New York: Columbia University: Legislative Drafting

Bureau . . . . . . . . . 367

Wyoming • • . . . . . . . $\quad$. $37 \mathrm{I}$

Other States • 



\section{INTRODUCTION}

THE MODERN MOVEMENT FOR EFFICIENCY IN THE ADMINISTRATION OF PUBLIC AFFAIRS

BY

W. F. WILLOUGHBY 


\section{ORGANIZED EFFORTS FOR THE IMPROVEMENT OF METHODS OF ADMINISTRATION}

\section{INTRODUCTION}

At the time the federal constitution was adopted, more than one hundred and twenty-five years ago, the one great political problem which the men of that time felt called upon to solve was to obtain a form of government which, on the one hand, would have sufficient power and be so organized that it could maintain domestic order and afford protection against foreign aggression, and yet, on the other hand, subject the liberty and freedom of the individual to a minimum of interference and control. The idea dominant was to keep the sphere of governmental activities as limited as possible and so to distribute the political powers that were granted that they would check or balance one another, and thus tend to prevent the assumption and exercise by any one official or branch of the government of undue authority. Comparatively little emphasis was laid upon the problem of bringing into existence an efficient system of government from the modern viewpoint since it was the expectation that the government would in fact have but few positive duties to perform.

Such an ideal as this could remain satisfactory only so long as the functions of government remained comparatively few and simple and were, in fact, confined to what have been called police duties, using that term in its technical sense. Events, however, have entirely nullified this original conception. The performance of the so-called essential functions of government now constitute but a relatively small part of its total activities. No longer is there an a priori assumption that a widening of the sphere of public action is an evil. The province of government is now held to embrace all forms of 


\section{EFFORTS FOR ADMINISTRATIVE REFORM}

activities which contribute in any way to the promotion of the public welfare There is hardly a field of activity into which our governments have not entered. Their operations are now on a vast scale and require for their performance organizations and technical processes exceeding in size and complexity those of any private undertakings. Gone also is the early simple faith that there were intrinsic merits in democratic government which could be depended upon by their own inherent force, as it were, to provide a satisfactory formulation and execution of the popular will. Upon the contrary it is now recognized that, if anything, a popularly controlled government is one which is peculiarly prone to financial extravagance and administrative inefficiency. It is now seen that our original conceptions regarding the benefits of the separation of powers must be radically revised; that the rigid application of this principle is no longer needed as a protection against a possible autocratic and oppressive exercise of power; that within the administrative branch responsibility and power must be more strongly centralized and a more integrated system of administrative services be built up. And, finally, it has been recognized that many of the administrative tasks which the present day government has to perform are highly technical in character, technical as regards the information that must be at hand, and technical as to the methods of operation that must be employed, and that there are no inherent reasons why officers of government cannot be held to the same standards of efficiency and honesty which are exacted in the general business world.

Due to an appreciation of these facts, the center of interest and effort has shifted to the obtaining of an efficient and economical performance by governments of the tasks which are laid upon them. Thus it may be said that, in its present phase, the movement for political reform is one that lies very largely in the field of administration.

This change in interest is clearly reflected in the literature of political science in all countries as well as our own. It is well within the memory of many of us when works upon the government of the United States consisted almost wholly of commentaries upon the federal constitution. As a subject of study, government was deemed to embrace little more than 


\section{INTRODUCTION}

learning, usually by heart, the provisions of this document. Of the study of our extra-constitutional and extra-legal political institutions-parties, their organization, procedure and practices, and the part that they play in determining the manner in which our governmental machinery actually worksthere was not a trace. Political science, properly speaking, did not exist. Such questions as the nature of the state, sovereignty, the essential differences between different types of government, etc., if they received any attention at all, were given only incidental consideration in legal treatises. Not the first beginning was made of the study of problems of administration, of the manner in which Congress was organized for the discharge of its duties, of its rules of procedure, of the organization, practices and procedure of the executive departments, of the procedure and rules of the courts in administering justice, etc. This was the first stage in the study of government in the United States-the stage in which legal and political thought was dominated by the idea of natural law, when our constitutional system was looked upon as almost flawless, and when the study of politics was confined to the effort to learn in a colorless way the mere structure or framework of government and the manner in which it was put together.

In 1867 Walter Bagehot published his essay on The English Constitution. The appearance of this work constituted a landmark in the history of the study of political science. For the first time a thoroughly satisfactory attempt was made to study a governmental system from the standpoint of its practical operation, to search out the mainsprings of political action, to make known the significance of political conventions, practices and procedure, as distinguished from the formal rules determining the organization of government, in a word, to study a government as an actually operating machine, instead of as an inert structure. It was not, however, until after the lapse of a considerable number of years that any attempt was made to do a like work for the United States. In I885 President Wilson published his well-known work on Congressional Government, a work modeled on the plan of Bagehot's essay and attempting, and with eminent success, to do for the United States what that work had done for 


\section{EFFORTS FOR ADMINISTRATIVE REFORM}

the constitutional system of Great Britain. This was followed a few years later by James Bryce's great work The American Commonwealth, the first edition of which appeared in I888. From this period"also dates the inclusion in university curricula of advanced courses on comparative government and political institutions and the issue by universities of serials and periodicals dedicated to the publication of serious studies in the field of politics and the allied sciences. Among the latter the Johns Hopkins University Studies in Historical and Political Science, beginning in 1882, was the pioneer. Without the aid of the material contained in these studies James Bryce is reported to have said that a number of the chapters of his American Commonwealth could not have been written. In I886 was begun the publication, under the auspices of the Columbia University, of the Political Science Quarterly, a periodical which from its establishment has had the highest scientific character. Other serials, issued under the auspices of universities and political science associations, soon followed.

The appearance of these publications in the eighties marks the beginning of the second stage in the study of government in this country. This stage may be called the stage of interpretive and critical study. Its predominant note was its effort, not merely to describe, but to interpret and to criticize, to compare governments and political institutions with each other, to determine the significance of political practices. It constitutes the period when students began to question whether our constitutional system was in all respects the perfect one which it had been held to be, whether there were not features in other governmental systems that were not worthy of incorporation in our own. For the first time our whole political system and scheme of government, national, state and local, was subjected to critical examination in the light of actual results.

Great as was the advance of this stage over the one that had preceded it, it still fell short of meeting the demand that can properly be put upon political science. Though governmental systems here and abroad were subjected to the most searching criticism, little or no attempt was made to follow up such criticisms with definite suggestions regarding the ac- 


\section{INTRODUCTION}

tion which should be taken to remove the evils that were revealed. Students of political science were subjected to the indictment that though fertile enough in criticism they were barren in respect to the indication of means by which improvements might be brought about. Especially did the field of administration as a branch of political science remain wholly uncultivated. The actual administrator of public affairs, the legislator or the executive officer, though he found much of interest and not a little of profit in the writings of students of politics, was thrown upon his own resources when it came to working out plans by which concrete changes were to be effected.

This indictment of students of political science as a body no longer holds good. We are to-day in the midst of a period when the entire mechanism of our governmental system, federal, state, and local, is being subjected to a detailed examination for the purpose, not merely of criticizing, but of formulating definite proposals of reform. In contrast with the two periods that preceded it, the descriptive and the critical, this period may be designated as the period of constructive effort. In entering upon this new phase the study of political science may be said to have at last fully entered upon its own. Its prime characteristic is that governmental institutions are being taken up and studied one by one in the most intensive manner and that, on the basis of such study, concrete measures of reform are being both formulated and urged for adoption.

How widely divergent is this type of research from the traditional material of political science is apparent from the most summary outline of its problems. The problem of public administration is resolvable into five fairly distinct parts : problems of organization, problems of personnel, problems of material, problems of business practice and procedure, and problems of finance. Each of these, in turn, has its special phases. For example, problems of personnel have to do with the recruitment of the working force, how employees shall be classified, the basis on which their compensation shall be fixed, the manner of determining their efficiency through the establishment of efficiency records or otherwise, and the systems of promotions based thereon, what shall be the working conditions of employees in respect to such matters as permanency 
of tenure, hours of labor, leave privileges, etc., and finally, the provision that shall be made in the way of retirement allowances or pensions for those incapacitated while in the performance of their duties or as the result of age. In like manner, problems of finance include such questions as the system of handling and disbursing funds, of accounting and reporting, of audit, and, most important of all, of determining and making provision for the revenue and expenditure needs of the several services and of the government as a whole, or, to use the expression now commonly employed, of the budgetary system that shall be adopted. With the great increase of the operating functions of governments, especially as brought about in the national government at least by the increase in the military and naval establishments, the administrative problems connected with the acquirement, inspection, transportation, warehousing, distribution and accounting for supplies have assumed a complexity that makes imperative the employment of more systematic methods than have in the past been found, or at any rate, been deemed adequate.

These special problems have been mentioned as merely illustrative of the complexity and importance of the many problems that must be solved before the practical operation of government can be placed upon a satisfactory basis. For their solution, it now is recognized that two things are necessary: First, a greater fund of exact information than has heretofore been available; second, the formulation and adoption of scientifically determined principles of administrative organization and procedure. The facts which are needed include not merely a knowledge of foreign systems which may throw light upon our own problems, but also a knowledge of existing conditions in the United States, that is, a knowledge based upon exact and objective investigation and presented in a logical and available form. The adoption of proper principles of administrative organization and procedure means that methods will be employed not merely because they have the sanction of long-continued use, but because they are actually efficient and are dictated by a scientific analysis of the nature of the work to be done.

Much the most striking feature of this, the latest phase of the study of government, is the extent to which this study 


\section{INTRODUCTION}

is being carried on as the result of organized effort. The past decade or decade and a half has witnessed the establishment of a large number of organizations having for their primary or sole purpose the study of problems of administration, and generally the organization and methods of administration of a particular government, with a view to the devising and securing the adoption of means by which the organization and methods of administration of such government might be put upon a more efficient and economical basis. These organizations have been created under various auspices and pursue quite varied methods in seeking to accomplish their ends. Some have been established by the governments themselves and are thus of an official character. Others have been created and financed by private individuals. Others still represent merely the formation of associations for the study of problems of government in a particular field by those who are actually engaged in work in such field, or have made such field their special study. These organizations have now reached such a number, are prosecuting their work under such different circumstances, and are employing such diverse methods, that they furnish in themselves a problem of efficiency and economy in organization and administration. Both for this reason and because it is of interest to make a general presentation of work that has been, and is being, done in this field, the preparation of the present work has been undertaken.

Organized effort for the study of problems of administration has concerned itself with all three of the great branches of government,- the legislative, the judicial, and the executive. In the legislative field this effort has taken the form chiefly of the organization of what are known as legislative reference bureaus and bill-drafting services. These two are quite distinct in character and aim. The first have for their purpose the assembling and rendering available of the data that will permit of more intelligent legislation. The necessity for their establishment arises from the fact that legislators only rarely are either in possession of the knowledge which they should have if they are to frame their measures intelligently, or have the knowledge, means, or time at their disposal that will enable them to secure such information. Under modern conditions few subjects can be effectively leg- 


\section{EFFORTS FOR ADMINISTRATIVE REFORM}

islated upon without full knowledge regarding not only the past legislation of the state to be affected by the legislation proposed, and of other states, but of the manner in which this legislation has worked in actual practice. The securing of such information is usually a matter of careful research which is beyond the resources of the individual legislator. For the most part it can be promptly and efficiently secured only by specialists trained in the making of such inquiries, and having at their disposal the facilities necessary for the prosecution of such work. It is thus a hopeful sign that this need is being recognized and that in response to it organizations are being created for meeting it.

A survey of work that has been done in this field shows that organizations of this character have been established under three auspices, the legislatures for whose use they are intended, state and other libraries, and universities. Which of these three represents the most desirable form of action depends largely upon the particular conditions of each case. Generally speaking it would seem that a beginning. can best be made where there is a strong and well-organized library by having this work undertaken by such library. Later, if it is deemed expedient, the work can be given an independent status and organization.

The creation of bill-drafting services is a tardy recognition of the fact that a high degree of technical skill is required for the proper drafting of legislative measures. In no small degree the great burden of litigation under which our courts are staggering is due to the carelessness with which legislative acts are worded. When the language employed is not absolutely obscure or inconsistent with itself, there is often a failure to recognize the necessity for precision in defining the scope or character of action called for by the act. An act that is declared to apply to dangerous occupations and makes no adequate definition of what occupations shall be deemed to be dangerous, nor sets up any rule or machinery by which such knowledge may be had is manifestly either unworkable or one which throws a large amount of work upon the courts. Yet legislation of this character is being constantly put upon our statute books. Without enlarging further upon the errors in draftsmanship that may and are constantly being made, it 


\section{INTRODUCTION}

is sufficient to say that they are of a character that can be avoided by trained bill drafters. If well-formulated laws are to be had it is imperative, therefore, that the actual drafting of acts shall be entrusted to persons of proved competence. The most complete recognition of this fact is presented by the practice of the British Parliament, where all measures are either drawn by, or pass under, the scrutiny of the Office of the Parliamentary Counsel.

As in the case of legislative reference bureaus, efforts to establish bill-drafting services in this country have taken various forms. In some cases legislatures have provided for the establishment of a special committee whose duty it is to pass upon the wording of all bills before they are put upon their final passage. The committee may or may not be provided with paid counsel to assist it in its labors. In other words, they have established special services whose duty it is, not merely to scrutinize bills prepared by members, but, at the request of the latter, to draft bills in the first instance. It is quite feasible, and in many respects desirable, that the same service should perform both the functions of a legislative reference and a bill-drafting organ. Where legislatures have failed to act, bill-drafting services have been created under private auspices, and particularly under that of universities, the facilities of which have been placed at the disposition of legislators and others desiring to frame measures of public interest. Of services of this character that created by, or under the auspices of, Columbia University is probably the most important. Its aid in drafting important legislative measures has frequently been acknowledged.

If we turn now to the field of administration of justice we find a greatly aroused determination on the part of the public to put this important branch of administration upon a more efficient basis. It is true that for years our judicial organization, procedure, rules of evidence and procedural law generally governing the adjudication of legal issues have been subjected to a destructive criticism, and that important efforts have been made by our national, state and local bar associations to secure reform in respect to particular features or practices. It was not, however, until within comparatively recent years that the general public may be said to have been 


\section{EFFORTS FÒR ADMINISTRATIVE RĒFOTRM}

thoroughly aroused to the importance of the issues here presented. From a questioning of particular practices, the movement for reform has now taken the form of an examination of the whole system of administering justice. The demand is being made for a complete reorganization of our scheme of courts, for a complete recasting of our rules of procedure. Results of the utmost importance, moreover, are being accomplished. We need but cite the preparation by Congress of revised judicial and criminal codes of the United States, the elimination of the circuit courts from our federal judiciary, the promulgation by the Supreme Court of the United States of the revised rules of equity procedure, the establishment of the new municipal court of Chicago, the changes in judicial organization and procedure, and particularly in respect to the operation of the jury systems, effected by the recent revision of the constitution of Ohio, and finally the revolutionary change in the attitude of the courts themselves in respect to weight given to mere technicalities. From the standpoint of the present study the most important feature of this movement is the establishment of two national organizations having for their primary purpose the promotion of judicial reform,The American Institute of Criminal Law and Criminology and the American Judicature Society.

We have thought it advisable in the foregoing to make mention at least of the efforts now being made to effect improvements in legislative and judicial methods, since it is an essential part of our purpose to bring out the extent to which not only all branches of our government are being subjected to critical study, but constructive measures of reform are being both advocated and adopted. Our major interest, however, lies in the great movement which has come into existence during the past ten or fifteen years for the putting of the administrative branch of our governments, national, state and local, upon a more efficient and economical basis.

The pioneer in this movement was the Bureau of Municipal Research of New York City, and the movement itself may be said to date from its establishment in 1907. By this statement there is no desire to detract from the great value of the work accomplished by such organizations as the national, state and local civil service reform leagues, and the 


\section{INTRODUCTION}

National Municipal League. These organizations, however. differ radically in character, organization and methods of work from those which it is our purpose to consider, and of which the New York Bureau of Municipal Research is a leading example. Their function has been primarily educational. They have had no permanent staff, and no funds with which to prosecute detailed investigations of conditions obtaining in particular governments or particular branches of government. It is greatly to their credit that, within the limits of their resources, they have not only criticized existing conditions but have pointed out the direction which reform should take. Only in small degree, however, have they been able to formulate the specific means by which the reforms advocated were to be put into execution.

The establishment of the Bureau of Municipal Research of New York marks an epoch in the movement for governmental reform in the United States. Organized originally for the purpose of making a critical study of the administration of the public affairs of the city of New York with a view to pointing out how that administration might be put upon a more efficient, honest and economical basis, it became a great center for the inauguration of similar undertakings throughout the country. To its direct influence may be traced not only the organization of similar bureaus in Philadelphia, Cincinnati, Pittsburgh, Baltimore and many other cities, and the establishment of the Institute for Government Research at Washington, D. C., but the creation of other public and private agencies which have for their purpose the investigation of methods of administration of particular governments or particular services, and, on the basis of such investigation, the formulation of concrete, constructive measures of reform.

So rapidly did the movement for citizen agencies extend itself, and so numerous did these agencies become, that there was formed in 1916 a National Federation of Governmental Research Agencies-since called the Governmental Research Conference of the United States and Canada-having for its purpose "the better interchange of experience" and "the discussion of municipal and research problems" by such agen-

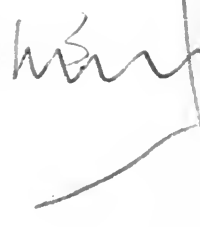




\section{EFFORTS FOR ADMINISTRATIVE REFORM}

cies. This organization has held annual meetings in I9I 7 and I9I $8 .{ }^{1}$

The principle underlying all of these undertakings is that if results of importance are to be accomplished, the government or service to be inquired into must be put upon the operating table, dissected and studied in its minutest detail of structure, function and procedure. Not until a thorough knowledge is had of existing conditions can effective proposals for change be brought forward. Every such proposal must have back of it a convincing showing of existing defects. Thorough investigation of existing conditions is thus the keynote of the new method. The making of such investigations requires a definite organization, adequate funds and a trained personnel.

Bureaus of municipal research are purely private undertakings. Their success naturally raised the question as to the desirability of governments, instead of waiting upon private initiative, themselves bringing into existence services through which their organization, activities and methods of business might be subjected to searching criticism. This idea was first taken up by certain cities. Boston established its Finance Commission in 1907, Chicago, its Commission on City Expenditures in 1909, and Milwaukee, its Bureau of Economy

${ }^{1}$ At the 1917 meeting the Bureau of Government of the Department of Political Science of the University of Michigan was designated to act as a central office or clearing house for the conference and thus to furnish the means for putting into effect the several measures for coöperative work that had been decided upon. This office since April, I918, has issued a monthly bulletin, intended solely for circulation among the member agencies, giving the work in progress by each of the member research agencies and the work completed since the preceding issue.

The proceedings of the conference have largely been of an informal character, though a certain number of formal papers have been presented. No published report of the proceedings has, however, been made.

The conference is supported by the annual membership fees of \$15 required of each member agency, of \$10 required of academic bureaus of government research, and $\$ 5$ required of individuals elected as associate members. Only member agencies, however, have the right to vote and participate in the direction of the conference's affairs.

The office of the Secretary and Treasurer is No. 25 Main Street, East Rochester, New York; and that of the central office and library, Law Building, University of Michigan, Ann Arbor, Michigan. 


\section{INTRODUCTION}

and Efficiency in I9II. This phase of the movement received its real impetus, however, through the establishment by the national government in I9Io of what was known as "The President's Commission on Economy and Efficiency." The commission received this designation since funds for its establishment were voted by Congress at the request of President Taft, were placed at his complete disposal, and were by him devoted to the establishment and support of a commission to which the above name was given. This lead of the United States government was speedily followed by the governments of a number of states.

In the foregoing we have considered only the work of services having for their specific object the investigation and reform of particular governments. Important as is their work they represent but one phase of the modern movement for governmental efficiency. In many other directions the spirit of this new movement is manifest. Many services of our government without waiting for the establishment of formal commissions or bureaus have entered upon the work of selfanalysis and improvement. In particular have great improvements been effected in the offices of comptrollers and other financial officers in the field of public accounting. Municipal reference libraries have sprung into existence, the resources of which are available both to the general student and to the officials of the cities in which they are located. Chambers of commerce, boards of trade and like organizations have given an attention to the improvement of governmental conditions such as they have never displayed in the past. National associations have been created for the purpose of studying problems of administration in particular fields. Among these special mention should be made of the National Association of Comptrollers and Accounting Officers, and the Association of American Government Accountants. The proceedings and publications of these organizations are contributing greatly both to the spread of knowledge regarding the technical problems of administration and the promotion of actual reforms. Finally, the universities of the land have been quick to respond to the new spirit. This has been manifested in a number of ways. The fundamental courses on politics and government have been given a much more practical character than 


\section{EFFORTS FOR ADMINISTRATIVE REFORM}

they previously had. New courses dealing directly with problems of administration have been added, and graduate students in politics have been encouraged to make their researches in the field of administration. A significant feature of this changed attitude is the willingness which universities have shown to have the members of their faculties and their graduate students coöperate directly in governmental research enterprises. Perhaps the most extensive undertaking in this direction is the creation of the Training School for Public Service conducted under the auspices of the Bureau of Municipal Research of New York City, which began operations in I9 I I, and the attempt to devise plans by which graduate students in the departments of politics and economics of universities generally may be attached to government services to the double end that the government may receive the advantage of their services and that the students themselves may receive a practical education in the administration of public affairs. The whole movement has gone far enough in some instances as to presage the conversion of graduate departments into departments of research analogous to those maintained by the department of the natural sciences. Whatever the outcome the universities will certainly perform the function of training schools for the public service to an extent never attempted by them in the past.

Reverting from these varied expressions of the newer interest in public administration to the agencies specifically organized for research, which it is our particular purpose to consider, it may be of value to outline the various forms of organization and method which may be employed by such. agencies, both official and private.

A government desiring to improve its methods of administration may proceed in any one or more of the following ways :

I. The whole work of investigation and reform may be left to the individual services; or

2. The chief executive may, on his own initiative or in pursuance of special authority conferred upon him by the legislature, proceed to an investigation and reform of governmental organization and methods generally; or

3. The legislature itself may undertake this work. 


\section{INTRODUCTION}

The first of these methods may be said to be one which, in a certain sense, is always in operation. There are few services which do not currently make more or less of an effort to improve their methods of administration. What is here meant is something different from this. We have in mind the case where a government becomes persuaded that its organization and methods of business are faulty, and the several services are charged with the duty of making a special inquiry into their organization and administrative procedure, with the view of making such improvements as lie within their power and of recommending such action on the part of other authorities as in their opinion is necessary in order to accomplish reforms, the taking of action in reference to which lies outside of the scope of their authority.

The advantages of this method are that responsibility for action is thrown directly upon the services involved, that the work will be performed by persons thoroughly familiar with the conditions, needs and problems to be met, and that the work may be prosecuted at a minimum of expense. Opposed to these obvious advantages are, however, certain disadvantages which tend to set a definite limit to the good results that may be expected from this method. First among these is the psychological factor that it is difficult to secure from officers a frank acknowledgment of either their official shortcomings or those of the services for the conduct of which they are responsible. In all such inquiries the services are in a way put upon the defensive. There is a strong tendency for officers and employees alike to defend the methods that they have been employing. Officers are naturally reluctant to criticize the acts of their associates and employees are still more reluctant to criticize those of their superiors. Secondly, though the persons making the investigation may be familiar with the methods investigated, they are not likely to be familiar with other methods. An officer may be convinced that the methods followed by his service are thoroughly satisfactory because he is in ignorance of other methods by which the same character of work can be more efficiently performed.

The task of improving governmental conditions is to too great an extent looked upon as one of ferreting out imperfections. It is of equal importance to discover superior meth- 
ods with a view to having them generally adopted when applicable. This end cannot well be attained when each service concerns itself with its own affairs only. Finally, there is a great field of reform into which this method can penetrate to but a slight extent. In no small degree existing defects in administrative methods are due to a faulty organization of the administrative branch of the government as a whole. Services are not properly correlated. Instead of constituting parts of one highly integrated piece of administrative mechanism, they occupy more or less independent positions. Power is not logically distributed. There are too often overlapping of authority and duplication of organization, plant, personnel and work. The remedying of these imperfections is wholly beyond the power of the services acting independently and concerning themselves with their own methods and problems only.

We have taken some pains to point out the limitations of this method since the tendency has been so strong in the past to rely upon it as a means for bringing about reforms. It is not for a moment questioned that great good can be accomplished by its employment, and that a certain use should be made of it. At the same time it is well to realize that really important and fundamental reforms cannot be accomplished through its utilization alone.

The other two methods of self-investigation and reform by a government, that where the investigation is prosecuted by the chief executive and that where it is made by the legislature, are not open to the objections to which we have directed attention. Both contemplate an entire survey of the organization, activities and methods of the government. If properly organized and conducted there is no reason why the most far-reaching results in the way of reform may not be accomplished by either of these methods. To secure such results certain things, if not essential, are at. least of great importance. If experience is to be any guide it may be asserted that valuable results may be expected only where a special body, bureau, board or commission is created for the undertaking of the work, where adequate funds are placed at its disposition for defraying the necessary expenses of the undertaking, where the personnel and staff of this body are 


\section{INTRODUCTION}

wholly or in large part composed of persons having no other official connection with the government under investigation, and where these persons are selected for their special competence in respect to the work entrusted to them. These requirements are essential since the whole object of the investigation is to secure expert, non-partisan criticism of existing conditions and proposals for change. The men making the investigation must thus not only have technical knowledge and experience in reference to the matters inquired into by them, but be in a position where they can make their criticisms and suggestions with the utmost independence and fearlessness. It is not contended that valuable results cannot be accomplished by a board composed of members of the legislature or administrative officials, but there is far less likelihood of this being the case than where use is made of any economy and efficiency bureau or commission composed of persons holding no other official position and selected with special reference to their qualifications for the work. Furthermore, it is only by employing persons outside of the government that knowledge regarding approved methods in force may be brought to bear upon the work in hand.

At this point the exceedingly important question is presented as to which of the two methods of investigation, that under the auspices and general direction of the legislature or that under the auspices and general direction of the chief executive, is the preferable one. Most of the official economy and efficiency commissions that have been created during the period under consideration have been of the latter character. Though their establishment was authorized and the funds for their support were voted by the legislature, provision was in most cases made that their personnel should be selected by the chief executive, and that they should work under the general direction of and report to that officer. From a legal standpoint the inquiry was thus one made by the chief executive, the commission being but the agency through which he performed this duty. Generally, when the recommendations made by the commission required no legislation, the chief executive and his associates could put them into force or not according as they commended themselves to their judgment. When legislative action was required it was the duty of the 


\section{EFFORTS FOR ADMINISTRATIVE REFORM}

chief executive to transmit the reports of the commission to the legislature with such approval or disapproval of these recommendations as he deemed proper. This was the character of the President's Commission on Economy and Efficiency, and, as stated, the prevailing character of most of the other official economy and efficiency commissions that have been established during recent years.

Though the executive type of inquiry is the one which has thus commended itself to most governments which have taken any action at all, it is important to note that the legislative type is much the most logical, and, in some respects, from the theoretical standpoint at least, the most desirable form of procedure. The legislature, under our form of government, is the organ exercising the function of direction, supervision, and control. From the standpoint of administration, the chief executive and all administrative officers are but the agents of the legislature through which the determinations of the latter are carried out. Logically, therefore, it is the legislature which, as principal, should from time to time institute such investigations as are necessary in order to assure itself that its agents are performing their duties in an efficient and economical manner. Furthermore, as the source of all administrative authority, upon it primarily falls the duty of determining all large matters of organization and procedure, or of insuring that all delegated authority is properly exercised.

To these theoretical considerations may be added the practical one that, when an inquiry is prosecuted under legislative auspices, the chances of having the reforms recommended adopted are much enhanced. The unfortunate friction and strained relations between the legislature and the executive, which seems to be such a feature of our government, makes it difficult for the executive to secure the adoption of proposals emanating from him. The most disheartening feature of the work of all official economy and efficiency commissions is the extent to which their recommendations have not only failed of adoption, but have failed of even receiving serious consideration. There must be some reason for this. In the opinion of the writer, one explanation at least of this phenomenon is to be found in the source from which the requests for action emanate. Were the recommendations made 


\section{INTRODUCTION}

by an organ of the legislature itself, it is but reasonable to assume that they would be received more favorably and would secure serious consideration and partial, if not full, adoption.

To these advantages of the legislative over the executive inquiry, but one counter disadvantage can be opposed. This disadvantage is the purely practical one of the difficulty of securing a thoroughly non-partisan and independent investigation if conducted under legislative auspices. Aside from any deliberate intent on the part of the legislature to use the investigation for party purposes, there is presented the question of the selection of the directing personnel and employees of the investigative body with a reference solely to their qualifications for the work. It is certain that any such body will be subjected to constant pressure on the part of members of the legislature to give employment to their protégés. It would seem to the writer that it should be possible to provide adequate safeguards against these evils. One device would be that of appropriating the funds necessary for the entire investigation, instead of voting funds from session to session, and of giving complete independence to the members of the commission by providing that their tenure of office should be that of the life of the commission, and that their compensation should not be changed during such time.

In this connection it is important to note that if results of importance are to be expected a number of years will be required for the prosecution of the work. Five years will be none too long a period. If the work is worth doing at all it is worth doing thoroughly. The investigation of existing conditions should be pushed to the minutest details of organization and procedure, an undertaking involving the expenditure of much time and labor. The real necessity for adequate time, however, lies in the fact that it is much more desirable that the work shall be prosecuted by a small, highly-paid, expert staff, which will take up one or two problems of administration at a time for detailed study and report, than to attempt to investigate all phases at the same time with a large and less efficient force. If this question of keeping politics and personal considerations out of the work of the commission can be successfully met, there is more chance of positive reform being actually accomplished through a legisla- 


\section{EFFORTS FOR ADMINISTRATIVE REFORM}

tive than through an executive investigation. If it cannot be, then the latter type of inquiry should be preferred.

From a consideration of the official type of investigation, we now turn to an examination of the alternative type, that where the work of inquiry and the formulation of reform proposals are undertaken by a purely private organization, such as is best illustrated by the Institute for Government Research and bureaus of municipal research. Here the organization problems of the official research agency, just discussed, are of course absent. In their place there is found, however, a problem perhaps more perplexing-the question of the attitude which the investigative bureau should take towards the government to be investigated and its officers. In meeting this delicate question two alternative lines of action lie open to it, that of attack and that of coöperation. If it chooses the first, it will devote itself to making an exposé of existing bad conditions, and by a publicity campaign and the pressure of public opinion seek to force the effecting of improvements. If it elects the second, it will devote itself no less actively to seeking to determine existing imperfections, but, instead of using the information so obtained as a means of formulating a public indictment of the government and its administration, it will bring the facts so established to the authorities interested, together with its suggestions regarding the steps that are required in order to bring about a better condition of affairs. Constructive proposals for reform and actual lines of action will thus be worked out in the closest possible coöperation with the authorities upon whom falls the responsibility for recommending or taking action. Only when the authorities stubbornly refuse to coöperate in the work or give due consideration to the bureau's proposals is resort had to power of public opinion by making a plain statement of conditions as revealed by the investigations of the bureau.

It cannot be too emphatically stated that the second of these two policies, that of working in the closest possible cooperation with the officers of the government under investigation, is the one that should, if possible, be followed. The bureau should keep steadily in mind that its purpose is not to indict but to improve. The first should be looked upon 


\section{INTRODUCTION}

as but the means to the second, which is the end in view. This means that in many cases it may be advisable to give no publicity to either the facts found to exist or to the suggestions as formulated by the bureau. Often it is desirable to have it appear that the reforms have been put through, if not originated, by the services affected. The bureau can well afford to forego the pleasure of popular recognition of its work, if its end is attained. In point of fact the services effecting the reform are usually quite willing in their administrative reports to give due recognition to the assistance that they have received from the bureau in bringing about improved conditions, and this recognition can be given publicity by the bureau if it desires to do so.

If this policy is not only adopted by the bureau, but the fact clearly brought home to the officers of the government investigated that this is the policy, and that all statements of facts and proposals will be brought to their attention and an opportunity given to them to act upon them before any publicity is had, there will usually be little difficulty in establishing cordial coöperative relations between the officers of the bureau and the governments. It is very much to the credit of the bureaus of municipal research that have been established that this important consideration has been clearly seen and acted upon, and to it must be attributed in no small degree the'success that has followed their efforts. ${ }^{1}$

An important point in connection with the adoption of this policy should here be mentioned. This is that it is desirable that, as far as possible, the bureau shall be so financed that it is not under the necessity of making a general appeal to the public for funds with which to carry on its, work. If such a necessity exists, it will be under a constant incentive to exploit its achievements, and this may be precisely what it is desirable that it should not do. A very considerable difference of opinion has arisen between persons connected with, or interested in, the work of these organizations, regarding the attitude that the bureau should take towards the general public. There is a very strong tendency for these bureaus to look upon themselves as agencies for the education of the

${ }^{1}$ For a fuller discussion of this question of policy see chapter on The Institute for Government Research. 


\section{EFFORTS FOR ADMINISTRATIVE REFORM}

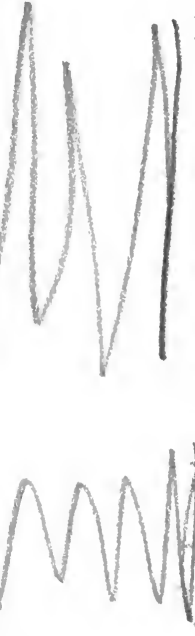

public in respect to governmental matters, and for the stimulation of popular interest in public affairs. The theory upon which this action rests is that an aroused public appreciation of the gravity of existing evils and of the efficacy of proposed measures of reform will force action by those responsible for the conduct of public affairs. No one can question the desirability of the public having a knowledge of existing conditions or of actively interesting itself in the work of reform. At the same time it is very much a question whether bureaus of governmental research should undertake this work. If they do they should do so with great caution. In respect to it the general principle may be laid down that they should make their efforts take the form of seeking popullar support for measures desired by the administration, rather than of criticism and attack upon the latter. There are many desirable things which one administration would like to do, but which it cannot accomplish as a result of popular indifference to its work. In respect to these, bureaus of governmental research can do much by aiding in the arousing of public opinion. Here, as in its work proper, the bureau should thus seek to work in coöperation with, rather than in antagonism to, the authorities in power.

If a citizen agency adopts toward the official the attitude recommended, it will not be likely to encounter much difficulty in its endeavors to get from official sources the information which it needs as the basis of its work. Few governments have been willing to take the position that they would antagonize a public-spirited enterprise of this sort. In fact, in the great majority of cases the authorities have indorsed, if they have not actually participated in, the inauguration of the undertaking and have coöperated cordially in its work.

Nevertheless it must be admitted that even with a cooperative attitude on the part of officials, the unofficial agency will rarely find itself quite as favorably sithated as is the official agency for securing the information which it must have regarding existing conditions and practices if a firm basis for criticism and constructive proposals is to be laid, and for the taking of direct action toward the adoption of such $/$ proposals. It remains, therefore, to consider for what reasons, if 


\section{INTRODUCTION}

any, the creation of unofficial research agencies may be justified.

Resort to this method of action may be justified by two considerations. The first, and most obvious, of these is that governments generally have failed on their own initiative and through their own efforts to bring about that reform of their organization and methods which it is the right of their citizens to demand of them. It is both the interest and the duty of all persons to do all in their power to secure an improvement in governmental conditions, and failing the display of sufficient vigor by the official government in this direction, it is logical for citizens to organize unofficial effort for the purpose.

It is not necessary, however, for advocates of this method to rely upon this justification. Examination will show that the unofficial agency has certain important advantages which fully warrant resort to it under almost any conditions. Briefly stated, they consist in the facts: that the work can be organized and conducted as an absolutely independent, nonpartisan, purely public-spirited and scientific undertaking; that it can be placed upon a permanent basis or at least given such a lease of life as will enable it to perform its work deliberately and thoroughly; that nothing stands in the way of, but on the contrary every inducement exists for, the selection of the personnel to have charge of the work with sole reference to their technical and other qualifications for the work; and that, if properly managed, its recommendations can get a popular support not otherwise obtainable. Receiving its impulse from the outside rather than from the inside of the government investigated, the unofficial agency represents the effort to bring to bear upon the government the adoption of those principles of organization and administration which are employed by the most efficient of other bodies, public and private.

Of great interest in this connection are the following extracts from the resolutions adopted in 1916 by the National Federation of Governmental Research Agencies (now the Governmental Research Conference) which has been mentioned above: 


\section{EFFORTS FOR ADMINISTRATIVE REFORM}

That, while appreciating the value of efficiency movements which are a part of commercial organizations, educational institutions, and governmental units, we believe citizens' agencies for public efficiency to be most effective when independently organized and administered as regards finance, methods, publicity and other fundamental policies.

That it is prejudicial to the best interests of citizens' agencies for public efficiency for members of boards or trustees to seek or hold public office or employment, to promote the candidacy of political candidates, or to be vitally concerned in city contracts or franchises.

Whether the unofficial research agency has a permanent place in our public life, or whether it represents a passing phase of the movement for the improvement of public administration is a question which it is not yet possible to answer; nor is it necessary to do so. No one who is familiar with the current situation in the field of public administration can doubt that for some years to come the unofficial agency will find a large and growing sphere of usefulness. 


\section{PART I}

AGENCIES FOR RESEARCH IN GOVERNMENT 



\section{CHAPTER I}

AGENCIES FOR STUDYING PUBLIC ADMINISTRATION GENERALLY : UNOFFICIAL

Agencies for research in governmental administration usually owe their creation to the desire to improve the administration of a particular government. There has consequently been established thus far but one agency for research in public administration generally - the-Institute for Government Research, located at Washington, D. C. In fact even this organization, as is set forth below, regards the national government as more particularly within its sphere of interest than are state and local governments, but as its program also embraces the study of public administration generally, including matters of state and local administration, it has been deemed appropriate to treat it as falling under a different head from those official agencies, of which account is given in the following chapter, which have been or are concerned solely with the national administration.

The following account of the Institute for Government Research consists of a reproduction of a paper presented by the Director of the Institute, Mr. W. F. Willoughby, at the annual meeting of the American Political Science Association in December, I9I7. ${ }^{1}$

The Institute for Government Research is an institution incorporated under the laws of the District of Columbia and wholly supported by voluntary private donations. It received its charter on March I3, 1916, and began active operations on October I of the same year. Its purpose as set forth in its charter is :

To conduct scientific investigations into the theory and practice of governmental administration, including inquiries

${ }^{1}$ Printed in American Political Science Review, February, 1918, vol. I2, p. 49. 


\section{EFFORTS FOR ADMINISTRATIVE REFORM}

into the form of organization and the manner of operation of federal, state and local governmental bodies and offices in the United States of America; the powers, duties, limitations and qualifications of officers; the methods of administration employed; the character and cost of results obtained and the conditions affecting the efficiency and welfare of governmental officers and employees; to carry on such inquiries, directly or with the coöperation of governments, learned societies, institutions of learning or other agencies and individuals and to make public the results of its investigations; to maintain a library for the use of the society or its members and officers and those affiliated with its work; and to prosecute such other inquiries and perform such other services as may tend to the development and application of the principles of efficiency in governmental administration.

There are certain features of this statement of the purposes of the Institute to which it is desired to direct attention. The first of these is that the Institute is declared to be an institution for scientific research. Its establishment represents the conviction on the part of its founders that the work of administration is, if not a science, a subject to the study of which the scientific method should be rigidly applied. It recognizes that, though the problems of administration are of great complexity and vary with the conditions under which each operation of government is carried on, there are certain fundamental principles and practices which must obtain in all governmental undertakings, if efficiency and economy in operation are to be secured.

Thus, for example, if we apply to the problem of administration the scientific method of analysis, it will be found that it is resolvable into five fairly distinguishable parts : problems of organization, problems of personnel, problems of material, problems of business practice and procedure, and problems of finance. Each of these, in turn, is resolvable into more special phases. For example, problems of personnel have to do with the recruitment of personnel, how employees shall be classified, the basis on which their compensation shall be fixed, the manner of determining their efficiency through the establishment of efficiency records or otherwise, and the system of promotions based thereon, what shall be the work- 


\section{PUBLIC ADMINISTRATION GENERALLY}

ing conditions of employees in respect to such matters as permanency of tenure, hours of labor, leave privileges, etc., and finally, the provision that shall be made in the way of retirement allowances or pensions for those incapacitated while in the performance of their duties or as the result of age. In like manner, problems of finance include such questions as the system of handling and disbursing funds, of accounting and reporting, of audit and, most important of all, of determining and making provision for the revenue and expenditure needs of the several services and of the government as a whole, or, to use the expression now commonly used, of the budgetary system that shall be employed.

One of the major activities of the Institute will thus be that of subjecting this whole subject of public administration to scientific analysis, and of seeking to determine and make known the principles and practices that should be followed in respect to each of these general and specific activities in order to secure efficiency and economy in operation. In the performance of this activity the Institute has already made substantial progress. It has inaugurated a series of volumes, which is now in course of publication, under the general title of "Principles of Administration." The first volumes of this series, entitled Principles Governing the Retirement of Public Employees and Principles of Government Purchasing have already been published.

It is contemplated, through these and other projected volumes, to cover in time the whole field of administration as outlined above. ${ }^{1}$

Emphasis has been laid at the outset upon this function of the Institute, since it is important to show that, while the Institute has, in many respects, the same field of operations as bureaus of municipal research, economy and efficiency commissions, and like bodies, and like them aims to contribute

${ }^{1}$ It is only proper to state that the performance of this branch of the Institute's work has been much facilitated by the generous grant of something over $\$ 100,000$ made by the Rockefeller Foundation, prior to the establishment of the Institute, for the prosecution of studies of this character. The expenditure of this fund was entrusted to a committee of which the writer was a member. The committee requested Dr. F. A. Cleveland to assume general editorial direction of the studies. On the establishment of the Institute the results of these studies were in great part turned over to it. 
directly to securing specific reforms in methods of governmental organization and administration, its operations will extend beyond those which such bodies usually undertake, or which, indeed, it is feasible for them to attempt.

Correlative with this attempt to determine and make known the most approved principles of administration, the Institute plans to subject to detailed and critical study those systems of administration, whether in this or foreign countries, the practices and experiences of which it believes will be of most value to our own governments in seeking to put their systems of administration upon a more efficient basis. It is evident, for example, that it would be of value to the United States government, in working out its problems of income tax administration, or of customs or postal administration, to have a knowledge of how these problems have been handled in other countries. In like manner it is desirable, if one service of the government has devised an especially efficient system for the performance of a particular category of work, such for example as the purchase, custody and issue of supplies, that this system should be described in published form so that a knowledge of it may be available to other services.

A second feature of the Institute's program will, therefore, be to make investigations with this end in view. The results of these investigations will be published in a series of volumes under the general title "Studies in Administration." At the present time the most important problem of administration confronting both our national and state governments is that of devising and installing a proper budgetary system. The Institute has accordingly selected this subject as the first problem of administration for intensive study, and the first three volumes in its "Studies in Administration" relate to this subject. In the first is given a description of the system of financial administration of Great Britain, the country which has the oldest and foremost budgetary system in the world. In the second is given a translation of René Stourm's notable work on the budget, which gives an excellent and detailed account of the French budgetary system. In the third is given a study of the Canadian budgetary system, prepared along the lines of the volume on the British system. This 


\section{PUBLIC ADMINISTRATION GENERALLY}

volume has the special value of showing how the British system works, and in important respects fails to work satisfactorily, under conditions different from those that prevail in the mother country and somewhat analogous to those prevailing in the United States.

The Institute has in preparation three other volumes, which it is expected will appear shortly, entitled The System of Financial Administration of the United States, The Movement for Budgetary Reform in the States, ${ }^{1}$ and The Problem of a National Budget. ${ }^{1}$ The last volume, in addition to giving an analysis of the problem as it presents itself to the national government, points out the steps that will have to be taken by that government in putting itself upon a proper budgetary basis. These volumes, it is believed, will furnish information which cannot fail to be of value in the movement now in full swing for the adoption of a budgetary system by all of our governing bodies.

Here again it will be noted that the work of the Institute goes beyond that of bureaus of municipal research and economy and efficiency commissions. These organizations necessarily confine their attention almost wholly to the operations of a particular government; and, in doing so, address themselves primarily to those features of administration which in their opinion are most in need of reform. The Institute, in this branch of its work, studies problems of administration of any government whose system or experience is likely to throw light upon problems confronting our own government, and selects for study those systems which it believes to be most efficient rather than the reverse.

A third feature of the work of the Institute that can be of great value to the cause of administrative reform in the United States is that of acting as a general clearing house, or organ, through which the large number of agencies now engaged in promoting administrative reform in the United States may keep in touch with, and make use of, one another's work. To this end the Institute now has in preparation a volume which will appear in its series of "Studies in Administration," entitled Organized Efforts for the Improvement of Methods of Administration in the United States. In this vol-

Since published. 
ume the attempt will be made to give an account of the history, organization and work of such agencies as official economy and efficiency commissions, bureaus of municipal research, legislative reference and bill-drafting services, municipal reference libraries, and the like.

In this connection, it may also be stated, that the Institute is seeking to build up at its headquarters in Washington as complete a technical library of material bearing upon problems of administration in the United States as it is feasible for it to secure. Especially is it making the effort to secure complete sets of the publications of the agencies just mentioned, of the reports of special legislative and other investigations and other literature of a like character which it is difficult to find in ordinary libraries. This library is in charge of a trained librarian and no pains are being spared to classify and index the material received in such a way that it may be readily utilized. It is hardly necessary to say that the facilities of this library are open to all students of political science.

While the Institute will thus, as an institution for scientific research, occupy the whole field of public administration, it will have a special field which it plans to cultivate intensively. One, if not the main, motive of the founders of the Institute was to bring into existence an organization that would do for the national government what bureaus of municipal research and similar bodies were so effectively doing for many of the municipalities and states of the country. It was rightly felt that, just as the operations of this government were of a magnitude and importance vastly greater than those of any state or city, its activities of a far more varied character, and its problems of administration of an infinitely more complex nature, so the need was greater that they should be subjected to study with a view to making known the conditions to be confronted and the means to be employed in meeting them.

As President Taft expressed it in his message to Congress of January I7, I9I2, in referring to the inquiry being made under his, direction into the efficiency and economy of the methods of prosecuting public business, the activities of the national government "are almost as varied as those of the 


\section{PUBLIC ADMINISTRATION GENERALLY}

entire business world. The operations of the government affect the interest of every person living within the jurisdiction of the United States. Its organization embraces stations and centers of work located in every city and in many local subdivisions of the country. Its gross expenditures amount to nearly $\$ \mathrm{I}, \mathrm{COO}, 000,000$ annually. Including the personnel of the military and naval establishments, more than 400,000 persons are required to do the work imposed by law upon the executive branch of the government. This vast organization has never been studied in detail as one piece of administrative mechanism. Never have the foundations been laid for a thorough consideration of the relations of all of its parts. No comprehensive effort has been made to list its multifarious activities or to group them in such a way as to present a clear picture of what the government is doing. Never has a complete description been given of the agencies through which these activities are performed. At no time has the attempt been made to study all of these activities and agencies with a view to the assignment of each activity to the agency best fitted for its performance, to the avoidance of duplication of plant and work, to the integration of all administrative agencies of the government, so far as may be practicable, into a unified organization for the most effective and economical dispatch of public business."

If this was the condition prior to our entrance into the present great world conflict, it needs no great powers of imagination to conceive conditions as they exist at the present time, and, in no small measure, will continue to exist after the war is closed. Not only has it been necessary enormously to expand the operations of existing services and to throw upon them work for which they were never intended, but scores of new agencies have had to be hastily constructed with but inadequate consideration of the forms of organization that should be given to them or the relations that they should bear to one another. Unless administrative confusion is to reign supreme after the war, it is imperative that the whole administrative machinery of the government shall, as it were, be put upon the operating table for the purpose of determining what changes should be made in it, with a view to so distributing the work to be done among the several agencies em- 


\section{EFFORTS FOR ADMINISTRATIVE REFORM}

ployed, and of so correlating these several parts as to make of them one unified system of administrative mechanism.

This is a work which cannot be done by the services themselves acting independently. It must be performed by some agency which will approach the study from the objective standpoint, and have in mind the welfare of the government as a whole. The work moreover must be prosecuted systematically to the end that each service will be subjected to the same character of examination and that, as far as possible, the proposals for reform will have consistency, will look to the erection of the services into a logically integrated piece of administrative machinery, and result in the unification and standardization of business practices and procedure. For the performance of such a work the Institute, granted that it has adequate funds for the purpose, is admirably equipped; and has already vigorously entered upon its execution.

The first step in an undertaking of this character is to obtain a complete and thorough knowledge of existing conditions. To this end the Institute has undertaken, as one of its major activities, the preparation of a series of monographs in which will be given a detailed description of each of the fifty or more distinct services of the government. These monographs will all be prepared according to a uniform plan. They will give: first, the history of the establishment and development of the service; second, not merely its general functions, but its specific activities; third, its organization for the handling of these activities; fourth, the character of its plant; fifth, a compilation of, or reference to, the laws and regulations governing its operations; sixth, statistical statements showing its appropriations, expenditures and other data for a period of years; and, finally, a full bibliography of the sources of information, official and private, descriptive of the service and its operations. These monographs, as completed, will be published in a series of volumes under the general title "Service Monographs of the United States Government." 1

In the preparation of these monographs the Institute has steadily in mind, and aims to produce, documents that will be

${ }^{1}$ The first two numbers of this series, covering the U. S. Reclamation Service and the U. S. Geological Survey, have since been publishẹd. 


\section{PUBLIC ADMINISTRATION GENERALLY}

not only of interest to the general public, but of direct value and assistance in the administration of public affairs. To executive officials they will offer valuable tools of administration. Through them such officers can, with a minimum of effort, inform themselves regarding the details, not only of their own services, but of those with whose facilities, activities, and methods it is desirable that they should be familiar. Under present conditions services frequently engage in activities in ignorance of the fact that the work projected has already been done, or is in process of execution, by others. Many cases exist where one service can make effective use of the organization, plant or results of other services if it has knowledge that such facilities are in existence. With the constant shifting of directing personnel that takes place in the administrative branch of the national government, the existence of means by which incoming officials may thus readily secure information regarding their own and other services is a matter of prime importance.

To members of Congress these monographs should prove of no less value. At present congressmen are called upon to legislate and appropriate money for services concerning whose needs and real problems they can secure but imperfect information. That the possession by each member of a set of monographs, such as is here projected, prepared according to a uniform plan, will be a great aid to intelligent legislation and appropriation of funds, can hardly be questioned.

To the public, finally, these monographs will give that knowledge of the organization and operations of their government which they must have if they are properly to exercise their function of bringing to bear an enlightened public opinion upon the conduct of governmental affairs.

One further fact regarding these studies should be noted. While they will make no direct recommendations in the direction of reform, they will furnish the data which must be available if really important reforms are to be accomplished, and they cannot fail greatly to stimulate efforts in this direction. Prepared as they will be according to a uniform plan, and setting forth, as they will, the activities, plant, organization, personnel and laws governing the several services of the government, they will automatically reveal the manner in which 
the activities of the government are distributed among the several services, the extent to which work in the same field is being performed by different services, and thus furnish the information that is essential to a consideration of the great question of the better distribution and coördination of activities among the several departments, establishments and bureaus, and the extent to which duplications of plant, organization and work may be eliminated. They will, in a word, permit of that comprehensive and intensive study of the administrative branch of the government as a whole which has never before been possible. To recapitulate, they will serve the double purpose of furnishing an essential tool for efficient legislation, administration and popular control, and of laying the basis for critical and constructive work on the part of those upon whom responsibility for action in this way primarily rests.

Though emphasis has thus been placed upon the work of the Institute in the way of making known conditions as a basis for critical and constructive studies, the latter field will by no means be neglected by the Institute. Progressively, as it secures the data, it contemplates taking up, one after another, the great problems of administration as they confront the national government, and seeking, by their study, to indicate ways in which they can be more efficiently and economically handled.

Its service monographs, for example, will make known that the national government now possesses three distinct services, located in different departments, having for their purpose the making of hydrographic surveys and the preparation of sailing charts and directions: the coast and geodetic survey, the hydrographic office in the Navy Department, and the lakes survey service in the War Department. Manifestly there is here raised the question whether it is not desirable that the work of these three services should be done by a single service.

This is but an illustration of the many questions regarding the possible more effective grouping of services and distribution of duties that will arise. No one of them can be properly answered without a detailed knowledge of the organization and duties of existing services. There is here pre- 
sented a wide field of inquiry into which the Institute will, as information is accumulated, enter.

In the foregoing we have sought to make known what may be termed the fundamental or basic work program of the Institute. The prosecution of this work, however, represents but one phase of its activities. A second phase, and one which at the present time is very prominent, lies in the direct coöperation of the Institute with services of the national government in their efforts to work out the special problems of administration now confronting them. This phase of the Institute's work is excellently stated in the printed notice, given to the public at the time of its establishment, when the Institute was described to be "an association of citizens for cooperating with public officials in the scientific study of business methods with a view to promoting efficiency in government and advancing the science of administration."

It is evident that, if the Institute is to serve its full measure of usefulness, it should not only work in close and cordial relations with government officials, but be accepted by the latter as an organization that can be of direct assistance to them. No efforts have been spared by the Institute to establish its relations with the services of the government upon this basis. That its efforts in this direction have been successful is made evident both by the willingness on the part of such services to furnish to the Institute the information needed by it for the prosecution of its studies, and by the numerous requests that have been made by them upon the Institute for assistance.

In point of fact considerably more than half of the work done by the Institute since its establishment has been in meeting calls of this character. On the entrance of our country into the war, the Institute, in common with many other organizations, offered its services to the government. This offer was accepted, and the Institute has done a large amount of work for such organizations as the Council of National Defense, the American National Red Cross, and various bureaus and services of the War Department. Requests for its assistance, however, have not come exclusively from the military services. It has had no small number of requests for 
assistance from purely civil branches of the government. These calls indeed have been greater than the financial resources of the Institute have permitted it to meet. To such an extent is this true that it may be stated that the opportunity for the Institute to render assistance in this way, and thus to contribute directly to making the administration of national affairs more efficient, is only limited by the financial resources that it can command.

The success of the Institute in establishing cordial working relations with the national government must be attributed primarily to the fundamental policy adopted by it in respect to all of its work. This policy consists in taking the position that responsibility for effecting reforms rests primarily upon government officials themselves, that all an outside organization, such as the Institute, can do is to render such assistance as it can to such officials, and that to the latter should accrue the credit for improvements made.

This question of the policy to be pursued by the Institute in performing its work was rightly considered by the trustees as one of supreme importance and a matter that should be definitely determined before any operations were begun. The writer of the present paper, prior to his appointment as director of the Institute, was accordingly requested to submit his views regarding this matter. This he did in a memorandum, which received the full endorsement of the trustees, from which the following may be quoted:

An organization such as the Institute can proceed in two ways in seeking the improvement of governmental conditions. It can operate as a scientific body having for its purpose to assist government officials in effecting reform, or it can make of itself an agent for bringing public pressure to bear upon officials for the purpose of compelling them to take action believed to be desirable. In the opinion of the writer it is of the utmost importance that the first of these two methods should be adopted. This means that the policy of the Institute should be that of working in the closest and most cordial relations with government officials that it is possible to secure. No effort should be spared to make officials of the government understand that what is sought is to aid them to improve conditions; that the actual effecting of reforms 


\section{PUBLIC ADMINISTRATION GENERALLY}

should be their work; and that to them should accrue official and public credit for reforms accomplished. The Institute itself should as far as possible keep in the background. . . As elsewhere stated, the Institute and the board of trustees should be satisfied if as the result of their efforts, results are being accomplished. The extent to which they get any public credit for such results should be a matter of indifference to them.

Action upon the foregoing policy does not of course preclude the making and publication of scientific studies in the field of administration, such as we have described above, nor the preparation and publication of reports dealing with those general problems of administration, such as the formulation of a proper budgetary system, the better correlation of existing services departmentally, and the standardization of business practices and procedure. It does not deny, moreover, the value of the work done by organizations having for their avowed purpose the public indictment of present conditions and the conduct of a public propaganda for the introduction of specific measures of reform. It merely means that it is unwise for the same organization to attempt to ride these two horses at the same time.

The question is wholly one of method. The Institute, no less than other organizations, will reach definite opinions regarding what changes should be made in methods of organization and administration in order to make them more efficient and economical, and will seek no less strenuously to have these changes effected; but it will do so, as far as possible, by seeking to convince those charged with the conduct of public affairs of their desirability, and having them take the necessary steps for their accomplishment. That greater results in the long run can be secured in this way than by seeking to have reforms forced upon officials over their opposition, is the firm conviction of the officers of the Institute. Even where seeming success follows the latter method the results are often more apparent than real. Few administrative practices, no matter what their theoretical merits, will give good results unless those responsible for their operation are persuaded of their desirability and apply them in good faith. Many re- 
forms, such as the introduction of cost keeping systems, have met with shipwreck for this reason.

For over thirty years the writer has been intimately concerned in one capacity or another with the administrative work of the national government. It is his experience that the directing personnel at Washington-the heads of departments, bureaus and divisions - are of a high order of ability and genuinely desirous of having their services efficiently organized and conducted. If they have fallen short of achieving their aims in many respects this is due to the fact that each officer is concerned with the administration of but one service, that he has not been in a position where he can consider problems of administration from the standpoint of the government as a whole, and that the demands upon him for the performance of the current work of his service are such as to leave him little or no time for the study of methods of administration practiced elsewhere, or to work out new principles and practices for himself. The experience of the Institute but confirms past experience that these officials are freely receptive to suggested improvements and welcome assistance when given to them in the proper way and spirit. With such a condition of affairs, it would be the height of folly not to assume a like sympathetic attitude and make the fullest possible use of this good will.

In concluding this account of the Institute for Government Research, it is not out of place to point out how closely its aims correspond to those of the American Political Science Association, and how nearly it meets a desire formally expressed by it. In 1908 this association addressed to the Carnegie Institution a letter and memorial pointing out the need for the establishment at Washington of a department of research in political science and suggesting that that institution take steps in that direction. In the establishment of the Institute for Government Research the association sees its wishes in great part accomplished. Though the Institute has apparently as its field but one branch of political science, that of administration, that field, properly construed, is of broad scope. Efficient administration depends in no small degree upon the existence of a proper political organization and the application of proper political practices. It cannot be achieved without 


\section{PUBLIC ADMINISTRATION GENERALLY}

due regard to these larger questions of political science. On the other hand, the aim of all political science is a good administration of public affairs. "The government best administered," writes Alexander Pope, "is best." In a way, therefore, the study of administration means but the study of political science or government from a certain standpoint, that of adaptation of forms and means to an end, efficiency in operation.

\section{PUBLICATIONS}

Studies in Administration.

The system of financial administration of Great Britain, a report by William F. Willoughby, Westel W. Willoughby, Samuel McCune Lindsay. New York, D. Appleton and Company, 1917. XVI, $362 \mathrm{p}$.

The budget, by René Stourm; a translation from the seventh edition of Le budget... Thaddeus Plazinski, translator ... New York, D. Appleton and Company, I9I7. XXVII, 6I9 p.

The Canadian budgetary system, by Harold G. Villard and W. W. Willoughby. New York, D. Appleton and Company, 19I8. XIII, $379 \mathrm{p}$.

The problem of a national budget, by William Franklin Willoughby. New York, D. Appleton and Company, 1918. XIII, 220 p.

The movement for budgetary reform in the states, by William Franklin Willoughby. New York, D. Appleton and Company, I9I8. XI, $254 \mathrm{p}$.

Teachers pension systems in the United States: a critical and descriptive study, by Paul Studensky. New York, D. Appletor and Company, I9I9.

Organized efforts for the improvement of methods of administration in the United States, by Gustavus A. Weber. New York, D. Appleton and Company, 1919. 37I p.

Principles of Administration.

Principles governing the retirement of public employees, by Lewis Meriam. New York, D. Appleton and Company, I9I8. XXX, $477 \mathrm{p}$.

Principles of government purchasing, by Arthur G. Thomas. New York, D. Appleton and Company, 1919. XIII, $275 \mathrm{p}$.

Service Monographs of the United States.

I. The U.S. geological survey. New York, D. Appleton and Company, 1919. X, I63 p.

2. The U. S. reclamation service. New York, D. Appleton and Company, I9I9. XI, I77 p. 


\section{CHAPTER II}

\section{AGENCIES FOR INVESTIGATING THE NATIONAL ADMINISTRATION : OFFICIAL}

Official inquiries into the conduct of business in the executive departments of the national government have been made from time to time since the beginning of the government. These inquiries have been made under various auspices, by order of bureau chiefs, of heads of departments, of the President and of Congress itself. They range in scope from inquiries into special details of administrative practice to general investigations of the organization and business practices of the executive departments.

It is manifestly impracticable even to list, much less to describe in detail, all such inquiries, many of which indeed are recorded only in manuscripts filed in the bureaus or departments to which they relate. Little useful purpose, moreover, would be served by attempting to do so, since most of them relate to conditions which have now passed away. There is reproduced in the following section, however, a list of congressional inquiries into the conduct of the business of the executive departments, I789 to I9II, which was prepared by the late President's Commission on Economy and Efficiency and published by it as a part of its report on The Need for a National Budget. ${ }^{1}$ This list is by no means a complete enumeration of official reports dealing with the organization and methods of business of the administrative branch of the government. It does serve to indicate, however, the leading investigations of a general character that have been made during this period at the special direction of Congress.

Of these, two are of such comparatively recent date and of such general importance that it has been thought desirable

${ }^{1}$ House Doc. No. 851, 62d Congress, 2d Session, I912. 
to give a special account of them. Reference is had to the investigation of the methods of business and work in the executive departments made by a select committee of the Senate, of which Mr. Cockrell was chairman, in I887-1889, and to the investigation into the status of the laws organizing the executive departments, their methods of business, etc., made by a joint commission composed of members of the two Houses, of which Mr. Cockrell and Mr. Dockery were the representatives, in $1893-1895$.

Following these two investigations two other inquiries of a general character into the organization and business methods of the departments were made under the direct control of the President. The first of these, known as the Keep Commission Inquiry, was undertaken by the President upon his own initiative and without special sanction of Congress. The results of its work which extended over the years 1905 to 1909 were only in small part embodied in printed reports and even these reports are almost unobtainable since they were not issued as public documents. The second inquiry was also undertaken at the instance of the President but was authorized by Congress through the grant of funds for its prosecution. This inquiry was conducted by a special body, known as the President's Commission on Economy and Efficiency, which the President created and whose activities covered the period I9Io to I9I 3.

Finally, in I9I3, Congress made provision for a permanent service, which later was given the designation of United States Bureau of Efficiency, to have the duty of making inquiries into the organization and business methods of the administrative services with a view to their improvement.

The work of these five bodies is of such importance and bears so directly upon present day problems, that it has been thought desirable to give a separate description of each.

Bibliography of Congressional Inquiries into the Conduct of the Business of Executive Departments Other Than by Standing Committees of Congress, r 789-19r r. ${ }^{1}$ The follow-

${ }^{1}$ Reproduced from The Need for a National Budget. Report of the President's Commission on Economy and Efficiency, H. Doc. 85I, 62d Cong., 2d Sess., I9I2. 


\section{EFFORTS FOR ADMINISTRATIVE REFORM}

ing bibliography contains references to the reports of all committees, commissions, and individuals directed by congressional act or resolution to inquire or report upon any phase of administration within the executive departments. The classification is made according to inquiries of a general character and those dealing with a specific department or bureau. Within these divisions the arrangement is chronological. The period covered dates from I789 to I9I I.

The sources consulted were:

American State Papers.

Descriptive catalogue of Government Publications, I789-i88i.

Poore, Ben: Perley, Wash., I885.

Congressional documents-

Index compiled under L. C. Ferrell, I789-1893.

Congressional Record-

House reports.

House documents.

Senate reports.

Senate documents.

United States statutes.

Estimates of appropriations.

Receipts and disbursements.

An effort has been made to include the cost of each inquiry and where appropriation was made the amount has been noted. Where the expenses were published in "Receipts and disbursements" these, too, have been listed. Often there appears in "Receipts and disbursements," for those inquiries whose expenses were to be paid out of money not otherwise appropriated, no specific entry. Presumably the disbursement is included in the item under Senate and House disbursements "Expenses for special and select committees."

GENERAL

Expenditures of the executive departments.-(5th Cong., 2d sess. H. Rept. I36. American State Papers, Finance: Vol. I, 590. Wash., I798.) Report of committee appointed to inquire and report on possible necessary changes in methods of distributing public moneys appropriated for each department.

Conduct of clerks and officers in various departments.-(I5th 


\section{AGENCIES FOR NATIONAL ADMINISTRATION}

Cong., Ist sess. H. Rept. 182. Ser. No. II. Wash., 1818.) Inquiry into conduct in office of clerks in several departments. Committee appointed upon-House resolution.

Retrenchment in public expenditures. - (I7th Cong., Ist sess. $\mathrm{H}$. Rept. 645. American State Papers, Finance: Vol. III, 80o. Wash., 1822.) Report of select committee appointed to inquire whether any part of public expenditure may be retrenched.

Expenditures of public departments.-(2oth Cong., Ist sess. H. Rept. I I6. Ser. No. I77. Wash., I828.) Committee on Public Expenditures, through resolution of the House, reports on compatibility with other work of special examination into appropriations, disbursements, and vouchers received for public money.

Retrenching the expenses of the Government.-(20th Cong., Ist sess. H. Rept. 922. American State Papers, Finance: Vol. V, Io49. Wash., I828.) Report of select committee appointed under House resolution to inquire into and report any possible retrenchment in the expenses of the Government.

Reorganizing the executize departments.-(2Ist Cong., Ist sess. S. Rept. I09. Ser. No. I93. Wash., I830.) Report of select committee to whom was referred part of President's message respecting reorganization of the departments.

Public expenditures.-(27th Cong., 2d sess. H. Rept. 458. Ser. No. 408. Wash., 1842.) Report by Committee on Public Expenditures, explaining impossibility of carrying on such detailed work as examination of appropriations, disbursements, etc., would entail.

Retrenchment-Reorganization of the executive departments.(27th Cong., 2d sess. H. Rept. 74I. Ser. No. 4IO. Wash., I842.) Select committee of five Members to examine as to number of employees, expenditures, and mode of business in several departments and possible curtailment in civil list.

Civil service.-(44th Cong., Ist sess. S. Rept. 289. Ser. No. I667. Wash., 1876.) Report by select committee appointed by Senate to examine several branches of civil service with a view to reorganization. Report contains correspondence with heads of departments.

Expenses investigation.-(47th Cong., Ist sess. S. Rept. 265. Ser. No. 2005. Wash., I882.) Report of Committee on Appropriations authorized by Senate resolution to investigate expenditure, methods, and costs of disbursing appropriations.

Methods of business in the executve departments.- (5oth Cong., Ist sess. S. Rept. 507. Ser. No. 2521. Wash., 1888.) Report from select committee (Mr. Cockrell) in response to Senate resolution creating same to inquire into methods of business in executive departments. Allowance for clerk hire and other necessary expenses from contingent fund of the Senate. (Expenses for special and select committees amounted in 1888 to $\$ 31,153.31$.)

Executive departments, organization, etc. - 53 d Cong., Ist sess. H. Rept. 49. Ser. No. 3158. Wash., 1893.) Report by Mr. Dockery from the joint commission to inquire into the status of the laws organizing the executive departments. Commission created under legislative, executive, and judicial appropriation act March 3, I893. Organization and conduct of business were main lines of inquiry. Expenses to be paid out of any money in Treasury not otherwise accounted for. Disbursements were as follows: 


\section{EFFORTS FOR ADMINISTRATIVE REFORM}

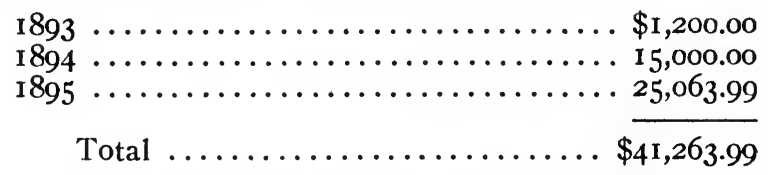

Annual settlement of public accounts. - (53d Cong., 2d sess. S. Misc. Doc. I53. Ser. No. 317I. Wash., 1894.). Joint report from Secretaries of departments in re annual settlements of public accounts December 6, 1816 A departmental inquiry by each Secretary was necessitated by this demand from the Senate for reports.

Government officers and employees.-(6rst Cong., 3d sess. S. Doc. 836. Wash., I9II.) Message from President transmitting in reply to Senate resolution information in re total number of appointments by President, with and without senatorial confirmation; total number of officers and employees under civil-service rules; total number of employees subject to removal by President without congressional action; total number of officers and employees of the United States exclusive of Army and Navy officers.

\section{STATE}

Expenditures in the State Department-(25th Cong., 2d sess. H. Rept. 931. Ser. No. 336. Wash., 1838.) Investigation by Committee on Expenditures in the State Department into legality of method of accounting for, and proper disbursement of funds appropriated to use of department.

Employees, etc., in the State Department--(29th Cong., Ist sess. H. Rept. 552. Ser. No. 490. Wash., 1846.) Committee of the Judiciary inquire into the number and duties of employees and growth of force comparative with that of 28 years previous to 1846 .

Changes in the law of the State Department.-(46th Cong., 3d sess. S. Ex. Doc. 53. Ser. No. 1943. Wash., I88I.) Response of Secretary in answer to Senate resolution in re desirable changes in laws regulating management of the department.

Methods of business in the executive departments.-(See "General." Wash., I888.)

Executive departments, organization, etc.-(See "General." Wash., 1893.)

Consular Service.-(53d Cong., 3d sess. S. Rept. 886. Ser. No. 3289. Wash., I895.) Report by Mr. Morgan, Committee on Foreign Relations, submitting views on condition of service, reforms necessary, and methods to bring them about.

Ages, etc., of employees in Department of State--(57th Cong., Ist sess. S. Doc. 65. Ser. No. 4226. Wash., 1901.) Response of Secretary in answer to Senate resolution calling for information.

Fraud in public service, select committee on appropriations for the employees engaged in detection and prevention of.-(6oth Cong., 2 d sess. H. Rept. 2320. Ser. No. 5387. Wash., 1909.) Report of select committee in response to House resolution calling for an investigation.

\section{TREASURY}

Condition of the Treasury Department.-( $3 \mathrm{~d}$ Cong., Ist sess. H. Rept. 68. American State Papers, Finance, Vol. I, 28I. Wash, 


\section{AGENCIES FOR NATIONAL ADMINISTRATION}

I794.) Report of a committee appointed to examine the state of the Treasury Department generally, and to report on methods of accounting in the Department of the Treasury.

Condition of the Treasury.-(6th Cong., 2d sess. H. Rept. I57. American Statc Papers, Finance, Vol. I, 690. Wash., I80I.) Report of comnlittee instructed by House to investigate conduct of affairs in the department.

Unsettled balances.-( I4th Cong., Ist sess. H. Rept. 486. American State Papers, Finance, Vol. III, I23. Wash., I8I6.) Report of committee in response to House resolution calling for an investigation into subject.

Reorganization of the Treasury Department.-(25th Cong., 2d sess. H. Rept. 81. Ser. No. 333. Wash., I837.) Report of the Committee on Commerce.

Treasury Department.-(38th Cong., Ist sess. H. Rept. I40. Ser. No. I207. Wash., I864.) Report of select committee appointed by the House to inquire into conduct of business in Treasury.

United States securities.-(40th Cong., 3d sess. S. Rept. 273. Ser. No. I362. Wash., I869.) Report of joint select committee on retrenchment on Treasury methods of printing and guarding securities of United States. Expenditures, \$3,948.84.

Contracts in the Treasury Department.-(4Ist Cong., 3d sess. H. Rept. 5I, Ser. No. 1464. Wash., I87I.) Report of Committee on Expenditures on Public Buildings upon House resolution ordering an investigation of administration of Supervising Architect.

Accounts of the Treasury Department.-(44th Cong., Ist sess. S. Rept. 37I. Ser. No. I668. Wash., I876.) Report by Committee on Finance upon Senate resolution to investigate books and accounts of Treasury.

Investigation of accounts of the Treasury Department.-(46th Cong., 2d sess. S. Rept. 539. Ser. No. I897. Wash., I880.) On Senate resolution, a committee of five were appointed to investigate the finance reports, books, and accounts of the Treasury Department. Two experts at $\$ 6$ per diem paid from contingent fund of Senate.

Bureau of Engraving and Printing.-(5Ist Cong., Ist sess. S. Ex. Doc. I75. Ser. No. 2688. Wash., I890.) Response of Secretary of Treasury in answer to Senate resolution calling for information relative to expenditures and amount of work performed in the Bureau of Engraving and Printing.

Methods of business in the executive departments.-(See "General." Wash., I888.)

Conduct of the Office of the Supervising Architect.-(.5Ist Cong., $2 d$ sess. S. Rept. 26I5. Ser. No. 2828. Wash., I89I.) Inquiry by Committee on Public Buildings and Grounds into conduct of Supervising Architect's Office.

Executive departments, organization, etc.-(See "General." Wash., 1893.)

Secret Service, inquiry into.-(6oth Cong., 2d sess. S. Rept. 970. Ser. No. 5383. Wash., I909.) Report of Committee on Appropriations in response to Senate resolution ordering an inquiry into conduct of bureau. 


\section{EFFORTS FOR ADMINISTRATIVE REFORM}

WAR

Reorganization of the Quartermaster's Department.-( I 8th Cong., 2d sess. H. Rept. 4. Ser. No. I22. Wash., I824.) Inquiry by Committee on Military Affairs upon resolution of the House report and bill on reorganization.

Coast Survey.-(27th Cong., 3d sess. H. Rept. r.7o. Ser. No. 427. Wash., I843.) Report by Select Committee on Coast Survey and of Weights and Measures, concluding with testimony. Opinions of $\mathrm{Mr}$. Ayerigg, who reported, are unfavorable to methods and accomplishment of the survey. (See also Mr. Mallory's report, 2 ; th Cong., 3d sess. H. Rept. 43. Wash., I 843.)

Superintendent of national armories.-(33d Cong., Ist sess. $H$. Misc. Doc. 76. Ser. No. 74I. Wash., I854.) Testimony before select committee of the Senate to inquire and report whether appointment of military officers to superintend construction of lighthouses, works of river and harbor improvement, etc., is compatible with public interest. General inquiry into management of business of public works.

Expenditures in the War Department.-(42d Cong., $3 \mathrm{~d}$ sess. $\mathrm{H}$. Rept. 87. Ser. No. I 576. Wash., I873.) Committee on Expenditures directed by House resolution to inquire whether expenditures are justified by law, vouchers retained, necessary machinery for better accountancy of public money, how best to retrench, what offices and services may be discontinued.

Management of the War Department.-(44th Cong., Ist sess. H. Rept. 799. Ser. No. I7I 5. Wash., I876.) Inquiry by committee into management of affairs.

Reorganization of the Army.- (45th Cong., 3d sess. S. Rept. 555. Ser. No. I837. Wash., I878.) Report of joint committee on reorganization. Created by act of Congress. Expenditures, \$5,232.67.

Efficiency of the several departments.-(46th Cong., 3d sess. S. Ex. Doc. 20. Ser. No. I94I. Wash., I881.) Letter from Secretary of War in response to Senate resolution directing the Secretaries of State, War, Navy, and Interior Departments, Postmaster General, and Attorney General to report necessary changes in legislation to promote efficiency and economy.

Methods of buininess in the executive departments.-(See "General." Wash., i 888.)

Executive departments, organization, etc.-(See "General." Wash., I 893.)

Buildings rented by the War Department.- (58th Cong., 2 d sess. S. Doc. IOI. Ser. No. 4588. Wash., I904.) Reply of Secretary to Senate resolution directing the transmission to the Senate of a statement of quarters and buildings rented by War Department.

\section{JUSTICE}

Management of the Department of Justice.-(46th Cong., $3 \mathrm{~d}$ sess. S. Ex. Doc. I. Ser. No. I94I. Wash., I880.) Letter from Attorney General in response to resolution calling for recommendations from heads of departments concerning possible necessary changes in laws regulating the management of the departments. 


\section{AGENCIES FOR NATIONAL ADMINISTRATION}

Methods of business in the executive departments.-(See "General." Wash., I 888 .)

Executive departments, organization, etc.-(See "General." Wash., I893.)

\section{POST OFFICE}

Affairs of the Post Office Department.-(16th Cong., 2d sess. H. Rept. 65. Ser. No. 57. Wash., I821.) Investigation by select committee in re expenditure, contracts, and accounting methods.

Post Office affairs.-(I7th Cong., Ist sess. H. Rept. I04. Ser. No. 71. Wash., 1822.) Report of select committee on fiscal affairs of the Post Office.

Post Office Department.-(21st Cong., 2d sess. S. Rept. 73. Ser. No. 204. Wash., I83I.) Report of committee appointed in pursuance of Senate resolution on administration, personnel, and general management of the department.

Examination of the Post Office Department.-(23d Cong., $2 \mathrm{~d}$ sess. H. Rept. 103. Ser. No. 277. Wash., 1835.) Report of select committee appointed under House resolution to examine condition and proceedings of the department. Main inquiry was financial.

Post Office Department.-(24th Cong., Ist sess. S. Doc. 289. Ser. No. 282. Wash., 1836.) Report of the accountants engaged to examine the accounts of the Post Office.

Changes of law affecting the Post Office Department.-(46th Cong., 3d sess. S. Ex. Doc. I6. Ser. No. I94I. Wash., I88I.) Response of Postmaster General to Senate resolution in re desirable changes in laws affecting management of the department.

Railway Mail Service.-(48th Cong., Ist sess. H. Ex. Doc. 35 Ser. No. 2196. Wash., 1884.) Report of commission appointed by Postmaster General in compliance with act of Congress on a system for gauging rates of pay for carrying the mails on railroad routes.

Methods of business in the executive departments.-(See "General." Wash., I 888.)

Executive departments, organization, etc.-(See "General." Wash., 1893.)

Postal service.- (56th Cong., 2d sess. S. Doc. 89. Ser. Nos. 4036, 4037, 4038. 3 vols. Wash., 1901.) Report of joint commission appointed by congressional act to inquire into prices paid for mail transportation and postal service generally. Appropriations:

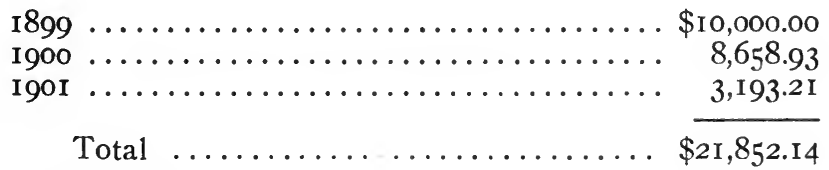

Ocean mail scrvice, accounts paid for.-( 57 th Cong., Ist sess. S. Doc. 87. Ser. No. 4226. Wash., 1902.) Report of Postmaster General in response to Senate resolution calling for information in re contracts for ocean mail service.

Business methods of the post office.-(6oth Cong., Ist sess. S. Rept. 20I. Ser. No. 522I. Wash., I908.) Preliminary report of the 


\section{EFFORTS FOR ADMINISTRATIVE REFORM}

joint commission authorized by Congress to investigate business system of the post office. For final report see Ser. No. 538r. Expenditures:

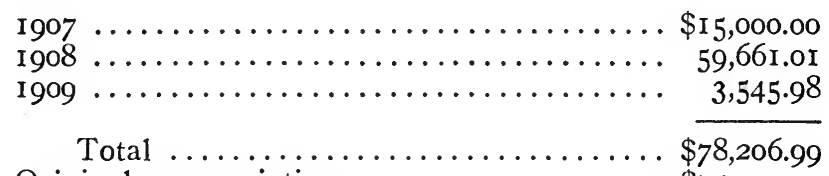

Original appropriation $\ldots \ldots \ldots \ldots \ldots \ldots \ldots 75,000.00$

Military and naval expenditures.-( 5 th Cong., $2 \mathrm{~d}$ sess. H. Rept. 123. American State Papers, Finance; Vol. I, 507. Wash., I798.) Report by Secretary of the Treasury in answer to House resolution requiring information in re sums advanced for military matters, accounts of quartermasters, etc.

Expenditures in the Navy Department.-(16th Cong., 2d sess. $\mathrm{H}$. Rept. 67. Ser. No. 57. Wash., I82I.) An explanation of impossibility of regular committee carrying on special investigation into business of department.

Marine hospitals.-(26th Cong., Ist sess. S. Rept. 8. Ser. No. 354. Wash., 1839.) Reply of Secretary of Treasury in answer to House resolution in re expediency of a change in system of marine hospitals.

Reorganization-Navy.-(27th Cong., 2d sess. H. Doc. I67. Ser. No. 404. Wash., 1842.) Report on reorganization by Secretary of Navy in answer to House resolution calling for same. (See also "Report of Secretary of Navy," 26th Cong., Ist sess. H. Doc. 39. Ser. No. 364. Wash., I839.)

Marine engines.-(38th Cong., $2 \mathrm{~d}$ sess. H. Rept. 8. Ser. No. I235. Wash., 1865.) By House resolution Committee on Naval Affairs report on structure, inferior speed, and authorization of new marine engines.

Charges against the Navy Department.-(42d Cong., $2 \mathrm{~d}$ sess. H. Misc. Doc. 20I. Ser. No. I527. Wash., I872.) Select committee appointed by Speaker to report evidence and opinions as to administration of affairs and business methods in the Navy Department. (See also Mr. Sargent's Report, 42d Cong., 2d sess. H. Rept. 80. Ser. No. I542. Wash., I872.)

Reduction of navy yards and navy hospitals.-(43d Cong., $2 \mathrm{~d}$ sess. S. Rept. 565. Ser. No. 1632. Wash., 1875.) Report of Committee on Naval Affairs instructed to inquire into expediency of reducing the number of navy yards and naval hospitals on Atlantic coast.

Investigation of the Navy Department.-(44th Cong., Ist sess. H. Rept. 784. Ser. No. I7I2. Wash., I876.) By order of House resolution, Committee on Naval Affairs reports on use and purchase of material in the Navy Department.

Contracts of the Navy Department.- (45th Cong., 2d sess. $\mathrm{H}$. Rept. 787. Ser. No. I825. Wash., 1878.) Inquiry by Committee on Expenditures in the Navy. Department in response to order of 


\section{AGENCIES FOR NATIONAL ADMINISTRATION}

the House into expenditures, receipts, debt, and claims against the department.

Investigation of the Navy Department.- (45th Cong., 3d sess. H. Rept. II2. Ser. No. I866. Wash., I879.) By House resolution Committee on Naval Affairs reports on condition of administration, presence of abuses or frauds, and proposes necessary changes.

Organization of certain bureaus. - (49th Cong., Ist sess. S. Rept. 1285. Ser. No. 2361. Wash., 1886.) Report of joint commission on present organization of Signal Service, Geological Survey, Coast and Geodetic Survey, and the Hydrographic Office of the Navy Department. Aimed to secure greater efficiency and economy of administration.

Methods of business in the executive departments.-(See "General." Wash., I888.)

Executive departments, organization, etc.-(See "General." Wash., I893.)

Personnel of the Nav'y.-(53d Cong., Ist sess. H. Rept. I22. Ser. No. 3157. Wash., I893.) Reports from Committee on Naval Affairs. Report concerns possible improvement of personnel and methods of promotion. (See also H. Rept. 1573, 53d Cong., 3d sess. Ser. No. 3345. Wash., 1895.)

Total cost of persomnel of Navy.- (55th Cong., $3 \mathrm{~d}$ sess. S. Doc. I15. Ser. No. 3735. Wash., I899.) Report of Secretary in response to Senate resolution inquiring into cost of Navy personnel.

Ages, etc., of employees in Navy Department.- (57th Cong., Ist sess. S. Doc. 66. Ser. No. 4226. Wash., 1901.) Response of Secretary in answer to Senate resolution calling for information in re employees.

Staff Corps increase.-(57th Cong., Ist sess. S. Doc. 395. Ser. No. 4245. Wash., 1902.) At instance of several bureau heads Committee on Naval Affairs held hearings to inquire into need of additional staff force.

Navy yards, board to investigate administration of (Recommendation of passage of H. J. Res. 239 authorizing appointment of such a board.) - (59th Cong. H. Rept. 8org, vol. 2.) Do not find board was appointed.

Contracts for armor plate.-Letter from Secretary of Navy in re cancelling of contract with Midvale Co.- (58th Cong., $3 \mathrm{~d}$ sess. H. Doc. 35I, vol. 53. Ser. No. 4832. Wash., 1905.) Report of Secretary in response to House Resolution calling for information.

Methods of business and expenditures in Navy Department, inquiry into.-(6oth Cong. S. Doc. 693, vol. 21. Ser. No. 5408. Wash., 1909.) Statement of Secretary before Committee on Naval Affairs instructed by Senate resolution to inquire into business methods in department.

\section{INTERIOR}

Condition of the General Land Office.-(47th Cong., Ist sess. S. Rept. 362. Ser. No. 2006. Wash., 1882.) Report from Committee on Public Lands in response to Senate resolution authorizing an investigation into conditions under which employees are working, possible improvements, and correction of existing abuses in administration. 


\section{EFFORTS FOR ADMINISTRATIVE REFORM}

Geological Survey.-(49th Cong., Ist sess. H. Rept. 22I4. Ser. No. 244I. Wash., I886.) Report from Commission on Signal Service, Geological Survey, etc., recommending the restriction of publications and work of the Geological Survey. Expenses, \$1,490.50.

Pension Office investigation.-( $52 \mathrm{~d}$ Cong., Ist sess. H. Rept. I 868. Ser. No. 3049. Wash., I892.) Report of select committee of House under House resolution ordering an investigation and report on business methods of Pension Office.

Methods of business in the executive departments.-(See "General." Wash., 1888.)

Executive departments, organization, etc.-(See "General." Wash., I893.)

Employees, data in re employees of the Department of Interior. - (57th Cong., Ist sess. S. Doc. 66, vol. 8. Ser. No. 4226. Wash., 190I.) Report of Secretary in response to Senate resolution ordering an inquiry into facts and data concerning personnel of several departments.

Government Insane Hospital, administration and methods of conduct of.-( 59th Cong., 2 d sess. H. Rept. 7644. Ser. No. 5066. Wash., I907.) Report in two volumes by special committee appointed under House resolution ordering inquiry. Expenses to be paid from contingent fund of House.

Investigation of the Department of the Interior and of the Bureau of Forestry.-(6Ist Cong., 3d sess. S. Doc. 7I9. Ser. No. 5892. Wash., I9II.) Inquiry ordered by House joint resolution. Expenditures, I9I0, $\$ 20,000$; I9I I, $\$ 1,434.20$; total, $\$ 2$ I,434.20.

\section{AGRICULTURE}

Agriculture, repiort of the Commissioner of.-(40th Cong., 2d sess. H. Ex. Doc. 9I. Ser. No. I332. Wash., I868.) Response to House resolution instructing commissioner to report condition of department and legislation necessary to render department, through reorganization, efficient to carry on its work.

Agriculture, Department of.-( 43 d Cong., $2 \mathrm{~d}$ sess. H. Rept. I35. Ser. No. I657. Wash., 1875.) Inquiry by Committee on Agriculture into work and personnel of department.

Methods of business in the exccutive departments.-(See "General." Wash., I888.)

Executive departments, organization, etc.-(See "General." Wash., 1893.)

Forestry incestigations and work of the Department of Agriculturc.-(55th Cong., 3 d sess. H. Doc. I8I. Ser. No. 38r 3. Wash., 1899.) In act appropriating for Department of Agriculture it was ordered that the Secretary report on the investigations in forestry and the progress of work in the Department of Agriculture.

Expenditures in the Department of Agriculture.-(59th Cong., 2d sess. H. Rept. 8147. Ser. No. 5065. Wash., 1907.) Inquiry by the Committee on Expenditures into business of accounting in the department.

Agriculture-Employees. - (57th Cong., Ist sess. S. Doc. 24 , vol. 2. Ser. No. 4220. Wash., I90I.) Data in re employees of the Department of Agriculture. 


\section{AGENCIES FOR NATIONAL ADMINISTRATION}

Accounting system in the Department of Agriculture.-(59th Cong., 2d sess. H. Rept. 8I47, vol. 2. Wash., I906.)

\section{COMMERCE AND LABOR}

Investigation of United States Fish Commission.-(5Ist Cong., $2 \mathrm{~d}$ sess. S. Rept. 236I. Ser. No. 2828. Wash., I89I.) Report by subcommittee of the Senate Committee on Fish and Fisheries, on administration and morale of the commission.

Executive departments, organization, etc.-(See "General." Wash., I893.)

Permanent Census Bureau.-(52d Cong., 2d sess. H. Rept. 2393. Ser. No. 3I4I. Wash., I893.) Report of select committee to whom was referred the House resolution instructing them to inquire into expediency of establishing a permanent bureau. See also Senate Executive Document No. I, Fifty-second Congress, first session.

Immigration Service in San Francisco, investigation of.- (58th Cong., 3d sess. H. Doc. 166. Ser. No. 4830. Wash., I905.) Report of Secretary in response to act of Congress (sundry civil act).

Employees-Data in re employees in Department of Commerce and Labor.- (57th Cong., Ist sess. S. Doc. 23, vol. 2. Ser. No. 4220. Wash., I901.)

Bureau of Manufactures.-(59th Cong., Ist sess. S. Rept. 2748. Ser. No. 4905. Wash., I906.) Report by Committee on Manufactures upon amendment to House bill $\mathrm{I} 6472$, having to do with enlargement of the force in bureau. The committee have inquired into organization and needs of bureau and its needs for greater efficiency.

\section{GOVERNMENT PRINTING OFFICE}

Public printing.-(23d Cong., 2d sess. S. Rept. I22. Ser. No. 268. Wash., I8I9.) Report of joint committee recommending a plan for having the public printing done.

Public printing.- ( I 5 th Cong., 2d sess. S. Doc. 99. Ser. No. I5. Wash., I8I9.) Report by joint committee on subject of public printing and how it shall be carried on.

Public printing.-(26th Cong., Ist sess. H. Rept. 298. Ser. No. 370. Wash., I840.) Report of committee elected by the House to consider and investigate the subject of public printing as to just and reasonable compensation, etc. Contains minority report and answers to interrogations of the committee.

Public printing.-(27th Cong., 2d sess. S. Rept. 332. Ser. No. 398. Wash., I 842.) Report by Committee on Printing. Summarizes rather broadly previous investigations into costs, etc., connected with public printing.

Public printing.-(3Ist Cong., Ist sess. H. Misc. Doc. 55. Ser. No. 582. Wash., I850.) Report of select committee appointed by House to inquire into combination to break up contract system as regards public printing.

Public printing.-(36th Cong., Ist sess. H. Rept. 249. Ser. No. I068. Wash., I860.) Inquiry by Committee on Public Expenditures in response to House resolution instructing it to inquire into rates and fix just limits.

Public printing.-(40th Cong., 3d sess. S. Rept. 247. Ser. No. 


\section{EFFORTS FOR ADMINISTRATIVE REFORM}

1362. Wash., 1869.) Committee on Printing instructed by Senate to report on cost of each document issued annually by Government, possible curtailment of publications, and requisite changes in existing laws in re publication of United States laws.

Printing investigation.-(4Ist Cong., 2d sess. S. Rept. 264. Ser. No. I409. Wash., I870.) Report from Committee on Printing, directed by order of Senate to inquire into and report on certain charges of maladministration in the Printing Office. (See also H. Rept. 2740, 49th Cong., Ist sess. Ser. No. 2443. Wash., I886.)

Investigation of the Government Printing Office.-(44th Cong., ist sess. H. Rept. 495. Ser. No. I710. Wash., 1876.) In answer to House resolution, Committee on Printing investigate costs, economy in management, etc., in office.

Government Printing Office.- (45th Cong., 3d sess. H. Rept. I I9, Ser. No. 1867. Wash., I879.) Upon House resolution, Committee on Public Expenditures investigate and report on conduct of affairs in the Government Printing Office. Evidence, majority and minority reports included.

Public documents.-(47th Cong., 2d sess. H. Misc. Doc. 12. Ser. No. 2II5. Wash., I882.) Report by committee comprising superintendent of documents, Librarian of Congress, and Secretary of the Smithsonian Institution, under House resolution, asking for compilation of laws and regulations governing printing and distribution of documents and suggestions for economy.

Administration of the Government Printing Office.-(5oth Cong., Ist sess. H. Rept. 3300. Ser. No. 2608. Wash., 1888.) By resolution of House Committee on Printing was instructed to investigate administration of office, causes for delay, appointments and dismissals.

Methods of business in the executive departments.-(See "General." Wash., I888.)

Public printing.- (52d Cong., Ist sess. S. Rept. I8. Ser. No. 29II. Wash., I892.) An elaborate report by special committee of House on public printing and its management.

Executive departments, organization, etc.-(See "General." Wash.. 1893.)

Ages, etc., in Government Printing Office.-(57th Cong., Ist sess. S. Doc. 25. Ser. No. 4220. Wash., 1901.) Report of Public Printer in response to Senate resolution requesting data in re employees of office.

Cost of printing special edition of Congressional Record, investigation of.-(59th Cong., 2d sess. S. Doc. I08, vol. 3. Ser. No. 5070. Wash., I905:) Report of Public Printer in compliance with Senate resolution calling for information.

Printing Investigation Commission.-(6oth Cong., and following years. Wash., I905.) Report of select committee to inquire into condition of affairs in Printing Office and to suggest possible economies. The reports are numerous. Expenditures:

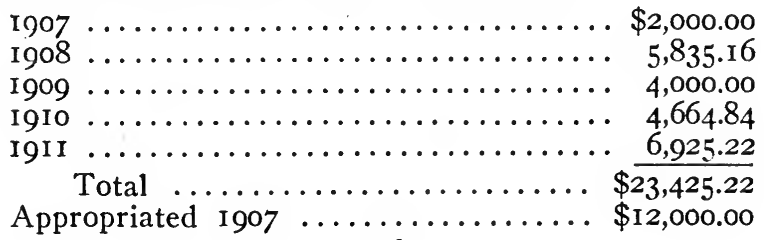


Select Committee on Methods of Business in the Executive Departments (Cockrell Committee) 1887-1889. On March 3, 1887, the Senate, on motion of Mr. Cockrell, passed the following resolution:

Resolved, That a select committee to consist of five Senators be, and the same is hereby, constituted and appointed, whose duty it shall be to inquire into and examine the methods of business and work in the Executive Departments of the Government, the time and attention devoted to the operations thereof by the persons employed therein, and generally to inquire into and report to the Senate the causes of the delays in transacting the public business said to exist in some of said Departments.

The committee was also authorized to employ a clerk and a stenographer and to send for persons and papers.

Messrs. Cockrell, Harris, Jones of Arkansas, Platt and Cullom were appointed as members of the select committee.

The passage of this resolution was the result of the widespread criticism of the delay that existed in many of the services of the government in the performance of their duties. Not a few bureaus were months and even years behind in their work. The feeling was very strong that this delay was only partially due to an inadequate force; that primarily it was due to archaic business methods and especially to the performance of much useless work.

The first step taken by the committee in the prosecution of the inquiry consisted in the sending of two letters to the heads of the departments, under date of March I8, I887, calling upon them to report regarding the condition of work within their departments and to supply data regarding their organization and business methods.

The first of these letters called for a detailed statement of the methods of transacting business in each division of each bureau of the department, "including one or more items of the principal business matters transacted in each of such divisions, beginning with the receipt of the business matter in the De- 


\section{EFFORTS FOR ADMINISTRATIVE REFORM}

partment, and then showing, in consecutive order, the various steps taken by each of such business matters through the various divisions" and the "employees through whose hands the same passes and by whom it is considered and acted upon, and the action thereon had and taken by each, till the same is finally disposed of and notice duly given to the proper party."

The other letter called for a detailed statement from each department and service, showing the amount and character of business in hand, pending and undisposed of, in each division on January I, I884, I885, I886, I887, and on March I, I887; the amount and character of business received, transacted and disposed of in each division; the average number of employees in each division during each month of the years I884, I885, I886 and I887 up to March I, I887, and the maximum and minimum amount of business transacted and disposed of by the employee doing the most and the employee doing the least in each division during each month of the period; the average number of days and the time and attention devoted to the consideration and transaction of business by the employees in each division and whether in person or by proxy, during each of the calendar years I 884 to I 886 and up to March, I887; and also the maximum and minimum number of days during each of those years so devoted to business by the employee in each division present for the greatest number of days and for the least number of days.

On March 23, I887, a third letter was sent to the same officials, which was not identical, but the purport of which was the same in each case, calling for a statement of the present legal organization of each department and the number and classes of officers and employees in, and the designation of, each bureau, division, station or other unit in and outside of Washington.

Finally, the committee caused certain items of business to be traced in consecutive order through the various steps taken from the beginning of action to the final consummation. These studies covered business matters originating in the Treasury Department and also in other departments and coming into the Treasury Department. The transactions selected were: the purchase of stationery for the use of the Treasury Department; an account for salary and fees of a United States consul; 
a requisition of a United States marshal for funds; an account of a United States marshal for fees and expenses; a district attorney's account for fees, etc. ; the accounts of a quartermaster of the United States Army for the fiscal year I885; an account of a receiver of public money at a local United States land office; and the adjustment and payment of a claim for quartermaster stores.

On the basis of the information secured by these means, Mr. Cockrell, on behalf of the committee, submitted to the Senate on March 8, I888, in addition to two minor bills, ${ }^{1}$ a report which was published as Senate Report No. 507, 5oth Congress, Ist Session. The report proper covered 272 pages, but attached to it were supporting statements, consisting chiefly of replies of the departments to letters of inquiry addressed to them, which occupied an additional 1900 pages.

This report more than substantiated the criticism that had been made against the administrative services in respect to their failure promptly to perform their work. For example, it was found that 39 employees, with salaries ranging from $\$ 720$ to $\$ 1,600$ per annum, were engaged, more or less, in copying, with pen and ink, the letter press copies of letters into record books. Cases of employees furnishing proxies or substitutes to perform their work at their salaries or at reduced compensations were found in three of the executive departments. On August 20, I887, there were in the General Land Office a total of 276,670 individual cases pending and undisposed of and I4,000 unanswered letters. There were 47,000 claims of soldiers, their widows and orphans, pending for acljustment before the Second Auditor. An engineer officer's request for approval of the employment of two pilots, one for $\$ 25$ and the other for $\$ 150$, in its course from the officer through the War Department, its return to that officer and its return again by him to the War Department, was handled by officers and clerks 76 times, and including messenger service, 94 times.

${ }^{1}$ One provided for continuing the work of classified abridgment of letters patent granted by the United States; the other authorized and provided for the disposition of useless papers in the executive departments. The latter was enacted February 16, i889. Mr. Cockrell also asked at the same time that the conmittee be continued the remainder of the session, which was done. 


\section{EFFORTS FOR ADMINISTRATIVE REFORM}

The following extracts from the report of the committee show in brief the conditions found as a result of their inquiries :

In the Treasury Department, the War Department and the Interior Department, and to a greater or less extent in other Departments, there are more briefings, notations, and record entries made, copying done, and record books kept than is necessary or requisite in preserving proper records of the transactions of the public business or as safeguards and checks against error, mistakes or frauds.

The items of business matters are required to pass through the hands of too many different officers and employees and through the hands of the same persons too often, thus causing the consumption of too much time in the disposition thereof and dividing the responsibility therefor among too many different employees. Some one clerk or employee, too often of the lower grades or classes as to salary, makes the examination and adjustment, and places his initials thereon, and all the others through whose hands the item of business may pass in its routine, act simply upon the faith of the initials so made by the one clerk or employee.

The committee reported that it could not undertake the labor and time necessary to investigate and determine all steps taken in the transaction of the multitudinous items of business matters coming before the various departments and to point out the steps in the present system which could be left out without detriment to accuracy and safety. It, therefore, recommended as the most feasible and practical remedy that the Secretaries of the Treasury and War Departments each appoint a commission to consider and revise the methods of business in his department.

In defining the duties of these proposed departmental commissions the select committee said:

This committee or commission in each Department should personally trace from inception to final disposition the various classes of public business therein transacted, and ascertain the exact number of persons, officers, or employees through whose hands the same passes, the time, attention and labor devoted thereto, the kind of work done thereto, and the entries and records made by each. With this data plainly and fully before 
them, and understood by them, they ought to be able to determine with certainty, safety and accuracy exactly what can be omitted, what is necessary to be added, and the safe and proper changes to be made, and then devise and prepare judicious, safe, and correct methods for the transaction of the various classes of public business, so that they can be finally disposed of with the greatest possible degree of correctness and promptness, and with the least possible labor, briefing, notating, and copying, and with the smallest number of record entries and record books, and by passing through as few different hands as possible, etc.

When they have completed their work and prepared the report thereof, they should then present the same to the Secretary appointing them, and if approved by him, or when corrected and approved by him, after full consultation, then the Secretary should cause the methods of business so determined upon to be strictly and rigidly carried out in every bureau and division of his Department, and hold the chiefs of bureaus and divisions to a strict accountability for the adoption and enforcement of such methods.

If it should be found that legislation is necessary to adopt or carry out the proposed methods, the requisite legislation should be proposed and submitted to Congress for consideration and action.

Letters were accordingly written by the chairman of the committee, on February IO, I888, to the Secretaries of War and of the Treasury. On March 20, I888, the Secretary of the Treasury appointed a commission consisting of the deputy first auditor and four division chiefs, and on March 22, I888, the Secretary of War appointed a board consisting of the chief clerk of the department, a division chief and a clerk to carry out the recommendations of the select committee.

The Treasury Commission took up the following subjects for investigation and report:

The Offices of the First, Second, Third and Fourth Auditors and First and Second Comptrollers, Commissioner of Customs, Register of the Treasury, and the Miscellaneous Division of the Secretary's Office; the warrant system; letter files; bond issues; files matter; fines, penalties, etc., placed in suit by collectors of customs; accounts of the Lighthouse Board; moneys appropriated for public building; sales of revenue-cutters and 
marine hospitals; settlement of the accounts of the Pacific railroads; accounts current of aided railway companies; overdue liabilities of quartermasters and paymasters; Indian claims; payment to employees in public buildings; presentation of duplicate vouchers; destruction of Treasury notes, etc.; last-sickness and burial claims; and proxies.

As a result of the recommendations made by this Treasury Commission, the Secretary of the Treasury caused the following important changes to be made: An entire change of the warrant system by which the number of warrants to be issued, signed, entered and checked is but little more than one-tenth the former number; a briefer and simpler method of recording accounts in the offices of the Second Comptroller and First Auditor, occupying about one-fourth of the time formerly required; a considerable diminution of the number of accounts by consolidating several of the same class into one report; the reduction of the bulk of certain accounts to onehalf their former size by discontinuing duplicate vouchers; the reduction of the bulk of certain stationery accounts to about one-third their size and greatly facilitating their settlement by the introduction of new forms; a simplification of some of the blanks used in the accounting offices and a discontinuance of others; a discontinuance of certain books of record by binding and preserving original papers which were copied in books; the discontinuance of the writing, copying, signing and transmitting of many thousand letters which were merely formal in their nature; and many other changes of matters of detail.

The Treasury Commission recommended among other things: A system of accounts with officers of United States courts; a discontinuance of hand copying into record books of letters written and the substitution therefor of press copies or carbon duplicates; the destruction of useless files matter; supervision of the Lighthouse Service and accounts by special agents; the settlement of all the accounts of aided railroad companies by one auditor and comptroller; the extension into every branch of the public service of payments by disbursing clerks instead of by settlement on separate accounts; and the prohibition of clerical work by proxy. 
The report of the Treasury Commission was made to the Secretary of the Treasury on January 4, I889, and transmitted by the latter to the chairman of the Senate Select Committee on January i 8, i 889 .

The board appointed by the Secretary of War considered and reported upon the following topics: Requests for requisitions upon Treasury settlement certificates; rules and regulations for the War Department; certificates of deposit; army paymasters' collections; card-index records of rolls of volunteer army; credit requisitions for repayment of money into the Treasury; requisitions on the Public Printer; administration ; messenger service; supply division; daily report of work done; and correspondence.

In each case recommendations for changes and improvements were made by the board; which in nearly all cases were followed by orders of the Secretary of War directing the carrying into effect of those recommendations.

The War Department Board made its report to the Secretary of War on January 2I, I889, and the latter transmitted it to the chairman of the Select Committee of the Senate on January 23,1889 .

The results of these investigations of the Treasury and War Department commissions were embodied in a second report of the committee which was presented to the Senate by Mr. Cockrell, on March 27, I889, and ordered printed the following day.

\section{PUBLICATIONS}

Report [of] the Select committee of the United States Senate, appointed under Senate resolution of March 3, 1887, to inquire into and examine the methods of business and work of the executive departments, etc., and the causes of delays in transacting the public business, etc. March 8, I888. 3 v. in 2. (50th Cong., Ist sess. Senate. Report 507. Serial No. 2521-22.)

Contents.

Report (272 p.).

Detailed statement of methods of transacting of sundry items of public business, p. 4-I02.

Copying letter-press copies into records, p. I06-II2.

Public and rented buildings, insufficiency of room, and delay of business, p. I17-121.

Condition and arrears of business and efforts to remedy same, p. I2I-234.

Incumbrance and proper disposition of useless files of papers, existing laws, and reports from War Department, p. 240-253. 


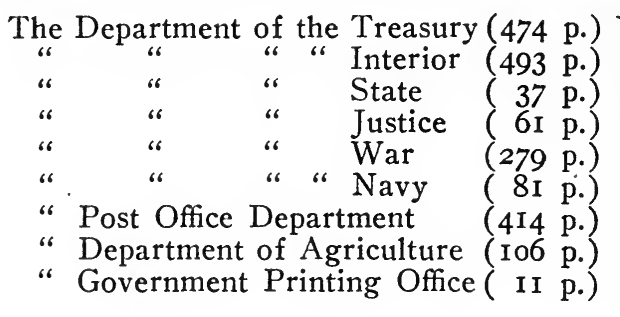

These pages give the replies made by the several bureau and division heads, in each of the departments, to the inquiries of the committee reg a $\mathrm{rding}$ condition of work, organization, a nd business methods.

Additional report of the Select committee of the United States Senate, . . etc. March 28, I889. 78 p., III, 3-220 p. (5Ist Cong., special sess., I889. Senate. Report 3. Serial No. 26I9.)

On verso of t.p.: Treasury document No. 1218. Secretary.

Contents.

Report, p. I-45.

Business methods of the Treasury department. Report of the Commission appointed in compliance with the request of the Senate Select committee, etc., p. 47-78.

The warrant system.

Report on the offices of the First Auditor, First Comptroller, and Commissioner of customs.

Report on the offices of the Second, Third and Fourth Auditors and Second Comptroller.

Report on letter files.

Report on bond issues.

Report on the office of the Register of the Treasury.

Fines, penalties, etc., placed in suit by collectors of customs.

Accounts of the Lighthouse board.

Moneys appropriated for public buildings.

Sales of revenue-cutters and marine hospitals.

Settlement of the accounts of the Pacific railroads.

Accounts current of aided railway companies.

Overdue liabilities of quartermasters and paymasters.

Indian claims.

Payment to employees in public buildings.

Presentation of duplicate vouchers.

Change of the quarters of the year.

Destruction of Treasury notes, etc.

Last sickness and burial claims.

The miscellaneous division of the Secretary's office.

Proxies.

A permanent commission recommended.

Business methods in the War department. Report of the Board appointed in compliance with the request of the Senate Select committee, etc. (220 p.)

Report of the Board, p. 9-12.

Appendixes, p. I3-I2I.

Request for requisitions on settlement certificates.

Rules and regulations of War department, June 4, I888.

Certificates of deposit. 


\section{AGENCIES FOR NATIONAL ADMINISTRATION}

Army paymaster's collections.

Card index record of rolls of Volunteer army. Credit requisitions.

Requisitions on Public printing.

Administration.

Messenger service.

Supply division.

Daily reports of work.

Correspondence. 
Joint Commission on Executive Departments, Organization, etc. (Dockery-Cockrell Commission) I893-1895. Though much good was accomplished by the Cockrell Committee, it was recognized that hardly a beginning had been made by it towards putting the business methods of the departments upon an efficient basis. The work of that committee demonstrated that if the best results were to be secured provision must be made for a more comprehensive investigation and that means must be provided for the employment of experts to make the detailed inquiries. Congress accordingly inserted in the legislative, executive and judicial appropriation bill for I894, approved March 3, I893, a clause providing for the creation of a special joint commission of the two houses to undertake such a work. This clause read:

That a joint commission, consisting of three Senators, members of the Fifty-third Congress, to be appointed by the present President of the Senate, and three members-elect to the House of Representatives of the Fifty-third Congress, to be appointed by the Speaker of the House of Representatives of the Fifty-second Congress, shall, during the Fifty-third Congress, inquire into and examine the status of the laws organizing the Executive Departments, bureaus, divisions, and other Government establishments at the National Capital; the rules, regulations, and methods for the conduct of the same; the time and attention devoted to the operations thereof by the persons employed therein, and the degree of efficiency of all such employees; whether any modification of these laws can be made to secure greater efficiency and economy, and whether a reduction in the number or compensation of the persons authorized to be employed in said Executive Departments or bureaus can be made without injury to the public service: Provided, That the commission herein authorized shall have no jurisdiction to inquire into and report on pension legislation. Said commission is authorized to employ not exceeding three experts, who shall render such assistance as the commission may require in the prosecution of the investigation herein required, and shall receive such compensation as the 


\section{AGENCIES FOR NATIONAL ADMINISTRATION}

commission shall determine to be just and reasonable. The heads of the respective Executive Departments shall detail from time to time such officers and employees as may be requested by said commission in their investigations. Said commission or any subcommittee thereof shall have power to send for persons and papers, and to administer oaths, and such process shall be issued and such oaths administered by the chairman of the commission or subcommittee, and the commission may report, by bill or otherwise, to their respective Houses of the Fifty-third Congress. All necessary expenses of said commission shall be paid out of any money in the Treasury not otherwise appropriated upon vouchers approved jointly by the chairman of said commission.

The powers and duties thus conferred were subsequently broadened and made more specific by the reference to the commission of certain bills and the passage of resolutions calling upon the commission to make other inquiries and reports.

The commission was constituted on the day the act became law through the appointment of the following as its members: House representatives, Alexander M. Dockery, chairman; James D. Richardson and Nelson Dingley. Senate representatives, Francis M. Cockrell, chairman; James K. Jones and Shelby M. Cullom. Mr. Dockery was made chairman of the joint committee. The clerks of the House and Senate Committees on Appropriations were appointed clerks of the commission. On May 24, I893, the commission appointed Messrs. J. W. Reinhart, C. W. Haskins, and E. W. Sells, experts, to assist in the commission's work.

On June 6, 1893, the active work of the experts began with an investigation of the accounting methods in the Treasury Department, and continued until the close of the $53 \mathrm{~d}$ Congress, on March 4, 1895, when the commission terminated.

The first work of the commission which obtained publicity was a compilation entitled: "References to laws organizing executive departments and other government establishments at the National Capital." This was presented on September 30, I893, and published as House Report No. 49 and Senate Report No. 4I, 53d Congress, Ist session. It was the first work of its character since the organization of the govern- 
ment and was prepared primarily for the use and information of Congress. This report presented the references to statutes in tabular form, showing for each governmental unit the title of the statute, its date, and the volume, page and section of the statute books.

The next report published was entitled: "Organization of the executive departments and other government establishments at the National Capital, and information concerning the persons employed therein," and was presented to both houses of Congress on October 9, I893, and printed as House Report No. 88 and Senate Report No. 47, 53d Congress, Ist Session. It shows in tabular form the number and title of each of the eight executive departments and the twelve other government establishments at the National Capital; the offices, bureaus and divisions of each; the number of persons authorized to be employed therein; their sex, age, and number of years employed, and other information concerning them.

The commission also made an inquiry into the condition of business in the several departments of the government at Washington, which inquiry disclosed that in but a small proportion of divisions was public business in arrears.

The commission's work, however, consisted mainly in studying the systems of administration, and recommending changes in the law for the improvement of existing methods and the abolition of useless work. A large number of important bills were reported by the commission, many of which were enacted into law.

The following laws were enacted as a direct result of the commission's work:

Enrollment of bills. A concurrent resolution providing for dispensing with the existing form of engrossing and enrolling bills and joint resolutions, and directing the use of printed copies of the same, agreed to in the House, October 26, and concurred in by the Senate, March I, I893.

Purchase of supplies. Amendment of Section 3709 of the Revised Statutes concerning contracts for fuel, ice, stationery and other miscellaneous supplies for the executive departments and other government establishments in Washington, approved January 27, I894.

Accounts of the. Treasurer. Repeal of Section 3I I of the 68 


\section{AGENCIES FOR NATIONAL ADMINISTRATION}

Revised Statutes thereby abolishing a useless voluminous report, approved March 19, I894.

Deposits of Postmasters. Amendment of Section 407 of the Revised Statutes so as to require original receipts for deposits of postmasters to be sent to the Auditor of the Treasury for the Post Office Department, approved January 22, I894.

Methods of Accounting in the Post Office Department, etc. An act to improve the methods of accounting in the Post Office Department and substituting the money-order system for the postal note, approved January 27, I894.

Property Returns. An act to regulate the making of property returns by officers of the government, approved March I9, I894.

Destruction of Old Money. Orders. An act authorizing the Secretary of the Treasury and the Postmaster General to destroy all money orders and postal notes more than ten years old and papers relating thereto, approved July I6, I894.

Methods of Accounting in the Treasury. An act to improve the methods of accounting in the Treasury Department, introducing a more efficient system of accounting, and abolishing the offices of Commissioner of Customs and Second Comptroller. One provision of this act resulted in the consolidating of the draft and the warrant into one piece of paper in the office of the Secretary of the Treasury. Approved July 3I, I894.

Reports of Purchases of Military Supplies. Repeal of Section 229 of the Revised Statutes thereby dispensing with unnecessary reports, approved March 2, I895.

Bonds of Govermment Officials. An act requiring that all bonds of certain government officials shall be transmitted to the Secretary of the Treasury and filed as he may direct, etc., approved March 2, I895.

Names of Employees in Departments. Repeal of Section I94 of the Revised Statutes requiring the head of each department to make an annual report to Congress of the names of the clerks and other persons employed in each department, the offices thereof, etc., approved, March 2, I895.

Purchase of Coal and Wood. Amendment of Section 37 I of the Revised Statutes so as to prohibit payment of fees for 
inspecting coal and wood purchased for the use of the government, approved March 2, 1895.

In addition to the above changes in the law, the following improvements were made, through the work of the joint commission, without legislation:

Statistics of International Money Orders. Dispensing with a considerable amount of valueless statistics formerly prepared by the Auditor for the Post Office.

General Land Office. Consolidation of certain divisions of the General Land Office and the preparation of patents in the Office of the Recorder.

Customs Service. A change in the method of collecting the customs and rendering accounts of the same to the Auditor for the Treasury.

Books, Stationery, Rent, etc. Economies effected in books, stationery, furniture, printing and room rent in government offices on account of changes, consolidations and improvement in methods.

A considerable number of recommendations were made and much information was furnished by the joint commission to Congress concerning matters which, at its termination, had not resulted in the enactment of laws or had not been put into effect by departmental regulation. These recommendations related to: A reorganization of the Office of Supervising Architect of the Treasury Department; methods of hearing contested land cases; repeal of the "Contest" Act of I880; receivers of local land offices; public surveys; abolition of the Office of Solicitor of Internal Revenue; further recommendations concerning bonds of government officials; checking of money orders; abolition of the Office of Naval Officer in the Customs Service, and system of writing and recording letters sent.

The commission estimated that the adoption of its recommendations above outlined effected a reduction in personnel of $25 \mathrm{I}$ clerks earning salaries aggregating \$360,6 Io per annum, and an annual saving of $\$ 246,98 \mathrm{I}$ in miscellaneous expenses, or a total saving of $\$ 607,59 \mathrm{i}$.

The other recommendations which had failed of adoption at the termination of the commission, would, it was claimed, have effected a total additional saving of $\$ 449,928$, of which 
$\$ 33^{6,928}$ represented the aggregate salaries of 252 clerks and \$I 3,000 miscellaneous expenditures which could have been dispensed with.

The total expense of the commission amounted to $\$ 4 \mathrm{r}, 264$, of which $\$ 35,614$ was paid to the experts; the balance was expended for clerical service, room rent, supplies, etc.

\section{PUBLICATIONS}

References to laws organizing cxecutive departments and other government establishments at the national capital. Sept. 30, I893. II, I75 p. (53d Cong., Ist sess. House. Rept. No. 49.)

Issued also as Senate Rept. No. 4I, 53d Cong., Ist sess.

Contains in addition to references to and extracts from all the laws organizing executive departments and other establishments, references to laws regulating compensation and employment of clerks, copyists, messengers, watchmen, and laborers; leaves of absence; and hours of service in the executive departments, p. I62-I65.

Organization of the executive departments and other government establishments at the national capital, and information concerning the persons employed therein. October 9, 1893. 207 p. I fold. tab. (53d Cong., Ist sess. House. Rept. No. 88.)

Issued also as Senate Rept. No. 47, 53d Cong., Ist sess.

Dispensing with the present form of engrossing and enrolling bills and joint resolutions and dirccting the use of printed copies of the same. October 26, IS93. 2 p. (53d Cong., Ist sess. House. Rept. No. 145.)

Issued also as Senate Rept. No. 58, 53d Cong., Ist sess.

Contracts for fuel and other supplies for the departments. October 30, I893. Report [to accompany H. R. 4292] 2 p. (53d Cong., Ist sess. House. Rept. No. I52.)

Issued also as Senate Rept. No. 6r, 53d Cong., Ist sess.

Deposits of postmasters. December 12, I893. Report [to accompany H. R. 4340] i p. (53d Cong., 2d sess. House. Rept. No. 208.)

Issued also as Senate Rept. No. II6, 53d Cong., 2 d sess.

Methods of accounting in the Post Office department, etc. December I3, I893. Report [to accompany H. R. 46Io]. I8 p. 2 forms. (53d Cong., $2 \mathrm{~d}$ sess. House. Rept. No. 210.)

Issued also as Senate Rept. No. 93, 53d Cong., 2 d sess.

Accounts of the Treasurer. February 3, I894. Report [to accompany H. R. 5529]. 2 p. (53d Cong., $2 \mathrm{~d}$ sess. House. Rept. No. 349.)

Issued also as Senate Rept. No. 200, 53d Cong., 2d sess.

Making of property returns by officers of the government. February 4, I894. Report [to accompany H. R. 5530]. 6 p. (53d Cong., 2 d sess. House. Rept. No. 392.)

Issued also as Senate Rept. No. 201, .53d Cong., 2d sess.

Methods of accounting in the Treasury. March 6, I894. Report [to accompany H. R. 5750]. 6 p. (53d Cong., $2 \mathrm{~d}$ sess. House. Rept. No. 409.)

Issued also as Senate Rept. No. 240, 53d Cong., 2d sess. 


\section{EFFORTS FOR ADMINISTRATIVE REFORM}

Methods of accounting in the Treasury. March 29, I894. Report [to accompany H. R. 6478]. 35 p. (53d Cong., 2d sess. House. Rept. No. 637.)

Issued also as Senate Rept. No. 293, 53d Cong., 2d sess.

Methods of accounting in the Treasury. May I, I894. Report [to accompany H. R. 6948]. I p. (53d Cong., 2d sess. House. Rept. No. 822.)

This was not issued as a Senate report.

Proposed change in form of Treasury warrants. May 26, 1894. Report. 3 p. (53d Cong., 2d sess. House. Rept. No. 970.)

Issued also as Senate Rept. No. 447, 53d Cong., 2d sess.

Disposition of old money orders. May 26, I894. Report. 2 p. (53d Cong., 2d sess. House. Rept. No. 97I.)

Issued also as Senate Rept. No. 448, 53d Cong., $2 \mathrm{~d}$ sess.

International money order statistics. May 26, I894. Report. 3 p. (53d Cong., 2d sess. House. Rept. No. 972.)

Issued also as Senate Rept. No. 449, 53 d Cong., $2 \mathrm{~d}$ sess.

Contested land cases. January 15,1895 . Report [to accompany H. R. 849I]. 7 p. (53d Cong., 3d sess. House. Rept. No. I584.)

Issued also as Senate Rept. No. 769, 53d Cong., 3d sess.

Engrossing and recording of land patents. January 23 , 1895 . Report [to accompany H. R. 8490]. I2 p. (53d Cong., 3d sess. House. Rept. No. 1652.)

Issued also as Senate Rept. No. 808, 53d Cong., 3d sess.

Purchases of coal and wood. January 3I, I895. Report [to accompany H. R. 8716]. 6 p. (53d Cong., 3d sess. House. Rept. No. I736.)

Issued also as Senate Rept. No. 865, 53d Cong., 3d sess.

Repeal of section 194. Revised statutes of the United States. [Annual reports of government employees.] February 4, I895. Report [to accompany H. R. 8754]. 2 p. 53d Cong., 3d sess. House. Rept. No. 1759.)

Issued also as Senate Rept. No. 875, 53d Cong., 3d sess.

Section 229 of the Revised statutes of the United States. Reports of purchases of military supplies. February 15, 1895. Report [to accompany H. R. 8879]. 5 p. (53d Cong., 3d sess. House. Rept. No. 1839.)

Issued also as Senate Rept. No. 932, 53d Cong., 3d sess.

Condition of business in the departments of the government at Washington. February 18, I895. Report. 4I p. (53d Cong., 3d sess. House. Rept. No. I851.)

Issued also as Senate Rept. No. 952, 53d Cong., 3d sess.

Registers and receivers of land offices. February 22, 1895. Report. 6 p. (53d Cong., 3d sess. House. Rept. No. 1908.)

Issued also as Senate Rept. No. 1023, 53d Cong., 3d sess.

To abolish office of Solicitor of internal revenue. February 22, 1895. Report [to accompany H. R. 8939]. 3 p. (53d Cong., 3d sess. House. Rept. No. 1909.)

Issued also as Senate Rept. No. 1024, 53d Cong., 3d sess.

Bonds of officers of the United States. February 22, I895. Report [to accompany H. R. 8704]. I2 p. (53d Cong., 3 d sess. House. Rept. No. 1910.)

Issued also as Senate Rept. No. 1022, 53d Cong., 3d sess. 


\section{AGENCIES FOR NATIONAL ADMINISTRATION}

To improve the public surveys. February 28, 1895. Report [to accompany H. R. 8504]. 29 p. (53d Cong., 3d sess. House. Rept. No. 1954.)

Issued also as Senate Rept. No. 102I, 53d Cong., $3 \mathrm{~d}$ sess.

Checking money orders. March 2, I895. Report. 4 p. (53d Cong., 3 d sess. House. Rept. No. 1973.)

Issued also as Senate Rept., No. 1035, 53d Cong., 3d sess.

Reorganization of Supervising architect's office. March 2, 1895 . Report. Io p. (53d Cong., 3d sess. House. Rept. No. 1974.)

This was not issued as a Senate report.

Collecting customs and rendering accounts therefor. March 2, I895. Report. 37 p. (53d Cong., 3d sess. House. Rept. No. 1975.) Issued also as Senate Rept. No. I033, 53d Cong., 3d sess.

Preserving copies of letters written in the departments. March 2, I895. Report. 3 p. (53d Cong., 3d sess. House. Rept. No. 1976.)

Issued also as Senate Rept. No. 1034, 53d Cong., 3d sess.

A review of the work done by the Joint commission-reorganization of the accounting system and business methods in the executive departments. March 2, I895. Report. 30 p. (53d Cong., 3d sess. House. Rept. No. 2000.)

This was not issued as a Senate Report.

The above House Reports are bound together in "The Reports of Committees of the House of Representatives for the First Session of the Fifty-third Congress, I893," volume 2, I895. Serial No. 3158. The above Senate Reports are bound together in "The Reports of Committees of the Senate of the United States for the First Session of the Fifty-third Congress, I893," volume 2, I895. Serial No. 3148. 


\section{Committee on Department Methods (Keep Committee)} 1905-1909. On June 2, 1905, President Roosevelt, upon his own initiative and without congressional direction, appointed the following committee "to investigate the business methods and practice of the Executive Departments and to report plans for their improvement:" C. H. Keep, Assistant Secretary of the Treasury; Lawrence O. Murray, Assistant Secretary of Commerce and Labor; James Rudolph Garfield, Commissioner of Corporations, Department of Commerce and Labor, and Gifford Pinchot, Chief of the Forest Service, Department of Agriculture. Frank H. Hitchcock, First Assistant Postmaster General, was originally appointed but his name appears only on the first two reports.

Soon after its appointment the committee brought about the organization of assistant committees to take up certain lines of its work for special detail investigation. Through the activities of these various assistant committees and the coöperation of the department, bureau and division chiefs in the government service, much valuable information was gathered, and some important recommendations were made. There being no funds available for the employment of experts or for other services, the work of the committee was done almost entirely by employees of the government service. On June 30, 1906 (34 Stat., 635), a small appropriation of $\$ 5,000$ was made, instead of $\$ 25,000$ as requested by the President, "for salaries or compensation of persons not otherwise employed by the United States, and needed in the service of the Committee on Department Methods."

The investigations of the committee covered a large variety of subjects, and while eighteen reports on as many different topics were made to the President a very considerable part of the committee's work never reached publicity. Brief accounts of the published reports follow in chronological order.

Purchase of Typesetting Machines. The first report of 
the committee, made on August 4, 1905, was the result of an investigation of certain charges made against the Public Printer by one manufacturer on account of a contract made with a rival concern. The report was based upon evidence presented at hearings and personal investigations made by the committee.

Public Printing. On September 30, 1905, a statement on the cost of public printing and binding was made to the President by the Acting Public Printer, which statement was referred to the committee with the query, "How much too much is printed?" The committee in its report made on January 2, I906, found upon investigation that there was (I) excessive cost in executing work at the Govermment Printing Office; (2) unnecessary size and variety of documents originating in the departments and the printing of unimportant departmental documents; (3) excessive editions of documents originating in the departments, and waste by duplicate distribution; (4) unnecessary printing originating in and done for Congress.

Government Crop Reports. This report issued January 30, 1906, was the result of a resolution of the New England Cotton Manufacturers' Association requesting the President to appoint a commission to investigate the best methods of issuing government crop reports. In this report the committee recommended changes in the methods of making estimates, avoidance of duplicate estimates of crop acreage and yield by the Census Bureau and the Bureau of Statistics, greater cooperation with the Weather Bureau and a change in the title of the Burean of Statistics. This report was also published as Senate Document No. 464, 59th Congress, Ist Session.

Interdepartmental Telephone Service. The committee, through a subcommittee, made a study of the telephone service, and as a result obtained an agreement whereby a saving of $\$ 1,500$ a year on the cost of rented wires in the District of Columbia was effected. In its report of March 19, 1906, it also recommended that most of the private branch exchanges be mutually connected by a system of tie lines consisting of wires rented from the telephone company. By this means the committee expected that a considerable saving could be effected and much better service obtained. An estimate of an appropriation for an improved telephone service between executive 
departments appears in H. R. Document No. 390, 59th Congress, $2 \mathrm{~d}$ Session.

Investigation of the Twelfth Census Report on Agriculture. As a result of the difference in estimates of the Bureau of Statistics and the Census Bureau for the year I899, disclosed in the committee's report of January 6, I906, the committee was instructed by the President to investigate the accuracy of the census statistics of agriculture. In its report of May I, I906, the committee stated that in its opinion "the agricultural returns of the Twelfth Census are substantially accurate, that they are more accurate than the agricultural returns of any previous Census, and that they did at the time they were published furnish an accurate basis upon which the estimates of the Division of Statistics could be based and could be judged." This report was also published as a part of Senate Document No. 464, mentioned above.

Methods of Rendering and Stating Accounts. A subcommittee of the Committee on Department Methods, selected to consider questions of bookkeeping and accounting, undertook an investigation of the methods followed by disbursing and collecting officers of the United States in rendering and stating for the various auditors their accounts current with the government. There was want of uniformity in the practice of disbursing officers, two systems-the "Separate" and the "Consolidated" being in use, and the effort of the subcommittee was to determine which was the better of the two methods in use and to bring about the uniform use of the superior system. After investigation, including hearings, the subcommittee recommended that "all accounts of disbursing and collecting agents of the government be stated in consolidated form, to be prescribed by the Comptroller under the direction of the Secretary of the Treasury, except such accounts as may be shown to the satisfaction of such officers to be impracticable of consolidation." This recommendation met with the approval of the committee and the officers concerned, and on May 24, 1906, the Comptroller issued a circular putting it into effect. The committee's report of June 8, 1906, on this subject is a detailed statement of the above facts.

Purchase of Department Supplies. This subject was studied by a subcommittee, at the head of which was the Direc- 
tor of the Bureau of Standards. It had already received much attention from the Dockery Commission in 1893, resulting at that time in an amendment to Section 3709, Revised Statutes, providing that contracts for purchase of department supplies should go before a Board of Award composed of Assistant Secretaries of the Treasury and Interior Departments and an Assistant Postmaster General. While that amendment accomplished something in securing uniformity of price since 1893 , it did not accomplish the purpose intended by the Dockery Commission. The plan suggested by the subcommittee proposed that: "Provision be made by which the preparation of schedules, advertising for proposals, and making of contracts for the purchase of Department supplies, are placed in the hands of a board to be known as the General Supply Committee." This committee, which was to replace the existing Board of Award, was to be composed of one expert employee from each department to be designated by the head thereof. This committee was to prepare annually a schedule of miscellaneous supplies in use in the government service, prepare the necessary advertisements, open all bids submitted pursuant to such advertisement, and recommend awards to the secretary authorized to make the contracts. The Committee on Department Methods in its report of December 6, I906, and the President in a subsequent message to Congress, recommended the amendment of Section 3709 in accordance with this suggestion. No action was then taken by Congress, but on June I7, I9I0, an act was approved creating a General Supply Committee in the Treasury Department which has probably accomplished the same object. This report was also published as Senate Document No. 106, 59th Congress, 2d .Session.

The Use of Committees in Department Work. A report, dated December 6, I906, recommends the establishment of department committees, points out their value to heads of departments and bureaus and to subordinates, how and for what purposes they should be created, and some of the dangers to be avoided in their creation.

Transportation of Government Employees and Property. A comprehensive report was made by the assistant committees on accounting and supplies through a special joint committee, which the Committee on Department Methods presented with 
its recommendations in its report to the President dated December 6, I906. This report deals with the "failure to follow the best usages" and the "lack of uniformity in handling shipments and settling transportation accounts" in the government service. Among the recommendations made by the committee are: (I) That "all single shipments of freight and continuous journeys of Government employees be made on through bills of lading or transportation requests; (2) that standard forms of bills of lading (following commercial practices) and transportation vouchers be prepared and prescribed; (3) that a manual of instructions for Government transportation be compiled by a special committee, and that after approval by the President it be followed by all Departments and services; (4) that clerks in the offices of the various auditors now engaged in the examination of transportation accounts be assembled in one place and that they be there provided with, for their use, a complete common file of tariffs, schedules and division sheets; (5) that the officers of the Quartermaster's Department be instructed, when requested, to advise disbursing officers and other officers of the government, to the extent of their facilities, upon questions of classification, rates and division of rates."

Annual Leave, Sick Leave and Hours of Labor. A report submitted December 24, I906, gives a history of the law and practice of the government departments with regard to leaves of absence and hours of labor, calls attention to lack of uniformity in the methods of carrying out the provisions of law concerning leaves of absence, and presents a set of proposed regulations to govern all departments and independent bureaus and offices in the District of Columbia.

Costkeeping in the Government Service. A study was made of costkeeping in the government service by a subcommittee, and its findings were embodied in a report dealing with the theory of costkeeping, in the form of a "Primer on Costkeeping in Government Work," and with conditions in certain important branches of the service.

Classification of Positions and Gradation of Salaries. The committee with the assistance of a subcommittee worked out an elaborate schedule of classification of positions and gradation of salaries for employees of the government in 


\section{ACIENCIES FOR NATIONAL ADMINISTRATION}

Was hington with recommendations for its adoption. The main features of this schedule are (I) to fix the lower salaries suffir -iently high to attract competent persons to the service, and the higher salaries sufficiently high to retain the best expe $\mathrm{rt}$ service; (2) to grade salaries sufficiently to assure freques at promotion as a stimulus to the best efforts; (3) to grade and equalize salaries according to the character and the respo nsibility of the work performed. The President sent two me. ssages to Congress giving estimates for salaries in accordarice with this schedule, prepared by a special committee $(H$. R. Doc. No. 648, 6oth Cong., Ist Sess., and S. Doc. No. 638, 60 th Cong., 2 d Sess.), and a bill was introduced providing for its adoption, but no legislation resulted.

Official Bonds. An investigation made by an assistant committee on accounting, the results of which were submitted in a report of the committee dated January 7, 1907, disclosed a ereat variety in the form of official bonds, that is, a diversity ". $p$ t the statement of conditions, in the order in which the several parts of the bond are printed, in the substance, character and relation of the instructions for execution to other parts of the bond, and in the fact that in some bonds the laws under which they are executed are set out, while in others no such information is given." The committee recommended that the various kinds of official bonds be classified and a standard form adopted for each class, these standard forms to be prepared in the office of the Comptroller of the Treas. ury after consultation with the solicitors of the various executive departments and the disbursing and collecting officers affected. Recommendations are also made concerning cumulative bonds and the custody of bonds.

Assembling of Disbursing Officers' Checks and Vouchers, etc. Another report of the accounting committee transmitted by the Committee on Department Methods, January 9, 1907, makes recommendations intended to remedy several of the more serious defects in the existing system of accounting. The assistant committee took up three subjects relating to accounts of disbursing officers for consideration, namely: (r) the assembling of disbursing officers' paid checks with their vouchers in the auditors' offices; (2) the "draft voucher" or "check Voucher"; (3) the taking of vouchers in duplicate by disburs- 


\section{EFFORTS FOR ADMINISTRATIVE REFORM}

ing officers. After pointing out the defects in the present system, the assistant committee suggests a plan which it considers suited to government needs.

Treasury Bookkeeping. A special committee of the as sistant committee on accounting made a study of the exis ing system of Treasury bookkeeping. In a report embodying its conclusions, dated January I9, 1907, the Committee on : Department Methods points out the incompleteness of the ex isting system which is a consolidation of a number of syste ms assembled upon the passage of the Dockery Act (28 Statt, 205), and suggests in lieu thereof a comprehensive systiem of double-entry bookkeeping which is outlined. This proposed system was submitted to and approved by a committee of cerrtified accountants appointed by the American Association of Public Accountants. The adoption of the proposed system required no new legislation.

Government Contracts. The committee in a report, dated April 30, 1907, calls attention to the defects in the forms it many government contracts, the onerous and unreasonabe conditions sometimes unnecessarily imposed upon contractors, the waste involved in preparing too many copies, and the diversity of practice in the examination bonds and in the requirement of bonds from contractors. The committee recommended the appointment of a special committee by the President to study the subject of government contracts and "to prepare and prescribe, subject to the approval of the legal officer of each Department, such forms for contracts as may be deemed necessary for such Department, bureau, or office."

Superannuation of Civil Service Employees. In a report dated February 18, 1908, the committee presented a bill for the retirement of employees in the classified service of the government. This proposed plan, the central idea of which originated with Herbert D. Brown, provided for an annuity (or an equivalent cash sum) to be paid each employee upon his reaching the age of 70 years, equal to 1.5 per cent of his pay for every year of service. The funds necessary for the payment of the annuity, according to this plan, were to be furnished by the employees without expense to the governmen"s other than the payment of allowances to those employees now in the service whose contributions would not be sufficient to 
provide for their own retirement, each employee to contribute the amount necessary to create his own annuity without regard to payments of others. Statistics are given in the report illustrating the working of the proposed plan and indicating the probable expense to the government on account of those already in the service. This report was also published as Senate Document No. 308, 6oth Congress, ist Session.

Documentary Historical Publications of the United States Government. On January II, I909, the Committee on Department Methods presented the results of an inquiry made by an assistant committee of experts, selected mostly from the faculties of leading universities, to study the method of dealing with the problem of documentary historical publications of the United States government. The report of this assistant committee reviews the course hitherto pursued by the government in the matter of historical publications, indicating the cost and criticising the want of method; gives a general survey of the field of United States history, showing what has been done to cover it by government documentary publications, what gaps exist in the record needed to be filled in by government action, and general considerations as to the proper policy to be pursued by the government with respect to historical publications; reviews the systems pursued by other governments; and makes suggestions and presents a draft of a bill for a permanent commission on national historical publications. This report was also published as Senate Document 7I4, 6oth Congress, 2d Session, dated February I I, I909.

It is much to be regretted that, with the exceptions named, these reports of the Keep Commission were never published as public documents. The result is that they are exceedingly difficult to obtain. The set possessed by the Institute for Government Research is, in fact, the only complete set of which the author of the present volume has knowledge.

\section{PURLICATIONS}

Purchase of typesetting machines for the government printing office. August 4, 1905. $26 \mathrm{p}$.

Public printing. January 2, I906. I2 p.

Government crop reports. [Report on the work of the Bureau of statistics of the Department of agriculture.] January 6, Igo6. 63 p.

Issued also in Senate Doc. 464, 59th Cong., Ist sess. 


\section{EFFORTS FOR ADMINISTRATIVE REFORM}

Interdepartmental telephone service. March I9, rgo6. 6 p.

Investigation of the Twelfth census report on agriculture. May I, I906. $8 \mathrm{p}$.

Issued also in Senate Doc. 464, 59th Cong., Ist sess.

Method of rendering and stating accounts. [Methods followed by disbursing and collecting officers of the United States in rendering and stating for the various auditors their accounts current with the government.] June 8, Igo6. 3 p.

"Method of rendering and stating accounts. Treasury department. Circular No. 46," p. 7-9.

Purchase of department supplies. December 6, rgo6. I7 p.

Issued also as Senate Doc. I06, 59th Cong., 2d sess. Serial No. 5070.

Contents Report on the standardization and method of purchase of department supplies.

Proposed amendment to section 3709, Revised Statutes.

Report of subcommittee.

Contracts for fuel and other supplies for the Departments. [Report of the Dockery commission, Oct. 30, 1893.]

Opinion of the Attorney-General.

The use of Committees in department work. December 6, rgo6. 7 p. Transportation of government employees and property. December 6, 1906. I2 p.

Annual leave, sick leave, and hours of labor. December 24, I906. Io $\mathrm{p}$.

Costkeeping in the government service. December 29, I906. 22 p. "Primer on costkeeping in government work," prepared by Norman E. Webster, Jr. [and others], p. 9-22.

Classification of positions and gradation of salaries for employees of the Executive departments and independent establishments in Washington. January 4, I907. I6 p.

Official boncis. January 7 , 1907. II $\mathrm{p}$.

"Appendix" [containing a copy of the proposed amendment to the law and the Attorney-General's opinion on the same], p. 8-I I. Assembling disbursing officers' checks and vouchers and verification of disbursing officers' balances. January 9, I907. I6 p.

Treasury bookkeeping. January I9, 1907. Io p.

"Report of the Committee of the American association of public accountants on Treasury bookkeeping," p. ro.

Government contracts. April 30, 1907. 7 p.

Superannuation of civil-service employees of the government [together with draft of a proposed bill providing for the payment of annuities to employees upon retirement]. February I8, I908.

Issued also as Senate Doc. No. 308, 6oth Cong., Ist sess. Serial No. 5265 .

Documentary historical publications of the United States government. January II, I909. 4I p.

Contents.

Review of the course hitherto pursued by the government in the matter of historical publications.

General survey of the field of United States history showing what has been done to cover it by government documentary publications. 


\section{AGENCIES FOR NATIONAL ADMINISTRATION}

Recapitulation of the recommendations made in the course of this survey.

General considerations as to the proper policy to be pursued by the government in respect to historical publications.

Statement of the system pursued by other governments.

Suggestions for a permanent commission on national historical publications.

Draft of a bill to create a permanent commission on national historical publications.

Same, with title: Report on documentary historical publications of United States government, with draft of bill providing for creation of permanent commission on national historical publications. February I I, I909. 45 p. (6oth Cong., 2 d sess. Senate Doc. 7I4. Serial No. 5408.)

\section{PUBLICATIONS OF THE GRADES AND SALARIES COMMITTEE OF THE COMMITTEE ON DEPARTMENT METHODS}

Executive order (authorizing formation of Grades and salaries committee, personnel of same, with extracts from report of Department methods committee on classification of positions and gradation of salaries for employees of executive departments and independent establishments in Washington.) I907. 4 p.

Estimates for salaries in executive departments and establishments. (I909, in conformity with schedules and recommendations of Committee on department methods of January 4, I907.) I908. I23 p.

Same [with estimates for salaries for arsenals and navyyards]. February I I, I908. I75 p. (6oth Cong., Ist sess. House Doc. 648. Serial No. 5370.)

Estimates for salaries in executive departments and [independent] establishments, 1910. January 6, 1909. I26 p. (6oth Cong., $2 \mathrm{~d}$ sess. Senate Doc. 638. Serial No. 5395.)

\section{HEARING BEFORE CONGRESSIONAL COMMITTEE}

Proposed reclassification of clerical force in the executive departments. Supplement to hearings before subcommittee of House Committee on appropriations in charge of deficiency appropriations for 1907 and prior years on General deficiency bill. Statement of Hon. Charles H. Keep, chairman of the Committee on department methods. January 15, 1907. 9 p. 
President's Commission on Economy and Efficiency, r9ror9r3. Much the most comprehensive and systematic investigation that has ever been made of the administrative branch of the national government, if not, indeed, of any government, was that made by a special commission known as the "President's Commission on Economy and Efficiency." Though the prosecution of this inquiry was authorized by Congress, such authorization was made at the direct request of President Taft. In response to his request, Congress inserted in the sundry civil appropriation act for I9I I, approved June 25, I9I0, the following clause:

To enable the President, by the employment of accountants and experts from official and private life, to more effectively inquire into the methods of transacting the public business of the government in the several executive departments and other government establishments, with the view of inaugurating new or changing old methods of transacting such public business so as to attain greater efficiency and economy therein, and to ascertain and recommend to Congress what changes in law may be necessary to carry into effect such results of his inquiry as cannot be carried into effect by executive action alone, and for each and every purpose necessary hereunder, including the employment of personal services at Washington, District of Columbia, or elsewhere, one hundred thousand dollars.

The appropriation of $\$ 100,000$ here made for the conduct of this inquiry was supplemented by one for $\$ 75,000$ contained in the sundry civil appropriation act for 1912, approved March 4, I9II, one for $\$$ IO,OOO to meet the expenses of a special investigation of the Patent Office which Congress, by joint resolution of August 2I, I9I2, directed the President to have made, and one for $\$ 75$, o0o contained in the sundry civil appropriation act for I9I3, approved August 24, I9I2. The total appropriation for defraying the expenses of the inquiry was thus $\$ 260,000$, and its life extended nver the three fiscal years, July I, I9Io, to June 30, I9I3. 
It will be noted that, though Congress authorized the investigation and appropriated money for its support, full discretion was left to the President to determine the character of organization that should be created for its prosecution and the methods that should be employed. As a first step the President placed his secretary, Mr. Charles D. Norton, in full charge of the work. The latter called upon Dr. F. A. Cleveland, then Director of the Bureau of Municipal Research of the City of New York, to assist him in the organization and conduct of the work. Active work began on September 27. 19I0, when Dr. Cleveland reported for duty.

The next step consisted in the President's requesting the head of each department and certain independent establishments to appoint from among the officers of his department or establishment a "committee on economy and efficiency," which should have as its duty the making of inquiries into the organization and methods of business of the department or establishment, and of formulating proposals looking to the improvement of existing conditions. Such committees were duly appointed and began work.

In the meantime steps were taken looking to the building up of a central organization to have general charge of the inquiry. This was done by the creation of what was known as "The President's Inquiry in re Economy and Efficiency," with Dr. Cleveland as its directing head. The latter, as a preliminary step, caused to be sent out, with the approval of Mr. Norton and the President, a circular letter addressed to the heads of all departments and establishments calling for detailed information regarding their organization, personnel, legal status and powers and many features of their administration. Numerous conferences were also held with the departmental committees on economy and efficiency.

It soon became evident, however, that if the work was to be efficiently prosecuted a more formal central organization had to be established. In compliance with the recommendation of Dr. Cleveland and Mr. Norton, the President, on March. 8. IOII, created a body to which he gave the name of "President's Commission on Economy and Efficiency," to have full charge af the inquiry. The commission was made to consist of the following five members: Dr. Frederick A. Cleveland, 


\section{EFFORTS FOR ADMINISTRATIVE REFORM}

chairman; Mr. William F. Willoughby, then Assistant Director of the Census; Judge Walter W. Warwick, Associate Justice of the Supreme Court of the Canal Zone, and formerly examiner of accounts of the Isthmian Canal Commission and auditor of the government of the Canal Zone; Mr. Frank J. Goodnow, Professor of Administrative Law, Columbia University, and $\mathrm{Mr}$. Harvey S. Chase, a certified public accountant of Boston, Mass. Mr. Merritt O. Chance, then Auditor for the Post Office Department, was made secretary and later a member of the commission.

Provision was also made for two other bodies to assist in the undertaking - a Board of Referees and a Board of Consulting Experts-both of which were created to act in an advisory capacity. The Board of Referees was composed of government officials selected by the President, who conferred upon it the function of considering such technical questions as interdepartmental disputes, conflicts of jurisdiction and the like which might be referred to it for special consideration and report.

The Board of Consulting Experts was composed of members of accounting firms which had been connected with previous inquiries into the affairs of the government. The duty imposed upon this board consisted of giving its opinion regarding technical questions of accounting and all business practices and procedure that were referred to it.

Due to unavoidable delay in all the members of the commission reporting for work, and in assembling an adequate technical and clerical staff, the commission as such did not begin active operations until about July, I9I I. It resulted, therefore, that the inquiry as a whole was made under two auspices and covered two periods, that of the "President's Inquiry in re Economy and Efficiency," under the "immediate direction of Dr. F. A. Cleveland during the first year, and that of the "President's Commission on Economy and Efficiency" during the last two years of the three-year period.

The work done during the first period necessarily consisted largely in assembling documents and data regarding the organization and operations of the government, though a distinct beginning was made in the prosecution of certain technical studies such as standardization of expenditure documents and 


\section{AGENCIES FOR NATIONAL ADMINISTRATION}

procedure, the classification of objects of expenditure, classification of estimates of appropriation, and regulations governing expenditures for travel.

Upon the organization of the commission a more formal work program was adopted. In general terms this program comprehended the prosecution of studies under the following five heads:

I. The problem of a national budget

2. Problems of organization

3. Problems of personnel

4. Problems of financial procedure

5. Problems of business practice and procedure

Though reference to the publications of the commission as given hereafter will indicate in terms of published products the work done in each of these fields, some description of the methods pursued and the objects sought will not be out of place.

The Problem of a National Budget. From the start of the inquiry, every effort was made to develop information showing the need for the adoption by the national government of a budget system and the steps that had to be taken in order to accomplish this reform. As has been pointed out, a study of the classification of estimates of appropriation had been begun by the President's Inquiry in re Economy and Efficiency. This work was continued by the commission, which, in conference with representatives of the departments, worked out a reclassification of expenditures, appropriations and estimates which would show these data in the form desired for budgetary purposes. This done, the departments and other services of the government were, in July, I9I I, requested to submit to the commission statements of their expenditures for I9II, appropriations for I9I2, and estimates for I9I 3 in accordance with such classification. This classification was devised with a view to making known expenditures, appropriations and estimates in terms of organization units, character, that is, capital outlay, fixed charges, current expenses, etc., functions, objects, that is, things purchased, personal services, supplies, etc., and appropriation bills.

On June 27, I9I2, the information thus secured, together with other data bearing upon the problem of a budget, was 
submitted to Congress in the form of a report entitled "The Need for a National Budget." This report, which covered 568 pages, consisted of three parts and appendices. In Part I was given the history and description of existing practices of the Executive and Congress in respect to the preparation of estimates and the enactment of appropriation bills; in Part II, a discussion of the constructive recommendations of the commission; and in Part III, a pro forma budget and supporting documents. The appendices gave a digest of existing laws governing estimates and appropriations, a bibliography of congressional inquiries into the conduct of the business of the executive departments, and a statement of budget methods and procedure in foreign countries. The report also included a letter of transmittal by the President in which the proposal that provision be made for the adoption of a budget system was strongly indorsed. In this letter the President called attention "to the fact that the Government is without an accurate statement of resources and liabilities; that it is being financed without a prospectus which shows expenditures in relation to revenues or the effect of past financial policy; that the reports of expenditures and the estimates required by law are unsystematic, lack uniformity of classification, and are incapable of being summarized in such a manner as to give to the Congress, to the President, or to the people a picture of what has been done or what is proposed."

These defects he pointed out could only be adequately met by the adoption of a scientifically worked out budget system.

This first report was intended merely as a means of raising the whole question of budgetary reform. To push the matter still further, it was decided to attempt to prepare an actual budget for the next fiscal year in conformity with the principles that had been developed by the commission. Such a budget of course would not take the place of the estimates which had to be submitted in compliance with legal requirements in their established forms, but would be an alternative or supplemental method of getting before Congress appropriation data.

On July IO, I9I2, the President accordingly addressed a letter to the heads of the executive departments and other government establishments informing them that it was his 


\section{AGENCIES FOR NATIONAL ADMINISTRATION}

desire to send to Congress, at the same time that the Book of Estimates was presented by the Secretary of the Treasury, a budget prepared along the lines set forth in his message to Congress of June 27, and directing them to prepare two sets of estimates and summaries of estimates, one in accordance with the existing practice and one substantially in accordance with the forms contained in the report of the Commission on Economy and Efficiency.

This proposal of the President to submit estimates of expenditure needs in a form different from that employed in the past was strongly resented by Congress, which saw in it an attempt on the part of the President to increase his influence in the matter of making provision for the financial needs of the government. It accordingly sought to prevent it by inserting in one of the appropriation bills the following section:

Section 9. That until otherwise provided by law, the regular annual estimates of appropriations for expenses of the Government of the United States shall be prepared and submitted to Congress, by those charged with the duty of such preparation and submission, only in the form and at the time now required by law, and in no other form and at no other time.

The chairman of the Committee on Appropriations, in a speech defending this action, explained that "Congress knew best the character and extent of the information it desired in responding to the demands of the Executive for appropriations . . . that it would not be wise for Congress to abdicate, even by implication, its prerogative in this matter," and that "until it could be determined by careful and deliberate study of the scheme, whether it should be accepted and adopted, it was not deemed wise or provident to have... The time and energies of large numbers of the most capable persons in the several branches of the public service diverted to transforming the entire estimates for the next fiscal year into this new and unauthorized plan of a so-called national budget." 1

The President, however, believing that Congress had no power under the Constitution to prevent him from obtaining from administrative officers such information as he might

${ }^{1}$ Cong. Rec. Aug. 27, 1912, p. I3 and 142. 


\section{EFFORTS FOR ADMINISTRATIVE REFORM}

desire, on September 19, I9I2, sent a letter to the Secretary of the Treasury and copies to all the department heads, calling attention to his instructions of July ro, and defining his attitude with regard to the above-mentioned Section 9, as follows :

Under the Constitution the President is intrusted with the executive power and is responsible for the acts of heads of departments and their subordinates as his agents, and can use them to assist him in his constitutional duties, one of which is to recommend measures to Congress and to advise it as to the existing conditions and their betterment.

If the President is to assume any responsibility for either the manner in which business of the Government is transacted or results obtained, it is evident that he cannot be limited by Congress to such information as that branch may think sufficient for his purpose. In my opinion, it is entirely competent for the President to submit a budget, and Congress cannot forbid or prevent it. It is quite within his duty and power to have prepared and to submit to Congress and to the country a statement of resources, obligations, revenues, expenditures, and estimates in the form he deems advisable. And this power I propose to exercise.

$\mathrm{He}$, therefore, instructed the heads of departments to print and send to Congress the forms of estimates required by it of officers, without delay; also to have sent to him the information asked for in his letter of July IO, I9I2, the latter to be made the basis for review, revision, and summary statement in the form of a budget with supporting documents which he intended to send to Congress by special message.

-These instructions were followed, and on February 26, I9I3, the President sent to Congress a report prepared by the commission under the title of "A Budget for the Fiscal Year I9I4."

This report consisted of four budget statements showing financial condition and operating results, submitted as a basis for considering the present and prospective fiscal condition; eleven summaries of estimates submitted as a basis for considering revenues and expenditures in relation to questions of government policy; and a summary of proposed changes of law, setting forth what legislation it was thought should be enacted in order to enable the administration to transact public 


\section{AGENCIES FOR NATIONAL ADMINISTRATION}

business with greater economy and efficiency. The report contained, furthermore, in the form of appendices, schedules supporting budget statements; a memorandum on the need for the organization of a bureau of central administrative control; reports containing recommendations of officers of the several departments for changes in law affecting the organization, work, personnel, and business methods of the government, prepared in response to special inquiry of the President; a summary of constructive recommendations contained in the annual reports of the executive departments and other establishments; and a list of positions to which appointments are made by the President with the advice and consent of the Senate.

No action was taken by Congress on this report. The effect of the two reports of the commission was thus limited to that of raising in a very concrete form the problem of a national budget and of laying the basis for further consideration of this subject.

Problems of Organization. For years it had been known 4 that conditions in respect to the grouping of services departmentally and the allotment of duties among the services were extremely unsatisfactory, that there was much duplication of organization, plant and work, and that the loss resulting therefrom reached large proportions. The commission accordingly undertook as one of its distinct activities to make a thorough study of the organization and activities of the government, with a view to the formulation of proposals by which conditions might be improved. As an initial step it caused to be prepared a report setting forth in detail the organization of the government as it existed on July I, I9II. This report, which is entitled "Outline of Organization of the United States Government, July I, I9I I," was sent to Congress by the President, accompanied by a letter of transmittal, January I7, I9I2.

This report is noteworthy as representing the first attempt that had ever been made to show in full detail how the government was organized for the performance of its work. Of it the President in his letter of transmittal said:

From these outlines it is possible to determine not only how each department, bureau, and operating unit, such as a 
navy yard, is organized, but also, by classifying these units by character and geographical location, the number of units of a like character that exist at Washington, and the number and character of services of the government in each city or other point in the United States. With this information available, it is possible to study any particular activity or the problem of maintaining services at any given city or point.

Information of this character has never before been available. Administrative officials have been called upon to discharge their duties without that full knowledge of the machinery under their direction which is so necessary to the exercise of effective control; much less have they had information regarding agencies in other services that might be made use of. Under such circumstances each service is compelled to rely upon itself to build up its own organization and to provide its own facilities regardless of those in existence elsewhere.

As a next step in the development of the information needed in order to bring about a better distribution and correlation of the activities and organization units of the government, the commission undertook the preparation of a series of monographs descriptive of the history, activities and organization of the several services of the government. A considerable number of such monographs were completed and published in the reports of the commission as will appear in the list of publications of the commission appended to this chapter.

Thirdly, on the basis of the information thus secured the commission prepared a number of reports recommending the abolition of certain services and the consolidation of certain others. It thus recommended the abolition of the Revenue Cutter Service of the Treasury Department, and the Returns Office of the Department of the Interior, the consolidation of the Bureau of Lighthouses of the Department of Commerce and Labor and the Life Saving Service of the Treasury Department, and the consolidation of the six auditors' offices of the Treasury Department. A special report was also prepared recommending the establishment of an independent health service, by the transfer to that service of the Public Health and Marine Hospital Service of the Treasury Department, the divisions having to do with the protection of public health in 
the Bureau of Chemistry of the Department of Agriculture, the Division of Vital Statistics of the Bureau of the Census in the Department of Commerce and Labor, and such other services as have to do purely with public health work.

These reports were transmitted to Congress by the President with his approval, but no action was taken upon them. They represented but a beginning of the work to be done in this field, the abolition of the commission through the failure of Congress to make provision for its support preventing the work, however, from being carried further.

Problems of Personnel. In this field the commission made studies regarding methods of appointment of officers and employees, methods of keeping efficiency records, and the general problem of the establishment of a proper system for the retirement of superannuated employees. The results of these studies were transmitted to Congress and published as public documents.

Problems of Financial Procedure. A very large amount of work was done by the commission in the way of studying the accounting and reporting systems, not only of the government as a whole, as represented by the system of Treasury accounts, reports and audit, but of the individual services. These studies were of two kinds; one, descriptive, having for its purpose to make known existing practices, the other, constructive, having for its purpose to outline new practices conforming to modern principles of public accounting. Especially was the effort made to bring about a greater standardization in expenditure documents, and in accounting and reporting procedure. Not a little work was also done in working out a classification of objects of expenditures. This classification was intended to serve as a basis for the detailed consideration of questions of standardization of purchases, the development of uniform specifications, the establishment of uniform tests as to quality of articles delivered and for the uniform classification and codification of data contained in documents of expenditures which must be used as a basis for accounting.

Only in small part were the results of these studies published in reports transmitted to Congress and printed as public documents. A considerable number of the constructive studies, having for their purpose to suggest improved methods for the 


\section{EFFORTS FOR ADMINISTRATIVE REFORM}

handling of expenditures and the rendering of accounts, were, however, published in the series of circulars issued by the commission. The titles of these studies can be seen by reference to the list of publications of the commission appended to this chapter. The descriptive studies, though carefully done, were still in manuscript form when the commission went out of existence.

Not a little work was done in the way of putting into effect the recommendations of the commission for the improvement of accounting methods. This took the form partly of the issue by the Comptroller of the Treasury of circulars addressed to accounting officers of the government, directing them to make use of the changed methods suggested by the commission $;^{1}$ and partly of the adoption by the accounting officers of the several services of improvements suggested to them by the commission.

Problcms of Business Practice and Procedure. In this field especial attention was paid to the subjects of the handling and filing of correspondence, the methods employed in distributing government documents, the use of photographic processes for the copying of documents, the use of labor-saving devices and certain other features of business management. In respect to the first, detailed investigations were made regarding not only the handling and filing of correspondence but of methods of business generally of a number of the bureaus of the War Department. The results of all these studies were embodied in reports which were transmitted to Congress and published by that body as public documents. In a considerable number of cases the recommendations of the commission were acted upon.

\section{PUBLICATIONS}

I. Messages of the President and Official Reports of the Commission Submitted to Congress and Printed as Public Documents.

I. Special message of the President of the United States on the President's inquiry into economy and efficiency. I9I I. $6 \mathrm{p}$.

- Same, with title: Message asking appropriation to continue investigation of business methods employed in Executive departments. March 3, I9II. 4 p. (6Ist Cong., 3d sess. Senate. Doc. 859. Serial No. 5943.)

${ }^{1}$ Treasury Circulars, I9II, Nos. 34 and 35 ; 1912, No. 36 . 


\section{AGENCIES FOR NATIONAL ADMINISTRATION}

2. Message of the President of the United States on economy and efficiency in the government service. Communicated to the two houses of Congress January I7, I9I2. $28 \mathrm{p}$.

Same, January I7, I912. 2 v. (62d Cong., $2 \mathrm{~d}$ sess. House.

Doc. 458. Serial No. 6296-7.)

Contents :

Message of the President ... January I7, I9I2, p. I-20.

Appendix: Report to the President on the organization of the government of the United States as it existed July I, I9II, shown by an outline of organization with recommendation regarding its use in the administration of public affairs. . . Submitted by the Commission on economy and efficiency. November, I9I I, p. 2I-I 533 .

3. Commission on economy and efficiency. Message from the President of the United States transmitting information in response to Senate resolution of January 25, I9I2, giving the names of the members of the Commission on economy and efficiency in the Government service. February 5, I9I2. 2 p. (62d Cong., 2d. sess. Senate. Doc. No. 294. Serial No. 6180.)

4. Report of the Commission on economy and efficiency. Message from the President of the United States transmitting reports of the Commission ... relative to centralization of the distribution of government publications, and so forth. February 5, I912. 37 p. 3 fold. pl. (62d Cong., 2 d sess. Senate. Doc. No. 293. Serial No. 6I75.)

\section{Contents :}

Report on the centralization of the distribution of government publications.

Report on the use of window envelopes in the government service.

Report on the use of a photographic process for copying printed and written documents, maps, drawings, etc.

5. Message of the President of the United States on economy and efficiency in the government service, communicated to the two houses of Congress, April 4, I9I2. I2 p.

- Same, with title: Economy and efficiency in the government service. Message of the President of the United States transmitting reports of the Commission on economy and efficiency. April 4, I9I2. 565 p. (62d Cong., 2d sess. House. Doc. 670. Serial No. 6298.)

Contents.

Message of the President, p. I-I4.

Methods of appointment, p. 15-42.

Regulations governing appointments and promotions in the Consular service.

Extract from regulations governing the Public health and marine-hospital service.

Consolidation of Bureau of lighthouses, Department of commerce and labor, and Life-saving service, Department of the Treasury, p. 43-265.

Partial Contents.

Report of the Joint committee on the Life-saving service and the Bureau of lighthouses, I9II. 


\section{EFFORTS FOR ADMINISTRATIVE REFORM}

Statement showing location of life-saving stations in relation to nearest lighthouse.

History, organization, and activities of the Life-saving service.

History, organization, and activities of the Bureau of Lighthouses.

Revenue-cutter service of the Department of the Treasury, p. 267-397. (Contains bibliography.)

Accounting offices of the Treasury, with recommendations for the consolidation of the six auditors' offices into one office, p. 399-420.

Partial Contents.

History of accounting system of Government, 1789 to 1894 . Law reorganizing the accounting offices of the Treasury.

Returns office of the Department of the Interior, p. 421-460.

Travel expenditures, p. 46I-5I4.

Memorandum of conclusions concerning the principles that should govern in the matter of handling and filing correspondence and preparing and mailing communications in connection with the work of the several departments of the government, together with suggestions for the use of laborsaving devices in preparing and mailing letters, etc., p. 5I 5-554.

Vertical flat filing.

Briefing.

Subjective classification of correspondence.

Registers of correspondence.

The press copy versus the carbon copy.

The dictation machine.

Mailing machinery.

The window envelope.

Rearrangement of form blanks.

Elimination of salutation and complimentary close.

Report of test of dictation machine in Post Office department.

Report of Navy department committee.

Report of Treasury department committee.

Report of Department of Agriculture committee.

Report of Post Office department committee.

Report of Department of the Interior committee.

Report of Department of Commerce and labor committee. Centralization of the distribution of government publications. The use of the outline of organization of the government prepared by the Commission as a means for showing currently organization conditions of the government.

6. Retirement from the classified civil service of superannuated employees. Message from the President of the United States transmitting report of the Commission on economy and efficiency on the subject of retirement from the classified civil service of superannuated employees. May 6, I912. 4, 59, 225, 264, 49, 8, 5 p. incl. diagrs. (62d Cong., 2d sess. House. Doc. 732. Serial No. 6299.)

Contents. 


\section{AGENCIES FOR NATIONAL ADMINISTRATION}

Message of the President, 4 p.

Report to the President on retirement allowances. April, I9I2. $59 \mathrm{p}$.

Savings and annuity plan proposed for retirement of superannuated civil service employees, by Herbert D. Brown, 19II. 225 p. (Senate document No. 745. 6Ist Cong., 3 d sess.)

Civil service retirement-Great Britain and New Zealand, by Herbert D. Brown. Prepared under the direction of Chas. P. Neill, commissioner of labor. I9Io. 264 p. (Senate. Doc. No. 290, 6Ist Congress, 2d sess.)

Civil service retirement-New South Wales, Australia. By Herbert D. Brown. Prepared under the direction of Chas. P. Neill, commissioner of labor. I9Io. 49 p. (Senate. Doc. No. 420, 6ist Congress, 2d sess.)

The Hamill, Maher, and Cummins bills. 8 p.

Schedule calling for information with regard to employees. 5 p.

7. The need for a national budget. Message from the President of the United States transmitting report of the Commission ... on the subject of the need for a national budget. June 27, I9I2. 568 p. (62d Cong., 2 d sess. House. Doc. No. 854. Serial No. 6300.)

Contents.

Message of the President, p. I-5.

The need for a national budget.

Historical and descriptive, p. I3-I28.

Discussion of constructive recommendations by the Commission, p. 129-224.

Pro forma budget and supporting documents, p. 225-385.

Digest of laws governing the preparation and submission of estimates, p. 389-407.

Digest of laws pertaining to appropriations and allotments, p. 409-38.

Description of reports at present submitted to Congress by the several departments and establishments, p. 439-75.

Bibliography of Congressional inquiries into the conduct of the business of executive departments, other than by standing committces of Congress, I789-I9II, p. 477-85.

Answers to questionnaire on budget methods and procedure in $[38]$ foreign countries, prepared by the Commission and returned by foreign representatives, p. 487-568.

8. Report of the investigation of the United States Patent Office, made by the President's commission on economy and efficiency. December 9, I912. 624 p. (62d Cong., 3d sess. House. Doc. No. i I Io. Serial No. 6469.)

Contents.

Message of the President, p. 7.

Report and recommendations, p. 9-210.

Administration.

Methods of examining applications.

Interference procedure.

Classification division. 


\section{EFFORTS FOR ADMINISTRATIVE REFORM}

The scientific library and the search room.

Personnel of the Patent Office.

Building accommodations and office equipment.

Publications.

Term of patent and delays.

Fees, revenues, and expenditures.

Miscellaneous.

Views of patent attorneys.

Subjects not reported on.

History of the United States patent system, p. 2I I-40.

United States laws and rules of practice relating to patents, trade-mark, and print and labels, p. 24I-320.

The German patent law, p. 32I-31.

The English patent law, p. 333-67.

Discussion of the German patent law and patent procedure, p. 369-410.

A comparison of the patent laws and procedure in Germany,

England, and the United States, p. 4I I -43 .

Methods of examining applications, p. 445-73.

Publications of the Patent Office, p. 475-95.

Statement of the business of the Patent Office, p. 497-5I8.

Bibliography of the United States Patent Office, p. 519-35.

Classification of patents and printed publications, p. 537-624.

9. Message of the President of the United States transmitting the reports of the Commission on economy and efficiency, January 8, I9I3. X, 923 p. (62d Cong., 3d sess. House. Doc. No. 1252. Serial No. 6470.)

The Message of the President was published also in Circular No. 3I, of the Commission.

Contents.

Message of the President, p. I-6.

Letter of the Secretary of War, p. 7-9.

Report to the President on the work of the Commission, p. II-38.

Business methods of the office of the Adjutant General, War Department, p. 39-480.

Contents:

A brief on the legal aspect of the carbon copy as compared with the press copy, p. 476-48o.

The handling and filing of correspondence in the Mail and record division of the Office of the Chief of engineers, $p$. $48 \mathrm{I}-502$.

The handling and filing of correspondence and the doing of statistical work in the Bureau of insular affairs, p. 503-64.

The handling and filing of correspondence in the Office of the Surgeon general, p. 565-97.

The handling and filing of correspondence in the Office of the Signal corps, p. 599-621.

The handling and filing of correspondence in the Office of the Chief of ordnance, p. 623-30.

The handling and filing of correspondence in the Mail and record division of the Department of Justice, p. 63I-753. 
Methods of keeping efficiency records of employees in the National bank redemption agency of the Department of the Treasury, p. 755-98.

Report on the electric lighting of federal buildings of the Department of the Treasury, p. 799-908.

On the establishment of an independent public health service, p. 909-1 5 .

The recovery of fiber stock of canceled paper money, p. 917-23.

Io. Underground pneumatic tube system. Hearing before the Committee on public buildings and grounds, United States Senate, Sixty-second Congress, third session ... Report of the President's Commission on economy and efficiency, January 9, I9I3. $6 \mathrm{p}$.

This is Part II of the Hearings on Underground pneumatic tube system. Part I consists of the Hearing of June 7, 1912.

II. Recovery of government waste-paper. Message from the President of the United States, submitting in response to Senate resolution of February 2I, I9I3, additional information relative to the saving in recovery of government waste-paper. February 24, 19I3. I 8 p. (62d Cong., 3d sess. Senate. Doc. No, 1105. Serial No. 6365.)

12. Message of the President of the United States submitting for the consideration of the Congress a budget, with supporting memoranda and reports. February 26, 1913. 433 p. (62d Cong., 3d sess. Senate. Doc. No. III3. Serial No. 6353.)

Partial Contents.

7 Memorandum on the need for the organization of a Bureau of central administrative control, p. 187-205.

Reports containing recommendations of officers of the several departments for changes in law affecting the organization, work, personnel, and business methods of the government, p. 207-335.

Summary of constructive recommendations contained in the annual reports of the executive departments and other establishments, p. 337-90.

List of positions to which appointments are made by the President with the advice and consent of the Senate, p. 39I-433.

\section{Circulars Printed by the Commission}

No. I. Outline for the reclassification of estimates of government expenditures on a uniform basis. 19I0. 13 p.

No. 2. Tentative outline for the reclassification of objects of government expenditures on a uniform basis with a detail classification and codification of war equipment. 1910. 22 p.

No. 3. Tentative outline and numbering of the several bureaus and division of the Navy, prepared by the Committee on economy and efficiency of the Department of the Navy. 1911. $16 \mathrm{p}$. 


\section{EFFORTS FOR ADMINISTRATIVE REFORM}

No. 4. Interim report on plan of inquiry and progress of work from September 27 to December 31, I9ro. I9II. $33 \mathrm{p}$.

No. 5. Questions to be answered and memorandum of instructions to be followed in the preparation of report (form 6) asked for on the subject of the handling and filing of correspondence. I9II. I3 p.

No. 6. Description of expenditure documents and procedure for the purchase of supplies, materials, equipment, and services other than personal and for the distribution of supplies and materials from stores. IgII. $50 \mathrm{p}$. incl. forms.

No. 7. (Not printed.)

No. 8. Definition and classification of expenditures for services other than personal-transportation of persons. I9II. $3.3 \mathrm{p}$.

No. 9. Definition and classification of expenditures for services other than personal-subsistence and support of persons. I9II. 2 I p.

No. ro. Revised outline for the reclassification of objects of government expenditures on a uniform basis. I9II. 20 p. (Revision of Circular 2.)

No. II. Outline illustrating the use of a uniform classification of stationery, drafting, scientific and educational supplies for the purpose of correlating specification numbers with a code for common analysis of accounts. I9II. $30 \mathrm{p}$.

No. I2. Catalogue and price list of supplies for use in the Bureau of the Census. Department of Commerce and Labor. I9II. I3 $\mathrm{p}$.

No. 13. Description of accounting forms suggested as a means of - obtaining the information needed about appropriations and funds, stores, expenses, capital outlays, etc. I9II. I4 p. I3 fold. forms.

No. I4. Proposed business and accounting procedure of the United States Indian Service, Department of the Interior, submitted through the Committee on economy and efficiency of the Department of the Interior. I9II. I7 p. 20 forms.

No. I5. Questions to be answered and instructions to be followed in the preparation of report asked for on the subject of the collection of cost data, the keeping of cost accounts, and the making of cost reports. I9II. $22 \mathrm{p}$.

No. 16. Circular in re reports to be prepared by committees on economy and efficiency of the executive deartments and independent establishments regarding (I) Action taken during the present administration looking to the effecting of economies and increased efficiency, (2) Publications being issued by the executive departments and establishments, (3) Departmental and bureau libraries. IgIr. $20 \mathrm{p}$.

No. 17. Organization charts of the Department of the Navy. Prepared as part of a report on the organization of the government of the United States as shown by outlines of organization, charts and maps. IgII. 3 p. 36 charts.

No. 18. Suggestions as to schedules of documents and registers of documents and schedules for use in developing a uniform 


\section{AGENCIES FOR NATIONAL ADMLNISTRATIDN.}

system of controlling accounts and summary reports. I9II. 16 p. incl. forms.

No. I9. Outline of classification of objects of government expenditure on a uniform basis, with symbols for convenient reference to price lists and catalogues. I9II. I3I p.

No. 20. Suggested forms for reporting assets and liabilities, revenues and expenses, funds and appropriations together with definitions of governmental accounting and reporting terms. I9I. $21 \mathrm{p}$. incl. forms.

No. 21. Memorandum of conclusions reached by the Commission concerning the principles that should govern in the matter of handling and filing correspondence and preparing and mailing communications in connection with the work of the several departments of the government, together with suggestions for the use of labor-saving devices in preparing and mailing letters, etc. I9I2. 36 p.

Same. Revised edition. I912. 42 p.

No. 22. Report to the President on the use of the outline of organization of the government, prepared by the Commission as a means for showing currently organization conditions of the govermment. I9I2. $8 \mathrm{p}$.

No. 23. Memorandum concerning the work completed and in progress by the President's Commission ... submitted for the information of the Committee on appropriations of the House of Representatives. I9I2. 18 p.

No. 24. Questions to be answered and memorandum of instructions to be followed in the preparation of report (Form 6) asked for on the subject of the keeping of service records and the preparation and payment of pay rolls, etc. II p. (Manuscript.)

No. 25. Instructions to be followed in the preparation of analyses of estimates and expenditures called for by the President, July I0, I9I2. 1912. 9 p.

No. 26. Report to the President recommending the preparation of alphabetical lists or catalogues to be used in the several branches of the service in the preparation of requisitions, orders and other expenditure documents. I9I2. $22 \mathrm{p}$.

No. 27. Instructions to be followed in the analysis of salaries and wages by classes of employees and other compensation for personal services paid by the government of the United States. I9I2. 24 p.

No. 28. Questions to be answered and instructions to be followed in the preparation of report asked for on the subject of telegraph and cable business and cipher coding systems. I9I3. 8 p.

No. 29. Report on the preliminary inquiry made under authority of the Sundry civil appropriation act of June 25, 1910, prior to the organization of the President's Commission on economy and efficiency. [September 27, I9I0, to March 8, I9II.] I9I3. I8 p.

No. 3o. Report to the President by the Commission on economy and efficiency. [Oct. 30, I9II.] I9I3. $32 \mathrm{p}$.

No. 3I. Message of the President transmitting reports of the Com- 


\section{EFFCRTS FOR ADMINISTRATIVE REFORM}

mission on economy and efficiency, January 8, I9I3, together with a brief memorandum descriptive of the work of the Commission since its organization. 1913. I9 p.

Published also in House Doc. No. 1252, 62d Cong., 3d sess. Serial No. 6470.

No. 32. The administrative purpose of the accounting methods and procedures which have been installed in the departments. 1913. I3 p.

No. 33. Conclusions reached with respect to expenditure accounting and reporting. A discussion of the information needed and of the methods recommended as a means of producing it. 1913. 53 p. illus.

No. 34. Report by the Commission on economy and efficiency submitted to the President, December 18, 1912, and sent to Congress with the message of the President, January 8, I913. I913. $28 \mathrm{p}$.

Published also in House Doc. No. 1252, 62d Cong., 3d sess. Serial No. 6470.

No. 35. Report on methods of keeping efficiency records of employees in the National Bank Redemption Agency of the Department of the Treasury. 1913. $44 \mathrm{p}$.

\section{Miscellaneous Documents bearing upon the Work of the Commission}

1. Hearings before Committees of Congress.

Statement of [Charles D. Norton] the Secretary to the President, concerning the President's Inquiry in re Economy and Efficiency, before the subcommittee of the House Committee on Appropriations .... Feb. 6, I9II. I6 p.

Hearings before subcommittee of House Committee on Appropriations .... in charge of Sundry Civil Appropriation Bill for I913, relating to the President's Commission on Economy and Efficiency. 1912. 35-175 p.

Hearings before subcommittee of House Committee on Appropriations in charge of Sundry Civil Appropriations Bill for 19I4, relating to the President's Commission on Economy and Efficiency, and before sub-committee of Senate Committee on Appropriations, relating to certain reports of the Commission affecting items in the legislative, executive and judicial appropriation bill for 1914. January Io and I3, 1913. $75 \mathrm{p}$.

Underground pneumatic tube system. Hearing before the Committee on Public Buildings and Grounds, United States Senate, Sixty-second Congress, third session . . . Report of the President's Commission on Economy and Efficiency. January 9, 19I3. $6 \mathrm{p}$.

This is Part II of the Hearings on Underground pneumatic tube system. Part I consists of the Hearing of June 7, 1912.

2. Letter of the President to the Secretary of the Treasury.

Copy of letter by the President to the Secretary of the Treasury, relative to the submission of a budget to Congress. Sept. 19, 1912. 8 p. 


\section{AGENCIES FOR NATIONAL ADMINISTRATION}

3. Treasury Circulars.

Department Circular No. 34. I9II. The principles which should govern expenditure accounting and reporting in the several departments after July I, I9II. June 20, I9II. 3 p.

Department Circular No. 35. I9II. Principles governing the forms of expenditure documents and the character of evidence to be prepared and kept pertaining to transactions involving the expenditure of public money. May 20, I9II. $2 \mathrm{p}$.

Department Circular No. 36. I9I I. Definitions of classes of expenditures outlined in Circular No. 34 (revised), governing expenditure accounting and reporting. June 2I, I9II. II $p$.

Department Circular No. 27. I912. Transportation of government employees and property. June 15, I9I2. $3^{8} \mathrm{p}$. 
United States Bureau of Efficiency, I9I3. The United States Bureau of Efficiency may be looked upon, in a measure, as a successor of the President's Commission on Economy and Efficiency. At the time the commission went out of existence it had under investigation the subject of the establishment in the government services of systems for the determination of the efficiency with which employees performed their duties. Though declining to continue the commission, Congress was desirous that this work should be proceeded with. It accordingly inserted in the legislative, executive and judicial appropriation act for I9I3, approved August 23, I9I2, the following clause providing for the continuance of this work under the auspices of the Civil Service Commission.

The Civil Service Commission shall, subject to the approval of the President, establish a system of efficiency ratings for the classified service in the several executive departments in the District of Columbia based upon records kept in each department and independent establishment with such frequency as to make them as nearly as possible records of fact. Such system shall provide a minimum rating of efficiency which must be attained by an employee before he may be promoted; it shall also provide a rating below which no employee may fall without being demoted; it shall further provide for a rating below which no employee may fall without being dismissed for inefficiency. All promotions, demotions, or dismissals shall be governed by provisions of the civil service rules. Copies of all records of efficiency shall be furnished by the departments and independent establishments to the Civil Service Commission for record in accordance with the provisions of this section: Provided, That in the event of reductions being made in the force in any of the executive departments no honorably discharged soldier or sailor whose record in said department is rated good shall be discharged or dropped, or reduced in rank or salary.

Due to the fact that no appropriation was made for this work, the Civil Service Commission was unable ta take any active steps looking to the carrying out of this direction. 


\section{AGENCIES FOR NATIONAL ADMINISTRATION}

This omission was corrected by the legislative, executive and judicial appropriation act for 19I4, approved March 4, I9I3, the clause carrying the appropriation reading as follows :

Establishment and maintenance of system of efficiency ratings for initial year: For the establishment and maintenance of system of efficiency ratings for initial year, \$, I 5,000, to be immediately available. The Civil Service Commission shall investigate and report to the President, with its recommendations, as to the administrative needs of the service relating to personnel in the several executive departments and independent establishments in the District of Columbia, and report to Congress details of expenditure and of progress of work hereunder at the beginning of each regular session: Provided, That no person shall be employed hereunder at a compensation in excess of $\$ 4,000$ per annum.

This appropriation being immediately available the Civil Service Commission at once, i.e., March 25, I9I3, established a Division of Efficiency to have charge of the work and placed at its head $\mathrm{Mr}$. Herbert $\mathrm{D}$. Brown, who, as a member of the staff of the President's Commission on Economy and Efficiency, had had the direction of work in this field by that body.

The continuance of this work was authorized by the legislative, executive and judicial appropriation bill for I9I5, approved July I6, I9I4, which made an additional grant of $\$ 30,000$ for this purpose. Since the clause making this appropriation reads substantially as that for the previous year, it is not here reproduced.

The legislative, executive and judicial appropriation act for 1916, approved March 4, I9I5, likewise appropriated \$30,ooo for the work, but in doing so made two innovations which are of importance. The first is that the appropriation was made in the form of a grant for the maintenance of a service instead of the mere prosecution of a piece of work, and thus, in effect, established a permanent service. The second is that the duties of this service were enlarged so as to cover not only the establishment of efficiency ratings, but "investigation of the needs of the several executive departments and independent establishments with respect to personnel; and for in- 


\section{EFFORTS FOR ADMINISTRATIVE REFORM}

vestigation of duplication of statistical and other work and methods of business in the various branches of the government service." It will be seen, therefore, that the service was in effect given the broad functions of an efficiency service. Following is the clause making this provision:

Division of Efficiency: For establishment and maintenance of system of efficiency ratings, pursuant to section four of the legislative, executive, and judicial appropriation Act for the fiscal year nineteen hundred and thirteen, for investigation of the needs of the several executive departments and independent establishments with respect to personnel; and for investigation of duplication of statistical and other work and methods of business in the various branches of the Government service; including not more than $\$ 2,500$ for equipment, supplies, stationery, books, and printing; and not more than $\$ 50$ for street car fare, $\$ 30,000$; the chief of the Division of Efficiency herein provided for shall be appointed by the President and shall report to Congress at the beginning of each regular session, through the President, the nature and progress of work undertaken by the division together with a detailed statement of expenditures showing the persons employed, their duties, and the compensation paid to each: PROVIDED, That no person shall be employed hereunder at a compensation in excess of $\$ 4,000$ per annum.

The urgent deficiency act for 1916, approved February 28, I9I6, besides making a further appropriation of $\$ 1,200$ for the division, made the additional important change of taking the division from under the Civil Service Commission and erecting it into an independent establishment under the name of "Bureau of Efficiency." This was done by the following clause :

Bureau of Efficiency: For investigating duplication of statistical and other work in the various branches of the Government service, \$1,200: Provided, That hereafter the Division of Efficiency of the Civil Service Commission shall be an independent establishment and shall be known as the Bureau of Efficiency; and the officers and employees of the said division shall be transferred to the Bureau of Efficiency without reappointment, and the records and papers pertaining to the work of the said division and the furniture, equipment, 


\section{AGENCIES FOR NATIONAL ADMINISTRATION}

and supplies that have been purchased for it shall be transferred to "the said bureau: AND PROVIDED FURTHER, That the duties relating to efficiency ratings imposed upon the Civil Service Commission by section four of the legislative, executive, and judicial appropriation act approved August twenty-third, nineteen hundred and twelve, and the duty of investigating the administrative needs of the service relating to personnel in the several executive departments and independent establishments, imposed on the Civil Service Commission by the legislative, executive, and judicial appropriation Act approved March fourth, nineteen hundred and thirteen, are transferred to the Bureau of Efficiency.

The legislative, executive and judicial appropriation act for I9I7, approved May Io, 1916, raised the annual appropriation of the bureau to $\$ 40,000$ and expressed its powers and duties as an efficiency service in still broader terms. The clause providing for the bureau reads:

Bureau of Efficiency: To enable the Bureau of Efficiency, authorized by the urgent deficiency appropriation Act approved February twenty-eighth, nineteen hundred and sixteen, to establish and maintain a system of efficiency ratings, to investigate administrative needs of the service relating to personnel in the several executive departments and independent establishments, required by the legislative, executive and judicial appropriation Acts for the fiscal years nineteen hundred and thirteen and nineteen huindred and fourteen, respectively, and to investigate duplication of statistical and other work and methods of business in the various branches of the Government service; for purchase or exchange of equipment, supplies, stationery, books and periodicals, printing and binding, traveling expenses not exceeding $\$$ Ioo, and street car fare not exceeding $\$ 50$; in all, \$40,000: Provided, That no person shall be employed hereunder at a compensation exceeding $\$ 4,000$ per annum.

By Senate resolution of May 16, 1916, the bureau was directed to prepare and submit to the Senate estimates of the immediate and ultimate cost of pensioning the civil employees of the government.

By act of Congress, approved May 18, r916, making appropriations for the support of the Bureau of Indian Affairs 


\section{EFFORTS FOR ADMINISTRATIVE REFORM}

for I9I7, the Bureau of Efficiency was directed to prepare and submit to the Secretary of the Interior a system of bookkeeping and accounting for the bureau. This was done by the following clause:

Section 38. On or before the thirty-first day of December, nineteen hundred and sixteen, the Bureau of Efficiency shall prepare and submit to the Secretary of the Interior a system of bookkeeping and accounting for the Bureau of Indian Affairs that will enable the said Secretary, on or before July first, nineteen hundred and seventeen, to meet the requirements of section twenty-six of the Indian Appropriation Act approved June thirtieth, nineteen hundred and thirteen (Thirty-eighth Statutes at Large, page one hundred and three). ${ }^{1}$

In the same year Congress, by the act of September 8, I9I6, making provision for deficiencies for the year 1916, reappropriated the sum of $\$ 4,000$, which had been granted by the deficiency act of March 4, I9I5, for the development of mechanical means for writing and auditing checks in payment of pensions, and directed the Bureau of Efficiency to make

${ }^{1}$ The act of June 30,1913 , provides as follows:

Section 26. On or before the first day of July, nineteen hundred and fourteen, the Secretary of the Interior shall cause a system of bookkeeping to be installed in the Bureau of Indian Affairs, which will afford a ready analysis of expenditures by appropriations and allotments and by units of the service, showing for each class of work or activity carried on, the expenditures for the operation of the service, for repairs and preservation of property, for new and additional property, salaries and wages of employees, and for other expenditures. Provision shall be made by the Secretary of the Interior for further analysis of each of the foregoing classes of expenditures, if, in his judgment, he shall deem it advisable.

Annually, after July first, nineteen hundred and fourteen, a detailed statement of expenditures, as hereinbefore described, shall be incorporated in the annual report of the Commissioner of Indian Affairs and transmitted by the Secretary of the Interior to Congress on or before the first Monday in December.

Before any appropriation for the Indian Service is obligated or expended, the Secretary of the Interior shall make allotments thereof in conformity with the intent and purpose of this Act, and such allotments shall not be altered or modified except with his approval.

After July first, nineteen hundred and fourteen, the estimates for appropriations for the Indian Service, submitted by the Secretary of the Interior, shall be accompanied by a detailed statement, classified in the manner prescribed in the first paragraph of this section, showing the purposes for which the appropriations are required. 
a general investigation of the business methods of the Bureau of Pensions, and also directed that the bureau should investigate the methods of transacting business in the Bureau of Internal Revenue. The sections of the act covering these points read:

Bureau of Efficiency: The sum of $\$ 4,000$ appropriated by the deficiency appropriation Act, approved March fourth, nineteen hundred and fifteen, for the purchase, rental, exchange, and remodeling of labor-saving machinery, equipment, and supplies necessary to enable the Bureau of Efficiency to demonstrate an improved system of paying pensions is reappropriated and made available for expenditure during the fiscal year nineteen hundred and seventeen; Provided, That the equipment purchased hereunder shall become the property of the Bureau of Pensions when the demonstration is completed; Provided Further, That the Bureau of Efficiency shall investigate the business methods of the Bureau of Pensions and prepare recommendations for the improvement thereof and submit the same to the Secretary of the Interior as early as practicable for his approval.

Not exceeding $\$ 3,000$ of the appropriation for the Bureau of Efficiency made in the legislative, executive, and judicial appropriation Act for the fiscal year nineteen hundred and seventeen may be used by the bureau for necessary traveling expenses incurred and to be incurred in carrying out section twenty-eight of the Indian appropriation Act for the fiscal year nineteen hundred and seventeen and performing other duties imposed upon it by law.

The Bureau of Efficiency shall investigate the methods of transacting the public business in the Bureau of Internal Revenue and prepare recommendations for the improvement thereof and submit the same to the Secretary of the Treasury as early as practicable for his approval and to Congress at its next session.

The legislative, executive and judicial appropriation act for 1918, approved March 3, 1917, not only raised the annual grant for the support of the bureau to $\$ 60,000$ and confirmed its general powers, but imposed upon the bureau the performance of a number of highly important tasks. These sections of the act read: 


\section{EFFORTS FOR ADMINISTRATIVE REFORM}

To enable the Bureau of Efficiency, authorized by the urgent deficiency appropriation Act, approved February twenty-eighth, nineteen hundred and sixteen, to establish and maintain a system of efficiency ratings, to investigate administrative needs of the service relating to personnel in the several executive departments and independent establishments, required by the legislative, executive, and judicial appropriation Acts for the fiscal years nineteen hundred and thirteen and nineteen hundred and fourteen, respectively, and to investigate duplication of statistical and other work and methods of business in the various branches of the Government service; for purchase or exchange of equipment, supplies, stationery, books and periodicals, printing and binding, traveling expenses not exceeding $\$ 3,000$, and street car fare not exceeding $\$ 50$; in all, $\$ 60,000$ : Provided, That no person shall be employed hereunder at a compensation exceeding $\$ 4,000$ per annum.

The Bureau of Efficiency shall investigate the methods of examining and auditing claims against the United States and accounts of disbursing officers, and of accounting for receipts and disbursements and shall submit a report to the Secretary of the Treasury and to Congress, with recommendations, at its next regular session.

The Bureau of Efficiency shall investigate the work performed by the Subtreasuries and report to the Secretary of the Treasury and to Congress at the beginning of the next regular session what part of the work of the Subtreasuries may be transferred to other offices of the government; banks of the Federal Reserve System or Farm Loan Banks, and for the purpose of this investigation the representatives of the Bureau of Efficiency shall have access to all necessary books and other records of the government.

The Bureau of Efficiency shall investigate the methods of transacting the public business in the Civil Service Commission and report to Congress through the President at the next regular session of Congress. The officers and employees of the Civil Service Commission are hereby directed to furnish said bureau with such information as it may require to carry out this provision.

The Bureau of Efficiency shall ascertain the rates of pay of employees of various State and municipal governments and commercial institutions in different parts of the United States and shall submit to Congress at its next regular session a re- 
port showing how such rates compare with the rates of pay of employees of the Federal Government performing similar services.

Officers and employees of the executive departments and other establishments shall furnish authorized representatives of the Bureau of Efficiency with all information that the bureau may require for the performance of the duties imposed on it by law, and shall give such representatives access to all records and papers that may be needed for that purpose.

The Bureau of Efficiency shall investigate the classification, salary, and efficiency of the employees of the Departments and Independent Establishments of the government in the District of Columbia and report fully or partially to Congress by January first, nineteen hundred and eighteen, as to needed equalization or reclassification, and if a partial report be submitted then a full report shall be submitted as soon thereafter as possible with such recommendations as the bureau may deem proper. $^{1}$

The importance of this bureau is such that we have thought it worth while to give its legislative history in detail. From it, it will be seen that not only has the bureau been given exceedingly broad powers in respect to the making of investigations having for their purpose the effecting of economy and efficiency in the administration of the national government, but that Congress made free use of the service as an agent to undertake specific lines of work which it believed should be done. In fact, thus the bureau, notwithstanding that its legal status is that of a part of the administrative branch of the government, is functioning largely as a direct agent of the legislative branch.

It is not feasible for us to attempt anything like a detailed statement of the work that has actually been done by the bureau. The bureau has published two administrative reports, one covering the period from March 25, I9I3, to October 3I, 19I6, and the other from the latter date to October 3 I, I9I7. From these reports it is possible for the persons interested to learn the extent to which the bureau has been able to complete its program. It is of course evident that the general duties of the bureau are of a character that will require years of

${ }^{1} 39$ Stat., 1080. 
work for their adequate performance, if, indeed, they can ever be definitely concluded.

In addition there was conferred upon the bureau a sweeping general power to "investigate duplication of service" throughout the government, and the President was authorized, but only after report of such duplication should have been made by the bureau, "to abolish the same." This section reads : ${ }^{1}$

The Bureau of Efficiency shall investigate duplication of service in the various executive departments and establishments of the Government, including bureaus and divisions, and make a report to the President thereon, and the President is hereby authorized, after such report shall have been made to him, wherever he finds such duplications to exist to abolish the same. Report of the action taken hereunder shall be made to Congress at its next regular session.

\section{PUBLICATIONS}

Accounting system for the United States Indian service, by Victor G. Croissant ... James A. Councilor ... James V. Brownell ... I917. 190 p. incl. tables, diagrs., forms.

At head of title: Department of the interior. Office of Indian affairs.

Report of the United States Bureau of efficiency for the period from March 25, 1913, to October 3I, I9I6. 1917. $27 \mathrm{p}$.

Issued also as House Doc. I793, 64th Cong., 2d sess.

Report of the United States Bureau of efficiency for the period from November I, I9I6, to October 31, 1917. 1918. I7 p.

Issued also as House Doc. 901, 65th Cong., 2d sess.

Work performed by the subtreasuries. Letter from the Chief, Bureau of efficiency, transmitting report of the U. S. Bureau of efficiency covering the work performed by the subtreasuries. 1918. $39 \mathrm{p}$. (65th Cong., $2 \mathrm{~d}$ sess. House. Doc. No. 867.)

Partial Contents.

Plan to consolidate subtreasuries of the United States with federal reserve banks.

History [of the Subtreasury system].

Deficiency appropriation-Bureau of efficiency ... a supplemental estimate of appropriation for the fiscal year 1918. Jan. 3, 1918. I p. (65th Cong., 2d sess. House. Doc. No. 735.)

Bureau of efficiency employees. Letter from the Chief, Bureau of efficiency, transmitting statement showing in detail the number of employees of the Bureau ... whose compensation was increased by section 7, appropriation act approved March 3, 1917. Jan. 26, 1918. I p. (65th Cong., 2d sess. House. Doc. No. 870.)

${ }^{1} 39$ Stat., II22. 


\section{AGENCIES FOR NATIONAL ADMINISTRATION}

Travel expense, Bureau of efficiency. Letter from the Chief, Bureau of efficiency, transmitting statement showing in detail what officers and employees of the United States Bureau of efficiency have traveled on official business from Washington to points outside the District of Columbia during the fiscal year ended June 30, 1917. 2 p. (65th Cong., 2d sess. House. Doc. No. 869.) 


\section{CHAPTER III}

\section{AGENCIES FOR INVESTIGATING THE ADMINIS- TRATION OF PARTICULAR STATES: OFFICIAL}

As in the case of the national government, spasmodic efforts have always been made by our state governments to improve particular features of their administration. It was not until the last decade, however, that these governments have attempted anything like a general inquiry into the character of their administrative organizations and methods with a view to the introduction of changes of a general or fundamental character. This action has taken the form of the establishment by law of bodies to which have been generally given the name of economy and efficiency commissions with the broad duty of investigating existing administrative conditions and recommending to the legislature changes in them which in their opinion would lead to greater administrative efficiency and economy.

The creation of these bodies was undoubtedly suggested by the establishment and work of the President's Commission on Economy and Efficiency and the general movement for efficient administration so effectively promoted by the privately established and maintained bureaus of municipal research. These commissions have naturally varied somewhat in their character. Some consisted simply of members of the two houses of the legislature; others provided for the appointment of private individuals who were believed to have special competence in administrative matters. The value of their work has correspondingly varied. Some have been able to do little more than formulate general recommendations. Others have been in a position to make detailed studies, not only of organization conditions, but of technical processes, and to suggest changes of a far-reaching character.

Due to the fact that these commissions in most cases have 
been temporary bodies, and have had only limited funds at their disposal, they have been able to prepare only general reports giving the results of their inquiries and findings. In regard to most of them, little is, therefore, to be noted beyond the fact of their establishment, their purpose as declared by the statutes creating them, and the citations of the report and recommendations made by them.

New Jersey: Economy and Efficiency Commission. The first state to provide for the establishment of a special commission to consider the putting of the administrative system of the state upon a more efficient and economical basis was New Jersey. By a joint resolution, approved April I, I9 I $2^{1}$ provision was made for the creation of a commission of seven members, two of whom were to be members of the Senate, appointed by the President of the Senate; two members of the House of Assembly, appointed by the Speaker of the House; and three citizens of the state of New Jersey, appointed by the Governor, which should have the duty "of considering the best means to consolidate various boards and to broaden the powers in one central board or boards." The full title of this commission was "Commission upon the Reorganization and Consolidation of Different Departments of the State Government whose Functions are Interrelated." It is usually known, however, and is in fact so designated in official communications by the shorter title of "Commission on Economy and Efficiency."

At the close of the session of I9I3, an appropriation was made by the legislature for the continuance of the work of the commission and subsequent appropriations have enabled the commission to continue its work. A clerk to the commission and a stenographer devote a portion of their time to the commission's work. At times efficiency engineers have been employed to study methods and practices in the state and to make recommendations to the commission.

Since the organization of the commission in I9I2 the members have devoted much of their time to an examination and study of the powers and duties of the various state departments, boards, commissions and officials, and charts of

${ }^{1}$ Joint Resolution No. 6, New Jersey, Acts, 1912, p. 945-946. 


\section{EFFORTS FOR ADMINISTRATIVE REFORM}

organization have been prepared showing graphically the present state government and its various ramifications and setting forth what consolidations can be effected. For a time a secretary devoted his entire time to the collection and tabulation of data about each state agency, and to the preparation for the members of the commission of comparisons between the New Jersey and other state governments. The commission also keeps in touch with similar organizations in other states.

In accordance with the terms of the resolution creating it, the commission has devoted its chief attention to the matter of the reorganization of the administrative services of the state. Constitutionally, New Jersey has the great advantage of an administrative system of the integrated type. The benefits of this system had, however, in large part been lost by the creation of an excessive number of separate agencies. "It has been the practice in this state to organize a separate commission for each new phase of work. It has been carried to such an extent that we venture to say that if in the opinion of the Legislature it was advisable to have a state park in each county, instead of organizing one department to acquire the land and to develop and care for the parks, twenty-one commissions would be organized, twenty-one secretaries would be secured and twenty-one staffs of engineers and clerks would be employed."1

The commission accordingly applied itself to the task of studying each of these bureaus, boards and commissions with a view to determining the extent to which they could be consolidated or logically grouped in departments.

Early in I9I3, it submitted a report to the legislature recommending: (I) the consolidation of the State Board of Assessors and the Board of Equalization; (2) the abolition of the separate shell-fish commissions and their consolidation under a central bureau of game and fisheries; (3) the reorganization of the Department of Labor, the Bureau of Labor Statistics and the Employees Liability Commission; (4) the consolidation of the offices of Comptroller of the Treasury and the Department of Accounts; and (5) the union of the

${ }^{1}$ Second Report of the Commission upon the Reorganization and Consolidation of Different Departments of the State Government whose Functions are Interrelated, I9I4, p. I3. 


\section{AGENCIES OF PARTICULAR STATES, OFFICIAL}

Department of Inland Waterways and the New Jersey Canal Commission. Following these recommendations various bills were introduced, but only one was enacted, that providing that the Department of Accounts be consolidated with the office of the Comptroller of the Treasury. This resulted in greater efficiency and an audit before, instead of after, the disbursement of state moneys.

In 1914 , the commission proposed a more comprehensive plan for reconstructing certain branches of the state administration. It recommended the creation of seven new departments, each to be formed by the reorganization and consolidation of boards and commissions, which were at the time performing functions of a similar nature largely independent of one another. The new departments recommended and the estimated annual net economies to be effected in each case were as follows: Department of Health, \$24,224; Department of Shell Fisheries, \$3,800; Department of Taxation, $\$ 40,500$; Department of Conservation and Development, $\$ 28,823.5^{\circ}$; Department of Commerce and Navigation, \$10,800; Department of Prison Control, $\$ 22,663.59$; Board of Public Utilities, $\$ 6,000$. The total net annual economies to be effected by the adoption of these recommendations were thus estimated to be nearly $\$ 147,000$. The reorganization of the Department of Labor was also recommended in a special report.

These recommendations were in large part approved by the legislature.

The reorganization of the State Board of Health, the consolidation of the various oyster commissions, the consolidation of the State Board of Taxation and the State Board for the Equalization of Taxes, the creation of the Department of Conservation and Development, superseding the Forest Park Reservation Commission, the Geological Survey, several park commissions and the State Water Supply Commission after July I, I9I6, the establishment of the Department of Commerce and Navigation, which takes over the duties of the former Department of Inland Waterways, the New Jersey Ship Canal Commission, the Commission on Port Conditions, Obstructions to Navigation and Inspection of Power Vessels, the consolidation of the Bureau of Labor Statistics with the 


\section{EFFORTS FOR ADMINISTRATIVE REFORM}

Department of Labor-these represent in part the work of this commission during the past year. ${ }^{1}$

The fourth annual report of the commission made to the General Assembly, in I9I6, dealt with the State Tenement House Commission and the concentration of purchases for the use of the state and state institutions. With regard to the Tenement House Commission it was recommended that the cost of the commission to the state "be limited to those expenses necessarily incident to the maintenance of the required organization, viz., salaries and expenses of commissioners, secretary and clerks, office rent and the like, and that the balance be apportioned among the municipalities in which the commissioner's work is done, each municipality to pay that part of the cost of the field work, which the time devoted to it bears to the whole time spent in such work."

With regard to the concentration of purchases the commission recommended the establishment of a purchasing board to consist of the Governor, the state treasurer and the state comptroller, the board to employ a purchasing agent, and that all discretion as to purchases and standardization of supplies should be vested entirely in this board. At the time of the recommendation the purchasing power was exercised generally by each commission or department or institution independently, subject only to the terms of the appropriation bill. Drafts of bills embodying these recommenrlations were submitted by the commission.

\section{PURLICATIONS}

Message of the Governor transmitting [first] report of the commission to consider best means to consolidate state agencies. To the Legislature-session of 19I3. Trenton, MacCrellish \& Quigley, state printers, I9I3. 3I p. 2 fold. charts (in envelope).

Recommendations.

Consolidation of state board of assessors and the board of equalization.

Abolition of the separate shell fish commission, and consolidation under a central bureau of game and fisheries.

Combination of the department of labor, bureau of labor statistics and employers liability commission.

${ }^{1}$ Fourth Report of the Commission upon the Reorganization and Consolidation of Different Departments of the State Government whose Functions are Interrelated (The Economy and Efficiency Commission), 1916. p. 5 . 


\section{AGENCIES OF PARTICULAR STATES, OFFICIAL}

Consolidation of the offices of comptroller of the treasury and the department of accounts.

Union of the department of inland waterways and the New Jersey canal commission.

Message of James F. Fielder, governor of New Jersey, transmitting to the Legislature the second report of the Commission upon the reorganization and consolidation of different departments of the state government whose functions are interrelated. Feb. I6, I9I4. Trenton, I9I4. 94 p. tables (part. fold.).

Contents.

Introduction.

State board of health.

Department of shell fisheries.

Department of taxation.

Department of conservation and development.

Department of commerce and navigation.

The state prison.

Department of labor.

Third report of the Economy and efficiency commission (commission upon the reorganization and consolidation of different departments of the state government whose functions are interrelated.) Likewise incorporating as a supplemental report a report of Price, Waterhouse \& co., expert chartered accountants, as sustaining the Economy and efficiency commission in a survey of specific conclusions and recommendations. Trenton, I9I5. I5 p. Contents.

Report of the Commission.

Report on proposed department of conservation and development, by Price, Waterhouse \& co.

Fourth report of the Commission upon the reorganization and consolidation of the different departments of the state government (the Efficiency and economy commission) to the Governor and Legislature of the state of New Jersey. January 4, I9I6. Trenton, 1916. 26 p. fold. chart.

Contents.

Recommendation concerning enforcement of tenement house act.

Concentration of purchases.

\section{ARTICLES}

Hanford, C. A. The New Jersey Economy and efficiency commission. (In Illinois. General assembly. Efficiency and economy committee. Report. Chicago, 1915. p. 98I-85.)

Massachusetts: Commission on Economy and Efficiency. The Massachusetts Commission on Economy and Efficiency was created by an act of the legislature approved June 6, I9I2. ${ }^{1}$ Prior to this the Governor, at his request, had been authorized by the legislature to investigate the organization

${ }^{1}$ Massachusetts, Acts, I9I2, p. 800. 


\section{EFFORTS FOR ADMINISTRATIVE REFORM}

and work of the administrative departments and services in order that he might more intelligently prepare the budget which he was directed to submit to the legislature, and for this purpose temporarily to employ public accountants, engineers and other investigators. This provision did not give the results that were expected of it, due to the fact that the work of investigation was not carried on in a sufficiently systematic and continuous manner. To correct these defects the legislature in I9I 2 repealed the act under which the Governor was acting and provided for the creation of the Commission on Economy and Efficiency which has been mentioned.

This commission was reorganized by act of June 25 , I9I 5 . By that statute it was provided that the commission should consist of three members appointed by the Governor with the consent of the Council, a chairman holding office at the pleasure of the Governor and receiving a salary of $\$ 5,000$ per annum, and two members holding office for a term of three years and receiving a salary each of $\$ 4,500$ per annum. The commission was empowered to employ expert and clerical assistance, and appropriations were made for its support.

This commission was directed:

To inquire into the laws governing the financial transactions of the Commonwalth and to study into the possibility of promoting greater economy and efficiency and utility in the transaction of the business of the Commonwealth by any changes in such laws, by the reorganization, consolidation or coördination of departments and institutions, by different methods of administration, by classification of employees, by fixing maximum and minimum salaries, by standardizing vacations, by organizing a central purchasing agency or department, by the substitution of the budget method of appropriating money or by any other means, and it shall report thereon from time to time to the Governor and Council and to the General Court, if it is in session.

The commission thus established was of a somewhat different character from the commissions similarly designated created by other states, in that, in addition to being given the general duty of investigating the organization and methods of business of the administrative services of the government, it 
was made an operating department with specific duties with reference to the preparation and submission of estimates. It thus provided that the auditor should continue to make his compilation of the estimates of the departments, but that, in addition to furnishing the Governor with a copy of such compilation, he should also furnish to the commission a copy, and that the latter body:

Shall examine the statements submitted to it by the Auditor, showing the general and special appropriations asked for by those in charge of the various departments, institutions, boards and undertakings mentioned in sections three and four, and shall report thereon to the General Court annually on or before the first Thursday in January, and at such other times as it may see fit, together with such facts, suggestions or recommendations as to any or all of the appropriations requested or the methods of raising money for the same as it may deem expedient.

It will be noted that by the foregoing the Commission or Economy and Efficiency was directed to make its recommendations direct to the legislature and not to the Governor. Furthermore, the provision of law directing that the Governor should make recommendations regarding estimates was repealed. Though the act thus made a distinct advance in providing for a budgetary organ, it made this organ an agent of the legislature rather than of the Executive, and thus was in no sense a movement towards an executive budget.

That the legislature was not of the opinion that, in making provision for this body, it had solved the budgetary problem, is evident from the fact that this body was specifically instructed by the act to investigate and report regarding the steps that would be required to put the administration of the government upon a budgetary basis.

The commission was also empowered to make investigations as to the financial administration of state services or state-aided institutions, and was required so to do when requested by the Governor, or either branch of the legislature or by the committee on finance of the Governor's Council.

The commission was given the usual powers to compel tes- 
timony and the production of papers and was required to make an annual administrative report.

On June I, I9I6, the legislature passed an act abolishing the commission and creating in its place the office of Supervisor of Administration. ${ }^{1}$ Practically all of the powers and duties of the commission were transferred to its successor, the Supervisor of Administration, but in addition he was vested with certain administrative functions which make it proper to regard his office as an organ of central administrative control rather than as a research agency. Account of that office is, therefore, reserved for the second part of this volume. ${ }^{2}$ Here we will confine ourselves to a brief characterization of the work of the commission.

The first important task of the commission was to undertake a thorough investigation into the organization, methods of operation and activities of the various services of the state.

On February 7, I9I4, the commission submitted a report of some fifty pages on the "Reorganization of Boards and Commissions Having Supervision and Control of State Institutions," in which a centralization and unification of control is advocated; and in November of the same year, a report of more than five hundred pages dealing descriptively with "The Functions, Organization and Administration of the Departments in the Executive Branch of the State Government."

The annual reports of the commission, besides giving information regarding the work of the commission in general, present the results of a large number of special investigations. In addition, the commission submitted a considerable number of special reports. The character of these reports can be seen from the appended list of the published reports of the commission.

\section{PUBLICATIONS}

Annual report of the Commission on economy and efficiency. [November 2I, I9I2, to] December 3I, I9I2. Boston, Wright and Potter Printing Co., state printers, I913. 9 p. (Public Doc. No. 96.)

${ }^{1}$ An Act to Abolish the Commission on Economy and Efficiency and the State Board of Publications and to Establish the Office of Supervisor of Administration. Approved June I, I916. Act of 1916, Ch. 296.

See p. $29 \mathrm{I} \mathrm{ff}$. 


\section{AGENCIES OF PARTICULAR STATES, OFFICIAL}

Annual report of the Commission on economy and efficiency for the year ending December 3I, I9I3. Boston, 1914. I45 p. (Public Doc. No. 96.)

Contents.

Salaries of state officials and employees.

Educational matters.

Care of public records.

Ballot law commission.

Labor.

Fisheries and game.

Forestry and moth suppression.

Business administration in county institutions.

Pending investigation and recommendations.

Annual report of the Commission on economy and efficiency for 1914. Boston, 1915. 319 p. fold. tables. (Public Doc. No. 96.) Contents.

Summary of work performed during the year.

Report on reorganization of boards and commissions having supervision and control of "state institutions.

Report on functions, organization and administration of the departments in the executive branch of the state government.

Salaries of state officials and employees.

Vacation allowances.

Appropriations and state revenue.

Conversion of state sinking fund bond into serial bonds.

Report on the expenditure and accounts of the Board of registration in dentistry.

Report on expense accounts of officials and employees in the service of the Commonwealth.

Report on bills for services and expenses of space expert employed in the State House building commission.

Report on state armory loans and on Armory commission's administration of its finances.

Report on the business administration of the state militia.

Published records of the Massachusetts militia who served in the War of $1812-14$.

Report on alleged selling methods used by the Massachusetts Commission for the blind.

Report on number of alien immigrants admitted to state institutions within three years of their entrance into the United States.

Report on administration of state normal schools.

Appendix A. Acts establishing and reorganizing the Commission on economy and efficiency.

Appendix B. List of state officials and employees whose salaries are fixed by statute, are subject to approval of Governor and Council, or are specified in appropriation acts.

Annual report of the Commission on economy and efficiency [for] 1915. Boston, 1916. 304 p. (Public Doc. No. 96.)

Contents.

Summary of work performed during the year.

Appropriations: Reports [on various House and Senate bills]. 


\section{EFFORTS FOR ADMINISTRATIVE REFORM}

Report on non-registered physicians employed at state institutions.

Report on the shoe industry at the Massachusetts reformatory.

Report on the work and administration of the Department of the State forester.

Organization, salaries and leaves of absence.

Reorganization of boards and commissions having supervision and control of state institutions. Report submitted by Commission on economy and efficiency. Feb. 7, 19I4. Boston, 1914. 63 p. fold. tab. (House. Doc. No. 2137.)

Contents.

Plan I. Centralized control under a board of five commissioners empowered to vest in one director the duties of administration.

Plan II. Supervision and control by a Board of five commissioners; to give all their time to the duties of their offices, and to be chosen with particular reference to the several different problems involved from an administrative and correctional standpoint.

[Report of Commission on economy and efficiency] Argument submitted by the chairman of the Commission to the joint committees of Ways and means and Public institutions [relative to the work of the Commission and its recommendations for reorganization of boards and commissions having supervision and control of state institutions]. April I5, I9I4. 35 p. (House. Doc. No. 2473.)

This report supplements House Doc. No. 2137.

Functions, organization and administration of the departments in the executive branch of the state government. Prepared by the Commission on economy and efficiency. November [25], 19I4. Boston, I9I4. 5I3 p. fold. chart.

Contents.

Definition of terms.

Summary of the present organization of the executive branch of the state government, with chart.

Central control and supervision of state departments.

Types of departmental organization and methods of administration.

Departments engaged in work of a similar character or having a similar object.

Detailed description of the functions, organization, etc., of each state department, board, commission and institution.

City officials and other non-state officials appointed by the Governor.

State aided institutions and organizations.

Appendix. Geographical location of state offices, institutions, armories, stations, etc.

Report on proposed conversion of state sinking fund bonds by issue of serial bonds. Submitted to the General court ... by the Commission on economy and efficiency, Jan. 15, 1915. Boston, I9I5. 24 p. (House. Doc. No. 1650.)

Documents and papers submitted by the Massachusetts Commission on economy and efficiency to the Honorable Senate and House of representatives of the commonwealth of Massachusetts in 
General court assembled. February I5, I9I5. Boston, I9I5. 64 p. (House. Doc. No. I751.)

Contents.

Report on the action taken by the Department of animal industry to extirpate the foot-and-mouth disease in Massachusetts submitted to his excellency the Governor and the Honorable Council by the Commission on economy and efficiency, Dec. 23, I9I4.

Transcript of notes taken at the hearing given by the Commission on economy and efficiency to Mr. Fred L. Walker, Commissioner of animal industry, at Room I ro, State House, Boston, on Monday, December 14, I9I4, at 2:30 P. M.

Miscellaneous letters, etc.

Laws relating to contagious diseases of domestic animals.

Report on the work and administration of the Board of commissioners on fisheries and game, submitted to Governor and Council and General court by the Commission on economy and efficiency. April 26, I9I5. Boston, I9I5. $5^{8}$ p. (House. Doc. No. 2133.)

Contents.

Letter of transmittal, with summary of recommendations.

Description of work, finances and organization.

Criticisms and recommendations.

Appendices.

Report of the Commission on economy and efficiency concerning the standardization of grades and compensation in the civil engineering service of the Commonwealth as proposed in House bill No. 349 of I9I5. January I2, I9I6. Boston, I9I6. 28 p. (House. Doc. No. I673.)

Report of the Commission on cconomy and efficiency relative to the hours of labor of public employees and to Saturday half holidays. Jan. 12, 1916. Boston, 1916. $5^{8}$ p. (House. Doc. No. 1672.)

Report of the Commission on economy and efficiency on statements submitted to it by the State auditor. Jan. 6, I9i6. 3 p. (House. Doc. No. I1.)

Report on the administration of state revenues and loans, submitted to the Governor and Council and General court by the Commission on economy and efficiency. April 29, I9I6. Boston, 1916. 102 p. (House. Doc. No. 2225.)

Special report of the Commission on economy and efficiency relative to state printing. May I, I9I6. 23 p. (House. Doc. No. 2175.)

Report on budget procedure, submitting to the Governor, Council, and General court by the Commission on economy and efficiency. May 27, I9I6. Boston, I9I6. 32 p. (House. Doc. No. 2288.)

[Report on appropriations asked for by those in charge of the various departments, institutions, boards, and undertakings for the year I9I5.] Jan. 7, 19I5. 2 p. (House. Doc. No. 53.)

- Same [for I9I6]. Jan. 6, I9I6. 3 p. (House. Doc. No. II.)

\section{ARTICLES}

Hanford, A. C. The Massachusetts commission of economy and efficiency. (In Illinois. General assembly. Efficiency and economy committee. Report. Chicago, I9I5, p. 975-8I.) 
New York: Committee of Inquiry to Investigate the Administration of the State Government. Early in I9I3 Governor Sulzer of New York, in the exercise of his general executive authority, appointed three citizens as a Committee of Inquiry to make an investigation into the expenditures of the state. On March 2 I of the same year the committee submitted a report to the Governor, analyzing the appropriations of the state for the current year as well as the estimates for the ensuing year and suggesting the reduction of certain estimates.

In its investigation of the financial administration of the various departments and commissions, information was secured as to their respective appropriations for the current year, the amounts required for the ensuing year, and a statement of any increases or decreases in the same. From these data the committee presented a report containing: (I) its findings and recommendations in regard to each separate department, with particular attention to the demands for increased appropriations, and (2) a revision of the estimates for which appropriations were requested. Also a new appropriation and supply bill for the entire state was prepared, setting forth the items recommended by the Committee of Inquiry and involving a new reduction of $\$ 772,000$ as compared with the actual appropriations of the preceding year.

The Committee of Inquiry also made an analysis of the financial methods employed by the various state agencies, in order to devise means for securing economy and efficiency in the public service. As a result of this general study of state administration, the committee found that the business methods of the state were not efficient, and that there was immediate need for a complete change in the existing system of making appropriations and in the administrative machinery for controlling and safeguarding the expenditure of such appropriations after they have been made. With this end in view, the Committee of Inquiry recommended: (I) that the fiscal year be altered so as to correspond more closely to the legislative session; (2) that general appropriations be made available only during the year for which they are made; (3) that all unexpended balances lapse at the close of each year; (4) that 


\section{AGENCIES OF PARTICULAR STATES, OFFICIAL}

it should be unlaw ful for departmental officers to incur liabilities in excess of appropriations, and that they should not be empowered to make such expenditures; and (5) that supply bills should be discontinued.

These various recommendations made by the Committee of Inquiry to the Governor were transmitted to the legislature, but nothing definite was accomplished in the way of constructive legislation for carrying the same into effect.

Finally the committee made three general recommendations: that a state board of estimates be created, composed of state officials, to have the duty of formulating appropriation bills; that provision be made for a commissioner of economy and efficiency, who should have the duty of making investigation of administrative services and recommending action to be taken to put this management upon a more efficient basis; and that the system of making appropriations be changed in certain respects.

The first two of these recommendations were accepted by the legislature. By acts passed in I9I3 provision was made for a State Board of Estimates and a Department of Economy and Efficiency, with the provision that the head of the latter should be secretary of the former. ${ }^{1}$ The work of this latter department will be considered in the following section.

PUBLICATIONS

Report of the Committee of inquiry to Governor Sulzer ... Transmitted to the Legislature March 24, I9r3. Albany, J. B. Lyon Company, printers, I9I3. 7, II9 p. fold. tables.

Contents.

Message from the Governor transmitting report.

Report.

Business methods of the state and its system of finance.

Unexpended balances.

Printing.

Stationery and office supplies.

Sinking fund.

Canal claims and board of claims.

Statement of appropriations recommended by Committee of inquiry.

Departments, commissions and bureaus of the state.

State institutions and special bills and appropriations connected therewith.

Legislation recommended.

${ }^{1}$ New York, Acts, 1913, Ch. 280 and 28 I. 


\section{EFFORTS FOR ADMINISTRATIVE REFORM}

Appendices of Hon. John T. Norton, counsel to Committee of inquiry, upon sinking funds.

An act to ... create a department of efficiency and economy, etc.

An act to establish a state board of estimate, etc.

An act to establish a state board of contract and supply, etc.

\section{ARTICLES}

Hanford, C. A. The New York Committee of inquiry and Department of efficiency and economy. (In Illinois. General assembly. Efficiency and economy committee. Report. Chicago, I9I5. p. 985-88.)

New York: Department of Efficiency and Economy. As has been pointed out in the preceding section, the legislature of New York, acting upon the recommendation of the Committee of Inquiry, passed an act providing for the creation of a Department of Efficiency and Economy, which it was intended should be a permanent feature of the administrative system of the state. ${ }^{1}$

This act provided for a Department of Efficiency and Economy at the head of which should be a "Commissioner of Efficiency and Economy." At the time it was in full operation the department consisted of the office of the commissioner, a secretarial division, an accounting division and a legal division, all of which were included under the general administration. In addition there was an advisory board, a bureau of finance and budget, a bureau of curative, charitable and penal institutions, a bureau of public works department, and a bureau of miscellaneous departments comprising a miscellaneous division, an education division and a printing division.

The duties of the department were stated in the following terms :

"The Commissioner of efficiency and economy shall make a careful and thorough study of each office, institution and department maintained by the state and shall from time to time make recommendations to the governor and to the officer, board or commission in charge of said office, institution or department touching the efficiency and economy of the work, business and service therein. He is hereby empowered, and it shall be his duty to examine the accounts, and the methods

\footnotetext{
${ }^{1}$ New York, Acts, I9I3, Ch. 280.
} 
of business, accounting and administration of the several offices, institutions and departments supported by the state, for the conduct and maintenance of which any appropriation of moneys is made by law."

The act further provided that the commissioner should have power to compel testimony and production of papers, that all officers of administrative services and state institutions should annually submit to him, on forms prescribed by him, detailed statements of their estimates for appropriations and that the commissioner should examine said statement and make such recommendations thereon as, in his opinion, would contribute to promote efficiency and economy in the conduct of the business of the state.

The Department of Efficiency and Enonomy upon its organization as a department devoted its first attention to the matter of state appropriations and expenditures, and on March I6, I9I4, the commissioner submitted a comprehensive budget report of I035 pages to the Governor, setting forth his recommendations in regard to the financial needs of the state for the fiscal year beginning October I, I9I4. The items of appropriation recommended in this report were determined after a careful examination of the requests for appropriations as filed by the various department officers, and every item was presented in comparison with the amounts appropriated the previous year, thus bringing into relief each new position in the state service, every increase in salary and every proposed addition to miscellaneous expense. With these data as a basis, the commissioner of efficiency and economy prepared a completely segregated form of appropriation bill or budget, presenting all positions under their proper departmental titles, and subdividing every large item of miscellaneous expense into smaller units so as to prevent the concealment of unnecessary positions and expense accounts under the heading of office expense and other deceptive titles. Nearly every estimate submitted by the heads of departments was revised and materially decreased, and the amounts recommended by the commissioner of efficiency and economy were set forth in itemized form and in parallel columns alongside of the appropriation requests submitted by the departmental heads in the usual 
unitemized form, while the whole report was supplemented by explanatory notes from the departments concerned and from the commissioner of efficiency and economy. The amount of appropriation recommended by the commissioner was about one-seventh less than that recommended by the departmental heads.

This report was transmitted to the legislature January $2 \mathrm{I}$, I9I5. It, however, received no serious attention at the hands of that body and the annual appropriation act was passed in the usual form.

Under date of January I, I9I5, the department in cooperation with the New York Bureau of Municipal Research published a detailed report of 768 pages on the organization and functions of the government of the state of New York, prepared for the use of the constitutional convention held in I9I5. This report was descriptive and was accompanied by a large number of charts of organization and other data. It was also published as one of the series of reports of the New York State Constitutional Convention Commission.

Under date of January 2I, I9I5, the commissioner of efficiency and economy transmitted a report of 445 pages giving the result of an investigation of the cost of providing text books for the schools of the state, including both those supported by the state and those supported by the several cities, towns, villages and school districts.

An annual report of I,OI9 pages submitted by the commissioner gave the results of an investigation of state hospitals for the insane, state prisons and state reformatory and correctional institutions and recommendations relative to the improvement of the efficiency of their administration.

Under date of February I, I9I5, the department transmitted an annual report of 385 pages relating to the construction and maintenance of public highways and the administration of the State Highway Department, with recommendations as to statutory amendments. The investigations of the department and the numerous suggestions that were transmitted from time to time provided the commissioner of highways with information about organization and methods which resulted in better discipline and better quality of work.

Notwithstanding the activity of this department, its work 
did not seem to meet with the approval of the legislature and it was abolished in $1915 .^{1}$ The reason for this action was undoubtedly in part due to political considerations.

\section{PUBLICATIONS}

State budget report by Department of efficiency and economy. Appropriations recommended for fiscal year beginning October I, 19I4. Explanatory notes by heads of departments, critical notes and analytical tables by Department of efficiency and economy. Transmitted to the Governor, March I6, I9I4. [Albany, 19I4.] VII, $262 \mathrm{p}$.

Budget report of the New York Department of efficiency and economy concerning appropriations requested by the state departments, institutions, boards and commissions. Transmitted to the Legislature January 21, 1915. Albany, 1915. XXXVI, 995 p. incl. tables. [Annual report, I9I4, v. I.]

Government of the state of New York. A description of its organization and functions. Prepared for the New York State constitutional convention commission by the New York State department of efficiency and economy and New York Bureau of municipal research. January I, 1915. Albany, 1915. XXXII, 768 p. diagrs. (part. fold.) [Annual report, I9r4, v. 2.]

Report of investigation of the cost of providing free text-books in the public schools of the state of New York, by the State department of efficiency and economy. 1914. Albany, 1915. $445 \mathrm{p}$. incl. map. [Annual report, 1914, v. 3.]

Partial Contents.

Bibliography of the school text-book question.

Digest of the text-book laws of the states of the Union.

Annual report of the New York Department of efficiency and economy concerning investigations of accounting, administration and construction of state hospitals for the insane, state prisons and state reformatory and correctional institutions. Transmitted to the legislature February I, 1915. Albany, 1915. XXII, 993 p. plates, fold. diagrs. [Annual report, I914, v. 4.]

\section{Contents.}

Introduction.

Review of examinations of accounting methods in state hospitals for the insane, by Wood Drake Loudoun. p. I-28.

Detailed reports of investigations of state hospitals for the insane, by the staff of the Department. p. 29-294.

Organization and administration of state hospitals for the insane, by M. E. McCalmont. p. 40I-612.

Problems of construction of buildings for the state hospitals for the insane, by Albert L. Brockway. p. 613-665.

Examination of state prisons and correctional institutions, by Charles H. Jackson. p. 697-682.

State charitable institutions. p. 983-993.

Annual report of the New York Department of efficiency and economy concerning matters relating to the construction and main-

${ }^{1}$ New York, Acts, I9i5, Ch. 17. 


\section{EFFORTS FOR ADMINISTRATIVE REFORM}

tenance of public highways. Transmitted to the Legislature February I, I9I5. Albany, I9I5. XVIII, 365 p. plates, fold. diagrs. [Annual report, I9I4, v. 5.]

Contents.

Pt. I. Report of Advisory board of New York Department of efficiency and economy by Arthur $\mathrm{H}$. Blanchard.

Apportionment of state funds for construction of highways.

Financing the maintenance of the public highways.

Organization of the New York State highway department.

Preliminary investigations to determine suitable types of highways.

Specifications under which New York highways have been constructed.

Complete and accurate surveys required for correct designing.

Comprehensive advertisements necessary to secure competition in bidding.

Defective contracts principal cause of poor construction.

Maintenance contracts inadequate in regard to work and materials.

Reorganization of Bureau of tests necessary to secure efficiency.

Revision of traffic regulations to protect state highways.

Valuable data for highway commission in other state departments.

Protection of sources of trap rock supply.

Pt. II. Review of the work of the Department of efficiency and economy in relation to public highways, by the Commissioner of efficiency and economy.

The constitution and government of the state of New York: an appraisal. Transmitted to the New York state constitutional convention by the New York state constitutional convention commission. Prepared ... by the Bureau of municipal research and the New York state department of efficiency and economy. [Albany] Bureau of municipal research, I9I5. XII, 250 p. incl. diagrs.

Contents.

Introduction and summary.

Standards for the appraisement of the present constitution and government.

The electorate.

The official personnel.

The structure of government and the powers, duties and limitations of officers.

Organization and procedure of the Legislature.

Constitutional provisions defining the relations of Legislature and Executive.

The independent auditor.

The governor and the administration.

Organization for the administration of the states' proprietary and other general functions.

Organization for the administration of military functions of the state government. 


\section{AGENCIES OF PARTICULAR STATES, OFFICIAL}

Organization for the administration of public service functions. The content and form of the Constitution.

\section{ARTICLES}

Hanford, A. C. The New York Committee of inquiry and Department of efficiency and economy. (In Illinois. General assembly. Efficiency and economy committee. Report. Chicago, I9I5. p. 985-88.)

\section{Pennsylvania: Economy and Efficiency Commission. By} a joint resolution, approved July 25, I9I3, the legislature of Pennsylvania provided for the creation of a body to be known as the Economy and Efficiency Commission which should have the duty "to investigate the number, character of duties and compensation of all persons in the employ of the State; and to ascertain and recommend what changes, if any, may be necessary to secure greater uniformity, economy and efficiency in the work of the various departments, branches, bureaus, and commissions of the government." The reso-lution provided that the commission should be composed of: three persons "well versed in business and governmental affairs and in systems of economy and efficiency in administration," to be appointed by the Governor and to receive a compensation of $\$ 3,000$; and that this commission should make its report not later than November I, I9I4, when it should become functus officio. An appropriation of $\$ 25,000$ was made to defray the expenses of the commission, which amount, however, was reduced by the Governor to $\$ 10,000$.

This commission made its report under date of December 24, I9I4. It is devoted to an enumeration and description of the administrative services and institutions of the state with recommendations of action that should be taken in reference to each to make the organization and work more efficient.

By a concurrent resolution, approved June I7, I9I5, provision was made for the appointment of a new Economy and Efficiency Commission, to consist of the Governor, the auditor general and the attorney general, which should continue the work of the old commission besides undertaking new lines of work which were specified in the resolution. Provision was made that the expenses of this commission should be met from moneys carried in the general appropriation act. 


\section{EFFORTS FOR ADMINISTRATIVE REFORM}

This commission made its report on March 28, I9I7, in the form of a report by its solicitor, which covers much the same ground as the report of its predecessor though devoting more attention to general problems of administration, such as the introduction of a budget system, the equalization of salaries, etc.

\section{PUBLICATIONS}

Report of the Economy and efficiency commission of the commonwealth of Pennsylvania. Harrisburg, W. S. Ray, state printer, I9I5. VI, 64 p.

Contents.

Report.

Appendix: Tables giving reference to the Acts of Assembly creating and relating to each department; name, compensation received and position held by each officer and employee; act regulating each position and indicating method of its creation, by statute, appropriation or contingent fund.

Report of Harry S. McDevitt, the Solicitor of the Economy and efficiency commission of the commonwealth of Pennsylvania [together with conclusions and recommendations]. March 28, I9I7. Harrisburg, I9I7. $72 \mathrm{p}$

\section{ARTICLES}

Hanford, A. C. The Pennsylvania Economy and efficiency commission. (In Illinois. General Assembly. Efficiency and economy committee. Report. Chicago, I9I5. p. 988-990.)

Illinois: Efficiency and Economy Committee. Easily the most important commission on economy and efficiency that has been established by any state, whether judged from the standpoint of the comprehensive and scientific character of its work, or from that of actual results accomplished, is the body known as the Illinois Efficiency and Economy Committee. In his inaugural address, in I9I3, Governor Dunne recommended "the appointment of a joint committee of both houses of the legislature to examine into the condition of the public institutions of the state and to confer with the Board of Administration to ascertain if it is not possible to reduce the expenditures of the same without impairing the efficiency of these institutions." In pursuance of this recommendation the legislature in the same year passed a joint resolution providing for the creation of such a body, ${ }^{1}$ and subsequently appropriated the sum of $\$ 40,000$ for its support.

${ }^{1}$ Senate Joint Resolution No. 22, 48th General Assembly, I9I3. 


\section{AGENCIES OF PARTICULAR STATES, OFFICIAL}

This resolution provided for the constitution of a joint committee composed of four senators and four representatives which should have full power and authority:

To investigate all departments of the state government including all boards, bureaus and commissions which have been created by the General Assembly, such investigations to be made with a view of securing a more perfect system of accounting, combining and centralizing the duties of the various departments, abolishing such as are useless and securing for the state of Illinois such reorganization that will promote greater efficiency and greater economy in her various branches of government.

This committee, as its most important work, made an exceedingly thorough and detailed study of the entire administrative machinery of the government, the results of which were published in a report submitted in I9I 5. This report is an exceptionally able document. In addition to containing the report proper of the committee it includes twelve special reports on particular topics prepared by specialists appointed for the purpose and performing their work under the general direction of Mr. John A. Fairlie, Professor of Political Science at the University of Illinois. Although we have not attempted in the present volume to summarize the conclusions reached by the other investigating bodies considered, the present report is such an exceptionally able document, presents such a convincing indictment of existing administrative conditions, not only in Illinois but in almost all of our states, and points out so clearly the steps that should be taken to relieve these conditions, that we feel justified in making an exception in its case. The findings and recommendations of the committee, as summarized in its report, were as follows:

There is unnecessary duplication of positions and salaries; not only in the chief officers of each separate bureau or board, but still more in their staffs of clerks and employees. But this is the smallest part of the loss. The work that is undertaken is not well done; and costs much more for the results obtained than with a more efficient organization. Supplies in many cases are purchased in small quantities for each office or institution, which could be secured at lower prices if purchased in 
larger quantities on contracts based on competitive bids, as is done by the Board of Administration for the charitable institutions. The absence of definite correlation and coöperation between the most closely related offices, necessarily leads to loss and inefficient work. The only supervision provided by law over most of the executive offices, boards and commissions, burdens the Governor with a mass of unnecessary detail which no single individual can effectively handle, and at the same time does not afford him either the time or the facilities for the proper determination of the more important questions of administrative and legislative policy. The present arrangements also fail to provide the General Assembly with adequate information or advice to enable it to perform its work wisely, either in making appropriations or in enacting substantive legislation. And while reports are made and published, they are so numerous and poorly organized that the general public fails to receive satisfactory information of the work that is done, and has no satisfactory means for fixing responsibility, or of discriminating between those officials who perform their work well and those who perform it poorly or not at all.

Lack of Correlation. Under the existing arrangements inefficiency and waste necessarily arise from the lack of correlation and coöperation in the work of different offices and institutions which are carrying out similar or closely related functions. There are separate boards for each of the State penitentiaries and reformatory and for each of the State normal schools. There are half a dozen boards dealing with agricultural interests; and about a score of separate labor agencies, including four boards dealing with mining problems and eight free employment offices, each substantially independent of each other. State finance administration is distributed between a number of elective and appointive officials and boards without concentrated responsibility. The supervision of corporations, and of banks, insurance companies and public utilities is exercised by a series of distinct departments. State control of public health is divided between various boards with no effective means of coördination. Nor is there any official authority for harmonizing the work of the numerous educational agencies.

The division of the public service in some fields has even affected the authority of the State officials, provided by the constitution, where in. some cases unrelated functions are placed under the same official. The title of the Auditor of 
Public Accounts indicates that he should control the auditing of all public accounts in the State; but his authority in this field is limited; on the other hand, he has supervision over banks and building and loan associations, a function quite distinct from the audit of public accounts. So, too, the Attorney General should be the chief legal officer for all State offices and departments; but special counsel and attorneys have been provided for various departments, independent of the Attorney General and not subject to his control; while this officer has been given supervision over inheritance tax administration, which should be primarily a financial rather than a legal matter.

Scattered Offices. The lack of correlation between different State offices is further indicated and emphasized by the physical location of their offices. Thirty State officials and commissions have offices in Chicago, at a cost for rent and other expenses of $\$ 72,000$ a year. These offices are scattered in different buildings, even in the case of departments whose functions are most closely related to each other. The present arrangements cause an unnecessary expenditure of funds for offices, reduce the efficiency of the State service in their dealings with each other, and add greatly to the inconvenience of the general public in transacting business with these offices.

No Standards of Compensation. Under existing legislation the compensation of State officers lacks any approach to uniformity on the basis of work done. Not only are there boards and officials who receive no salary, others paid on a per diem basis, and still others paid a fixed salary; but within each of these classes there is no attempt to adjust the compensation to the time given to the public service or to the duties performed. The State Food Commissioner and the Chief Inspector of Private Employment Agencies each receive $\$ 3,600$ a year; while the more important offices of Secretary of the State Board of Health and Chief Factory Inspector receive only $\$ 3,500$ and $\$ 3,000$. The Commissioners of Labor each receive $\$$ I 50 a year; while the members of the Board of Arbitration each receive $\$ 1,500$ a year, and the members of the State Board of Pardons $\$ 3,500$ a year. Inspectors in different departments doing a similar type of work receive salaries ranging from $\$ \mathrm{I}, 200$ in one department to $\$ 1,800$ in another. The same variations in compensation for similar work exist for subordinate positions, where the salaries are specified in the appropriation acts. 
Overlapping Functions. Even where there is no direct duplication of work, the present laws frequently give powers to several departments under which each employs agents for purposes which could be more efficiently and economically performed by one agent at the same time. Thus the inspectors of the State Board of Health, the State Food Commissioner and the Chief Factory Inspector may each visit the same place for different purposes and perhaps give conflicting orders; while a single thorough inspection for all of these offices would be more effective and less expensive.

Irregularity of Reports. One source of confusion in the operation of the numerous State offices, boards and commissions is the complete absence of uniformity or regularity as to their reports. Most officers are required to report to the Governor; but in several cases reports are made directly to the General Assembly, and in some cases no authority is specified. There seems to be no rule followed in requiring reports to be made annually or biennially or at other intervals. Reports are required to be made by some authority in every month in the year except April; and cover widely varying periods of time.

The separate publication of reports for each minor office and the lack of central control over the printing of such reports add much to the expense of printing, which now amounts to over $\$ 500,000$ for the biennium. A large proportion of this could be saved by a more concentrated organization and control over the official reports.

Ineffective Supervision. As a result of the absence of any systematic organization of related services, there is no effective supervision and control over the various State offices, boards and commissions. It is true that the greater number of these are under the nominal supervision of the Governor, through his power of appointment and removal. But the very number of separate offices makes impossible the exercise of any adequate control. To a very large extent each authority is left to determine its own action; conflict of authority between two or more offices is often possible; and if harmony and coöperation is secured it is by voluntary compromise rather than by the advice or decision of a superior authority. Under the present arrangements too many independent authorities have power to make expenditures subject to no effective centralized control or responsibility. This situation necessarily leads to waste and extravagance.

At the same time, the number of matters necessarily I 38 
brought to the attention of the Governor-owing to the absence of intermediate supervising officers-has burdened him with such a mass of details that he has been unable to exercise adequate supervision over such matters, while the very volume of such business brought to his attention takes time from more important questions of general policy.

Moreover, a number of the important departments and services are not even under this limited supervision of the Governor. This is true of the officers provided for by the constitution; and also of a number of boards chosen by election or by other methods, as the State Board of Equalization, the Trustees of the University of Illinois, and the State Board of Agriculture. In the case of the constitutional officers this lack of control extends not only to their primary functions, but also to other unrelated powers and duties imposed on them by statute.

No Budget System. One of the most serious defects arising from the lack of correlation and effective supervision over the subordinate authorities is the absence of any satisfactory budget of estimates as a basis for appropriations. The need for improvement in this respect was indicated in the act of the last General Assembly creating the Legislative Reference Bureau, which imposed on that Bureau the duty of compiling estimates of appropriations. Under the procedure which has hitherto been followed, appropriations have been based in the main upon estimates and requests made by the head of each office, bureau or board, most of which officials have not been charged with a sufficient degree of responsibility to make them careful and sparing in their requests. The General Assembly has been compelled to act upon these requests without sufficient time, means or opportunity for adequate investigation. The result has been that unnecessary appropriations have been made in some cases while in other cases needed funds for important public services have not been provided.

The State Constitution, in Article V, paragraph 7, provides that the Governor at the commencement of each regular session of the General Assembly shall "present estimates of the amount of money required to be raised by taxation for all purposes." So far as your Committee is aware, no Governor has heretofore ever complied with this important constitutional duty. The failure to do so has undoubtedly been due in the main to the fact that the executive authorities as organized have not afforded the Governor the facilities needed 


\section{EFFORTS FOR ADMINISTRATIVE REFORM}

to perform this duty. Just as the number of minor offices and boards under his nominal supervision prevents any effective control over their action; so too it prevents any adequate examination of their requests for appropriations on which the Governor can base his recommendations.

The compilation of estimates for appropriations requested to be prepared by the Legislative Reference Bureau is a step in the right direction; but this can hardly be considered an entirely satisfactory budget system.

In the opinion of the Committee, the constitutional provision referred to above contemplates that the Governor shall present to the General Assembly a detailed budget of appropriations recommended by him for the ensuing biennium, together with an estimate of the revenues of the State from sources other than direct taxation during the biennium, and a statement as to the amount to be met by taxation. The careful preparation of such a budget would be a potent factor in securing economy and efficiency throughout the executive departments. But to make this possible requires not only new methods of preparing and analyzing estimates, but also extensive reorganization and consolidation of the executive departments, so that the estimates from each group of related services may be based on adequate consideration by competent officials. A new Governor will not be able to present such a budget at the beginning of the regular session of the General Assembly, but he could do so probably by March I.

Imperfect Accounts. As a result largely of the absence of a proper budgetary system, the accounts of most of the various State authorities are entirely inadequate. The accounts kept by the Auditor of Public Accounts cover all that is required by law, and appear to be carefully administered ; but they are limited to records of cash transactions and to keeping disbursements within the authorized appropriations. There is no record for the State as a whole or for most of the State offices of estimated revenues or outstanding obligations, and no attempt at preparing a balance sheet of assets and liabilities. Accounts and financial statements even for similar institutions and offices (such as the penitentiaries) are so radically different that comparison and deductions are impossible. Without an adequate system of accounting along similar lines there can be no effective control over appropriations or expenditures.

Inadequate Advice on Legislation. With the existing lack of efficient executive organization, both the Governor and the 


\section{AGENCIES OF PARTICULAR STATES, OFFICIAL}

General Assembly fail to receive proper information and advice as to needed legislation. The constitution provides that the Governor shall recommend to the General Assembly such measures as he shall deem expedient. But no machinery has been provided by which the recommendations and proposals for legislation from the numerous lists of officers, boards and commissions can be carefully weighed and sifted by officials charged with responsibility over a large field of administration. Conflicting measures are often proposed by different State authorities; and many proposals are presented from outside sources both on subjects within and without the jurisdiction of existing executive officials. As a result there is no harmonious legislative policy even formulated; and the measures enacted not only lack coherence, but at times acts are passed at the same session which contain directly contradictory provisions. There is clear need for an executive organization which will make possible a well-defined administrative program of legislation.

Another result of the present methods of legislation has been the creation of many new and independent authorities, at an increased expense to the State, where in many cases the work might have been more efficiently and economically organized in connection with some existing agency. For example, a Fish Commission was established in 1879, and a separate office of Game Commissioner in 1889. In I9I3, these two authorities were consolidated under the Game and Fish Conservation Commission; and the appropriations for this body were $\$ 50,000$ less than those made two years before for the two separate authorities.

Irresponsible Government. Finally under the present arrangements while the general public is deluged with printed reports, it fails to receive reliable information in digestible form as to the conduct of the State administration, and is unable to locate definite responsibility for negligence or misconduct in public business. Public opinion usually considers the Governor responsible for the conduct of the State government; but with the lack of effective executive control over the subordinate officials this opinion is not fully justified. At the same time, the popular conception of the Governor's responsibility, in the opinion of this Committee, is based on a sound and just principle; and the machinery of state administration should be so organized as to enable this conception to be adequately realized. 


\section{EFFORTS FOR ADMINISTRATIVE REFORM}

To correct these conditions the committee made a large number of very important recommendations. Among these chief mention should be made that the entire administrative system of the state be reorganized so as to bring into existence an integrated system of administration corresponding to that of the national government, that provision be made for a strong organ of central financial and administrative control and that the state definitely adopt a scientific budget system. These far-reaching recommendations were for the most part accepted and acted upon by the next General Assembly. By an act approved March 7, I9I7, entitled "An Act in Relation to the Civil Administration of the State Government," provision was made for a thorough reorganization of the administrative branch of the government along the lines recommended by the committee and the adoption of many of the other recommendations of that body. Specific provision was also made for the adoption of a budgetary system and a strong budgetary organ was created for its administration, under the name of the Department of Finance. As this body is decidedly an organ of central administrative control and not merely a research agency, it has been treated under the part of this volume devoted to such organs. ${ }^{1}$

\section{PUBLICATIONS}

Preliminary report of the Efficiency and economy committee ... [Chicago, I9I4.] I5 p.

Report of the Efficiency and economy committee created under the authority of the forty-eighth General assembly, state, Illinois ... [December I, I9I4.] [Chicago, The Windermere press, I9I 4.780 p. 2 fold. diagrs.

Report of the Economy and efficiency committee ... [with appendices]. [Chicago, The Windermere press], I9I5. I05I p. 2 fold. diagrs.

Partial Contents.

Present organization of state government.

Defects of the present arrangement.

Tendencies toward concentration.

Finance administration.

Charitable and correctional institutions.

Educational agencies.

Administration of labor laws.

Agricultural agencies.

Public health administration.

Public works, parks and buildings.

${ }^{1}$ See p. $296 \mathrm{ff}$. 


\section{AGENCIES OF PARTICULAR STATES, OFFICIAL}

State supervision of corporations.

Appendix [No. I]. A report on revenue and finance administrảtion, by John A. Fairlie, p. 83-183.

Revenue administration in Illinois.

Finance administration in other states and counties.

State contracts, printing and supplies. (Includes section on public printing in other states.)

Appendix [No. 2]. A report on the accounts of the state of Illinois, by George E. Frazer, p. 185-248.

Appendix [No. 3]. A report on accounting administration for correctional institutions, by Spurgeon Bell, p. 249-339.

Appendix [No. 4]. A report on charitable and correctional institutions, by James W. Garner, p. 34I-402. (Includes section on charitable and penal administration in other states and countries.)

Appendix [No. 5]. A report on educational administration, by John M. Mathews, p. 403-485.

Educational administration in Illinois.

Educational administration in other states and countrics.

State library administration.

Scientific surveys.

Examining boards.

Appendix [No. 6]. A report on the administration of labor and mining legislation, by W. F. Dodd, p. 487-59o. (Includes section on recent legislation in other states.)

Appendix [No. 7]. A report on public administration in relation to agriculture and allied interests, by James W. Garner, p. 59I-64I. (Includes section on agricultural administration in other states and countries.)

Appendix [No. 8]. A report on public health administration, by John M. Mathews, p. 643-696. (Includes sections on relation between state and local authorities, and on state health administration in New York and Wisconsin.)

Appendix [No. 9]. A report on supervision of corporations and related business, by Maurice H. Robinson, p. 697-752. (Includes section on corporation commissions in other states.)

Appendix [No. Io]. A report on state administration of public works, parks and buildings, by C. O. Gardner, p. 753865.

Highways.

Water resources.

Fish and game conservation commission.

State control of natural resources.

State parks.

Public buildings and monuments.

Appendix [No. II]. A report on the military department of the state of Illinois, by Quincy Wright, p. 867-906.

Appendix [No. I2]. A report on civil service laws, by A. C. Hanford, p. 907-938. (Includes section on civil service laws of the United States and other states.)

Appendix [No. 13]. A report on the Secretary of state and law officers, p.939-970. 


\section{EFFORTS FOR ADMINISTRATIVE REFORM}

Appendix [No. 14]. A report on economy and efficiency commissions in other states, by A. C. Hanford, p. 97 I-998. (Relates to commissions of Massachusetts, New Jersey, New York, Pennsylvania, Minnesota, and Iowa.)

Appendix [No. 15]. A report on fire insurance rates in Illinois, by Maurice H. Robinson, p. 999-1028.

Appendix [No. 16]. Comparative statement of Appropriations, made by the General assembly, state of Illinois, compiled by Thomas P. Waters, p. I029-I05I. Charts.

State executive organization in Illinois, p. I8.

Proposed state executive organization in Illinois, p. 30.

Minnesota: Efficiency and Economy Commission. In I9I3 the Governor of Minnesota appointed a commission of thirty men, so selected as to represent all parts of the state and the different political and industrial interests, to make a study and report of the changes that should be made in the administrative system of the state with a view to making such system more efficient. The commission had no appropriation from the state. Its members served without compensation and paid all of their traveling expenses. The funds necessary to meet general expenses were raised by private subscription.

This commission made two very able reports: one, a preliminary report submitted May 25, I9I4; and the other, a final report submitted in November of the same year. The recommendations of the commission centered around three fundamental reforms: (I) the thorough reorganization of the civil administration so as to provide for the establishment of a relatively few departments in substitution for the existing multiplicity of separate agencies; (2) the adoption of a scientific budget system; and (3) the definite establishment of a merit system to cover all appointments and promotions in the executive branch of the government.

Regarding the first point, the commission in its preliminary report said:

The worst faults in the present organization of the state government - the same is true of practically every state in the Union-are lack of unity and lack of responsibility. The government is incoherent. There are a multitude of disconnected, unaffiliated departments and bureaus, over which neither the governor nor the legislature nor the people have effective control. For want of coördination there is duplica- 
tion of work and an unnecessary number of employees. The Commission's plan will assure coöperation between related offices, fix "responsibility, and centralize control. Related bureaus will be grouped under a few executive departments. Each department will be headed by a single director. The directors, with two exceptions, will be appointed by the governor with the consent of the senate. The governor, the direct representative of the people, will thus be responsible for the entire administration. Instead of fifty or sixty independent governments, there will be one state administration.

Regarding the second, the report said:

The budget system means the substitution of method for what is little better than madness. It means careful consideration of the expenditures as a whole. It means study of the relative needs instead of guesswork. This consideration will begin with the executive, acting as a unit. The governor will submit to the legislature complete estimates. The legislature will no longer be assailed by the clamor of individual and even subordinate officers. It will be in a position to consider the state's expenditures as one unit made up of related parts. Haphazard extravagance will give place to systematic consideration of appropriations.

Regarding the third, the report presents the well-known arguments against the widely prevalent spoils system, and the advantages of a system under which employees have a permanency of tenure dependent only upon faithful discharge of duties, and appointments and promotions are made for merit alone. It especially brings out the necessity for a merit system under a régime of centralized responsibility such as was proposed by the commission in order to provide protection against a possible abuse of power by the Governor and the heads of the departments.

The final report has the especial value in that it contains the draft of a civil administrative code by which the reforms recommended might be put into effect.

\section{PUBLICATIONS}

Preliminary report of the Efficiency and economy commission; a plan for reorganizing the executive branch of the state government in Minnesota. The merit system in civil service, the budget sys- 
tem in appropriations. Submitted to the Governor of Minnesota, A. O. Eberhart, May 25, I9I4. St. Paul, I9I4. 30 p.

Final report of the Efficiency and economy commission: a proposed bill for reorganizing the civil administration of the state of Minnesota, the merit system in civil service, the budget system in appropriations, with prefatory statement, annotations, and explanatory notes. November, I9I4. St. Paul [I9I4] VII, 89 p. diagrs.

\section{ARTICLES}

Hanford, A. C. The Minnesota Economy and efficiency commission. (In Illinois. General assembly. Efficiency and economy committee. Report. Chicago, I9I5. p. 990-93.)

Minnesota: Commission on Reorganization of Civil Administration. The reports of the Efficiency and Economy Commission submitted in I9I4 made such a convincing showing of the defects in the existing administrative system of the state that the legislature, by resolution approved April 2I, I9I5, provided for the creation of a commission "for the purpose of investigating the advisability of making changes in the civil administration of the state, and for the further purpose of promoting more efficiency and economy in the various activities of the state." The resolution provided that the commission should be composed of eleven members: three to be appointed by the Governor, four by the Lieutenant Governor, and four by the Speaker of the House; and that it should make its report not later than November I5, I9r6.

The report of the commission was in fact submitted at a later date, and was transmitted to the legislature by the Governor as an appendix to his inaugural message in 1917. The report was a very brief one. In the main it contented itself with an indorsement of the recommendations of the Efficiency and Economy Commission, though it modifies and adds to these recommendations in certain respects. Probably its most important recommendation was that the legislature provide for the holding of a constitutional convention to the end that changes might be made in the existing constitution that would provide for or make possible a thorough reorganization of the administrative branch of the government. On this point the report reads:

It is further proposed and recommended that the coming session of the Legislature provide by law, as required by the I46 
constitution, for the holding of a constitutional convention. We in our work constantly have found that systematic revision of the departments of state on strictly business principles cannot well be done under the present constitution, and in order to accomplish a complete revision and coördination, it is absolutely essential that the constitution be changed. When the present constitution was adopted the activities of the state were limited. Since its adoption the state has increased its activities more than four-fold and it seems to us to be highly necessary that a complete revision of the constitution be made and this we believe best can be accomplished through a constitutional convention.

\section{PUBLICATIONS}

Report of Commission on reorganization of civil administration, appointed by the Governor, Lieutenant Governor and Speaker of the House. [Nov. 15, I916?] (In Minnesota. Governor. Inaugural message of Gov. J. A. A. Burnquist to the Legislature, I0I7. p. 21-27.)

The report, containing specific recommendations, was published as a supplement to the Governor's message.

lowa: Joint Committee on Retrenchment and Reform. On February 6, I9I3, the legislature of Iowa, by joint resolution, provided for the creation of a Joint Committee on Retrenchment and Reform, to be composed of the chairmen of the committees on ways and means, judiciary and appropriations of the two houses, to investigate the government of the state with a view to the introduction of reform that would bring about a more economical and efficient administration of public affairs. This committee employed the accounting firm of Quail, Parker \& Co. to assist it in its work. Later, by act of March I7, I9I3, the committee was specifically empowered to employ "expert accountants and efficiency engineers" and to "institute such changes in the administration of public affairs as will promote the efficiency and economical administration of the affairs of the state in its various departments." Under this latter authorization the firm of Quail, Parker \& Co. was employed to make further and more extensive investigations for the committee.

This firm submitted its final report on December 21, I9I3. Unfortunately this report has never been printed. It consists 


\section{EFFORTS FOR ADMINISTRATIVE REFORM}

of a closely typewritten manuscript of 84I pages. Previous reports had been submitted on the Department of Agriculture, March 25, I9I3, and on the heating plant, May 21, I9I3.

On November 12, I9I4, the committee made a brief preliminary report and announced that a fuller report would be submitted later. It does not appear, however, that this was ever done.

The work of this committee and its recommendations as well as those of the expert accountants are excellently summarized by Professor Frank E. Horack in his "Reorganization of State Government in Iowa," which appears as a chapter in Iowa Applied History Series, Vol. II. The more important recommendations were for: the introduction of a scientific budget system; the reorganization of the executive branch of the government; the creation of the office of state purchasing agent; provision for an official known as chief accountant; and the establishment of a civil service commission or bureau to administer a merit system in respect to the appointment of all administrative employees.

\section{PUBLICATIONS}

Recommendations of the Committee on retrenchment and reform of the thirty-fifth General assembly to the members of the thirtysixth General assembly and the general public. [Nov. I2, I9I4.] Des Moines, R. Henderson, state printer, I9I4. I6 p.

This "preliminary report" was published also in the Des Moines Register and Leader, Nov. I6, I9I4.

Contents.

Departments of the state's business.

Department of social progress.

Department of industries.

Budget.

Department of public safety.

Printing and binding.

Legislative.

Automobiles.

Purchasing agent.

Report [and resolution on the Department of agriculture and state fairs]. (In Iowa. Journal of the Senate, April 4, I9I3, p. I646-48.)

The interim report of Quail, Parker and company, chartered accountants and efficiency engineers, on the investigation of the Department of Agriculture is appended to the report. See p. I649-67. 


\section{ARTICLES}

Hanford, A. C. The Iowa Committee on retrenchment and reform. (In Illinois. General assembly. Efficiency and economy committee. Report. Chicago, r9I5. p. 993-97.)

Horack, Frank E. Reorganization of state government in Iowa. Iowa City, Ia., state historical society of Iowa, I9I4. 88 p. (Iowa applied history series, ed. by B. F. Shambaugh. [Vol. II, No. 2.])

Connecticut: State Commission on the Consolidation of State Commissions and the Reorganization of the Public Health Laws. On February 9, I9I5, Connecticut passed an act providing for the appointment by the Governor of a commission of nine members, a majority of whom should be members of the General Assembly or of existing state or county commissions, which was directed on or before April I, of the same year, to submit to the General Assembly a report with recommendations relative to:

The reorganization and consolidation of the various state and county boards and commissions with a view to greater economy and efficiency; the revision of the public health laws with the purpose of fixing more definitely the responsibility of officials, and of eliminating waste and duplication of authority and of preventive laws, with the purpose of ascertaining whether the constructive work of medicine and science may not be more efficient than is possible under present law.

This commission was duly constituted by the Governor, held numerous hearings at which officials of the several administrative services of the state were heard and submitted a report of something over a hundred pages giving the results of its findings and the recommendations for action. These recommendations called for the consolidation or reorganization of various services. In most all cases drafts of bills were submitted to carry out their recommendations.

As a result of the commission's report an act was passed establishing a State Department of Labor and Factory Inspection, and legislative action on the other recommendations is being considered.

\section{PUBLICATIONS}

Report of a commission to investigate the advisability of consolidating certain state boards and commissions and to investigate the 


\section{EFFORTS FOR ADMINISTRATIVE REFORM}

public health laws ... Hartford, Pub. by the state, I9I5. I08 p. fold. tab.

Contents.

Agricultural boards and commissions.

Industrial boards and commissions.

Workmen's compensation commission.

State boards of examiners.

Department of public health and the public health laws.

State tuberculosis commission.

State board of charities.

State board of fisheries and game.

State police.

Shell-fish commissioners.

Appendix: Exhibits.

Kansas: Efficiency and Economy Committee. By a joint resolution of March 20, I9I5, the Kansas legislature made provision for a committee of three, one to be elected by the Senate, one by the House, and one appointed by the Governor, "to investigate in the most searching way the business management of every institution and department in Kansas."

In a so-called "partial" report, made in December, I9ı6, this committee recommended a scientific budgetary procedure for the state, and various other changes of the state's administrative system, including the creation of a commission on administration dealing with educational, charitable and correctional institutions; a uniform system of accounting; a central store and purchasing agent; and the consolidation of all agencies pertaining to agriculture into a department of agriculture.

In I9I 7 it made a special report on the educational institutions of Kansas.

In the same year, Mr. J. O. Joseph, Senate member of the committee, printed a special report giving the results of his personal examination of state institutions and departments and his recommendations for reform. Appended to his report were drafts of bills prepared by him having for their purpose the putting into effect of his recommendations. They related to such matters as a budget system, a central stores system, uniform accounts, appointments for fitness and removal for incompetence and procedure in the offices of the state treasurer and auditor. 


\section{AGENCIES OF PARTICULAR STATES, OFFICIAL}

\section{PUBLICATIONS}

Partial report of the Efficiency and economy committee of Kansas.

Dec. 16, I9I6. Topeka, Kansas state printing plant, I9I6. I2 p. Report of the Efficiency and economy committee on the educational institutions of Kansas. [Topeka? I9I7?] I2 p.

Report of the Efficiency and economy committee on the penal, charitable and other institutions of Kansas. [Topeka? I9I7?] Io p.

Economy and efficiency report of Senator I. D. Joseph, senate member of Efficiency and economy commission. [Topeka, I9I7.] 76 p. fold. map, fold. charts.

Alabama: Legislative Investigating Committee. In I9I5 the legislature of Alabama provided by joint resolution for the creation of a "Legislative Investigating Committee," with the duty of investigating and reporting the steps that should be taken to put the administration of governmental affairs upon a more efficient and economical basis. This committee, after examining over twelve hundred witnesses and making special inquiries regarding the conduct of public affairs, submitted its report on July I 3 , I9I 5 .

Upon the fiscal side the committee found conditions to be exceedingly unsatisfactory. The report reads:

An examiner of accounts, as he goes from department to department, is confronted with different conditions and different systems. A lack of uniformity results in a loss of efficiency. Embezzlement of public funds, unauthorized expenditures of public moneys, gross extravagances, misuse of official trust, and graft, large and petty, to which we shall hereafter call attention, can for the most part be traced to a total lack of system. A business corporation or man, following similar methods, would meet certain bankruptcy. . . . Our first recommendation, therefore, is that there be employed, through a commission provided for in a bill herewith submitted, the most competent certified public accountant that can be obtained; that this accountant be authorized to put the State of Alabama on a systematic basis at once, that the bookkeeping, the payment of funds, the record of receipts and disbursements be modernized, simplified; and made uniform throughout all the departments of the state and throughout such offices of the counties as handle state funds, and as are subject to state supervision. 


\section{EFFORTS FOR ADMINISTRATIVE REFORM}

The report then goes on to recommend the establishment of a state budget system, submitting a draft of a bill for the purpose.

Other recommendations deal with fidelity bonds, codification of the laws, public printing, convict labor, immigration, state purchasing, confederate pensions, and some other matters. Especially unsatisfactory were the conditions found in the Department of Agriculture and Industries. "In this Department," the committee says, "we have found evidence of spoil, graft and corruption. The department of pure food and drugs during the past four years, instead of being used for the purpose of protecting the public from impure foods and drugs, has served as a means for a systematic scheme of robbery and thievery."

In conclusion the committee asks that it be continued in order to complete its investigations.

\section{PUBLICATIONS}

Report of the Legislative investigating committee to the Legislature of 1915. July I3, I9I5. Montgomery, Brown printing company, state printers, 19I5. 58 p. (Legislative document No. 13.)

A summary of the report was printed in the Montgomery Advertiser, July I4, I9I5.

Contents.

General conditions.

State budget system.

Legislative.

Code commissioner.

Convict department.

Department of agriculture and industries.

Immigration department.

State game and fish commissioner.

Attorney General's office.

Educational department.

Military department.

Railroad commission.

Archives and history department.

Expenditures for printing.

State purchasing department.

Miscellaneous.

Colorado: Survey Committee of State Affairs. In I9I 5 the legislature of Colorado provided for the establishment of a committee with the function of making a survey of the organization and methods of business of the state government 
with a view to the formulation of suggestions having for their purpose the improvement of the manner in which public affairs were being conducted. ${ }^{1}$ This committee called to its assistance experts in administration in various fields and undertook a very systematic survey of the state government and its methods of administration. In addition to submitting certain special reports it submitted in December, 19I6, a "Summary of Findings and Recommendations relating to the Executive Branch of the State Government of Colorado," which, though brief, was a very able diagnosis of the ills of that branch of the government and contained excellent recommendations for their correction.

Among the latter the most important were for the integration of the administrative services, the increase in the powers of the Governor as head of the administration, and the introduction of a scientifically devised budget system.

Recommendations were also made with regard to accounting, auditing, and reporting of public revenues and disbursements, and the custody of public funds; with regard to the regulation and supervision of labor, the control of corporations, public works, purchasing methods, care of dependents, delinquents and defectives, the protection of game and fish, and with regard to a number of other services and activities of the state.

The Survey Committee also issued in 1916 a report on "The Work of the Colorado Tax Commission," prepared for it by Professor R. M. Haig, of Columbia University, with a letter of comment by Professor E. R. A. Seligman. The abolition of the Tax Commission was then under consideration in the Colorado legislature, which action Professor Haig deemed would be unwise, the accomplishments of the commission fully justifying its continuation. In this conclusion Professor Seligman concurred.

For the purposes of discussion, but without any recommendation, the Survey Committee issued in I9I7 the draft of a highway law for the state.

${ }^{1}$ Colorada, Acts, 1915, Ch. I6I. 


\section{PUBLICATIONS}

Reports. [Prepared for the Survey committee of state affairs of Colorado.] [Denver, Brook-Haffner press.] I9r6.

No. I. Report on a survey of the Office of governor of the state of Colorado.

No. 2. Report on a survey of the Office of secretary of state and on public control of corporations, including Public utilities commission, state bank Commissioner, Department of insurance, Bureau of building and loan associations, General corporation licensing and control, commission merchant inspectors ...

No. 3. Report on a survey of the Office of auditor of state and of the Office of public examiner.

No. 4. Report on a survey of the Office of state treasurer.

No. 5. Report on a survey of the State auditing board.

No. 6. Report on a study of state finances and budget procedure.

No. 8. Report on a survey of the administration of public service functions relating to regulation and supervision of labor.

No. 9. Report on a survey of the Department of game and fish.

No. II. Report on a survey of the Office of the state inspector of oils.

No. I3. Report on the revenue system of the state of Colorado; criticism and suggestions [by R. M. Haig].

No. I6. Report on care of dependents, delinquents and defectives including reports on The care and treatment of the insane of Colorado, by S. W. Hamilton; A study of the mental condition of the four Colorado institutions for minors, by $W$. S. Treadway; The management of three Colorado institutions for minors, by Alexander Johnson; The State board of charities and corrections, by Alexander Johnson.

No. I8. Summary of findings and recommendation relating to the executive branch of the state government of Colorado as submitted to the Survey committee of state affairs of Colorado by its staff. Dec., I9I6. $48 \mathrm{p}$.

Draft of a proposed highway law for Colorado prepared under the direction of the Survey committee... [Denver, I9i6?] $23 \mathrm{p}$.

The work of the Colorado tax commission. A report prepared for the Survey committee of state affairs, state of Colorado, by Robert Murray Haig . . . with letter of comment by Edwin R. A. Seligman ... n. p., I9I6. 54 p.

Virginia: Commission on Economy and Efficiency. An act approved March I6, I9I6, provided for the appointment of a commission to be composed of a member of the Senate, 
two members of the House of Delegates and two citizens to be appointed by the Governor, which should be charged with "the duty of making a careful and detailed study of the organization and methods of the State and local governments of the Commonwealth of Virginia and with reporting to the next General Assembly of Virginia in what way the state and local governments can be more efficiently and economically administered."

This commission, though it had but a short time in which to make its investigations and had at its disposal only the small sum of $\$ \mathrm{I}, 000$, submitted to the legislature on January 9, I9I8, an unusually able report. This report does two things: it furnishes, through the use of outlines and charts, a comprehensive picture of the organization of the state government, and sets forth in succinct form its recommendations of the steps to be taken to improve the administration of public affairs.

The first of these, the report points out, reveals at a glance "the administrative weaknesses of our constitutional form of government. Authority and responsibility are diffused instead of being placed where a definite official can be held to account for the administration of the state's affairs. The people elect a group of purely administrative officers who are responsible in actual practice to no one, these officials being accountable in the same way the Governor is, but are not of sufficient importance to the average citizen for him even to remember the name of the official two weeks after the elections. Another group of similar officials are elected by the General Assembly. There are next a vast variety of offices, some of a purely local character, that are filled by the Governor. Numerous special boards, commissions, bureaus and other agencies, some exercising large powers, are tacked on here and there to our governmental structure, and duplication of functions and overlapping of work and powers occur in many instances."

Centering its attention on the more important causes of the unsatisfactory condition of affairs which it found, the commission adverted first of all to the manner or method by which the administrative system had been built up. "A large number of departments, bureaus, or other agencies have been 


\section{EFFORTS FOR ADMINISTRATIVE REFORM}

added to the constitutional structure from time to time without regard to functional relation to existing agencies. No attempt has been made to coördinate functions, make adjustments, nor establish proper executive control."

The commission, therefore, strongly urged an increase in the controlling powers of the Governor, making him in fact the effective head of the administrative service.

A better supervision and standardization of accounts, the abolition of fees, collective purchasing, self-insurance of state buildings, and centralization of educational control were among the other recommiendations of the commission.

As in the case of most of the state commissions of economy and efficiency, first place, however, was given to the recommendation for the adoption by the state of a proper budget system. After a study of the budgetary legislation of all the other states, the commission prepared the draft of a bill providing for such a system and had the satisfaction of seeing it unanimously adopted by the legislature without change. This result was in no small degree due to the strong support given to the bill by the Governor, Hon. Westmoreland Davis, who, indeed, had made his campaign for election on this issue.

\section{PUBLICATIONS}

Report of the Commission on economy and efficiency to the General assembly, January 9, 1918. [Richmond, Richmond press, inc., printers. I9I8.] 67 p. 3 fold. diagrs.

Contents.

General plan of work.

Outline of the functional organization of the state government.

Organization of the legislative department [with chart].

Organization of the judiciary department [with chart].

General outline of the organization of the executive department [with chart].

Budget system.

Supervision of accounts.

Standardization of expense accounts.

Uniform fiscal year.

Abolition of fees.

Uniform office hours.

Leave of absence.

Special attorneys and inspectors.

Location of offices.

Public buildings and grounds.

Collective purchasing.

State insurance. 
Civil service.

Study af the public school system of Virginia.

Commission on economy and efficiency.

Louisiana: Board of State Affairs. On July 5, I9I6, Louisiana passed an act providing for the creation of a body to be known as the Board of State Affairs. Though this board was created in the first instance to take over the duties of the State Board of Appraisers and the State Board of Equalization, which were abolished, it had conferred upon it new powers which, in effect, made of it an official economy and efficiency board with the duty of investigating and submitting recommendations regarding the organization and administration of all government departments and institutions, and also a budgetary organ with the duty of preparing the budget of revenues and expenditures for consideration by the legislature. It is composed of three members appointed by the Governor, by and with the advice and consent of the Senate, for a term of six years.

The statute creating this board, in addition, as above stated, to making it the organ for formulating the budget, declares that it shall be the duty of this board:

( I) To investigate duplication of work of public bodies, the efficiency of the organization and administration of such public bodies and to formulate and recommend to the General Assembly plans for the greater coördination of such public bodies and the improvement of state administration in general.

(2) To investigate the feasibility of a central Board of Control for all public educational institutions, the same for all public charitable and eleemosynary institutions; with particular respect to the business administration of such institutions. printing.

(3) To investigate the efficiency and cost of state

(4) To investigate and report upon the feasibility of establishing a central purchasing, sales and exchange bureau, under the control and direction of this Board, for the purpose of purchasing all supplies and materials for and selling or exchanging all the products of, such public bodies.

(5) To investigate other matters for the purpose of bringing about greater efficiency and economy in every public 


\section{EFFORTS FOR ADMINISTRATIVE REFORM}

body advancing the economic betterment of the state, and of promoting the public welfare.

The results of the investigations herein required shall be printed and placed in the hands of the members of the General Assembly and the heads of all public departments and public institutions at least sixty (6o) days before the meeting of said General Assembly in I9I8; and, at the discretion of the Board, such reports shall be biennially made thereafter.

\section{PUBLICATIONS}

First annual report of the Board of state affairs ... for the year 1917. April 15, 1918. Baton Rouge, 1918. 366 p.

Bound with this: Legislative recommendations made by the Board of state affairs to the General assembly of Louisiana for the regular session of 1918. Baton Rouge, 1918. $37 \mathrm{p}$.

\section{Texas: Joint Legislative Investigating Committee. In} I9I7 the two houses of the legislature of Texas, by separate resolutions, provided for the creation of committees of three members each to make a thorough investigation of all the departments of the government and state institutions and to report their findings with recommendations. These two committees, which met as a joint legislative committee, made their inquiries in conjunction with each other and submitted on February I, I9I8, a joint report to the two houses. In this report each department and state institution is considered in turn. In the case of practically all they found room for great improvement, and radical measures of reform were submitted. The report estimated that if its recommendations were adopted a saving of nearly a million dollars annually would be secured.

In prosecuting its inquiries the legislative committee made use of ten subcommittees. It is reported that the reports of these subcommittees, which make a more detailed showing of conditions than does the report of the parent committee, are in process of being printed and will shortly be available for distribution.

\section{PUBLICATIONS}

Report of the Committee of the Senate and the Central executive committee of the House of representatives, composing a legislative committce to investigate the departments of the state gov- 


\section{AGENCIES OF PARTICULAR STATES, OFFICIAL}

ernment and the state institutions ....Feb. I, I9I8. [Austin, 1918.] $58 \mathrm{p}$.

Published also in [Texas] House journal, March II, 1918, p. 26I-9I, with title: Joint report of central investigating committee appointed by the Senate and House of representatives of the Thirty-fifth legislature.

Oregon: Consolidation Commission. Under a resolution enacted by the legislature of Oregon in 1917 there was appointed by the Governor a Consolidation Commission composed of seven business men for the purpose of conducting "thorough investigation of the several offices, boards, commissions and departments of the state as to the scope, nature and importance of the different branches of the work performed by each, and that the above mentioned commission be required to make a complete and comprehensive report of its findings, together with such recommendations as to consolidation, economy and efficiency, as they may find feasible, to the next regular session of the legislative assembly." The commission employed an expert to make the actual investigation of the administrative departments and to formulate its report. The commission found that no efficient and businesslike administration of state affairs in Oregon could be expected unless some one officer, who should be fully responsible to the people, could control all the important departments of the administration. It was held that the Governor was the logical officer to fill this position, but he did not do so under existing conditions because, in the first place, the administration was split up into too many departments for the Governor to exercise adequate control over them, and, in the second place, there were too many elective officers, with the result that there were in reality many governors in the state instead of one. In order to remedy the first of these difficulties, the commission recommended that the separate administrative agencies, of which there were about seventy which had been created by the legislature from time to time without system or coördination, should be consolidated into eleven main departments, which should include all such agencies with the exception of the proposed state civil service commission and the state police. In order to remedy the second of these difficulties, the commission recommended that, in so far as feasible within the limits of the con- 
stitution, the short ballot should be introduced through the elimination of unnecessary elective officers.

One of the most pressing problems in Oregon for some time has been that of the proper organization of state control over its institutions of higher education. The State University, the State Agricultural College and the State Normal School are located at different places in the state, the situation in this respect being similar to that in Iowa. The question has been whether to continue the separate boards or to consolidate the institutions under the control of a single board. The report of the commission, as formulated by its expert, recommended that what was called the "three-in-one plan" should be introduced as a compromise, whereby there should be a state board of education of nine members, to be composed of three institutional committees of three members each, one committee for each of the three institutions. These committees were to appoint the presidents and faculties of their respective institutions and to attend to local and special matters, while the three committees together, composing the whole state board of education, were to attend to matters affecting more than one of the institutions, such as formulating requests for any appropriations needed above the proceeds of the millage tax and taking over the functions of the Board of Higher Curricula in eliminating, so far as possible; duplication of work among the several higher educational institutions.

The commission also recommended the adoption of an executive budget system. Its recommendations on this head were as follows:

There should be concentrated responsibility for the estimates, and this can properly be assumed only by the governor, as the head of the administration. It is, therefore, recommended that the preparation of the budget and its transmission to the legislature be placed in the hands of the governor, or in those of some officer appointed by him, and subject to his supervision and control. If the governor is to be required to assume the responsibility for the estimates in the budget, it follows as a logical corollary, that he must be provided with adequate means for scrutinizing the estimates as they come to him from the heads of departments, and for giving them study and criticism, so as to prune them to the proper proportions I60 
in view of the general financial condition of the state. It is recommended that the state tax commissioner, who is an appointee of the governor and subject to his control, should be entrusted with the preparation of the budget under the supervision of the governor. The tax commissioner should be furnished with the necessary clerical assistance in compiling the estimates. When finished, however, the budget should be transmitted to the legislature with the authority of the governor behind it.

Other States. As has already been stated, the legislatures of the several states are all the time creating special committees to investigate and report upon the work of particular departments of the government and state institutions. It is manifestly impracticable, even to list, and much less to describe, the work of all of such committees. Mention might, however, be made of the following committees, the appointment of which has come to the attention of the author in the preparation of this report.

The legislature of South Dakota provided for the appointment of a Joint Committee on Investigation of State Expenditures and the System of Accounting and Reporting. The report of this committee was made in 1915 and was published in the Journal of the House, February 25, I9I 5.

Mississippi provided for a joint committee of the two houses of the legislature to investigate its several administrative departments and state institutions, the report of which was published in I9I 3 in a pamphlet of I 32 pages.

The Ohio legislature in I9I 5 provided for a similar committee to investigate state departments and institutions, the report of which was published in Volume V of the Senate Journal, I9I 5 . 


\section{CHAPTER IV}

\section{AGENCIES FOR INVESTIGATING THE ADMINIS- TRATION OF PARTICULAR STATES : UNOFFICIAL}

Comparatively little progress has been made in the way of the establishment under unofficial auspices of institutions having for their sole purpose the promotion of efficient state administration. There is, in fact, no institution coming properly under this head. The two agencies described in the subsequent paragraphs of this chapter are included merely because of their close relation to the problem of state administration. One concerns itself chiefly with matters of legislation; the other was a temporary body created to investigate the problem of budget reform.

In the succeeding chapter, however, account is given of two agencies which attempt to occupy the field of state and municipal administration simultaneously. In addition, note should be taken of the fact that some bureaus of municipal research, in spite of the fact that they have been established primarily for the purpose of improving methods of administration of particular cities, have concerned themselves to a greater or less extent with matters of state administration. This is particularly true of the New York Bureau of Municipal Research, whose activities in this field have been very important.

New Jersey: Bureau of State Research, State Chamber of Commerce. The State Chamber of Commerce, organized in 1912, has for its primary object to provide its members and the citizens of New Jersey with facts affecting the public welfare.

The membership consists of two classes of individual members, sustaining and associate, limited in number, and dis- 
tributed over the state according to population as apportioned by the congressional district. The number eligible to each class of membership is determined by the fixed ratio of one member to five thousand population. Civic, commercial or agricultural associations of New Jersey may become affiliated in the chamber as federated members. The annual dues of sustaining members are $\$ 100$ and of associate members $\$ 25$. Its headquarters are at Newark.

In I9I 5 the Bureau of State Research was organized as a separate department of the chamber and given primary charge of investigations and the collection of information. It has a director, an advisory committee, a secretary, and a staff of trained investigators.

The work of the bureau has consisted, in the main, of publishing a weekly Legislative Index during the annual session of the legislature, supplying special legislative service, analyzing bills, and conducting legislative investigations throughout the year.

In the preparation of the Legislative Index, expert investigators are in attendance at Trenton and report the procedure of all sessions of the legislature. The reports of these investigators are published each week in the form of brief digests of the contents of each bill introduced, and a record of each step of its progress, and a current subject index of these bills are kept. The Legislative Index also contains each week an analysis of some one or more of the important measures before the legislators. The Legislative Index thus serves as a medium by which citizens can watch legislation.

In addition to the information contained in the weekly Legislative Index, a daily service is furnished to a number of civic organizations and individuals throughout the state, whereby information is given on form cards from day to day of the progress of measures in which the recipients are particularly interested. These cards are marked and mailed to the recipients direct from Trenton by the bureau's investigators in attendance at the meetings of the legislature. In some instances this information is conveyed by telephone.

Investigations are made by the bureau from time to time of as many subjects awaiting study as can be handled. These 


\section{EFFORTS FOR ADMINISTRATIVE REFORM}

investigations are intended to bring out such facts as will establish bases upon which the Chamber of Commerce can make recommendations to the legislature. The regular program of investigations of the bureau is determined each year by the trustees of the Chamber of Commerce.

Since its organization the subjects of investigation by the bureau have been: the state rural police patrol, corporation audits, the state budget, the Torrens system, workmen's compensation, the "full-crew" law, and good roads.

A bill designed to create a state police in New Jersey similar in character to that which has existed in Pennsylvania since 1905 was introducted at the legislative session in I9I4 and again in I9I5. To supply the information necessary to act intelligently upon this proposed legislation, statistical data were tabulated by the bureau, showing the prevalent crimes in each county and the number of unapprehended criminals, the opinions of the prosecutors of the pleas, the sheriffs and the granges, and a record was made of the causes and extent of forest fires, so that a complete analysis for the entire state could be made of the existing need, if any, for a rural patrol.

In view of proposed legislation designed to protect investors in the securities of New Jersey corporations by requiring the regular examination of the books of all corporations by certified public accountants, to be elected by the stockholders, a study was made by the bureau of this entire subject, and it was found that any legislation of this character would conflict at so many points with the existing statutes that it would be advisable to make a complete investigation of the present control and regulation of New Jersey corporations before introducing any new elements of uncertainty into an already complicated situation.

To facilitate the practical operation of the budget system which was provided for by law in I9I 5 ; and to eliminate many evils of the old system, the bureau has tabulated the itemized appropriations of 1914 , I9I5, and I9I6 in order to show the variations which occur from year to year in the distribution of the state's revenue. The State Chamber, by calling attention to New Jersey's antiquated fiscal procedure through its publications and the daily press, has been instrumental in 
creating a state-wide sentiment for this advanced piece of financial legislation.

At the request of the Real Estate Board and the BuildingLoan League the bureau made an analysis of a bill which would allow any New Jersey owner the option of registering his title under a Torrens law. This analysis was accompanied by a brief history of the Torrens Acts and a resumé of the decisions of the courts on their constitutionality in the several states.

The matter of workmen's compensation had the attention of the state of New Jersey for several years, and the State Chamber gathered facts pertinent to a complete and unbiased consideration of the question.

The State Chamber has conducted a thorough investigation of the operation of the "full-crew" legislation, with particular reference to the law in New Jersey.

The State Chamber is endeavoring to find out the exact road conditions brought about by modern conditions in order to recommend to the legislature an efficient road policy.

The New Jersey Chamber of Commerce issues a weekly bulletin, a feature of which is the Legislative Index above mentioned. It has issued several printed reports of investigations and pamphlets and folders explaining its work.

PUBLICATIONS

State research ... Consecutive numbers.

Contents

No. I. The administration of the full-crew law, etc., 1917. I3 I $\mathrm{p}$.

No. 2. The state police problem in America. I9I7. 210 p.

No. 3. The New York state troopers. Oct. I9I7.

No. 4. The operation of the New Jersey budget law. Oct. I9r 7 .

No. 5. [State officials.] Nov. I9I7.

No. 6. The Pennsylvania state police. Nov. I9r7.

No. 7. Unknown.

No. 8. Report of the pension and retirement fund commission. Dec. I9I7.

No. 9. Why New Jersey needs a state police. Dec. I9I7.

No. Io. Teachers' retirement systems in New Jersey, their fallacies and evolution. Introduction and part I. Feb. I9r8.

No. II. Police, firemen's and other local employees' pension systems in New Jersey. Feb. I9r8. 
Legislative and investigative work completed and planned, I9I6.

A state highway system versus old laws and good roads. July, IgI6. I6 p.

Maryland: Commission on Economy and Efficiency. The Maryland Commission on Economy and Efficiency was of a unique character due to the unusual circumstances under which it was created. Both the Democratic and Republican parties in their campaign of I9I 5 pledged themselves to support the introduction of a budget system for the state. The Democratic Convention, however, went further than this, and provided for the creation of a Commission on Economy and Efficiency which should have as its special work the devising of a specific proposal for the accomplishment of this reform. This commission was duly constituted with President Frank J. Goodnow of the Johns Hopkins University as its chairman.

This commission made a brief but exceptionally able report which the Democratic Governor, Emerson C. Harrington, transmitted to the Senate, recommending favorable action upon its recommendations. The report though emanating from a private body was thus published as a public document. This report led to the adoption by Maryland of an amendment to the state constitution providing for the introduction of a budget system.

\section{PUBLICATIONS}

Report of the Commission on economy and efficiency on a budget system. Jan. 28, 1916. (In Baltimore. Dept. of legislative reference. The Maryland budget amendment. I9I7. p. 7-13.)

Reprinted from the Maryland Senate Journal, Jan. 28, I9I6, p. I29-34.

Other States. The foregoing it is believed represent all agencies which have been created by private effort having for their principal purpose the study of the problem of state administration with a view to the promotion of measures of reform. Other privately organized bodies, however, give more or less attention to this subject. Among these special mention, by way of illustration, might be made of the Taxpayers Associations of California and New Mexico. 


\section{CHAPTER V}

\section{AGENCIES FOR INVESTIGATING THE STATE AND LOCAL ADMINISTRATION OF PARTICULAR STATES: UNOFFICIAL}

In two states-Ohio and Maryland-unofficial agencies have been created for the study of both the administration of state and local affairs in those states. This type of unofficial organization is of especial interest in that no official agency of the same scope has been established by any state; although as will be set forth in a subsequent section official reference services covering both the state and municipal field have been established in several states.

Ohio: Institute for Public Efficiency. The Ohio Institute for Public Efficiency was incorporated in I9I3 and began operations in January, I914. The governing body of the institute is a board of nine trustees. Its headquarters are at Columbus.

The work done for state administration and legislation is supported by contributions of public-spirited citizens and organizations; work done for counties, municipalities and school districts is paid for by local authorities, organizations or individuals. The purpose of the organization, as stated in its articles of incorporation, is: "To advance public welfare (I) by promoting the efficiency and adequacy of government, through the ascertainment and application of scientific standards and principles and otherwise; (2) by continually and systematically informing public opinion upon public affairs; (3) by promoting the coöperation, coördination and efficiency of civil, social, and charitable organizations; (4) by educating persons in the theory and practice of public efficiency and preparing them for efficient public service; and by any other means that may be deemed proper and necessary." 


\section{EFFORTS FOR ADMINISTRATIVE REFORM}

Two departments have been organized, namely, the Accounting and the Social Service Departments, each in charge of a director.

The Accounting Department devotes its principal efforts to perfecting and installing efficient accounting, budget, purchasing methods, etc.

The object of the Social Service Department is the "promotion of a program for Ohio leading to: (I) ultimate elimination, as far as possible, of dependency and delinquency as forms of social waste; and (2) the establishment of progressively higher standards of living." This is done by "investigation of conditions underlying and causing dependency, delinquency, and low standards of living; framing and promoting measures for the removal of such causes; and promoting efficiency of administration in public and private institutions, departments, and agencies which affect social conditions."

The most important items of work done by the institute since its organization, either under engagement for local civic and social organizations, or directly upon its own responsibility, have been as follows:

With the coopperation of the county auditor and treasurer, a study was made of the Cuyahoga County accounting methods for the Cleveland Civic League, and recommendations for an improved system were presented.

An analysis of the financial conditions and a review of the general organization and methods of the Cleveland Associated Charities were made for that organization and the Cleveland Federation for Charity and Philanthropy. Recommendations relating to accounting and reporting methods were approved and adopted.

An improved general municipal accounting system was outlined for Akron, Columbus and Toledo. Based on this outline, a procedure using recent labor-saving devices was installed by the institute in Akron in behalf of the Akron Bureau of Municipal Research. A longhand procedure worked out by the State Bureau of Accounting was installed by it in Columbus and Toledo.

New budget estimate methods were prepared for Columbus and Toledo, which were substantially adopted. 
Extensive coöperation was afforded the State Bureau of Accounting in the preparation of a new standardized classification of expenditures, adapted for use by state departments, cities, counties, school districts and townships. The elasticity of this classification enables it to be contracted or expanded according to the needs of the governmental unit classifying it. The new classification is now in use in three cities and one school district and is to be promulgated for all Ohio cities.

The principal features of centralized purchasing procedure were outlined and submitted to the new central purchasing departments created by charter in Columbus and Toledo.

An analysis of the financial condition of the city of Toledo was prepared for, and published by, the Toledo Commerce Club. A similar analysis for Columbus was published by the Columbus Bureau of Municipal Research.

A recommendation for a more definite policy in municipal electric light plant expenditures in Columbus was supported by the Chamber of Commerce and acted upon favorably by the city council.

A recommendation was made to, and approved by, the Columbus City Council, for doing away with unnecessary surety bonds.

A study of certain phases of public school policy was made for the Columbus Chamber of Commerce.

City charter studies were made for the Cincinnati Bureau of Municipal Research.

An analysis was made for the Marion Township Manufacturers Association of the causes for the marked increase in the tax rate in that township.

With the coopperation of the state librarian and his staff, a study was made and submitted of the functions, organization, and procedure of the state library.

A clearing house has been organized for information concerning current civic and social activities in Ohio.

As indicated above, the services of the institute have been employed by the following organizations: The Civic League of Cleveland, the Cleveland Federation for Charities and Philanthropy, the Cleveland Associated Charities, the Toledo 


\section{EFFORTS FOR ADMINISTRATIVE REFORM}

Commerce Club, the Columbus Chamber of Commerce, the Columbus Bureau of Municipal Research, the Cincinnati Bureau of Municipal Research, the Marion Township Manufacturers Association, and the Akron Bureau of Municipal Research.

The institute in the course of its work has met with the cooperation of most of the public officials with whom it has had to do, and a number of its recommendations have been approved and acted upon.

Through the Department of Social Service, whose operations began July I, I9I6, the institute initiated a campaign for the more adequate care of the feeble-minded and preventive control of feeble-mindedness; conducted a study of the local conditions of Portsmouth, Ohio, and made recommendations with respect to charitable relief, delinquency, housing and health; and, in coöperation with the Industrial Commission, prepared bills and urged legislation to regulate more satisfactorily the private labor agencies and prohibit job selling in industrial establishments.

\section{PUBLICATIONS}

First annual report of the Ohio institute for public efficiency for the year ending October 3I, I9I4. (typewritten). $6 \mathrm{p}$.

Second annual report .... for the year ending October 3I, I9I5. [5] $\mathrm{p}$.

Third annual report . . . for the year ending October 3I, I9I6. I4 P. Fourth annual report . . . for the year ending October 3I, I9I7. I5 p. Financial statement as at October 31, 1916. Folder.

Social legislation enacted by the eighty-second General assembly of Ohio. April, I9I7. [5] p.

Accounting program.

Social service program.

Toledo city finance.

[Leaflets relating to mental defect as cause of dependency and delinquency.]

For example.

Mental disorders.

Ohio's 80 per cent deficit.

Speaking of economy-look at Anne's board bill.

Three generations.

Too many husbands to remember.

ARTICLES

Croxton, Fred C. The Ohio institute for public efficiency; its relation to health departments. Other public health journal, Feh., I9I7, v. 8: 73-75. 
Miles, Rufus E. The Ohio institute for public efficiency. IgI6. $12 \mathrm{p}$.

Reprinted from "Citizen agencies for research in government," the issue of Municipal research, No. 77, for Sept., I9I6.

Social community planning for Ohio. Survey, July I5, 1916, v. 36: 413.

Maryland: Bureau of State and Municipal Research. The Bureau of State and Municipal Research, located in Baltimore, Maryland, was organized in the fall of I9I2. It was never incorporated but has conducted its work under the immediate direction of the principal contributors. The organization has followed the usual bureau methods and has attempted efficiency studies in connection with city departments and state institutions. It has also done considerable work in connection with investigations for local social bodies.

The scope of the bureau's activities is indicated by the following list of its reports.

\section{PUBLICATIONS}

Report No. I-Baltimore, I916-

No. I. The inspection of weights and measures in Baltimore city. 1916. $30 \mathrm{p}$.

No. 2. The Baltimore budget.

Part I. A study of the ordinances of estimates from 1900 to I9I3. [13] p.

No. 3. The Business organization and methods of Springfield state hospital for the insane. 1913.

No. 4. City of Baltimore, balance sheets I9II, 1912; General accounts 1912, I913. I3 p.

No. 5. Institutional supplies. I9I3. 64 p.

No. 6. Accounting in the appeal tax court and collector's office. I9I3.

No. 7. Business methods of the Baltimore police department. 1917. 3I p.

No. 8. Organization and work of the Office of the inspector of buildings. I9I3-I9I4. 2 parts. ms.

No. 9. Accounting methods of Baltimore city as illustrated in the report of the Comptroller. II3. ms.

No. Io. The purchase of coal by institutions. 1914. $66 \mathrm{p}$.

No. II. (No report issued having this number.)

No. 12. Notes on duties of a municipal purchasing agent. 1915.

No. 13. Baltimore police department. Additional criticisms and recommendations with proposed changes in forms, records and clerical procedure. 19I6. $\mathrm{ms}$.

No. 14. Present and proposed methods of handling records of arrests. IgI6. ms. 


\section{EFFORTS FOR ADMINISTRATIVE REFORM}

No. 15. Part I. Districting of Baltimore for the work of charitable institutions.

Part II. The enumeration districts. 1917. I9 p. plates. Bureau of state and municipal research; an organization devoted to

the promotion of efficiency in public business. Baltimore [1913]. I4 P., II.

Four years of prosperity. Baltimore [19I7]. [4] p. 


\section{CHAPTER VI}

\section{AGENCIES FOR STUDYING MUNICIPAL ADMINIS- TRATION GENERALLY : UNOFFICIAL}

It is a striking fact that despite the interest which has long obtained in the problem of improving municipal administration in this country, no organization has yet been created which has for its sole purpose the study of that problem generally, without special emphasis on the problems of any particular city. The agency of which account is given belowthe New York Bureau of Municipal Research-comes very nearly within this description; but it has hitherto devoted so much of its attention to the government of New York City, that the propriety of its inclusion under this head is perhaps open to a measure of doubt.

New York: Bureau of Municipal Research. So important is the part which has been played by the New York Bureau of Municipal Research in the development of the governmental research movement in this country, of which it was the pioneer, that a somewhat full account of its origin and history seems justified.

The facts regarding the origin of the bureau were set forth in a statement prepared by the bureau and filed with the late U. S. Commission on Industrial Relations that was presided over by Mr. Frank Walsh. This statement in part reads :

In its issue of March II, I9OI, this [the idea of establishing a citizens' agency to coöperate with city officials in improving methods of administration] was the subject of an editorial in the New York Tribune which was clipped by $\mathrm{Mr}$. Frank Tucker and sent to $\mathrm{Mr}$. R. Fulton Cutting as something to which he should lend his support. Soon after this a formal proposal to create a bureau or department of civic 


\section{EFFORTS FOR ADMINISTRATIVE REFORM}

affairs of the Chamber of Commerce was prepared by $\mathrm{Mr}$. Tucker, and taken up by Mr. Cutting with Mr. Charles Stewart Smith, a prominent member of that body. When Mr. William H. Allen came to New York his assistance was invited. While engaged professionally on work of this kind, Mr. Frederick A. Cleveland became impressed with the need for an independent agency supported by citizens, which would be equipped to obtain information about the management of public affairs, and follow up and support the constructive measures of public offices. And when Mr. Cleveland became a member of the Mayor's advisory commission on finance and taxation in January, I905, he actually employed an outside staff in this manner.

In February, 1905, Mr. Cleveland prepared a written prospectus for the organization of a permanent "Bureau of Municipal Research," at the suggestion of Mr. Tucker, and placed it in Mr. Allen's hands, with the understanding that he would undertake to raise money for it. This brief was used for some time by $\mathrm{Mr}$. Allen, and several conferences were arranged with professional and business men. Later in November with the help of Mr. Tucker, Mr. Allen prepared a revised statement and circulated it under the title of "Brief for the Establishment of an Institute for Municipal Research." In the latter part of $1905 \mathrm{Mr}$. Cutting decided to support the effort at the rate of \$I,OoO per month for a year, to make an actual demonstration of what could be done, and with this fund $\mathrm{Mr}$. Henry Bruère was employed to take charge of it, taking over on his staff some of the men who had been working with $\mathrm{Mr}$. Cleveland. The work was financed by Mr. Cutting and conducted by Mr. Bruère as the "Bureau of City Betterment," a branch of the Citizens' Union, of which Mr. Cutting was president.

The success achieved led to the decision to incorporate the service as an independent institution. The coopperation and financial assistance of other men were secured and the service was incorporated in May, 1907, under its present title of Bureau of Municipal Research. The membership of the corporation was limited to fifty persons, members to be elected by a majority vote of the board or of the members at any annual meeting or at a special meeting called for that purpose. The management of the business affairs of the cor- 


\section{AGENCIES FOR MUNICIPAL ADMINISTRATION}

poration was entrusted to a board of fifteen trustees, elected from the members of the corporation at annual meetings.

Mr. Henry Bruère was selected as the first director of the bureau with Mr. Cleveland and Mr. Allen as co-directors.

In the articles of incorporation the purpose of the bureau was set forth as follows:

To promote efficient and economical municipal government; to promote the adoption of scientific methods of accounting and of reporting the details of municipal business, with a view to facilitating the work of public officials; to secure constructive publicity in matters pertaining to municipal problems ; and to these ends, to collect, to classify, to analyze, to correlate, to interpret, and to publish facts as to the administration of municipal government.

In I9I I the activities of the bureau were broadened, at least indirectly, by the affiliation with it of the Training School for Public Service. This school, according to the historical note appearing in its announcement for I9I7, was founded by Mrs. E. H. Harriman in the spring of I9II. The note reads :

Seeing the immediate and future need for trained executives to serve governmental agencies and private organizations interested in better government, Mrs. Harriman contributed the sum of $\$ 40,000$ to initiate the preliminary work. Soon she was joined by thirty-five other contributors, men of broad vision and large experience, and a fund of $\$ 200,000$ to carry on the work of the school was guaranteed. The Bureau of Municipal Research was asked to organize and conduct the work, and on October I, I9I I, the Training School for Public Service formally began its existence.

Since then the school has been conducted in close affiliation with, if not directly by, the Bureau of Municipal Research. It has its own funds and officers, but occupies the same quarters as the bureau, and the students get a large part of their practical training in administration through the work done by them on assignments given to them by the bureau and performed under its direction. 


\section{EFFORTS FOR ADMINISTRATIVE REFORM}

The purposes of the school as expressed in its announcements are:

To give to its students a firm grasp upon all the leading problems of modern public administration; to train men and women in modern administrative methods, especially in their relation to public business; to supply public and private bodies with administrators competent to test and improve methods and to produce results; to give graduates of technical and professional schools an opportunity to secure practical experience in the application of their specialties to municipal problems; to furnish a connecting link between schools and colleges and public departments for practical field work; to afford opportünities for advanced students in economics and political science to prepare doctors' dissertations and treatises on specific problems of practical administration; to enable high school, college and university instructors in civics, political science and economics to obtain a first-hand contact with the work of public administration; to publish the results of research in administration; to secure an open discussion of public business which will emphasize the need of training public officials and employees; to help make the public service a profession of equal standing with law or medicine.

The school is under the direction of a committee of the trustees of the Bureau of Municipal Research. The work of instruction and guidance is in the hands of the supervisory staff of the school, the members of the Bureau of Municipal Research and a staff of special instructors.

The training given to students consists of systematic instruction at the Training School, Columbia University, New York University, and other educational institutions in New York City; and field work with the Bureau of Municipal Research and with various public and private institutions, offices, and associations under supervision.

While the charter of the bureau does not in any way restrict its activities to the city of New York, and indeed expressly authorizes it to establish branches in any state or territory of the Union, the bureau has naturally devoted more attention to the improvement of the administration of New York City than to that of any other single city. Particularly was this true in the earlier days of the bureau. It is impos- 


\section{AGENCIES FOR MUNICIPAL ADMINISTRATION}

sible, however, to attempt, in the space at disposal, any detailed account of its activities in respect to the municipal government of New York City. All that can be said is that, for a period of over ten years, it has been working with the officials of that city; that in doing so it has examined into almost all branches of the municipal government; made many concrete suggestions for improvement; and that the value of this work has been repeatedly testified to by the officers of that government. ${ }^{1}$

At the time the bureau was established there were but few persons who had made any special study of the technical problems of public administration. The bureau had to train a special staff of experts in this field. It resulted from this that when the success achieved by the New York bureau led to movements in other cities for the creation of similar bureaus, the persons responsible for such movements have to turn to the New York bureau for assistance. This assistance has been rendered in two ways: in the sending of members of its staff to make what are known as "municipal surveys," that is, investigations and reports having for their purpose to make known existing conditions and the lines along which efforts for reform should proceed; and in furnishing men to take charge of the new bureau when established. This work increased to such an extent that the bureau became a general agency for the furnishing of expert assistance to organizations desiring to make studies of municipal conditions and to formulate plans for their improvement. The work thus done for outside agencies is performed upon a cost basis, that is, the actual cost of the salaries and expenses of the men assigned to the work plus an overhead charge representing a proper proportion of the general expenses of running the bureau.

The charter of the bureau apparently restricts its activities to matters of municipal administration. In point of fact, due either to the extent to which municipal affairs in New York are subject to state control or to other reasons, the bureau has gone beyond the field of municipal affairs and has

${ }^{1}$ For an impressive account of the accomplishments of the bureau since its organization see, A National Program to Improve Methods of Government, Municipal Research, No. 7I, March, I9I6. 
played an important part in promoting administrative reform in the government of the state of New York, and through its publications and the personal efforts of its officers, administrative reform generally in the United States. Thus in the field of state administration, the bureau coöperated with the former Department of Efficiency and Economy in the preparation of an elaborate descriptive study of the organization, functions, personnel and responsibility of each department, bureau and office of the state government. This report was prepared for the use of and was submitted to the State Constitutional Convention of I9I5. Later, the bureau submitted to the Constitutional Convention a report giving a critical and constructive appraisal of the state government, including a discussion of the need for responsible government and the development of executive leadership, a plan for reorganization and reclassification of the state departments and a subjective revision of the state constitution. Two amendments were also prepared, one reclassifying the departments and reducing the number of elective officers, the other providing for a state budget. The bureau thus placed before the convention much material made available for the first time concerning the problems, facts and actual conditions of state government.

The bureau has coöperated with the Senate Committee on Civil Service of the state legislature in an elaborate study of standardization of salaries in the civil service of the state. This resulted in the submission of a report consisting of complete standard specifications, an administrative code for the guidance of the Civil Service Commission, an appraisal to standard grade of every salaried position in the state government, critical reviews of defective organizations in the principal departments, a detailed description of working methods used in reaching the conclusions stated in the report and a pro forma bill authorizing the establishment of the standard titles and rates of pay.

The bureau coöperated with both the Governor and the legislature in attempting to secure executive budget procedure, and assisted in the preparation of bills embodying the principles of budget reform. The bureau also conducted 


\section{AGENCIES FOR MUNICIPAL ADMINISTRATION}

prison surveys at Sing Sing, Clinton, Auburn and Great Meadow, the items of special interest covered being prison industry, prison plants and methods of discipline, and made other special studies in state administration.

It will be seen from the foregoing that the activities of the bureau have been in four fields. It has, in the first place, sought to bring about an improvement of administrative conditions in the government of the city of New York through the prosecution of studies in close coöperation with city officials and the formulation of proposals for improved methods. Secondly, it has coöperated with other organizations in seeking to bring about a better system of administration of state affairs. Thirdly, it has met requests from all parts of the Union for assistance in the organization of local bureaus of municipal research or the prosecution of particular inquiries having for their purpose the improvement of the conduct of public affairs. And, finally, it has coöperated in the maintenance of a school for training men in the principles of public arministration.

The printed publications of the bureau consist of a series of weekly or semi-weekly leaflets entitled Efficicnt Citizenship, of which, it is reported, some 655 have been issued; another series of leaflets entitled Municipal Research, the publication of which was begun in I9I3, of which 56 issues were made up to December, I9I4; a journal bearing the same title, $M u$ nicipal Research, which was begun in January, I9I5, the issues of which were given serial numbers beginning with the number 57 as a continuation of serial numbers of the leaflets similarly entitled; and miscellaneous reports. The periodical Municipal Research was discontinued as a monthly at the end of I9I7, but will continue to appear at irregular intervals.

Following is a list of the publications of the bureau as given on the cover sheets of the last issue of Municipal Research, with the exception that certain titles representing the work of officers of the bureau, but not published by the bureau itself, have been eliminated. 


\section{EFFORTS FOR ADMINISTRATIVE REFORM}

PUBLICATIONS

Books and Pamphlets

1907

A department of municipal audit and examination; report of an investigation of the office of Commissioners of accounts New York city. [New York, I907.] 35 p. incl. tables.

Making a municipal budget, functional accounts and operative statistics for the Department of health of Greater New York. [New York, I907.] I7I p. incl. forms.

Purposes and methods of the Bureau of municipal research. [New York, 1907.] $28 \mathrm{p}$.

\section{I908}

Memorandum of matters relating to New York city's debt that suggest the necessity either for judicial ruling or for legislation, submitted by the Bureau of municipal research to the referee and counsel in the suit of Jefferson M. Levy versus Board of estimate and apportionment; to the sub-committee on finance, accounting, etc., of the New York charter revision commission; and to counsel to the joint legislative committee appointed to investigate the finances of the city of New York. [New York], rgo8. 3I p. incl. tables, fold. tab.

New York city's Department of finance. Pt. I-Submitted to the Hon. Herman A. Metz, comptroller, by the Bureau of municipal research... New York. I908.

Contents.

Part. I. Report on present methods, with suggestions for reorganization. $254 \mathrm{p}$.

The park question ... New York. I908. 2 v. front. (v. 2) plates, tables, fold. diagrs.

Contents.

Pt. I. Critical study and constructive suggestions pertaining to administrative and accounting methods of the Department of parks: Manhattan and Richmond. I52 p.

Pt. II. Critical study and constructive suggestions pertaining to revenue and deposits of the Department of parks: Manhattan and Richmond. $124 \mathrm{p}$.

1909

Business methods of New York city's Police department; summary of critical study and constructive suggestions pertaining to administrative and accounting methods of the Bureau of repairs and supplies. Based upon inquiry requested by Police commissioner Bingham. July, I908, and pursued from August, I908, to April. I909, with the coöperation of William F. Baker, now police commissioner and then first deputy ... [New York, I909.] 35 p. IV fold. diagr.

Collecting water revenues, methods of the Bureau of water register, Manhattan, with suggestions for reorganization, submitted in I80 


\section{AGENCIES FOR MUNICIPAL ADMINISTRATION}

November, 1908, to the Commissioner of water supply, gas and electricity. New York, 1909. 223, [6] p. fold. plan, facsims., 2 fold. diagr.

How should public budgets be made? How budgets have been made, how budgets are made, how budgets should be made, fourteen stages in budget making. [New York], I909. I9 [I] p. incl. facsims.

New York city's debt; facts and law relating to the constitutional limitations of New York's indebtedness; a brief of the evidence taken by Hon. Benjamin F. Tracy, referee in Levy vs. the Board of estimate and apportionment; submitted by Bureau of municipal research ... New York, I909. 3 p. I., 3-83 p. fold. tables. School progress and school facts ... [New York], 1909. 73 p. Contents.

Foreword: Trustees, Bureau of municipal research.-School reports as they are: a rejoinder: John L. Tildsley, principal De Witt Clinton high school, New York city, answered point for point from official records by Mr. Allen.-School reports as they are: William H. Allen. [Reprinted from the Educational review, New York, Feb., 1909, written in collaboration with Dr. Elizabeth K. Adams]-Questions answered by school reports as they are: Bureau of municipal research [with special t.-p.].

School stories; illustrated guide to school subjects of interest... New York. I909. 88 p. illus., diagrs.

Contents.

Foreword.-Topical index to school subjects of interest, tenth annual report for New York city schools .... issued by the city superintendent in March, I909, for the school year ending July 31 , I 908 .

Steps taken to locate and to solve problems of enforcing tenement house laws.

["Summary of report by the Bureau of municipal research in New York city's tenement house department, being based upon examinations made in 1908 and 1909 in coöperation with the department."] [New York, I909.] I6 p.

Tenement house administration, steps taken to locate and to solve problems of enforcing the tenement house law. [New York], 1909. I75 p. illus., fold. tab.

What should New York's next comptroller do? "The business issue of the next administration." [New York, I909.] I5 [I] p.

\section{I9IO}

Business methods of New York city's Police department; critical study and constructive suggestions pertaining to administrative and accounting methods of the Bureau of repairs and supplies .. [New York], 1910. 212 p. fold. tables, fold. diagrs.

"Based upon inquiry requested by Police commissioner Bingham, July, 1908, and pursued from August, 1908, to April, I9c9, with the coöperation of William $F$. Baker, now police commissioner and then first deputy."

Municipal reform through revision of business methods, New York city. [New York], I9ı. $5^{8}$ p. 


\section{EFFORTS FOR ADMINISTRATIVE REFORM}

Resolutions providing for inquiries into education, health, hospital and charitable activities of the city of New York and for standardizing salaries and service requirements among city employees. New York, I9IO. II p.

St. Louis, a preliminary survey of certain departments of the government of the city of St. Louis, with constructive suggestions for changes in organization and method. St. Louis, City council I9I0. 416 p. plans, forms, diagrs.

"The Bureau of municipal research undertook to make a preliminary survey of the government of St. Louis at the request of the Executive committee of the municipal voters' league."-Introduction.

IgI I

Does your accounting system give you all the information you need? May, I9I I. I6 p.

A report on the Division of child hygiene, Department of health, with constructive suggestions. Prepared for the committee of the Board of estimate and apportionment on health, hospitals and charities inquiries, by the Bureau of municipal research, New York city. [New York], igII. 75 p. incl. forms (2 fold).

\section{I9I 2}

Report of survey of the Department of health and the Department of education, city of Atlanta, Georgia, made for the Atlanta chamber of commerce committee on municipal research. By S. G. Lindholm for the New York bureau of municipal research. December, I9I2. 44 p. fold. tab., diagrs.

Each report has special t.-p.

Six years of municipal research for New York city; record for I906-I9II. [New York] [1912]. 80 p.

I9I3

Administrative methods of the city government of Los Angeles, California. Report of a preliminary survey of certain city departments made for the Municipal league of Los Angeles ... Los Angeles, Municipal league of Los Angeles, I9I3. 27 p.

Efficiency and next needs of St. Paul's health department, report submitted by the New York bureau of municipal research and Training school for public service, March, 19I3. [New York, I9I3]. $48 \mathrm{p}$.

At head of title: St. Paul anti-tuberculosis committee, St. Paul, Minnesota.

Organization and administration of the city government of Atlanta, Ga. (Exclusive of Health and Educational departments.) Report of a general survey made for the Atlanta chamber of commerce committee on municipal research, by Herbert R. Sands, for the New York bureau of municipal research, November, I9I2. Atlanta, Ga., Appeal pub. co. [19I3?] 64 p.

Organization and administration of the city government of Springfield, Massachusetts. Report of a survey made by the New 


\section{AGENCIES FOR MUNICIPAL ADMINISTRATION}

York Bureau of municipal research, Jan., I9I3. New York, I9I3. $93 \mathrm{p}$.

Organization and business methods of the city government of Portland, Oregon, report by Bureau of municipal research, New York city. [New York? I9I3.] II9 p.

Reports on various subjects relating to the Police department. (In New York (City) Board of aldermen. Special committee to investigate the Police dept. Stenographer minutes [hearings of Sept. 9, I9I2, to March 27, 1913], etc. I9I3. v. 6, p. 4445482 I).

\section{I9I4}

City and county of Denver; report on a survey of certain departments ... prepared for the Colorado taxpayers protective league. [Denver, The Great western printing and publishing co., printers, I9I4?] 583 p. plates, fold. plan, fold. diagrs.

Next steps in the development of a budget procedure for the city of New York. [New York, 'I9I4.] I32 p. incl. tables, forms.

A report on the police pension fund of the city of New York, submitted to the Aldermanic committee on police investigation by the Bureau of Municipal research ... [New York, I9I4.] 212 p. incl. tables, charts.

\section{I9I 5}

Business and accounting methods, Indian bureau. Report to the Joint commission of the Congress of the United States, Sixtythird Congress, third session, to investigate Indian affairs, relative to business and accounting methods employed in the administration of the Office of Indian affairs. Prepared by the Bureau of municipal research, New York. Washington, Govt. print. off., I915. 86 p.

Government of Monroe County, N. Y. (including town government), description of organization and functions, transmitted to the New York state constitutional convention by the New York state constitutional convention commission, prepared for the Rochester bureau of municipal research. [Albany, J. B. Lyon company, printers, 1915.] 60 p. fold. diagrs. (In New York state constitutional convention commission. City and county government. [No. 3.] Albany, I9I5.)

Government of Nassau County, N. Y., description of organization and functions. Transmitted to the New York state constitutional convention by the New York state constitutional convention commission. Prepared for the Commission on the government of Nassau County. [Albany, J. B. Lyon company, printers, I9I5.] Io8 p. fold. diagrs.

(In New York state constitutional convention commission "City and county government." [No. 4.] Albany, 19I5.)

Includes a report on the government of Nassau County, the towns of Hempstead, North Hempstead and Oyster Bay, and the village of Hempstead.

Government of the city of Rochester, N. Y., description of organization and functions transmitted to the New York state constitu- 


\section{EFFORTS FOR ADMINISTRATIVE REFORM}

tional convention by the New York state constitutional convention commission, prepared for the Rochester bureau of municipal research. Albany, J. B. Lyon company, printers, 1915. 104 p. fold. diagrs.

(In New York state constitutional convention commission. City and county government. [No. 2.] Albany, 1915.)

Government of the city of Rochester, N. Y. General survey, critical appraisal and constructive suggestions, prepared for the Rochester bureau of municipal research. [Rochester? I9I5?] $546 \mathrm{p}$. plates, plan, fold. tab., diagrs.

Preliminary report outlining a proposed reorganization of the state government submitted as a basis of discussion to the "Committee on the Governor and other state officers," New York State constitutional convention ... New York, 1915. 23 p.

Reading, Pennsylvania. Report on a survey of the municipal departments and the school district. Prepared for the Chamber of commerce of Reading. [Reading, Pa., Weiler's printing house, I9I5?] 368 p. diagrs.

\section{6}

Hall of records power plant. Report and discussion of physical test and costs of operation and maintenance. Test conducted for a full year, I9I3, under the auspices of a board of engineers composed of representatives of the city of New York, the New York Edison company and the New York Bureau of municipal research. New York, I916. x, 673 p. plates, plans (part. fold.), tables (part. fold.), diagrs. (part. fold.), forms.

Memorial to the Senate and Assembly by the Bureau of municipal research, asking consideration in Committee of the whole of the Appropriation bill submitted by the governor with his annual message, January 5, 1916. Transmitted to the Legislature January 25, I916. Albany, J. B. Lyons company, printers, I9I6. 40 p.

Report on a survey of the government of the city and county of San Francisco. Prepared for the San Francisco Real estate board by the Bureau of municipal research, New York, 1916. San Francisco, Rincon publishing company, printers [I9I6]. xxvi, 68I p. front., fold. charts, fold. tables, forms ( 1 fold.).

Torrens registration system in New York: memorandum relative to proposed amendments to the real property law governing registation of real property titles known as the Torrens law. Prepared by the Bureau of municipal research, New York, February, I9I6, with letter of transmission to the Board of estimate and apportionment of the city of New York by John J. Hopper, register of the county of New York. [New York, I916.] 29 p.

\section{7}

The citizen and the government. New York, 1917. 20 p.

Columbus, Ohio; report on a survey of the city government. Columbus, O., The Stoneman press [1917]. 257 p. diagrs.

A general administrative survey of the city of Jamestown, New York; a study of the methods in use in the various departments of the city, together wth recommendations for improvement based 


\section{AGENCIES FOR MUNICIPAL ADMINISTRATION}

upon long study and wide experience. Prepared for the Jamestown Board of commerce. [Jamestown, N. Y., Journal press, inc., printers, 1917.] 42I, ii p. incl. diagrs., forms.

Cover title: Government of the city of Jamestown, New York, general municipal survey and constructive recommendations.

Report on a survey of the city government of Indianapolis, Indiana. Prepared for the Indianapolis chamber of commerce. Indianapolis, Wm. B. Burford, printer [1917]. x, 568 p. illus., fold. charts.

Summary of recommendations from report of a survey of the city government of Richmond, Va. New York, 1917. 80 p.

Ten years of municipal research ... [New York, I9I7?] 22 p. fold. chart.

\section{PERIODICALS}

Efficient citizenship. (weekly and semi-weekly bulletins) New York (about 655 issued to date).

Municipal research, to promote the application of scientific principles to government. Issued . . by the Bureau of municipal research. No. I-July, I9I3. New York [1913.]

Contents. (Subheadings are listed only where of special significance.)

No. I-56, July I3-Dec., I9I4 (leaflets).

No. 57, Jan., I915. Announcement [of the first issue of Municipal research as a monthly].

The citizen and the government-a statement of policy and method. p. I-4.

Next step in the development of a budget procedure for the city of Greater New York. (A report.) p.

No. 58, Feb., 1915. "A $\mathrm{A}^{5-\mathrm{I} 42 .}$ state budget"-constructive proposals to be submitted to the State constitutional convention, by Frederick A. Cleveland. p. 147-68.

The practical side of budget procedure, by Charles D. Norton. p. 169-72.

No. 59, Mar., 1915. Financial problems of the city of New York, p. 199-210.

New York City's need for a financial program, p. 2II-39.

The "pay-as-you-go" agreement. p. 24052.

No. 60, April, 1915. The condition of the New York State sinking funds. p. 273-308.

No. 6r, May, 19I5. The constitution and government of the state of New York. 246 p.

No. 62, June, 1915. Budget systems, a discussion before the New York Constitutional convention. $447 \mathrm{p}$.

Administration and financial methods, by Dr. Frank J. Goodnow. 
Financial administration with special reference to English experience, by Dr. A. Lawrence Lowell.

No. 63, July, I915. State administration; discussions of proposed amendments for the reorganization of the executive branch before the New York Constitutional convention. $630 \mathrm{p}$.

The federal government as an example, by Hon. W. H. Taft.

State government from the point of view of administrative law, by $\mathrm{Dr}$. Frank J. Goodnow.

No. 64, Aug., 1912. State finances; a report on the financial procedure of the state of New York, with special reference to the direct tax, I9II-I9I6. I9 p.

[Extra No. I, Aug., 1915.] Annual report of the Training school for public service, conducted by the Bureau of municipal research, I9I4-I9I5. $30 \mathrm{p}$.

No. 65, Sept., 1915. Administration of the Indian Office. II7 p.

Supplement: Public opinion and national economy, by Mr. R. Fulton Cutting.

No. 66, Oct., 1915. Legal rights of civil servants in the city of New York [by George H. Stover]. 202 p.

No. 67, Nov., 1915. Standardization of public employments. Prepared under supervision of Arthur W. Procter. Pt. I. An interpretation of the standardization movement. II7 p.

No. 68, Dec., 1915. Training for municipal service. $5 \mathrm{I}$ p. tables (part. fold.).

The problem of training for the public service, by Charles A. Beard.

Report of the Committee of the College of the city of New York on Municipal service survey, by Frederick E. Breithut.

No. 69, Jan., 1916. Responsible government. I35 p.

The budget idea in the United States.

Memorial to the Legislature of the state of New York, recommending amendment of law, to provide for budget procedure, and correspondence with the Governor.

No. 70, Feb., I9I6. Budget legislation in two states. I02 p.

Part I-Financial legislation in New Jersey. 


\section{AGENCIES FOR MUNICIPAL ADMINISTRATION}

Part II-Financial legislation in New York.

No. 7i, Mar., I9I6. A national program to improve methods of government. $88 \mathrm{p}$. plates.

No. 72, April, 1916. The history of appropriations in the legislative session of 1916, New York State [by Birl E. Schultz]. I34 p.

No. 73, May, I9I6. Three proposed constitutional amendments for control of the purse. $86 \mathrm{p}$.

The Maryland proposed constitutional amendment for an executive budget.

The New York proposed constitutional amendments.

No. 74, June, I9I6. The accounting and reporting methods of the state of New York [by Fred F. Blachly]. 212 p.

No. 75, July, I9I6. The purposes of the indebtedness of American cities, I880-I9I2 [by Fred Emèrson Clark]. 72 p.

No. 76, Aug., I916. Standardization of public employments. Part II. The practical side of standardization in American governments, prepared under the supervision of Arthur W. Procter. I48 p. (Contains sections on standardization in Chicago, Pittsburgh, New York City, and New York State.) (Part I was published in the November, 1915, issue, No. 67 of Municipal research.)

No. 77, Sept., 1916. Citizen agencies for research in government. Part I. II 4 p.

The organization and work of the $\mathrm{Fi}$ nance commission of the city of Boston.

.The bureau in Philadelphia, the first municipal venture outside New York.

The Chicago bureau of public efficiency.

The Dayton bureau of research.

The Ohio institute for public efficiency.

The Milwaukee Citizens bureau of municipal efficiency.

The Bureau of municipal research of the Minneapolis civic and commerce association.

The Akron bureau of municipal research.

The Bureau of state research of the New Jersey state chamber of commerce.

No. 78, Oct., I9I6. The engineer in public service, by Frederick E. Breithut. Part I. 7I p.

The engineer in the service of the United States government.

No. 79, Nov., 19ı6. The engineer in public service, by Frederick E. Breithut. Part II. I76 p. 


\section{EFFORTS FOR ADMINISTRATIVE REFORM}

The engineer in the service of New York state.

The engineer in the service of New York city.

List of official registers and directories, published by the United States government.

List of civil service commissions in the United States.

No. 80, Dec., I9I6. The elements of state budget making. $63 \mathrm{p}$.

"Maryland's executive budget," by Governor Harrington of Maryland.

No. 8I, Jan., I9I7. Some results and limitations of central financial control as shown by nine years' experience in New York city. $63 \mathrm{p}$.

No. 82, Feb., 19I7. Highway laws of the United States, a topical discussion, by A. N. Johnson. I63 p.

No. 83, Mar., I9I7. Japanese administration and finance. 72

No. 84, April, I9I7. Problems of highway administration [by William A. Bassett]. 269 p.

No. 85, May, I9I7. Widows' pension legislation [by Chester Jacob Teller]. I25 p.

A year of widows' pensions in New York state.

No. 86, June, I9I7. The New York state legislative budget for I9I7 [by John L. Keddy and Charles F. Kerrigan]. I 40 p.

No. 87, July, I9I7. Canadian provincial budget system and financial history, by Harold G. Villard. $60 \mathrm{p}$.

No. 88, Aug., I9I7. The New York city budget [by Arnold W. Lahee]. I $54 \mathrm{p}$.

No. 89, Sept., 1917. Instruction in civics in New York city high schools; a statistical survey. 39 p.

No. 90, Oct., 1917. The state movement for efficiency and economy [by Raymond Malley]. I63 p.

\section{Coöp'erative Investigations}

The Bureau of municipal research assisted in the preparation of the following reports:

A bureau of child hygiene; coöperative studies and experiments by the Department of health of the city of New York and the Bureau of municipal research ... [New York] Bureau of municipal research, I908. 40 p., I l. incl. tables. front., plates, forms.

The constitution and government of the state of New York: an 


\section{AGENCIES FOR MUNICIPAL ADMINISTRATION}

appraisal. Transmitted to the New York state constitutional convention commission. [Prepared for the Constitutional convention commission by the Bureau of municipal research and the New York state department of efficiency and economy.] [Albany] Bureau of municipal research, 19I5. 250 p. incl. diagrs.

Efficiency and next needs of St. Paul's health department, report submitted by the New York bureau of municipal research and Training school for public service, March, I9I3. [New York, I9r3.] $48 \mathrm{p}$.

At head of title: St. Paul anti-tuberculosis committee, St. Paul, Minnesota.

Government of the city of New York; a survey of its organization and functions, prepared for the Constitutional convention, I9I5, by the office of the commissioners of accounts, New York city, and New York Bureau of municipal research. New York, J. J. Little \& Ives company, I9I5. xxxi, I343 p.

Government of the state of New York. A description of its organization and functions. Prepared for the New York State constitutional convention commissiont by the New York State department of efficiency and economy and New York Bureau of municipal research. January I, I915... A Albany, J. B. Lyon company, printers, I9I5.] xxxii, 768 p. diagrs. (part fold.).

Municipal year book of the city of New York. [New York], I9I3.

\section{PUBLICATIONS OF THE METZ FUND}

Publication No. I-New York, I9I I-

Contents.

No. 4. To Mayors, comptrollers and auditors. IgII.

No. I4. Would a budget exhibit help your city? I9II.

No. I9. Unit costs in municipal reports. I9II.

No. 35. Plan for establishing a model government in the District of Columbia.

No. - Short talks on municipal accounting and reporting. National fund for promoting efficient municipal accounting and reporting. I9II.

Handbook of municipal accounting, prepared by the Metz fund from descriptive and critical data collected, and constructive recommendations made by the Bureau of municipal research. New York, D. Appleton and company, I9I3. xxx, 318 p. fold. forms, fold. tables. (Half-title: Metz fund handbooks of city business methods ...)

PUBLICATIONS OF TRAINING SCHOOL FOR PUBLIC SERVICE

Training school for public service; announcement-I9II, conducted by the Bureau of municipal research ... [New York, I9II.] I6 p.

The same, I9r6-I9I7. I2 p.

Preliminary report on conditions and needs of rural schools in Wisconsin. Results of field study reported to the Wisconsin state board of public affairs by the Training school for public service. 


\section{EFFORTS FOR ADMINISTRATIVE REFORM}

August, I912. [New York, I912.] 92 p. (Efficient citizenship bulletin, No. 587.)

[First] annual report. I9II-I9I2.

[Second] annual report for I9I2-I9I3. (Efficient citizenship bulletin, No. 670.)

[Third] annual report for I9I3-I9I4.

[Fourth] annual report for I9I4-19I5. 30 p. (Municipal research [No. 64]. Extra No. I, August, 1915.)

\section{ARTICLES}

Allen, W. H. Better-business methods for cities. American Review of Reviezws, Feb., 1908. v. 37: 195-200.

Allen, William $H$. Training men and women for public service. American academy of political and social science. Annals, May, I9I2. v. $4 \mathrm{I}: 307-\mathrm{I} 2$.

[The National training school for public service conducted by the New York Bureau of municipal research.]

Beard, C. A. Reconstructing state government. New Republic, Aug. 2I, I9I5. v. 4: sup. I-I6.

[Deals largely with the Bureau of municipal research and its work in connection with the New York state constitutional convention.]

Bruère, Henry. Bureau of municipal research. What it has done for better government in New York city. World's Work, April, I9I2. v. $23: 683-6$.

Bruère, Henry. Government and publicity. Independent, Dec. I2, 1907. v. 63: 1422-6.

Cleveland, Frederick A. An agency of citizen inquiry. (In his Chapters on municipal administration and accounting.) New York, I909. p. 346-6i.

Heaton, J. P. Municipal research; ten years of the pioneer New York bureau. Survey, Dec. 4, 1915. v. 35:230.

Hopkins, George B. New Yórk bureau of municipal research. American academy of political and social science. Annals, May, I9I2. v. $4 \mathrm{I}: 235-44$.

[Accomplishments of the Bureau.]

Prendergast, William A. The work of the Bureau of municipal research in relation to the administration of the city's finances. I9I5. 8 p.

Reprinted from the Real Estate Magazine, November, 1915.

Report of the division of field work of the New York bureau of municipal research for the year ended Dec. 31, 1916. Record and Guide, Feb. 7, 1917. v. 99: 218.

Wickersham, George W. The new constitution and the work of the Bureau of municipal research. 19I5. 6 p.

Reprinted from the Real Estate Magazine, October, 1915. 


\section{CHAPTER VII}

AGENCIES FOR INVESTIGATING THE ADMINISTRATION OF PARTICULAR CITIES: OFFICIAL

There are but few instances where an official body has been created by a municipality for the purpose of making a study of its system of administration with a view to effecting improvements in it. The explanation of the slight extent to which efforts to improve methods of municipal administration of this character have been made is probably to be found in the difficulty that is experienced in giving to such bodies and their work a non-political character and the extent to which this field has been occupied by privately organized and supported bureaus of municipal research.

Boston, Mass.: Finance Commission of 1907-1909. In response to a public demand, voiced especially by the Good Government Association, for an investigation of the financial condition and fiscal administrative methods of the city, the mayor of Boston, in January, 1907, sent a message to the city council in which he recommended the appointment of a finance commission empowered and directed to make this investigation. The council complied with this request, and authorized the mayor to appoint a commission which should include one representative from each of the following organizations: The Associated Board of Trade, Chamber of Commerce, Boston Merchants' Association, Clearing House Committee, Real Estate Exchange and Central Labor Union. The following functions and powers were given to this body:

Such finance commission shall examine into all matters pertaining to the finances of the city, including debt, taxation and expenditures, shall give public hearings, and shall in particular inquire: 


\section{EFFORTS FOR ADMINISTRATIVE REFORM}

I. Whether under the present practice of the city its objects of expenditure are rightly divided between those which may properly be provided for by loan and those which should be met by taxation, and whether its loans are now issued for proper periods.

2. Whether the present distinctions between loans inside and outside the debt limit are based upon sound financial principles.

3. Whether any change should be made in the present system of accumulating sinking funds and issuing new loans annually.

4. Whether debt, taxation or assessments upon property are now excessive, and, if so, in what manner the same can be reduced.

5. Whether present systems of bookkeeping, auditing and administration afford sufficient protection to the city treasury.

6. Whether the cost of any municipal works or services now paid for from the city treasury should be raised by special assessment, or whether any changes should be made in existing provisions for the laying and collecting of special assessments.

7. Whether the financial burden imposed upon the city in connection with the expenditures for the construction and maintenance of metropolitan works is excessive or unfair, and, if so, how the same can be reduced or made equitable.

8. Whether any changes should be made in the present distribution of powers relative to appropriations, loans and expenditures.

9. Whether the general taxation laws of the state, and particularly those relating to the taxation of the property of corporations, operate fairly in respect to the interests of Boston, and, if not, what changes should be made in them.

Io. Whether appropriations and loans for the several departments of the city are larger than necessary.

I I. Whether the limit of municipal indebtedness should be fixed by constitutional amendment, or the present statute, fixing the limit, should be repealed or amended.

It was further ordered that the Finance Commission inquire-

I. Whether it is advisable to create new sources of revenue, and, if so, to suggest the sources and for what purpose the proceeds should be applied. 
2. To inquire into the present general plan of sewer construction and report whether or not it is the one best adapted to the city; and, if not, to investigate and report a comprehensive scheme for future development of the sewer system, with special reference as to the amount of money the city can annually afford to spend for the completion of work already begun.

Fifty thousand dollars was appropriated for the expenses of the commission.

To facilitate the work of the commission, the legislature, on petition, granted the commission the power to compel the attendance of witnesses, the production of books and papers, and to administer oaths. ${ }^{1}$

The commission organized, itself for active work on July 30, 1907, and from that date until January 29, 1909, when the final report was issued, interim reports were made on the investigations which were being conducted. Technical experts were employed as needed and their findings were published by the commission. The final report stated the conclusions reached and contained an account of the changes recommended by the commission as to administration and as to the fundamental structure of the city government.

The legislative measures which the commission regarded as essential to enable the people of Boston to redeem their government were summarized as follows:

I. A simplified ballot, with as few names thereon as possible.

2. The abolition of party nominations.

3. A city council consisting of a single small body elected at large.

4. The concentration of executive power and responsibility in the mayor.

5. The administration of the departments by trained experts, or persons with special qualifications for the office.

6. Full publicity secured through a permanent finance commission.

${ }^{2}$ The paragraphs which follow are from the report of the chairman of the commission, Hon. John R. Murphy, as published in Municipal Research, No. 77 (Sept., 1916). 


\section{EFFORTS FOR ADMINISTRATIVE REFORM}

The commission closed its report with these words:

These measures will enable a good mayor and city council to give the citizens a really good administration, will encourage indifferent men to keep a fairly straight course by freeing them from the partisan fetters of the present system, and will deter bad men, if elected, from demoralizing the public service and using the public money for their own advantage.

The task set before the commission was to devise a practical working form of government for the city of Boston; not a charter for some other city; much less a charter good for all cities. It is under no illusion that the changes recommended will of and by themselves secure good government. No municipal charter can be a self-executing instrument of righteousness. If the people want the kind of government they have had during the past few years, no charter revision will prevent it. If, as the commission believes, they desire good government, the plan suggested should enable them to obtain and keep it.

Appended thereto was a draft for a new city charter; one of the provisions of this proposed charter was the establishment of a permanent finance commission, which, in order that it might be independent of city politics, should be appointed by the Governor.

Four volumes of reports were published by the commission. These are listed as the first items in the joint list of publications of the commission and of the permanent commission which succeeded it, given after the account of the latter body immediately following.

Boston, Mass.: Permanent Finance Commission. ${ }^{1}$ In 1909, a bill was passed by the Senate and House of Representatives relating "to the administration of the city of Boston and to amend the charter of the said city," and became chapter 486 of the acts of I909. This bill was substantially the new charter proposed by the Finance Commission, although a number of minor changes were made. The sections relating

${ }^{1}$ This account is taken from the report of the chairman of the commission, Hon. John R. Murphy, as published in Municipal Research, No. 77 (Sept., I916). 
to the appointment of the Finance Commission were as follows:

Within sixty days after the passage of this act, the governor with the advice and consent of the council shall appoint a finance commission to consist of five persons, inhabitants of and qualified voters in the city of Boston, who shall have been such for at least three years prior to the date of their appointment, one for the term of five years, one for four years, one for three years, one for two years, and one for one year, and thereafter as the terms of office expire in each year one member for a term of five years. Vacancies in the commission shall be filled for the unexpired term by the governor with the advice and consent of the council. The members of said commission may be removed by the governor with the advice and consent of the council for such cause as he shall deem sufficient. The chairman shall be designated by the governor. His annual salary shall be five thousand dollars, which shall be paid in monthly instalments by the city of Boston. The other members shall serve without pay.

It shall be the duty of the Finance Commission from time to time to investigate any and all matters relating to appropriations, loans, expenditures, accounts, and methods of administration affecting the city of Boston or the County of Suffolk, or any department thereof, that may appear to the commission to require investigation, and to report thereon from time to time to the mayor, the city council, the governor or the general court. The commission shall make an annual report in January of each year to the general court.

Whenever any pay roll, bill, or other claim against the city is presented to the mayor, city auditor, or the city treasurer, he shall, if the same seems to him to be of doubtful validity, excessive in amount, or otherwise contrary to the city's interest, refer it to the finance commission, which shall immediately investigate the facts and report thereon; and pending said report payment shall be withheld.

The said commission is authorized to employ such experts, counsel and other assistants, and to incur such other expenses as it may deem necessary, and the same shall be paid by said city upon requisition by the commission, not exceeding in the aggregate in any year the sum of twenty-five thousand dollars, or such additional sums as may be appropriated for the purpose by the city council and approved by the 
mayor. A sum sufficient to cover the salary of the chairman of the commission and the further'sum of at least twenty-five thousand dollars to meet the expenses as aforesaid shall be appropriated each year by said city. The commission shall have the same right to incur expenses in anticipation of its appropriation as if it were a regular department of said city.

For the purpose of enabling the said commission to perform the duties and carry out the objects herein contemplated, and to enable the mayor, the city council, the governor, or the general court to receive the reports and findings of said commission as a basis for such laws, ordinances or administrative orders as may be deemed meet, the commission shall have all the powers and duties enumerated in Chapter 562 of the acts of the year I9O 8 and therein conferred upon the commission designated in said act; but counsel for any witness at any public hearing may ask him any pertinent question and may offer pertinent evidence through other witnesses subject to cross-examination by the commission and its counsel.

The new commission authorized by the above act, organized itself on June 24, I909, and prepared to continue the work of its predecessor. It was realized, however, that the new commission would not be obliged to investigate past methods and practices; its duties would consist chiefly of keeping current watch over the administration of the city's business.

Since I909 the work of the commission has divided itself into three classes:

I. Reports to the Governor, to the General Court and to the committees thereof on legislative bills affecting the financial interests of Boston.

2. Constructive reports to the mayor, city council, and the school committee recommending economical improvements in the departments of the city so as to reduce the administrative cost thereof.

3. Critical reports to the city government on particular acts of maladministration in various municipal departments.

The scope of the work of the commission is so broad and the lines of studies so varied that to give an exact description of them would involve a list of the reports which have ap- 


\section{AGENCIES OF PARTICULAR CITIES: OFFICIAL}

peared in its annual volumes from I9IO. It is sufficient commentary on the work of the commission to state that the net debt of the city has actually decreased in the last eight years and the borrowing of money outside of the debt limit has practically ceased. Furthermore, the old and ancient custom of an annual "pork barrel" loan bill has passed away and not once has an attempt been made to revive it.

Among some of the large achievements of the commission are its report on the survey made on the Boston school system in I9I I and the report recommending the adoption by the city of Boston of the segregated budget system. The latter system was adopted in 1918 and has thus far demonstrated its usefulness for the city.

The school department has coöperated cordially in the commission's investigation of its departments and recently a new survey has been made of the school system, the results of which will shortly be published by the commission.

The annual appropriation of the commission amounts to approximately $\$ 30,000$ and the commission has on its staff a permanent force of eight employees.

\section{PUBLICATIONS}

The Finance Commission of the city of Boston. Appointments, organization and communications. [Reports] vol. I. Boston, Municipal printing office, I908. $560 \mathrm{p}$.

Reports and communications. vol. II. Boston, I909. 304 p.

Contents.

Test run of the Chestnut Hill stone crusher.

Municipal printing plant.

System of publishing city documents and the necessity of establishing a new statistics department.

History of the city waterworks and the management of the Water department.

Health department [and] report of the special committee.

New city hall.

Sanitary department [and] report of Mr. X. Henry Goodnough.

Sinking funds.

City debt.

Final report of the Finance commission [on the condition of the city government], Jan. 29, I909, p. I75-258.

[Reports] vol. III. Reports of Metcalf \& Eddy, consulting civil engineers, upon the Water department, the Sewer division of the Street department, and miscellaneous matters. Boston, I909. I226 p. tables (part. fold.), diagrs. (part. fold.). 


\section{EFFORTS FOR ADMINISTRATIVE REFORM}

[Reports] vol. IV. Report of Samuel Whinery, consulting civil engineer, upon the Street department. Boston, 1909. 333 p. tables. (part. fold.).

Appointments, organization and communications. [Reports] vol. V. Boston, 1910. I43 p.

[This is the first volume of the new Finance commission, appointed June 23, 1909. "It has been numbered five, so as to present all the reports of both commissions in a single continuous series."]

Contents.

Report to the General court, p. 5-42.

Official communications to the city government, p. 43-94. (Contains sections on political activity of city employees and on penal institutions department.)

Summary of specific recommendations made by the former Finance commission with a record of the action taken thereon, p. 95-1 39 .

Reports and communications. vol. VI. Boston, I9II. 252 p.

Partial Contents.

Increase in city's pay roll and decrease in efficiency of day labor force.

Soldier's relief department.

Elementary school accommodations.

Contract for gas lighting.

Street lighting situation.

Influence of politics in appointments.

Department of public works.

Taxing unearned increment of land.

Cost of water bridges.

Proposed consolidation of the bath, music, public grounds and park departments.

Abolition of the Registry department.

Rejection of the civil pension act.

Reports and communications. vol. VII. Boston, 1912. 320, $256 \mathrm{p}$.

Partial Contents.

Children's institutions department.

Consumptive's hospital department.

Indebtedness of the city of Boston.

Protection against fire.

Lighting the streets with gas.

Bids for supplying coal to the city of Boston.

Licenses for private uses of the public streets.

High pressure water service.

Pensions in the Fire department.

Cost of minor's licenses.

General pension act for city employees and laborers.

Central power and heating plant.

Contract for disposal of city refuse.

Land court.

Report of the Boston school system. Boston, I9II. $256 \mathrm{p}$.

Reports and communications. vol. VIII. Boston, I9I3. $205 \mathrm{p}$.

Contents.

Appointments to the Collecting department. 


\section{AGENCIES OF PARTICULAR CITIES: OFFICIAL}

Collection of money on bail bonds, etc.

Administration of the Bath department.

The Ferry service.

Street lighting situation.

Automobile apparatus for the fire department.

A municipal garage.

Building department.

Payments for overtime.

Reports and communications. vol. IX. Boston, I9I4. 240 p.

Partial Contents.

Licenses for stands for sight-seeing automobiles.

Pensioning of veterans who had ceased to be employees of the city.

Participation by members of the City council in the executive and administrative business of the city.

Reforms in the Ferry division by the Public works department. Reports and communications. vol. X. Boston, I9I5. 294 p.

Contents.

Vacations for city laborers.

Concession privileges.

Standardization of salaries of city and county employees.

Purchase of clothing for city employees.

Payments for overtime.

System of purchasing supplies in Boston.

Automatic lighting devices for street lamps.

Reports and communications. vol. XI. Boston, I9i6. 394 p.

Contents.

Reorganization of the Health department.

The city budget.

Increase in the tax limit of Boston.

Condition of streets in Boston.

High pressure water service installation.

Street construction in Boston.

Cost of city passenger automobiles.

Adoption of check paying system for city employees.

Reports and communications. vol. XII. Boston, I9I7. 486 p.

Contents.

Floor preservatives.

Granting one day off in three to firemen.

Segregated budget.

Payment of city employees by check.

The Boston school department, p. I59-222.

Letter to the Boston Finance commission from James H. Van Sickle, chairman of the Survey committee [presenting a report of a study of certain phases of the public school system of Boston, made under the auspices of the Boston Finance commission], p. 223-443.

[Published also as Document 87-1916, in a volume of 219 pages.]

The reorganization of the administration of schools.

Reorganization of District supervision.

The High School situation.

Special departments. 


\section{EFFORTS FOR ADMINISTRATIVE REFORM}

Vocational education.

Vocational needs of Boston children.

Expenditures for school purposes in Boston compared with expenditures in other large American cities.

Construction of school buildings.

Annual reports, I9I0-date (Public Doc. No. 88). [First annual report is for the period ending Jan. 3I, I9I0.]

\section{Chicago, Ill.: Commission on City Expenditures. In 1909} provision was made by the city government of Chicago for a special commission to make a thorough study of city expenditures with a view to making recommendations looking to the more economic and efficient expenditure of the city's money. This commission was duly appointed August I9, I909, and was popularly known as the "Merriam Commission" after its chairman, Professor C. E. Merriam, of the University of Chicago.

This commission proved to be a very energetic body. During the balance of the year 1909 and I9Io it made an investigation of the expenditures of nearly all the city departments, the results of which were embodied in twenty-one reports. Seventeen of these reports were at once published in pamphlet form. The remaining four reports were subsequently published by the Chicago Bureau of Public Efficiency. In April, I9II, the commission was deemed to have been abolished as a result of the change which then took place in the city administration. The work of the commission, however, was continued by the Efficiency Division of the Chicago Civil Service Commission and the Chicago Bureau of Public Efficiency, both of which organizations owed their creation directly to the impetus given to the work of governmental research by that commission.

\section{PUBLICATIONS}

Preliminary report ... on the purchase of castings from the Cummings foundry company by the business agent on requisitions from the Department of public works, I907-1909. Chicago, I9Io. I9 $\mathrm{p}$.

Preliminary report on Southwest land and lake tunnel system. I9IO. 43 p.

Preliminary report on street paving. I9I0. $34 \mathrm{p}$.

Preliminary report on the building department. I9I0. $23 \mathrm{p}$.

Preliminary report on the Business agent's office of the city of Chicago. I9I0. I6 p. 


\section{AGENCIES OF PARTICULAR CITIES: OFFICIAL}

Preliminary report on the Department of electricity. I9I0. $40 \mathrm{p}$. Preliminary report on the Division of bridges and harbors. Dept. of public works. 1910. $32 \mathrm{p}$.

Preliminary report on the House of correction. 1910. $40 \mathrm{p}$.

Preliminary report on the McGovern street repair contract of 1908 . 1910. 3I p.

Preliminary report on the Police department. I9IO. $18 \mathrm{p.}$

Preliminary reports on purchase of lumber, budget making, Lawrence avenue sewer, Bureau of sewers, City clerk's office, purchase of coal. I9Io. $90 \mathrm{p}$.

Preliminary report on the Fire department. I9IO. 53 p.

The water works systems of the city of Chicago. Report of Dabney H. Maury to the Chicago Commission on city expenditures. Pub. by the Chicago bureau of public efficiency. Dec., IgII. 52 p. fold. tables.

Bureau of streets of the city of Chicago. Report of Richard T. Fox to the Chicago Commission on city expenditures. Pub. by Chicago bureau of public efficiency. Dec., I9II. p. 7-36.

The Civil service commission of the city of Chicago. Report of Russell Whitman [and others] to the Chicago Commission on city expenditures. (In its Bureau of streets, etc. Pub. by Chicago bureau of public efficiency, Dec., I9II. p. 37-78.)

Special assessment accounting system of the city of Chicago. Report of T. W. Betak to the Chicago Commission on city expenditures. (In its Bureau of streets, etc. Pub. by Chicago bureau of public efficiency, Dec., I9II. p. 79-II2.)

\section{Chicago, Ill.: Efficiency Division of the Civil Service} Commission. The Civil Service Commission of Chicago at the time of the creation of the Commission on City Expenditures, an account of which has just been given, had established an enviable record for public-spirited and energetic action for municipal reform. In I909, as the result of the disclosure of conditions in the city government by that commission, provision was made by the city council for the creation of a permanent efficiency division that should be a part of the organization of the Civil Service Commission. This division was organized under the direction of Mr. J. L. Jacobs. In the neighborhood of $\$ 30,000$ a year was appropriated for a number of years for the support of this division. Under the energetic and capable direction of Mr. Jacobs a large amount of research work of the highest order was done. Regarding this work a writer in the National Municipal Review had the following to say $:^{1}$

${ }^{1}$ National Municipal Review, Vol. IV, No. 14. Oct., I915, p. 662. 


\section{EFFORTS FOR ADMINISTRATIVE REFORM}

The permanent staff of experts and investigators which were recruited from the civil service eligible registers has, at the request of the council, the finance and other committees thereof, and of department heads, investigated and reported on the organization activities and methods of practically every department of the city government.

During this period, in coöperation with the council and the department heads, civil service administration has been raised to a high business standard, conditions of employment improved, both as to service rendered and opportunities of employees, and various measures adopted look toward effective and responsible government administration.

In such inquiries it was found that the information thus obtained, beyond the specific result in view, has been vital, first, to the finance committee and the council in determining judicious apportionment of the $\$ 40,000,000$ appropriated each year; second, to the departments and bureaus in securing and maintaining efficient administration; and third, to the civil service commission in the proper selection and control of the service and the promotion and separation of employees. The efficiency division had become an integral part of the municipal government, acting as a coördinating force as between departments and council committees. With a broad and general view of the entire activities of the city administration, it was in a position to aid the different branches of the service in the preparation of estimates and the annual budget, to solving problems of employment, management and methods.

Notwithstanding the general recognition of the value of this work, and of the work of the Civil Service Commission generally, the new administration which came into office in I9I5, adopted the policy of destroying the work of the commission as far as possible. New members were appointed to the commission who were willing to carry out this policy. One of its first acts was the abolition of the Efficiency Division. The reason assigned was "lack of work and funds." This, despite the fact that appropriations in the I9I 5 budget were available, that five investigations were under way, and a request for the beginning of six other surveys had been made by the city council finance committee. The real reasons were undoubtedly of a purely political character. 


\section{AGENCIES OF PARTICULAR CITIES: OFFICIAL}

Later the work of the Efficiency Division was transferred to the committee on finance of the council, which has organized a staff for its performance.

\section{PUBLICATIONS}

Final report of the Municipal efficiency commission, city of ChicagoI909-I9II. [Chicago, I9II ?] 4I p.

Report on the Department of buildings, city of Chicago. Inquiry conducted at request of Mr. Henry Ericsson, commissioner of buildings, December 28, I9II, to May 6, I912. Conditions, methods and systems in use-organization-conclusions and recommendation. [Chicago, Western newspaper union, 19I2.] $59 \mathrm{p}$. charts.

Final report police investigation. Inquiry conducted by authority of His honor, Carter H. Harrison, Mayor, Sept. 5, I9II, to March 7, 1912. Details of vice investigation-departmental analysis-reorganization plan-conclusions and recommendations. [Chicago, Western newspaper union, I9I2.] 54 p. $3 \mathrm{I}$.

Analysis of employment and charts showing departmental organizations and distribution of employees, city of Chicago, March, 1913. Outline report of work of the Efficiency division, Civil service commission, I909-I9I2. [Chicago, Western newspaper union, 1913.] 99 p. incl. charts (part. fold.).

Contents.

Analysis of employment-19r3.

Outline report of work of the Efficiency division.

Departmental organization and distribution charts.

Reports on the Department of electricity, city of Chicago. Inquiries conducted at request of Mr. Ray Palmer, city electrician, May 24 to November 29, I9I2. Conditions, methods and systems in use and organization of the Department of electricity. [Chicago, Barnard and Miller, I913.] 40 p. incl. charts (part fold.).

Contents.

Report on investigation of the organization of the Department of electricity.

Report on investigation of the Interior wiring bureau.

Report on investigation of police powers of employees in electrical department.

Report on investigation of storehouse and yard-construction and maintenance division.

Report on the gas meter testing division.

Report on the investigation of engineer and janitor service, Board of education, city of Chicago. Inquiry conducted at the request of the Board of education, May I, I9I3, to September 5, I9I3. Compensation, conditions, organization, administrative and efficiency control-conclusions and recommendations. [Chicago, I9I3.] 7I p. tables.

Reports on the Bureau of streets, Department of public works, city of Chicago. Investigations conducted at the order of the City council and at the request of the commissioner of public works, April 21, 1913-October 15, I913. Methods, systems, standards 


\section{EFFORTS FOR ADMINISTRATIVE REFORM}

and schedules of service-bases of estimates and appropriationsadministrative questions, organization of the Bureau of streets and of other departments having similar activities ... [Chicago, H. G. Adair, I9I3.] II3 p. plans, tables, diagrs.

Reports on the budget of educational estimates and expenditures, Board of education, city of Chicago. Educational budget prepared by the Efficiency division ... February 27, I9I4, to May 2, I9I4. [Chicago, J. F. Higgins, printer, I9I4.] 49 p. incl. tables.

Partial Contents.

Classification of standard accounts.

Report on procedure in preparation of budgets and accounting control.

Rules governing compensation of civil service employees.

Report on the budget of educational estimates and expenditures, Board of education, city of Chicago. Educational budget prepared by the Efficiency division ... February 27, I9I4, to May 2, I9I4 . . [Chicago, J. F. Higgins, printer, I9I4.] $55^{8}$ p.

Contents [same as in edition above, except that detailed estimates are given for each organization unit].

Report on the investigation of prison labor and management, House of correction, city of Chicago. Inquiry conducted at the request of the Committee on finance, December II, I9I3, to March 24, 1914. Statutory provisions, organization, management, record system, inmates and prisoners, contract labor, extension of industries, present industries-conclusions and recommendations. [Chicago, Cameron, Amberg \& co., printers, I9I4.] 66 p. incl. illus., plan, tables.

Report on the investigation into organization and administration, Department of health, city of Chicago. Inquiry conducted at the request of Dr. George B. Young, Commissioner of healthMay 26, 19I4, to April 19, I9I5. Statutory and ordinance provisions, organization, administration, methods of procedure, equipment conditions, records and systems-conclusions and recommendations. [Chicago, W. J. Hartman co., printers, I9I5.] I6o p. charts, tables.

\section{Milwaukee, Wis.: Bureau of Economy and Efficiency and} Bureau of Municipal Research. In I9Io the Social Democratic Party succeeded in gaining control of the government of Milwaukee. A leading feature of its program was that of subjecting the government of the city to study with a view to perfecting its organization and methods of business. By a resolution of June I4, I9I0, the Committee on Finance of the Common Council of the City of Milwaukee was directed "to investigate the system of accounts of all departments of the City of Milwaukee and the operations and activities of all departments and powers granted to the city," and to submit to 


\section{AGENCIES OF PARTICULAR CITIES: OFFICIAL}

the council for adoption "a complete system of uniform accounts, vouchers and other forms that may be necessary or convenient for carrying out such system and recommendations for rendering more efficient and economical the administration of the city." For expenses connected with the preparation of this report $\$ 5,000$ was appropriated.

To carry out the purposes of this resolution and appropriation there was created an organization with the title "Milwaukee Bureau of Economy and Efficiency." This body in May, I9I I, issued a bulletin in which it discussed proposed plans of work, and indicated the studies and researches which it intended to make.

In I9I2 a change of government took place. The idea of subjecting the government to a thorough overhauling had such a strong popular support that the new administration declared its intention to continue the work projected by the bureau. Though it abolished the bureau it created in. its place a new bureau under the title of "Bureau of Municipal Research."

Following is a list of the publications of these two bureaus:

\section{PUBLICATIONS}

Bulletin, No. I-I9. Milwaukee, Wis., IgII-IgI2.

Contents.

No. I. Plan and methods in municipal efficiency, by B. M. Rastall. I9II. 29 p.

No. 2. Proposed consolidation of fire and police alarm telegraph system, by J. E. Treleven. I9II. 23 p.

No. 3. Garnishment of wages. I9I I. 27 p. Pub. by the Wisconsin Consumer's league.

No. 4. Proposed minimum wage law for Wisconsin ... Prepared for the Wisconsin consumer's league under the direction of J. R. Commons, I9II. $18 \mathrm{p}$.

(This bulletin was not published by the Bureau, but simply included in its series.)

No. 5. The refuse incinerator, by M. Cerf [and others]. IgII.

No. 6. Citizens' free employment bureau, by F. A. King. IgII. $15 \mathrm{p}$.

No. 7. Free legal aid, by F. A. King. I9I1. 16 p.

No. 8. The newsboys of Milwaukee. I9II. $96 \mathrm{p}$.

No. 9. Guide to exhibit and a review of the Bureau's work. Loan exhibit of the Census bureau. Milwaukee budget exhibit, Auditorium. Nov. 27-Dec. 3, IgI I. I2 $\mathrm{p}$. 


\section{EFFORTS FOR ADMINISTRATIVE REFORM}

No. 10. Plumbing and house drain inspection, by F. H. Elwell. I9II. $33 \mathrm{p}$.

No. II. Water works efficiency I. Water works survey, by Ray Palmer [and others]. I9II. $39 \mathrm{p}$.

No. 12. Reorganization of the system of garbage collection, by R. E. Goodell, I9I2. 24 p.

No. I3. Health department. I. Milk supply, by S. M. Gunn. I9I2. $45 \mathrm{p}$.

No. 14. Water works efficiency. 2. Present capacity and future requirements, by F. E. Turneaure. I9I2. $30 \mathrm{p}$.

No. 15. Health department. 2. Education and publications, by S. M. Gunn, and F. W. Luening. IgI2.

No. I6. Water works efficiency. 3. Operating efficiency, by Ray Palmer. I9I2. $30 \mathrm{p}$.

No. I7. Recreation survey, by Rowland Haynes. I9I2. 3I p.

No. 18. Health department. 3. Communicable diseases, by $\mathrm{S}$. M. Gunn. I9I2. $37 \mathrm{p}$.

No. 19. Eighteen months' work of the Milwaukee Bureau of economy and efficiency, by J. R. Commons. I9I2. $44 \mathrm{p}$.

Standardization of salaries of the city of Milwaukee. Report of the Bureau of municipal research, November 4. I9I3. [Milwaukee, Wetzel bros. printing co., I9I3.] 96 p. incl. tables, forms, fold. charts.

Efficiency and economy in municipal work by modern type of equipment. Milwaukee, Wis., Bureau of municipal research, 1915. $37 \mathrm{p}$.

Milwaukee's ash problem, by the Bureau of municipal research ... Milwaukee, C. H. Kronenberger \& Co., I9I5]. 45 p. incl. plans. Annual report, 19I4-I5. Milwaukee, I915-

Full title of report for I9I4-I5: Annual report, Bureau of municipal research, Milwaukee, Wisconsin.

New York, N. Y.: Commissioner of Accounts. The large powers of central administrative control over the government of the city of New York actually exercised by the Board of Estimate and Apportionment and by the comptroller through special agencies, as set forth in a subsequent section of this volume, doubtless make less necessary in this city than in others, where a less degree of central control obtains, a purely investigative agency. The city charter nevertheless makes provision for the Commissioners of Accounts, appointed by the mayor, who have wide powers of investigation and report. While the charter makes provision for two commissioners, it has been the custom since 1909 for the mayor to appoint but one.

Regarding the interpretation placed upon these provisions, 206 
a report ${ }^{1}$ prepared by the Commissioner of Accounts' office has this to say:

The work of the Commissioner of Accounts' Office is not limited to ferreting out irregularities and obtaining evidence of inefficiency or dishonesty; it includes also budget investigation, the study of important administrative problems and assisting in reorganizing bureaus or departments to secure greater economy and efficiency. The efficiency staff formerly under the Board of Estimate and Apportionment has recently been transferred to the Commissioner of Accounts. The staff is conducting efficiency studies looking toward the standardization of work processes in the various departments.

The foregoing may be supplemented by the following appreciation of its work contained in a report on New York City's Administrative Progress, 1914-1916.

Continuously through the past two years, the commissioner of accounts, in addition to carrying on his own work, has supplied several members of his staff to assist in constructive work under the direction of the chamberlain and to investigate and report on current administrative matters referred to the chamberlain by the mayor. He has also assisted the various heads of departments in their work of reorganization. Especially noteworthy assistance has been rendered to the commission on pensions in its investigation of the city's pension funds, and to the temporary central purchase committee organized to purchase supplies on contract for all departments under the jurisdiction of the mayor. The commissioner of accounts has coöperated in the preparation of the annual budget by detailing examiners to analyze departmental requests prior to their approval by the mayor for submission to the board of estimate and apportionment. The volume of constructive work done by the office is greater than that done at any previous period and indicates the necessity for continuing as a branch of the executive force an administrative staff to deal with general questions of a constructive nature.

${ }^{1}$ Government of the City of New York: A Survey of its Organization and Functions, 1915.

${ }^{2}$ P. 203. 


\section{EFFORTS FOR ADMINISTRATIVE REFORM}

Probably the most important report made by this office is the one prepared, in collaboration with the New York Bureau of Municipal Research, for the Constitutional Convention of I9I 5 on the Government of the City of New York: A Survey of its Organization and Functions.

In 1915 the office, in coöperation with the chamberlain, made a critical study of the county government within the city of New York and recommended the consolidation of county offices and the merger of certain of them with offices of the city government. It was estimated that the adoption of these recommendations would result in a saving of over $\$ 2,000,000$ annually.

During the administration of Mayor Mitchel, I9I3-1917, an additional agency for investigation existed in the office of the city chamberlain. That office had for years been recognized as a sinecure, to be filled by a purely political appointment. Mayor Mitchel took advantage of the existence of this office, required by the charter, to appoint to it Mr. Henry Bruère, then one of the directors of the Bureau of Municipal Research, and designating him as a sort of assistant to the mayor in matters of administrative reform. Under Mr. Bruère's direction, and in large measure in collaboration with the office of the Commissioner of Accounts, a number of investigations in various branches of the city's administration were made, and many important changes effected. Account of these is given in a report issued by the chamberlain in 1916, entitled New York City Administrative Progress, I9I4-I 6.

In practically all of the work above outlined the city offcials have had the coopperation and assistance of the New York Bureau of Municipal Research.

\section{PUBLICATIONS}

Report of the commissioners of accounts transmitting to His Honor the mayor a report of a special examination of the "Bureau for the collection of city revenue and of markets" of the Finance department to determine the correctness of the returns made, by corporations operating street surface and elevated railroads, to the Finance department, for car license and franchise tax in all of the boroughs of Greater New York, from October I, I889, to October I, I899. New York, M. B. Brown co., printers, I90I. I p. I., viii, 277 p. incl. fold. tables.

A report on a special examination of the accounts and methods of 208 


\section{AGENCIES OF PARTICULAR CITIES: OFFICIAL}

the office of the president of the borough of Manhattan, directed by Hon. George B. McClellan, mayor. Commissioners of accounts of the city of New York, July i6, I907. [New York, M. B. Brown press, I907.] I58 p. tables (partly fold.).

A report on a special examination of the accounts and methods of the night court 9th district city magistrates' court, boroughs of Manhattan and the Bronx. Directed by Hon. George B. McClellan, mayor. Commissioners of accounts of the city of New York, September 3, I909. [New York, M. B. Brown press, I909.] II7 p. incl. tables (partly fold.) 7 facsim.

A report on a special examination of the accounts and methods of the office of the president of the borough of Brooklyn, directed by Hon. George B. McClellan, mayor . . November 23d, I909. [With testimony.] [New York, I909.] 6 v. in 5. pl., 2 fold. tab., facsims.

The mayor's eye. An investigating commission by the use of which the mayor obtains independent information as to the records and workings of all departments of the city and county government, officially known as Commissioners of accounts ... New York, Commissioners of accounts, I9I0. 28 p. I 1.

A report on the progress of efficiency work in the borough of Queens during the year I9I2. [New York, E. D. St. George co., I9I3.]

[37] $\mathrm{p}$.

Report made to the mayor.

Government of the city of New York; a survey of its organization and functions, prepared for the Constitutional convention, I9I5, by the office of the commissioners of accounts, New York city, and New York Bureau of municipal research. New York, J. J. Little \& Ives company, I9I5. I p. 1., v-xxxi, I343 p.

Introduction signed: Leonard M. Wallstein, commissioner of accounts.

A report on office of city clerk and Board of aldermen. Examination and audit for the period from January I, I9IO, to September 30, I9I4, by Leonard M. Wallstein, commissioner of accounts. [New York, I9I5.] I2 p. incl. tables.

Report on a study of the effect of mandatory legislation upon the budget for the year I9I5. June I5, I9I5. Office of the commissioner of accounts, city of New York, Leonard M. Wallstein, commissioner. [New York, M. B. Brown printing \& binding co., I9I5.] I p. 1., ii-xxii numb. I., I 1., 77 numb., I. incl. tables. diagrs.

Report on special examination of the accounts and methods of the Board of elections of the city of New York directed by Hon. John Purroy Mitchel, mayor. Office of the commissioner of accounts city of New York ... [New York, M. B. Brown printing \& binding co., I9I 5.] 47 p.

Leonard M. Wallstein, commissioner of accounts.

Report on special examination of the accounts and methods of the office of the coroner in the city of New York, directed by Hon. John Purroy Mitchel, mayor. Office of the commissioner of accounts, city of New York. Leonard M. Wallstein, commissioner of accounts. [New York, M. B. Brown printing and binding co., I9I5.] $82 \mathrm{p}$. 


\section{EFFORTS FOR ADMINISTRATIVE REFORM}

Study of county government within the city of New York and a plan for its reorganization. Prepared for the Constitutional convention, I9I5, by the commissioner of accounts and the city chamberlain, New York City ... [New York, M. B. Brown, printing and binding co., I9I5.] v p., I I., 43 p. charts., fold. tables, diagrs. (I fold.).

Henry Bruère, city chamberlain, Leonard M. Wallstein, commissioner of accounts.

The work of the police surgeons and the retirement of policemen for disability. Leonard M. Wallstein, commissioner of accounts. [New York, J. J. Little \& Ives co., printers, I9I 5.] 26 p.

A report transmitted to the mayor, November 24 , I9I 5 .

City printing. Economics proposed in the printing incident to the preparation and adoption of the annual city budget. Leonard M. Wallstein, commissioner of accounts. [New York, I9I6.] $3 \mathrm{I}$ p.

The Division of combustibles, Bureau of fire prevention, Fire department, city of New York. An examination of its accounts and methods. Leonard M. Wallstein, commissioner of accounts. [New York, M. B. Brown printing \& binding co.], I9I6. 24 p.

The office of coroner in New York City. Summary of the findings of the commissioner of accounts in an investigation of the office and text of an act abolishing the same and creating the office of chief medical examiner. New York, New York short ballot association, I9I6. Io p. (Documents on county government.)

Bureau of supplies, Department of education, city of New York; examination of its accounts and methods. [New York, Press of C. S. Nathan, inc.], I9I7. 47 numb. I.

\section{PUBLICATIONS OF BUREAU OF CITY CHAMBERLAIN}

Administrative reorganization and constructive work in the government of the city of New York, I9I4. Henry Bruère, chamberlain. [New York, Press of C. S. Nathan, inc.] I9I5. 50 p. The reorganization of the office of chamberlain, I9I4, by Henry Bruère, chamberlain of the city of New York. [New York, C. S. Nathan, inc., I9I5.] 39 p. chart, fold. tab.

New York city's administrative progress, I9I4-I6. A survey of various departments under the jurisdiction of the mayor, conducted under the direction of Henry Bruère, chamberlain, city of New York, May, igi6. [New York, M. B. Brown printing \& binding co., I9I6.] $3,3 \mathrm{a}-\mathrm{f}, 5-35^{\mathrm{I}}$ p. plates, fold. tab.

Other Municipalities. Undoubtedly other municipalities have created agencies of one kind or another having for their function the taking of action looking to the improvement of their methods of administration. The city of Los Angeles, California, thus created an efficiency department in 1914. The work of this department seems to have encountered strong opposition almost from the start, and it was finally abolished 


\section{AGENCIES OF PARTICLLAR CITIES: OFFICIAL}

in 1917. During this period it published the following three reports:

I. The City Government of Los Angeles, Cal. Organization Charts, July I, I9I4, 48 charts.

2. First Annual Report Los Angeles County Civil Service Commission and Bureau of Efficiency for the year ending . June 30 , 1914.

3. City of Los Angeles, Summary of Budget Estimate for the Fiscal Year I9I 5-I9I6. May 2, I9I5. I9 p.

Much of course is also done by city comptrollers and other financial officers in the way of working out and installing improved systems of accounting and reporting. Among such cities special mention should be made of Philadelphia, Pennsylvania, the comptroller of which has not only devised and put into operation a modern system of accounting and reporting, but has published an excellent manual of accounting procedure describing the new system. 


\section{CHAPTER VIII}

\section{AGENCIES FOR INVESTIGATING THE ADMIN- ISTRATION OF PARTICULAR CITIES: UNOFFICIAL}

As has been pointed out in our introductory chapter, in which is traced the development of the modern movement for efficiency in the administration of public affairs, the origin of this movement is to be found in the rise of the conviction that good municipal government was not to be secured as a permanent possession by purely political action; that the problem of securing such a government was as much administrative as political, and that efforts should be more largely directed towards the improvement of the actual machinery and methods of administration, rather than to the selection of the persons who were to operate such machinery. It was logical that this feeling should first develop in respect to municipal government; since it has long been recognized that the duties of such government are primarily of a purely business character and as such should be conducted upon a business basis.

This conviction that the line of attack lay along the improvement of the purely business, or non-political side, of municipal government has led to the creation in a large number of our more important cities of institutions specially organized and equipped for this work. These institutions are generally known as bureaus of municipal research, though some of them are differently designated. Some have been established by and are conducted under the auspices of existing social agencies, such as chambers of commerce. Most, however, are independent bodies created by a group of citizens and supported wholly by voluntary donations.

In the following paragraphs is given an account of the establishment, work and publications of each of these bureaus in so far as it was possible to secure information regarding 
them. In respect to the matter of their publications, two things should be noted. The first is that only in small part do the results of the work of these bureaus appear in printed form. In many cases the work is done by direct conferences between officers of the bureaus and city officials, or by the former participating in the devising and installing of improved accounting and other business methods. In still others the results of the inquiries made by the bureaus are embodied in manuscript reports which have served their purpose when presented to the officers of the municipality interested. Only in a relatively few cases are these reports of a character that would warrant their publication in printed form. The second is that a considerable part of the material that is printed is issued for general propaganda purposes or to direct the attention to particular municipal happenings, and thus has no great permanent value. Material of this character appears in the form of leaflets or folders issued at regular or irregular intervals of time. No attempt has, therefore, been made to list in detail publications of this character.

The foregoing remarks regarding the publication activities of these bureaus have been given in order to make clear that the value of the work of these bodies is not to be judged by the amount and character of their printed publications.

In a sense the oldest and most important of the class of agencies treated in this chapter is the New York Bureau of Municipal Research. For reasons there set forth, however, this agency has been treated in a preceding chapter as an agency for studying the problem of municipal administration generally.

Philadelphia, Pa.: Bureau of Municipal Research, The first city to follow the example of New York and create a bureau of municipal research was Philadelphia. The establishment of this bureau was the direct result of the appreciation on the part of a group of citizens of that city of the value of the work done in New York. In 1908 the New York bureau was requested to lend its assistance in the establishment of a similar bureau in Philadelphia. After a preliminary visit by one of the directors of the New York bureau, a 
number of Philadelphia citizens visited the New York office to discuss plans. This was followed by a number of conferences, resulting in the pledging of a sum of $\$ 12,500$ for an experimental period of six months. The Philadelphia bureau was formally opened on November 9, 1908, by a staff detailed from the New York bureau under one of the directors of that organization.

Although some difficulty was experienced in the beginning in getting the confidence and coopperation of the mayor, the supporters of the movement were convinced, at the expiration of the six-month experimental period, that the institution was worth while, and accordingly decided to incorporate a local body separate from the New York bureau, which was done in the autumn of 1909.

The purpose of the bureau, as stated in its charter, is :

To serve Philadelphia as a non-partisan and scientific agency of citizen inquiry, which shall collect, classify, and interpret the facts regarding the powers, duties, limitations, and administrative problems of each department of the city government; to make such information available to public officials and to citizens, in order that inefficient methods of administration may be eliminated, and efficient methods encouraged; and to promote the development of a constructive program for the city that shall be based upon adequate knowledge and consideration of community needs.

According to a statement issued by the bureau, it accomplishes this purpose "by advancing sound methods of administration and securing constructive publicity concerning municipal problems." Its scope comprehends finance and accounts, public works, safety, health, education and charities. It "provides a clearing house of information concerning public questions and government, maintains a trained staff to study community needs and community acts, submits unbiased, impersonal scientific criticism to officials and citizens, without regard to politics and personal favor," and "supplements criticism with positive proposals and constructive work." It prepares descriptive statements for the officials responsible for the governmental units surveyed, gets the officials' verification of the facts as found, prepares critical and constructive 
reports, and coöperates in installing the improvements recommended.

The governing body of the bureau is a board of twentythree trustees, including the chairman, vice-chairman and treasurer. The work of the bureau is conducted by a director, an assistant director, a secretary, an accountant, a public employment specialist, a civil engineer, a librarian, a trained investigator and statistical expert.

The bureau usually has, in addition, a number of volunteer staff members and office assistants who are students at colleges in the vicinity. Heretofore, these volunteers were usually engaged on general assignments under the direction of a staff member and with opportunities for but little original work, but a new departure was recently made whereby volunteer students were given special original work for their theses. The topics for these theses were selected by the bureau and the theses must be approved by the bureau before they will be accepted by the college authorities. Volunteer staff members are accepted only on condition that they give at least fourteen hours per week to this work. The results of their work, if deemed sufficiently valuable, will be published at the expense of a special fund.

The work of the bureau since its organization covers a large range of civic activity, the principal studies being in the fields of education, weights and measures, accounting and finance, public health, civil service, public safety, public works, etc.

The first important work undertaken by the bureau was in the field of public education. In Igog a study was made of the Municipal Bureau of Compulsory Education, which bureau is charged with the enforcement of the compulsory school attendance and the child labor laws. The result of the study was a complete reorganization of that bureau from an inefficient service to a model of its kind.

An exhaustive study of negro education was undertaken by the bureau. The results of the study, which were pedagogical and psychological rather than administrative, were published by the United States Bureau of Education, and the recommendations made were influential in shaping the poli- 


\section{EFFORTS FOR ADMINISTRATIVE REFORM}

cies of the Philadelphia school authorities in the matter of negro education.

Ten other educational studies were made by the Philadelphia bureau resulting in pieces of work of varying lengths and of widely different degrees of importance. Principal among these was a study of special schools, resulting in a complete reorganization and a study of the Department of Supplies of the Board of Education, which study furnished the basis for a radical change in the organization and methods of that department. The bureau also prepared a complete digest of all the laws, ordinances and regulations pertaining to the schools.

A study of the weights and measures situation in Philadelphia resulted in the enactment of state legislation for the creation of a bureau of weights and measures in Philadelphia.

The field of accounting and finance claimed a large part of the money and energy of the bureau. Prior to Igog the accounts of every city department were, in effect, merely memoranda of cash transactions, and there was no systematic record or control of other assets. The bureau in coöperation with the comptroller brought about the installation of modern fund and expense accounts in the latter's office and modern systems of accounting in a number of other departments, notably the bureaus of charities and water and the electrical bureau. This was facilitated by the preparation of a manual of accounting by the comptroller's office, in coöperation with the bureau, which was printed and distributed to the various departments.

The bureau, in coöperation with the comptroller's department, prepared a uniform classification and budget program for the city government which was accepted by the mayor, but adopted only in part by the councils. This subject of budget making has been the most costly single study undertaken by the bureau.

Numerous other accounting and financial studies have been undertaken by the bureau, at least one member of the staff, and usually more, being always engaged on some study in this field. These studies include a calculation of the expected borrowing capacity of the city for the next ten years, coöperation with city bureaus in solving their accounting 
problems, a survey of the Board of Revision of Taxes, work with the mayor's committee on new sources of revenue, and a number of others.

Among the earliest effective studies of the bureau were those made in the City Department of Health and Charities. In this field the bureau prepared a digest of all the laws and ordinances pertaining to public health which was printed as a public document and is in constant use by the department.

A survey of the Division of School Medical Inspection made by the bureau resulted in a complete reorganization and standardization of methods.

An exhaustive study of the Milk Inspection Service made by the bureau resulted in the appointment, by the mayor, of a commission of six experts, which adopted the bureau's proposals, bringing about a complete revision of the milk regulations and a reorganization of the inspection procedure. The bureau also coöperated in the conduct of the "Milk Show" in I9I I.

The bureau made surveys of the contagious disease hospital and the Philadelphia General Hospital, bringing about a modernization of business procedure such as introduction of stores control, standardization of specifications for supplies, etc.

In I9I4, the bureau, in coöperation with the Henry Phipps Institution and the University of Pennsylvania, made a joint survey of the conditions under which foodstuffs were sold in Philadelphia. The bureau's part of the survey included the city's inspection service and general control over the handling of foods. Attention was called to many defects due chiefly to inadequate appropriations.

Studies were also made by the bureau in the Division of Vital Statistics and in the fields of housing and sanitation, tenement house inspection and child hygiene.

The municipal civil service obtained considerable of the bureau's attention. In November, I9I4, a program of salary standardization was begun and much progress has been made, the Civil Service Commission enthusiastically coöperating. A large amount of preliminary work has been done and a compilation of comparative salary data has been printed. 
The bureau has entered upon several lines of work in the Department of Public Safety. It prepared a new patrolmen's manual, the first to be published in seventeen years, a copy of which was given to every member of the police force, and it organized a school of instruction in the City Bureau of Police. Constructive suggestions were made in matters of procedure in the police bureau, resulting in the printing of general orders instead of giving oral instructions, the introduction of efficiency records as a basis for promotion and discipline, and the establishment of more effective control over police property.

The bureau brought about the establishment of a school of instruction in the Bureau of Fires. Officers of the bureau were members of a commission on fire prevention, appointed by the mayor, which worked out a systematic and effective program of fire prevention work. In coöperation with the chief of the electrical bureau, a thorough reorganization of the administration, personnel and accounting methods of that service was effected.

In the Public Works Department, the bureau did effective work in bringing about the establishment of modern systems for handling and filing correspondence and reorganizing the inspection service of the highway bureau; reorganizing the janitor service, resulting in an annual saving of $\$ 30,000$ with better service; assisting in the solution of administrative problems in the director's office; studying the conditions attending the lease of the citizens' gas works to a private company; and preparing a digest of the laws governing the Public Works Department.

With the assistance of the bureau the director of the Department of Supplies was enabled to bring about a much greater centralization of purchasing. The bureau formulated standard specifications for a large part of the supplies bought by the city which were adopted by the department.

At the invitation of the presiding judge of the Municipal Court, the bureau made a study of the organization, methods and procedure of the domestic relations division of that court. As a result, it devised a new system for keeping case records and installed a complete system of mechanical tabulation of 
the social and other data pertaining to domestic relations cases.

The bureau coöperated in the preparation of a draft of a new charter for the city, providing for home rule powers, especially with respect to finance. The director of the bureau acted as secretary of a committee appointed for that purpose.

Other activities of the bureau include an inquiry into the use of mandamuses in Philadelphia, an investigation of city control of billboards, a study of fire insurance on city property, a study of licenses and new sources of revenue in cooperation with the Mayor's Advisory Committee on Finance, a survey of the heating and ventilation of school buildings, a brief survey of the sheriff's office, an examination of the committee system of the city councils, etc.

The bureau's publicity work consists mainly of the publication of a weekly bulletin entitled Citizcns' Business, usually a folder, in each copy of which, as a rule, but one topic is discussed. Reports of studies and surveys have also been printed in book and pamphlet form.

\section{PUBLICATIONS}

Citizens' business, No. 2-299.

A few numbers are in pamphlet form, octavo size.

Budget estimates, 1912, city of Philadelphia. Philadelphia, Bureau of municipal research, I9II. 30, I62 p.

A digest of the statutes and ordinances relating to public health governing the Department of public health and charities; with index and organization charts. Philadelphia, Dept. of public health and charities, I9II. I0, 246 p. 18 plates.

Editorial response to disclosure of a public emergency. Comment of Philadelphia newspapers on the weights and measures situation in Philadelphia. As shown by the report of the Bureau of municipal research. One week: March 6th to I 3 th, I9r I. [Philadelphia, Bureau of municipal research, I9II] cover-title, I5 p. Report No. I-Philadelphia, I9II-

Contents.

No. I. The weights and measures situation in Philadelphia; a report setting forth the results of the lack of a system of official inspection and regulation, together with a digest of existing laws and ordinances on the subject and a suggested legislative program. Submitted to the mayor March 3, I9II. I9II. 153 p. incl. tables, plates, facsim., diagrs.

Specifications for supplies, "Groceries, canned goods, fresh fruits 


\section{EFFORTS FOR ADMINISTRATIVE REFORM}

and vegetables and flour." Schedules printed by Department of supplies, I9I2.

Organization and administrative methods of the Board of revision of taxes of Philadelphia county. A descriptive statement ... [Philadelphia, Board of revision of taxes, I9I3.] 63 p.

Patrolman's manual. Printed under supervision and at expense of the Philadelphia Bureau of police. I9I3. 220 p.

Food inspection service in Philadelphia. April 14, I9I5. (In Henry Phipps institute ... Twelfth report ... Philadelphia, I9I6. p. 57-94.)

Comparative salary data, obtained from the payrolls of fourteen cities in the United States, forty-eight private establishments in Philadelphia and salary standardizations of seven American cities for one hundred and twenty-eight positions in municipal service, by the Bureau of muncipal research of Philadelphia; staff member in charge of this study, William C. Beyer. [Philadelphia, Bureau of municipal reseach], I916. I p. $1 ., 76$ p. incl. tables.

\section{ARTICLES}

Burks, J. D. Outlook for municipal efficiency in Philadelphia. American academy of political and social science. Annals, May, I9I2. v. $4 \mathrm{I}: 245-6 \mathrm{I}$.

Coopperation of the Bureau of municipal research with city officials.

Burnham, George. Philadelphia bureau of municipal research. National municipal review, July, I916. v. 5: 465-9.

Gruenberg, Frederick P. The Bureau in Philadelphia. The first municipal research venture outside New York. (In Municipal research, New York, Sept., I9I6, No. 77, p. 8-27.)

Cincinnati, Ohio: Bureau of Municipal Research. The Cincinnati Bureau of Municipal Research was established in 1909. The organization is a committee of citizens brought together as an unofficial agency of the people. It is sustained by voluntary contributions. The governing body is a board of six trustees, and the chief executive officer the director.

The purpose of the bureau, as stated in its reports, is :

To conduct a non-partisan study of the methods of work of the city and county governments with a view to recommending such modifications and improvements as it believes will promote the efficiency and economy of municipal administration, and through reports, to keep the people informed as to the results of its findings and recommendations.

The first work undertaken by the bureau was the preparation of an exhaustive technical report on street and commercial lighting which was submitted with recommendations to 
the director of public service. The adoption of a number of these recommendations effected a reduction in the cost to the city.

The bureau was instrumental in bringing out facts whereby two paving contracts were enjoined, preventing a futile expenditure of about thirty thousand dollars. It inspected paving contract work on certain streets thereby securing a more thorough compliance with specifications and better pavement; made a study of relative costs of various types of pavement; and effected a complete revision of the paving specifications resulting in free and open competition in bidding.

The bureau coopperated with city officials in the preparation of an ordinance regulating the deposit of city funds.

It assisted in organizing the Mayor's Bureau of Efficiency to make efficiency studies in the various departments of the city government, but this bureau was abolished when the administration changed.

It coöperated with city officials in planning the partial reorganization of the city government on January I, I9I2, resulting in the consolidation of a number of the departments, and the centralization of the telephone and garage services.

It devised and coopperated in the installation of systems of accounting for the entire city government and of administrative methods in a number of the city departments; cooperated with the Mayor's Efficiency Bureau in the preparation of a uniform expense classification applicable to all city departments and a report on the standardization of salaries; coöperated with the city purchasing agent and auditor in the reorganization and standardization of the purchasing methods of the city.

With the coöperation of the city officials, the bureau devised the form and prepared five semi-annual appropriation ordinances; it drafted the 19I3 budget and coöperated with the Mayor's Efficiency Bureau in drafting the budget for I9I4, and with the assistance of the mayor, conducted two municipal budget exhibits in I9I2 and I9I3.

The bureau coöperated with the State Educational Commission of Ohio in conducting an over-age survey of the Cincinnati schools; and with the Juvenile Protective Association 
in an examination of the Truancy Department of the Board of Education, devising a new system of administrative records which was installed.

The bureau was represented at all the meetings of the City Charter Commission and coöperated with all of its committees in the framing of a proposed new charter.

At the request of the City Club, the bureau investigated the administration of the Municipal Court and made recommendations which, if adopted, would result in considerable saving of expense.

Organization charts have been prepared showing in detail departmental functions, with the duty and salary of each employee both of the city and the county governments.

The bureau has advocated the close scrutiny of all bonds issued and of all programs for public improvements, and has collected data on city indebtedness which will serve as evidence of the necessity for and the value of an improvement on bond budget.

The bureau publishes biennial reports of its operations and special reports of the various studies which it undertakes. These are shown in the following list:

\section{PUBLICATIONS}

The Cincinnati Bureau of municipal research: its first year's work, Igro-IgI I (?).

Second annual report, I9I0-19II. I6 p.

Report for the two years ending June 30, 19r3. $30 \mathrm{p}$.

Report ... for the two years ending June 30 , $1915.16 \mathrm{p}$.

Budget report No. I. The city's annual budget. March 3I, I9II. I5 p.

Paving reports, Nos. I-6.

Contents.

No. I. Wood block paving contracts. A brief submitted to the Board of control ... Feb. 12, 1910. 22 p.

No. 2. Wood block paving: the Reading Road contract.

No. 3. Wood block paving. Is high-priced oil a business proposition? June 23 , I910. 4 p.

No. 4. Wood block paving: Is high-priced oil a commercial proposition? What manufacturers, dealers and experts say about the Cincinnati specifications.

No. 5. What is being done on the Reading Road. Oct. 7, I9Io. $12 \mathrm{p}$.

Reply of Director of Public service to Paving report No. I of Bureau of municipal research. Rejoinder of Bureau of municipal research to Director of Public Service, Feb., I9Io. 7 p. 
Reply to Chief engineer's communication to Director of Public service in re the Bureau's Paving report No. 5. Nov., I9ro.

I4 p.

Street lighting report No. I. Feb. I8, 19II. I3 p.

The Board of health. April, I9II. I5 p.

Deposit of city funds; the results of an investigation into the protection and rates of interest for city funds on deposit. June, I9II. $22 \mathrm{p}$.

Extracts from report of the Bureau of municipal research on the business department of the Cincinnati Board of education. I9I3. $8 \mathrm{p}$.

Information for citizens, No. I-2.

Contents.

No. I. Extracts from report of the Bureau of municipal research on the business department of the Cincinnati Board of education... May 2, I9I3. 8 p.

No. 2. Suggestions for an improved system of budget making and a more systematic control over school expenditures. Extracts from a report submitted to the Committee on funds and claims of the Cincinnati Board of education. May 23, I9r3. $7 \mathrm{p}$.

Over-age in the Cincinnati elementary day schools. A preliminary analysis by the Ohio State school survey commission and the Cincinnati Bureau of municipal research. Cincinnati, I9I3. Io p. tables.

Schools as social centers. I9I3. 6 p.

Bond issues to be voted on November 2, 1915 . . Cincinnati [1915]. [9] p.

Report on the Municipal court of Cincinnati ... [Cincinnati, 19I5?] I6 p.

Reports to the City club of Cincinnati by its Committee on public utilities in matters relating to pending valuation of street railroads, gas and electric systems. 19I5. $6 \mathrm{p}$.

The House of refuge.

Juvenile court of Hamilton County.

Report on the Truancy department of the Board of education. (abridged.)

Report on the traction ordinance submitted to the trustees of the Cincinnati Bureau of municipal research by Mr. Alfred Bettman, special counsel of the Bureau on traction matters, Cincinnati [1917]. $12 \mathrm{p}$.

\section{ARTICLES}

Miles, R. E. Cincinnati bureau of municipal research. American academy of political and social science. Annals, May, I9I2, v. $41: 262-9$.

Chicago, Ill.: Bureau of Public Efficiency. ${ }^{1}$ When the "Merriam Commission," after about one and one-half years

${ }^{1}$ The following is taken almost wholly from the account of the bureau given by its director in Municipal Research, No. 77, Sept., 


\section{EFFORTS FOR ADMINISTRATIVE REFORM}

of successful activity, was about to terminate its labors in I910, ${ }^{1}$ it was thought by a number of public-spirited citizens that it would be beneficial to have an unofficial body which would continue the same general lines of work and which would carry on continuously analytical and constructive studies of the organization, activities, and expenditures of the city government and of the other local governments, at the same time suggesting plans for the betterment of the public service. This desire found expression in the creation in 1910 of the organization known as the Chicago Bureau of Public Efficiency.

The bureau is governed by a board of trustees appointed by the directors of the City Club of Chicago, the president of which is ex-officio a trustee of the bureau. There is, however, it is stated, no other connection between the two organizations. The bureau started with pledges to the amount of $\$ 100,000$ for its support. Subsequently new subscriptions at the rate of $\$ 30,000$ a year for a five-year period were secured.

At the outset it was planned to carry on inquiries into the affairs of practically all the different Chicago governments simultaneously. The territory comprising Chicago has a multiplicity of governing bodies, most of which escape the light of publicity that is directed upon the city government. There are the county government, the sanitary district, and several independent park boards. The Board of Education, the Library Board, and the Municipal Tuberculosis Sanitarium also have separate taxing powers, though their trustees are named by the mayor.

The difficulty in maintaining rigid scrutiny over so many diverse and complicated schemes of local government were found, however, to be almost insurmountable, and it was, therefore, decided to restrict the range of the bureau's activities. It was thought that better results would be obtained by concentrating from time to time upon a more limited number of specific problems. In pursuance of this policy consider-

1916, Citizen Agencies for Research in Government. The language of the author has been largely followed though the account is much condensed.

${ }^{1}$ See p. 200, supra. 
able work has been done in connection with the affairs of the county government. This accounts in part for the fact that so many of the reports of the bureau relate to that subject and that more reports have not been put out recently, since during the past two years considerable work has been done in the county fee offices, the results of which were presented orally to the judges of the Circuit Court but were not embodied in published reports.

Following is a summary of some of the accomplishments of the bureau as listed in a booklet published in I9I 5 :

I. Timely action on the part of the Bureau has so far prevented the payment by the City of Chicago of three quarters of a million dollars in the disgraceful voting machine deal. Litigation is now under way which, there is reason to believe, will be successful in saving this entire amount for the taxpayers.

2. The Bureau exposed the practices in the County Treasurer's Office which have resulted in the loss of large amounts of interest to the County. During the four-year term of the last County Treasurer this loss amounted to considerably more than $\$ 500,000$. As a result of the disclosures made by the Bureau, the newly-elected County Treasurer pledged himself before election to account for every dollar of interest earned on funds handled by him; also to keep books and records which shall be open to public inspection and which shall show his deposits of public moneys with the banks and the interest earnings thereon. Heretofore, the public has been denied information on these matters.

3. For three successive years the Bureau has submitted to the Judges of the Circuit Court data which have enabled them to effect a large saving in expense to the County by materially reducing the number of employes in the County fee offices over which the Judges have jurisdiction. The amount of this saving has been estimated at not less than $\$ 100,000$ a year. Acting upon such data, the Judges have also been able to induce several of the officials whose offices were affected to adopt changes in organization and methods which have resulted in increasing the efficiency of the offices. These changes in organization and methods are important also because they insure permanently the annual saving in salary expenditures above referred to. 


\section{EFFORTS FOR ADMINISTRATIVE REFORM}

4. The inquiry of the Bureau into the organization and methods of administration of the several park governments of Chicago emphasized the need for consolidating the park governments with the City of Chicago, and the large saving to the taxpayers-estimated at $\$ 500,000$ a year-which could be effected by such consolidation.

5. The way in which the Bureau serves a very useful purpose as a center of exact information on matters affecting local governing bodies is well illustrated by the part it has played in explaining the effect of tax rates in connection with bills for proposed park consolidation. There are very few persons in the community who understand the process of tax levying in such a way that they can explain the effect of proposed changes in rates. The Bureau was responsible for calling the attention of civic organizations and of legislative and council committees to the fact that, as first proposed, park consolidation bills - meant to be measures of economyin reality carried tax levy provisions that would operate to bring about heavy tax increases.

6. When occasion requires, the Bureau offers information and recommendations to the voters upon propositions relating to expenditures coming before them. The Bureau first directed public attention to the provisions for salary "grabs" contained in the proposed amendments to the Municipal Court act which were submitted to the voters and defeated at the election of November, I9II. These amendments proposed uncalled-for increases in the salaries of officials of the $\mathrm{Mu}$ nicipal Court amounting in the aggregate to about $\$ 165,000$ a year. Through their defeat, the City has already saved this amount for three years, a total of $\$ 495,000$. This illustrates how, in many cases, when a useless expenditure is once prevented, the saving effected accumulates from year to year thereafter, especially when there is an organization like the Bureau in the field looking out for a recurrence of the objectionable measure or expenditure.

7. Prior to the election of April 7, I9I4, at which proposed bond issues of the City of Chicago and of the County of Cook totaling $\$ 8,700,000$ were submitted to a referendum, the Bureau issued a statement to the voters advising the approval of two of the propositions, amounting together to $\$ 820,000$, and the rejection of the others, amounting to $\$ 7$.880,000 . The vote at the election accorded precisely with the recommendations of the Bureau. The two propositions 


\section{AGENCIES OF PARTICULAR CITIES: UNOFFICIAL}

recommended were carried; the other four were singled out for defeat:

8. In I9I I the Bureau criticised certain restrictions contained in the coal specifications of the Board of Education for I9IO. As a result of this criticism, the restrictive clause was taken out, and in I9I I twenty-nine bids were received as against six bids in I9Io. The price of coal at the mines and freight rates were both higher in I9II than they were in I9I0. Notwithstanding these facts, the bids were about 75 cents a ton less in I9I I than they had been in I9IO, and the aggregate saving to the Board of Education on that one year's purchase of coal was about $\$ 90,000^{\circ}$.

9. The publication entitled The Nineteen Local Governments in Chicago is perhaps the most broadly educational in scope of any of the reports of the Bureau. It shows the complexity of our local government due to the "multiplicity of overlapping taxing bodies with many elective officials." Unification of local governments and a short ballot are pointed out as the greatest needs of Chicago. So great was the demand for this report that an edition of I0,000 copies was exhausted within a year from the date of publication. The report has been extensively used as a text book in the public schools of Chicago.

The foregoing are only a few of the many important matters upon which the Bureau has been engaged. Not all of the results obtained can be measured in dollars and cents. The moral influence which an organization of this sort exercises in deterring the useless expenditure and waste of public funds is very great and should not be overlooked. Moreover, the publicity which the Bureau investigations have given to many defects in governmental organization and administration should ultimately bring about fundamental changes in conditions which will result in enormous savings and much better service to the public.

The latest report of the bureau, issued in January, I9I7, is entitled Unification of Local Governments in Chicago. It presents a plan for the consolidation into one municipal entity of all the governing agencies (including the county) within the territory comprising what is termed the metropolitan community of Chicago. The bureau recommends that the governing body for this unified government should 


\section{EFFORTS FOR ADMINISTRATIVE REFORM}

be a city council of thirty-five members, one from each ward, serving for four-year terms, subject to recall. Under the plan proposed, Chicago would have a modification of the city manager system, though the chief executive officer of the city would be called mayor rather than city manager. The mayor would be chosen by the council and would be its agent for administrative purposes. He would name the heads of all administrative departments, except the comptroller and the city clerk, who would be chosen by the council.

\section{PUBLICATIONS}

No. I. Methods of preparing and administering the budget of Cook County, Illinois. Report submitted to the commissioners of Cook County, January, I9II. 53 p.

No. 2. Proposed purchase of voting machines by the Board of election commissioners of the city of Chicago. May, I9I I. I4 p.

No. 3. Street pavement laid in the city of Chicago. An inquiry into paving materials, methods and results. June, I9I I. 4I p.

No. 4. Electrolysis of water pipes in the city of Chicago, July, I9I I. 7I p. incl. plates, plans.

No. 5. Administration of the office of recorder of Cook County, Illinois. Report prepared for the judges of the Circuit court, Sept., I9I I. 63 p. diagrs., fold. plan.

No. 6. A plea for publicity in the office of county treasurer. Submitted to the judges of the Circuit court by the Chicago bureau of public efficiency, October 9, I9II. II p.

No. 7. Repairing asphalt pavement. Work done for the city of Chicago under contract in I9II. October, I9II. $20 \mathrm{p}$.

No. 8. The municipal court acts, two related propositions upon which the voters of Chicago will be asked to pass judgment at the election of November 7. Oct. 30, I9II. 6 p.

No. 9. The water works system of the city of Chicago. Report of Dabney $\mathrm{H}$. Maury, to the Chicago commission on city expenditures. December, I9I I. 52 p. fold. tables.

No. 10. Bureau of streets, Civil service commission and special assessment accounting system of the city of Chicago. Reports submitted to the Chicago Commission on city expenditures. December, I9I I. II2 p.

No. II. Administration of the office of coroner of Cook County, Illinois; report prepared for the judges of the Circuit court. 68 p. fold. diagr.

No. I2. Administration of the office of sheriff of Cook County, Illinois; report prepared for the judges of the Circuit court, Dec., I9II. 26 p. fold. tab.

No. I3. Administration of the office of clerk of the Circuit court and of the office of clerk of the Superior court of Cook 
County, Illinois; report prepared for the judges of the Circuit Court. Dec., I9I I. 50 p.

No. I4. The judges and the county fee offices; statement to the taxpayers of Cook County. Dec., I9II. I5 p.

No. 15. The park governments of Chicago; general summary and conclusions of a report prepared by the Chicago bureau of public efficiency. Dec., I9II. I6 p. fold. plan, fold. chart.

No. I6. The park governments of Chicago; an inquiry into their organization and methods of administration. Dec., IgII. I82 p. plan, tables, diagrs.

No. 17. The office of clerk of the Circuit court and the office of clerk of the Superior court of Cook County, Illinois, a supplemental inquiry into their organization and methods of administration; report prepared for the judges of the Circuit court. Nov., I9I2. 27 p. diagrs.

No. I8. Administration of the office of clerk of the County court of Cook County, Illinois. Report prepared for the judges of the Circuit court. Nov., I9I2. 43 p. diagrs.

No. 19. The office of sheriff of Cook County, Illinois, a supplemental inquiry into its organization and methods of administration; report prepared for the judges of the Circuit court. Nov., IgI2. 26 p. incl. tab.

No. 20. Growing cost of elections in Chicago and Cook County; Dec., IgI 2. I6, [3] p. incl. tables.

No. 21. The voting machine contract, a protest against its recognition in any form by the City council of the city of Chicago. Jan. I, I9I3. I2 p.

No. 22. The office of county treasurer of Cook County, Illinois. An inquiry into the administration of its finances with special reference to the question of interest on public funds. Nov., 19r3. $67 \mathrm{p}$.

No. 23. The nineteen local governments in Chicago, a multiplicity of overlapping taxing bodies with many elective officials; Chicago's greatest needs are the unification of its local government and a short ballot. Dec., I9I3. 28 p., 3 l., [5] p. incl. tables, maps, plan, diagrs.

No. 24. The bond issues to be voted upon April 7, 19I4, a statement to the voters of Chicago and of Cook county. March, I9I4. I3 p.

No. 25. A second plea for publicity in the office of the county treasurer. A statement to the voters of Cook county. July, I9I4. Io p.

No. 26. The nineteen local governments in Chicago, a multiplicity of overlapping taxing bodies with many elective officials; Chicago's greatest needs are the unification of its local governments and a short ballot. 2d ed. March, 19r5. 32 p., 2 1., [5] p. incl. tables, diagrs.

No. 27. Unification of local governments in Chicago, Jan., I9r7. 98 p. incl. tables, map, diagrs.

No. 28. The city manager plan for Chicago. Draft of a bill for the reorganization of the municipal government, with explanatory statement. October, 1917. 6o p. 
No. 29. The county bond issues to be voted upon November 6, I9I7. Statement to the voters of Cook County. Oct. 30, I9I7. $6 \mathrm{p}$.

No. 30. Primary days and election days as holidays.... An instance of governmental absurdity and waste. Nov. 5, 19I7. II p.

No. 31. Chicago's financial dilemma. Reply of the Chicago bureau of public efficiency to a letter from the chairman of the Committee on finance and the City comptroller asking civic organizations to coöperate in urging a special session of the Legislature to provide financial relief for the city. December, 1917. $23 \mathrm{p}$.

No. 32. The water works system of the city of Chicago. Dec., 1917. 207 p. illus. charts. (part. fold.)

No. 33. Universal metering of Chicago's water supply. The need for it. What it would accomplish. July, 1918. $20 \mathrm{p}$.

No. 34. Excess condemnation, why the city of Chicago should have the power, in making improvements, to take property in excess of actual requirements. Lessons to be drawn from certain unfortunate aspects of the Twelfth Street and Michigan Avenue widenings projects and the proposed Ogden Avenue extension. Sept., 1918. 58 p.

\section{ARTICLES}

The Chicago bureau of public efficiency. June, I9ro. I3 p.

The Chicago bureau of public efficiency. Some opinions of its work. 1915. 24 p.

The Chicago bureau of public efficiency. What it has accomplished. I915. $8 \mathrm{p}$.

The Chicago bureau of public efficiency. Municipal research, New York. Sept., I916, No. 77, p. 28-36.

Dayton, Ohio.: Bureau of Research. ${ }^{1}$ The Dayton Bureau of Research was organized in October, 1912, under the name of Bureau of Municipal Research, which name was in 1916 changed to Bureau of Research. The bureau was discontinued in 1918 on account of lack of funds. The declaration announcing the establishment of this bureau stated that it was "a non-political civic organization, supported by voluntary contributions of citizens," and that its purpose was "to give to the public accurate, complete data relative to the condition of the city government; and to coöperate with city

${ }^{1}$ The following account of the Dayton bureau is based almost wholly on the account of that bureau given by its director in Municipal Research, No. 77, Sept., 1916, Citizen Agencies for Research in Government. To a considerable extent the language of the author has been followed though the account is much condensed. 


\section{AGENCIES OF PARTICULAR CITIES: UNOFFICIAL}

officials in the installation of the most modern system of conducting public business."

During the first years of its existence the bureau was supported almost solely by its founder, Mr. John H. Patterson, of Dayton, but it was thought that better results could be obtained by widening the managing board and extending the number of contributors. In May, I9I6, therefore, a new plan by which a greater number of citizens could participate by giving both moral and financial support to the movement was carried out, and as a result contributions were secured from about 150 contributors. At the same time a board of fifteen trustees was elected.

The first activity of the bureau was to urge upon the city the value of an itemized budget in place of the partial lump plan then employed. With the coopperation of the mayor, the board of control and other city officials and through the appointment of a local budget commission of which the director of the bureau was a member, steps were gradually taken toward the perfecting of a scientific budget. In September, I9I4, the budget classifications were revised and new forms were prepared by the bureau for the budget of 1915 and this revised procedure was adopted and has since been followed, the bureau assisting each year in its compilation. The detailed work and compilation of the I9I6 budget, as well as of all the previous budgets, was done by the bureau. The classification of accounts, which was devised by the bureau, is based upon the nature of the goods and services rather than the objects of expenditure.

Much assistance was rendered by the bureau in the work of cutting down the estimates for expenditures so as to bring them within the actual anticipated income. At the request of the bureau public hearings on the appropriation ordinance were held for the first time in I9I3.

In November, I9I2, the bureau began a campaign for a new charter by sending out a representative to study a number of commission-governed cities. The bureau's staff members then spent nearly half their time during the campaign period in speaking and other publicity work, preparing data, reporting speeches, writing circular letters, and assisting the 
Citizens' Committee in general. After the election of the charter commission, the bureau suggested an outline for a complete charter and recommended the appointment of five committees to consider as many divisions of the document. The director of the bureau worked on the drafting of the proposed sections, all but one of which were accepted with minor changes.

With the inception of the commission-manager form of government on January I, I9I4, the bureau assisted the offcials in their duties. After the charter election, data were secured and prepared in book form covering the organization of each department of the city government. A tentative outline for the new government was prepared, and a handbook containing the civil list, a statement of bond issues outstanding, digest of the city budget and a summary of the charter and rules of the commission was issued.

In November, I912, at the request of the codifying commission of the council, the bureau collected and correlated data relative to fees for permits, resulting in an increase of approximately $\$ 14,000$ annually in the income from such sources. In the summer of I9I4 the bureau undertook a study of new sources of revenue for the city commission.

The bureau, in I9I2, reorganized the accounting method in the Bureau of Revenue Collection of the City Water Service, which, with more efficient and economical management and added service, placed the water service on a self-sustaining basis.

In November, 1912, the bureau made a comprehensive study of the method of garbage collection and disposal, called attention to its unsatisfactory character, and brought about an improvement in this service. The bureau also secured the redistribution of street lights throughout the city.

A study of the public markets, outlining existing conditions, the character of vendors and the revenues received, was made by the bureau at the request of the Greater Dayton Association, resulting in increased revenues from this source and the establishment of additional markets, including a children's market.

The bureau, in I9I2 and 19r 3 , investigated the methods 232 
employed in the division of streets and called attention to inefficiencies and wastes in street paving, repair and cleaning services. Better methods and economies resulted from this study.

In July, 1913, the city issued $\$ 119,000$ in bonds for the complete motorization of the fire department. Later the bureau, through a survey of the fire department, made recommendations for the purchase and distribution of approximately $\$ 69,000$ worth of fire apparatus, resulting in the turning back into the sinking fund of $\$ 50,000$ of the original bond issue.

A survey made of the Division of Fires and the Division of Police by a member of the staff of the New York Bureau of Municipal Research resulted in the drawing up and adoption of a complete set of records, including a consolidated daily report for each division to go to the desk of the director of the Department of Safety each morning. A training school for members of the police force was suggested by the bureau. A member of the bureau staff accompanied $17 \mathrm{mem}$ bers of the Safety Department on an educational trip to New York City and other eastern points, and arranged with the Fire and Police Department in New York for placing these men so that they might receive valuable practical experience.

Many of the recommendations contained in the Safety Department survey were put into effect in the Division of Weights and Measures, records and forms were devised and installed, and the inspector was given a clearer idea of his duties.

The bureau financed the entire cost of preparing a complete modern city building code and outlined the records for the establishment of a division of building inspection.

At the request of the trustees of the police and fire pension funds, the bureau made a study of the pension funds with a view to the better protection of the present uniformed force.

Early in I9I3 the bureau coöperated with the Board of Health in the installation of a new system of filing and recording sanitary reports, the establishment of a pin-chart on contagious diseases, a revival of milk analysis after a 
lapse of two years, and the preparation of a score card system and more adequate inspection of dairies.

In May, I9I3, the bureau, through a staff member of the New York Bureau of Municipal Research, undertook a complete study of the administration of the Board of Health, resulting in the preparation of an outline of constructive suggestions for extending the service and increasing the efficiency of the department. The bureau assisted in installing the records recommended and in reorganizing the department. Eight bulletins consisting of the survey report and follow-ups were issued on this subject. Early in 19I4, at the request of the chief health officer, the bureau assisted in the installation and revision of a complete system of record keeping, and it continued to keep in touch with this service.

In February, I914, as a result of a statement prepared by the bureau, setting forth the needs of a city laboratory, a Bureau of Bacteriology and Chemistry was established.

An examination of the purchasing activities at the city workhouse in February, I9I3, was followed a year later by the installation of a system of cost and accounting records covering the maintenance of prisoners.

At the recommendation of the bureau an appropriation was made in January, I914, for the establishment of a City Bureau of Legal Aid where free legal assistance is given to those otherwise unable to obtain it. The activities of this new bureau resulted in driving loan-sharks out of the city.

The bureau, coöperating with the supervisor of recreation, brought about an enlargement of the plans of the Division of Recreation and recommended the establishment of additional social centers.

Upon the installation of the new government, the bureau, at the request of the Department of Finance, undertook a complete revision of the accounting system and the installation of a new method of procedure, in which work the aid of the Cincinnati Bureau of Municipal Research was had.

In November, I912, the bureau undertook to collect information in support of a proposal for the establishment of a centralized city purchasing department. In September, I9I3, blanks and procedure for the office of the purchasing agent 
were prepared ready for installation when the new government was placed in operation.

Early in I9I3 a study was undertaken by the bureau of the requirements of the sinking fund with a view to presenting a more equitable scheme of liquidating the funded liabilities of the city, and in January, I9I4, a complete statement of the city's bonded debt, classified by actual maturity, interest, etc., was submitted to the sinking fund trustees, and the annual interest and sinking fund requirements on all outstanding bond issues of the city were calculated by the bureau and submitted to the Finance Department.

The bureau prepared a series of charts showing the interlocking of social agencies within the city and the activities of the Department of Public Welfare. Later, by the use of a special fund raised for the purpose, the bureau made a survey of the nine private charities of the Federation for Charity and Philanthropy. As a result of this survey many constructive recommendations were put into effect by these organizations.

At the request of the Civil Service Board, the bureau prepared a complete list of city employees, with titles and grades of pay and considerable work was done with the board in outlining the general plan of activity of the board and in standardizing the positions and salaries of the civil list.

The bureau also made a study of paving and sewer conditions and calculations for two bond issues for improving and enlarging school activities in Oakwood, Ohio, and a survey of Jackson, Michigan, with constructive recommendations.

For several months in I9I3, at the request of the Governor of Ohio, the director of the bureau was loaned to the state to work on a program for the state budget in coöperation with the director of the Legislative Reference Library, the state auditor and other officials. As a result of this work budgeting procedure recommended by this board was adopted by the legislature and a budget commission was appointed by the Governor.

The director of the bureau participated in securing the passage of a bill providing for a state rural school survey. 


\section{EFFORTS FOR ADMINISTRATIVE REFORM}

The survey was directed by a member of the Training School for Public Service and resulted in the enactment of a complete revision of the rural school laws.

Other activities of the bureau have included the securing of better returns from lessees of public property, services rendered in flood relief work, studying the matter of grade crossings, securing information for the location of a bi-county tuberculosis sanitarium, etc.

The bureau has issued a number of folders and booklets, and has prepared matter for magazines and the daily press, dealing with subjects of municipal health, such as public safety, public welfare, finance, taxation, accounting, schools, and other public problems. A list of the more important publications follows.

\section{PUBLICATIONS}

Appropriation ordinances; first [and second] half year of I9I3. 2 pts.

The budget of the city of Dayton, I9I4. 42 p.

The budget of the city of Dayton, I9I5. 52 p.

The budget of the city of Dayton, I9r6. $60 \mathrm{p}$.

Organization and administration of the Department of health of Dayton, Ohio. Report prepared for the Department of health. [19I3] 97 p. incl. tables, diagrs.

"A report of the activities of the Board of health for I9I2 . . The investigation was made ... by Dr. Carl E. McCombs of the Training school for public service of the New York Bureau of municipal research."

A plan to place the water works upon a self-sustaining basis and to complete the proposed additional water supply and betterment of the distribution mains for Dayton by providing that the water department pay from income all interest and principal of the water debt now outstanding and hereafter created, thus excluding all water issues from limitations of the bonded debt. 1913? $28 \mathrm{p}$.

Shall we change our city government? A statement of three types of municipal administration ... [1913?] I6 p.

Survey of over-age and progress in the Dayton schools. I9I3? $46 \mathrm{p}$. Budget classification. I9I4? I6 p.

A charter primer. I9I4? $24 \mathrm{p}$.

Over-age and progress in the public schools of Dayton, 1913-19I4. I9I4. $20 \mathrm{p}$.

"A second study of 'Over-age and progress' [supplementing the report for I9I2-I9I3] . . . tabulation of material, and the writing of the entire report was done by Mr. Arch M. Mandel, assisted by Miss A. Irene Dilks and Mrs. Paul Illman of the Bureau staff." 


\section{AGENCIES OF PARTICULAR CITIES: UNOFFICIAL}

Shade trees in Dayton, results of a brief investigation of Dayton's trees ... I9I4. [4] p.

Water improvement plans ... I9I4. 8 p.

One year of city management in Dayton. I9I5? 12 p.

Some facts about the tax rate, by C. E. Rightor. Sept., I9I5. [12] p.

Some types of city government. I9I5? I2 p.

Why the Bureau of municipal research should be continued in Dayton ... March, I9I6. 8 p.

Reports on Dayton's school administration. No. I-April, I9I7Contents.

No. I. Building new schools for Dayton's children. April, I9I7. [ig p.]

Research progress facts; a year of governmental research with certain facts about our city, county and schools, and their progress during I9I6-1917. I9I7. $39 \mathrm{p}$.

\section{Miscellaneous Folders}

The city manager and the baby. (folder)

A complaint suggestion bureau. (folder)

Diphtheria epidemic versus diphtheria prevention. (folder)

Government by deficit, No. I-3. folders.

Health bulletins. 8 folders.

Infant death rate. (folder)

Motor-driven fire apparatus bids. (folder)

The municipal exhibit. I9I5. (folder)

Organization of the Bureau of municipal research. (folder)

Some acid tests of city manager government. (folder)

Swat the fly. (folder)

\section{Reprints}

Annual report of the City commission for 1915. $36 \mathrm{p}$.

Budget making for small cities, by Lent D. Upson [director of the Dayton bureau of research]. I9I5. I4 p.

Reprinted from The Annals of the American academy of political and social science, November, I9I5.

Budgetary procedure under the manager form of city government, by Arch M. Mandel. I3 p.

Reprinted from The Annals of the American academy of political and social science, November, I9I5.

The city manager and social justice, by Dr. D. F. Garland. I9I6. 5 p. Reprinted from the Rotarian, v. 8, No. 4, April, I9I6.

The city manager at work, by Lent D. Upson. I9I6. $4 \mathrm{p}$.

Reprinted from the Rotarian, v. 8, No. 2, Feb., I9I6.

The city-manager plan of government for Dayton, by L. D. Upson, director, bureau of municipal research. Reprinted by permission from the National municipal review, October, I913. [8] p.

Reprinted in response to requests for a digest of the Dayton charter.

Comment on the Dayton charter, by Lent D. Upson. Io p.

Reprinted from National municipal review, v. 4, No. 2, April, I9I 5 . 


\section{EFFORTS FOR ADMINISTRATIVE REFORM}

The law and public welfare, by Dr. D. Frank Garland. 7 p. Reprint of the city charter. 32 p.

Reprint of the Dayton charter. 64 p.

\section{ARTICLES}

Coöperation between city officials and private efficiency organizations. Modern city, Sept., 1917. v. $2: 26-7$.

Describes the work of the Dayton bureau of research.

The Dayton bureau of research. [Prepared for Municipal research by Mr. C. E. Rightor, director of the Dayton bureau of research. n. p., 1916. 27 p.

Reprinted from Citizen agencies for research in government, the issue of Municipal research, No. 77, Sept., I916.

Milwaukee, Wis.: Citizens' Bureau of Municipal Efficiency. In the chapter on official municipal government research agencies account has been given of the establishment, in I9IO, by the city government of Milwaukee, of a Bureau of Economy and Efficiency and the reorganization of this bureau in I9I 2 under the name of Bureau of Municipal Research.

Considerable delay occurred in the organization of this second service and in the appointment of its director. Unwilling to wait longer for action by the city authorities, and believing that there was need for an independent research agency, certain citizens of the city called in the assistance of the New York Bureau of Municipal Research, first, to make a preliminary survey of the various departments of the city and then to aid in the creating of a purely private research agency. Funds for a number of years were secured or pledged, and on May 27, 1913, there was incorporated the Citizens' Bureau of Municipal Efficiency.

The purposes of this bureau as set forth in a bulletin issued by it were:

To promote efficient, economical municipal government; to promote the adoption of scientific methods of managing and supervising municipal affairs and accounting and report on details of municipal business, with a view to facilitate the work of public officials; to secure constructive publicity in matters pertaining to municipal problems; to collect, classify, analyze, correlate, interpret, and publish facts as to the administration of municipal government, and generally to do 
all and everything lawful and proper which may be necessary or expedient for the accomplishment of these purposes.

Since its organization, the bureau, working on a coöperative basis with the city departments, has furnished assistance to the city comptroller, the Commission of Public Works, the Bureau of Bridges and Buildings, the Bureau of Sewers, the Bureau of Purchases and Stores, the Bureau of Street Sanitation, the Bureau of Illumination Service and the Fire Department, and it has aided in installing a system of pay-roll control for the city service and in the revision of the rules and methods of the Civil Service Commission.

It has made surveys of the Department of Public Works, the purchasing methods of the entire city government, the Fire Department, and the asphalt situation; preliminary surveys of school buildings and building sites and the street lighting question; and a preliminary report on city finance.

It has advised with various department heads and officials relative to the perfecting of budget-making methods, the control of the common council contingent fund, the control of the transfer of budget appropriations, the perfecting of methods of levying and billing taxes and special assessments, and the improvement of office procedure and methods. It has publicly advocated measures which, in its opinion, would be beneficial for the city, such as the ward reorganization proposed by the City Bureau of Municipal Research.

Through the installation of improved accounting systems and the perfection of office methods and procedure by the comptroller, with the assistance of the bureau, overdrafts of funds have been eliminated and daily appropriation balances made available, and the comptroller's office has been placed upon a more efficient basis.

A member of the staff of the New York Bureau of Municipal Research designed a uniform cost system for the Department of Public Works which has been installed in the Bureau of Bridges and Buildings and the Bureau of Sewers of this department. As a result these bureaus are in a position to keep close control over their service costs and the cost of materials and supplies. This system is now being installed 


\section{EFFORTS FOR ADMINISTRATIVE REFORM}

by the Citizens' Bureau in other bureaus of the Department of Public Works.

In order to effect a more efficient system of city purchasing, a plan of organization and procedure was adopted whereby a central purchasing committee was formed, consisting of the mayor, commissioner of public works, secretary of the school board, public librarian, director of the museum and secretary of the park board; and a member of the staff of the Citizens' Bureau was appointed executive secretary of the committee. This central purchasing committee is not a legally constituted body, and the bureau is endeavoring to secure the passage of a proposed purchasing law legalizing centralized purchasing. It is estimated that a minimum annual saving of $\$ 200,000$ could be effected by this plan.

A survey of the Fire Department's methods resulted in the city's Bureau of Municipal Research being requested to make a study and report upon the motorization of the department and the organization of a central repair shop for all city departments.

As a result of a survey of the asphalt pavement situation a training school for pavement inspectors was organized and much helpful information was collected for the Bureau of Street Construction.

A survey of Milwaukee's school buildings made by the Citizens' Bureau at the request of the school board, resulted in the outlining of a definite building program.

In order to throw light upon the street lighting situation, the bureau prepared a resumé and compilation of all available data relating to that subject.

The bureau was requested to direct the work of a citizen committee appointed by the mayor to study the problem of framing a financial program for Milwaukee. An expert was employed to make a preliminary study, and the report was. submitted to the mayor and members of the committee. Another report was prepared by the bureau and submitted to the Wisconsin League of Municipalities. Bills embodying some of these recommendations have been introduced in the legislature.

The bureau has been endeavoring for several years to se240 
cure the adoption of a plan of standardization of public employment and engaged an expert who prepared a report giving a review of the movement for standardization of public employment and an appraisal of the proposed salary standardization plan for the Milwaukee city service. This resulted in the rejection of the faulty plan proposed to the council and in the adoption of a policy-determining ordinance setting forth the principles of standardization, and in the City Service Commission being requested to submit a report upon the classification and standardization of the present service. The commission has engaged a specialist to do this work. An early report is expected.

The bureau has had very few of its reports printed, most of the reports being submitted in memorandum form. A folder entitled Coöperative Citizenship is issued at irregular intervals. Following is a list of the publications and other reports issued by the bureau.

\section{PUBLICATIONS}

A report to the public. March, 1915. 19 p. Concerning the Fire department. I9I5. I8 p.

Helping Milwaukee. 1915. $12 \mathrm{p}$.

Review of movement for standardization of public employments and appraisal of the proposed salary standardization plan ... Report made . . . by J. L. Jacobs . . . Milwaukee, I9I6. 45 p.

The street lighting question, a summary. Citizens' bureau of municipal efficiency, Milwaukee, March, I916. [Milwaukee, I916.] 2 p. 1., I4 p.

Coöperative citizenship. Bulletin, No. I-Nov. 15, I916-

Contents.

No. I. Standardization of public employmenț. Nov. I5, I9I6. $2 \mathrm{p}$.

No. 2. Central purchasing No. I. The central purchasing committee. Feb. I, 1917. folder.

No. 3. Central purchasing No. 2. The purchase of coal by the Central purchasing committee. Feb. 12, 1917. folder.

No. 5. What the Milwaukee Citizens' bureau of municipal effciency is doing for the city and some of its plans for future work. Sept., 1917. [7] p.

No. 6. What city officials think of the work of the Milwaukee Citizens' bureau of municipal efficiency. Oct., I917. Io $\mathrm{p}$.

No. 7. What Milwaukee has done and what it needs to do adequately to control its expenditure of $\$ 2,500,000$ for salaries. Dec., I9I7. $14 \mathrm{p}$. 


\section{EFFORTS FOR ADMINISTRATIVE REFORM}

No. 8. A discussion of the referendums relating to the re-organization of the Common council. Feb., I9I8. 7 p.

No. 9. The work of the Citizens' bureau and its plans for future work. March, I9I8. I2 p.

\section{ARTICLES}

The Milwaukee citizens' bureau of municipal efficiency. Prepared for Municipal research, by Mr. John F. Putnam, director ... n. p., I9I6. 9 p.

Reprinted from Citizen agencies for research in government, the issue of Municipal research, No. 77. Sept., I9I6.

Milwaukee bureau of economy and efficiency, by J. E. Treleven. American academy of political and social science, Annals, May, I9I2. v. $41: 270-8$.

Minneapolis, Minn.: Bureau of Municipal Research of the Minneapolis Civic and Commerce Association. ${ }^{1}$ In I9I3, a proposition for a home rule charter of the commission type had been voted down by the people of Minneapolis, whereupon the Minneapolis Civic and Commerce Association decided that the wisest policy would be to develop the best possible administration under the existing charter. Accordingly, a Bureau of Municipal Research was organized in December, I9I3, by a committee of the association and an experienced expert accountant placed in charge.

The functions of the bureau are set forth in the following statement issued at the time of its organization:

The purpose of the Bureau of Municipal Research of the Minneapolis Civic and Commerce Association shall be to promote efficient and economical government in the City of Minneapolis and in the County of Hennepin.

To this end the Bureau shall endeavor, through coöperation with public officials, to secure the adoption of scientific methods of accounting and administration and to collect, classify, analyze, correlate and interpret data with reference to the conduct of public affairs.

In coöperation with and in behalf of the public, the Bureau shall attempt to secure constructive publicity in matters per-

${ }^{1}$ The following account of the Minneapolis bureau is based almost wholly on the account of that bureau given by its director in Municipal Research, No. 77, Sept., I916. Citizen Agencies for Research in Government. To a considerable extent the language of the author has been followed though the account is much condensed. 


\section{AGENCIES OF PARTICULAR CITIES: UNOFFICIAL}

taining to municipal problems and so to interpret the facts as to secure an increased confidence on the part of the public in the activities of its officials and a more intelligent support for legitimate municipal projects and administration.

To act as a clearing house and point of contact between the citizens of Minneapolis and their public servants for the purpose of securing a better understanding and coöperation between them.

The first work undertaken by the bureau after its organization was an examination of the newly-organized civil service office of the Minneapolis city administration. By giving service and advice to the Civil Service Commission, it enabled that body to complete its records of the city employees, to secure uniformity in returns from the departments and to effect other economies.

The bureau has made surveys of the City Health Department, garbage and ash collection and disposal, the city hospitals, the business administration of the public schools, the comptroller's office, business procedure of the Institute of Arts, the Park Board and the Police Department. Special assistance has been given to the city purchasing agent, the Water Department, the Board of Tax Levy, the city assessor, the Fire Department, the administration of municipal baths, and to various committees of the city council and to the state legislature. A community survey was made of one city ward for the benefit of the social agencies at work there and the administration of one settlement house in the ward was studied.

At the request of the University of Minnesota a survey was made of the business administration of the medical school, and on its completion the bureau was asked to detail a member of its staff for a four months' study of the general business administration of the university.

Following are some of the more important constructive results of the bureau's work:

The bureau prepared a uniform expense classification which, for two years, has been used by the city departments in presenting their budget estimates, and it has given assistance to several of the departments in their work of analyzing 
their expenditures and preparing their estimates. This classification is to be used in the accounting systems of all the city departments as soon as they can be reorganized.

The bureau has assisted the comptroller in the installation of a new system of appropriation control which keeps the heads of departments informed of disbursements and encumbrances under their appropriations. This system enabled the departments operating under the current expense fund to decrease the over-expenditures at the close of the year from $\$ 35,578$ in 1914 to $\$ 14,422$ in 1915 .

The entire accounting system and business procedure of the comptroller's office has been modernized in so far as changes could be made without legislative enactment, and the process of reorganization has so awakened the interest of the employees of this department that they organized a class to study under the instruction of a member of the bureau staff the problems of modern municipal accounting.

In 19I5, a legislative act was approved providing for the complete centralization of the purchasing for the city government. In the drafting of an ordinance prescribing the procedure under which the city purchasing agent should handle the purchasing for all the city boards and departments, a committee of city officials was appointed of which the director of the Bureau of Municipal Research was a member.

In March, I9 15, the bureau was asked by the special council committee on finance to investigate a charge made by the newspapers, that the city clerk was unlawfully retaining fees taken in by his office. The bureau found that no records were kept of fees charged for acknowledgments, drawing papers, satisfactions, etc., fees which the city ordinances did not specially state should be turned in to the city treasury. The council immediately passed an ordinance requiring that all fees taken in by any city employee be turned over to the city treasurer.

In I9I4, the bureau made a survey of the Health Department, and it was found that 68 per cent. of the so-called health appropriation was being spent for garbage and ash collection and disposal. On recommendation of the bureau, the city council transferred the administrative supervision of 
this function from the commissioner of health to the city engineer.

Numerois other changes in administrative methods for the reorganization of the complaint system and of the system of accounting, etc., were made at the suggestion of the bureau.

At the request of the city hospital, the bureau assisted in preparing a system of daily and monthly reports from the heads of divisions to keep the head of the hospital currently informed of the work done and the occurrences which required his attention. The bureau coöperated with the hospital in the installation of a disease index and a new disease nomenclature. It also assisted in effecting economies in the hospital.

As a result of the bureau's report on the business administration of the Minneapolis public schools, the Board of Education consolidated its two business divisions, placing the auditor under the business superintendent. A system of job costs was installed to show the complete cost of each piece of work performed, also a system of stores accounting which increased the storehouse facilities and enabled the business superintendent to inspect more carefully goods received and to maintain a closer control over goods issued. The purchasing system was revised and a new accounting system conforming to the uniform accounts in the comptroller's office was installed. The bureau's assistance was used both in planning the reorganization and in putting the plans into effect.

The surveying of the business administration of the University Medical School resulted in the transfer of the departmental stores to the central university storehouse and in reducing the size of the machine shop force.

The Board of Park Commissioners accepted the recommendations as to its business procedure contained in the survey report of the bureau and asked that a member of the bureau staff take charge of the office during the process of reorganization. As a result, a complete new accounting system, a stores system and a central filing system were installed and other changes of administration were made.

A ward survey, the first of a series of sectional studies, 


\section{EFFORTS FOR ADMINISTRATIVE REFORM}

was made for the purpose of determining what sort of conditions, socially and governmentally, the city of Minneapolis provides for its citizens. This survey included a study of the park, school and library facilities, a provision of sewer and water, fire and police protection, housing conditions, the work of social agencies, and suggestions for needed changes were given to those concerned.

A police survey was begun in the fall of 1915 , resulting in the reorganization of a number of departments, changes in methods, and a revision of the entire system of police records.

In I9I6, the bureau engaged upon a comparative study of the cost of building inspection at the request of the building inspector; it assisted an officer of the United States Public Health Service in a survey which he made of the public health situation in Minneapolis; and it assisted the superintendent of the city hospital in the organization of the city physician service. The bureau keeps in close touch with departments already surveyed and gives them special service when called upon. Several requests for surveys have also been received by it from social and charitable agencies.

While the original purpose of the bureau included the same type of service for the county that has been rendered to the city, the pressure of municipal work has, as yet, prevented work with the county officials except some assistance rendered in preparing budget estimates for the County Board of Tax Levy. There is also an increasing demand that the state departments shall be given the opportunity to make use of the bureau's facilities for improving government administration.

The bureau has issued but one printed report and that is a reprint from Citizen Agencies for Research in Government, the issue of Municipal Research, No. 77, September, I9I6. All the other reports of the bureau are in manuscript form.

\section{PUBLICATIONS}

Budget bulletin No. I-August 5, I9I6-

Comparison of force employed on building inspection and the salaries paid in various cities. Comp. by the Bureau of municipal research of the Minneapolis civic and commerce association. [Minneapolis, I9I6] 2 charts on 8 sheets. 
Report on analysis of five year building program of Board of education; proposed two and three year school building programs by the Committee on municipal research. [Minneapolis, I917] $24 \mathrm{p}$.

The Bureau of municipal research of the Minneapolis civic and commerce association. n. p., I9I6. II p.

Reprinted from Citizen agencies for research in government. the issue of Municipal research, No. 77, Sept., I9I6.

Springfield, Mass.: Bureau of Municipal Research. Under date of December 26, I9I3, an offer was made by public-spirited citizens to the mayor and city council of Springfield to bear the expense of an expert survey of the city with a view to determining the advisability of establishing a permanent bureau for the introduction of efficient and economical methods of municipal administration. The offer was accepted and the services of experts from the New York Bureau of Municipal Research obtained, who made a report of 93 pages entitled Organization and Administration of the City Government of Springfield, Massachusetts.

As a result of this survey the Springfield bureau was established in January, I9I4. It is supported by the contributions of fifty or more persons designated as members and supporters. The manager is the only salaried officer. The functions of the bureau as defined in its articles of incorporation are:

To collect, classify, analyze, and publish facts as to the administration of municipal governments, to study scientific methods of municipal accounting and methods of efficient and economical municipal administration, to hold meetings for the discussion of such subjects and the education therein of the members of this corporation and to publish such information and discussions and such other matter as may be deemed to be conducive to the education of the public on such subjects, and generally to do everything necessary, suitable, and proper for the accomplishment of any of the above purposes and the attainment of any of the above objects provided the same be not inconsistent with the laws under which this corporation is organized.

These functions are further defined in the following statement issued by the bureau: 


\section{EFFORTS FOR ADMINISTRATIVE REFORM}

The Springfield Bureau of Municipal Research is a nonpartisan, non-political civic organization supported by the contributions of 52 civic spirited taxpayers for the purpose of : Gathering and publishing facts about city government; promoting efficiency in the city's business by coöperating with officials; securing desirable information for taxpayers through the installation of modern methods of accounting and budget making; assisting city officials in the solution of technical problems; advancing impartial constructive recommendations for increasing the usefulness and efficiency of government; it assumes that the citizen is or wants to be part of the government and if given the opportunity will be. It therefore advocates: Public budget making; public budget hearings and the issuance of adequate budget information in advance thereof; supplying citizens through periodical pamphlets and regular reports with information about government presented in an interesting and easily assimilated manner; widest publicity in all public affairs.

The Bureau is at the service of any official, city employee, or citizen and will endeavor to procure for anybody free of charge any information about civic affairs that it can. It earnestly solicits inquiries, suggestions, and criticisms. Literature will be mailed to any address upon request.

The activities of the bureau since its establishment are largely indicated by the list of publications which is appended. In addition, however, there has of course been work of an investigating and advisory character that does not appear in print.

The bureau's first work in Springfield was directed toward budget reform. A study was made of the city's existing budget system and as a result of this study certain recommendations were made by the bureau.

After numerous conferences in which state, city and bureau officials participated, it was agreed at a conference on May 24, I9I 5 , that the city should adopt the general budget plan advocated by the bureau, the details being left to be worked out by the city auditor with the assistance of the bureau. It was decided that the departments in submitting estimates should use standard forms, drawn by the bureau; that in making requests, a standard classification of commodities 
or objects of expenditure be used; that estimates for governmental services be submitted according to a standard classification of organization units; that code designations be used for all classifications; that standard uniform printed directions for preparing estimate sheets be furnished; and that estimates be submitted early enough for careful consideration before passage of the appropriation acts.

It was further agreed that the city would make certain changes in its departmental and general accounting along lines suggested by the bureau, the details of which were later worked out by the auditor with the assistance of the bureau.

In connection with the actual installation of the changes adopted, the bureau, at the auditor's request, performed practically all of the labor that was entailed.

In connection with the installation work, the bureau prepared descriptive articles and editorials for the daily papers, and the manager made addresses from time to time before citizens' organizations describing the work of the bureau.

The bureau also aided the charter commission by furnishing material and data to the drafting committees.

The present activities of the bureau consist in assisting the departments with their work under the new budget and accounting systems; obtaining the figures for setting up the central books according to the new plan; and taking up the adoption of additional forms and procedure for completing the revenue and fund control.

The bureau is at present endeavoring to secure the establishment of a central purchasing department, and a more simplified municipal register.

PUBLICATIONS

Public affairs, No. I-Springfield, 1913?-

Report on the proposed charter for the city of Springfield, Dec., 1913. $16 \mathrm{p}$.

The organization and administration of the Health department of Springfield, Mass. Report of a survey made by the Springfield bureau of municipal research, April, 1914. [Springfield, Mass.] 1914. $48 \mathrm{p}$.

Report on accounts of the city of Springfield with constructive recommendations ... Nov., 1914. [Springfield, Mass.] 1914. $39 \mathrm{p}$.

Report on present methods of budget making with recommendations for revision of procedure ... Oct., 1914. [Springfield, Mass.] I914. $49 \mathrm{p}$. 


\section{EFFORTS FOR ADMINISTRATIVE REFORM}

Report on the organization and administration of the Department

of charities, Springfield, Mass. April, I9r4. $32 \mathrm{p}$.

(I9I5) budget for the city ... with charts and statistics. March, I9I5. II2 p.

(I9I6) budget for the city with diagrams. March, I9I6. $78 \mathrm{p}$.

I9I7 budget. Reprint with diagrams. $57 \mathrm{p}$.

Comparative diagrams of standard charter forms and Springfield's organizations. 4 charts.

General semi-annual financial statement for city of Springfield under new system of accounts. Aug., I9I6. I8 p.

List of library books on charters and allied subjects.

Proposed city manager charter for the city of Springfield. 3I p.

Sample standard budget sheets. 4 sheets.

Directions for operating expenditure and expense accounts. Issued by the Mayor and Auditor. Nov., I9I5. 23 p. (Reprint)

Directions for preparing the budget. Issued by the Mayor. November, I9I5. 32 p. (Reprint)

General financial statement for the fiscal year ending Nov. 30, r9r6. 93 p. (Reprint)

\section{Akron, Ohio: Bureau of Municipal Research. ${ }^{1}$ The Bureau} of Municipal Research of Akron was formally organized in November, I9I4, and began active work on January I, I9I5. It is an independent body both in its organization and work, but is affiliated with the Chamber of Commerce, and was organized through the efforts of a former president of the chamber and of one of the committees. It was established for a period of five years. The governing body consists of the officers and a board of seven trustees.

Among the first studies made by the bureau was a survey of the accounting system of the city government, with the result that the general principles of the accounting scheme installed by the city auditor were made to agree with those laid down by the state. It spent much of the first six months of its work in studying in detail the financial condition of the city of Akron, resulting in the publication of a report on August I5, I9I5, giving a brief description of the reasons leading up to the annual deficits, and suggesting remedies. As an outgrowth of this study the bureau came to the assistance of the auditor in preparing his annual report so as to

${ }^{1}$ The following account of the Akron bureau is based almost wholly on the account of that bureau given by its director in Municipal Research No. 77, Sept., 1916, Citizen Agencies for Research in Government. To a considerable extent the language of the author has been followed though the account is much condensed. 
make that document reflect more truly the condition of the city.

The bureau has advocated the use of modern budget methods, and to that end analyzed the expenditures of each division and department for the year I9I4. Forms were drawn up and submitted to the city auditor and the mayor, who adopted them as official and requested department heads to submit their I9I6 budgets on those forms.

The bureau made a study and submitted recommendations concerning the civil service. It called attention to the lack of means to carry out the simplest features of the civil service law of Ohio. Attention was also directed to the need for higher standards in examinations, higher standards of service, more expert help to operate civil service, more and better records of examinations, candidates, etc., introduction of efficient ratings of employees, etc. While these recommendations have not been adopted, the bureau has, by request, assisted in preparing examination questions and has frequently been able to provide material for the Civil Service Commission.

Among the first investigations of the bureau was that of the new water-works system. The demand for an additional bond issue to be voted on seemed to warrant a complete statement of the project-legislation, bond issues, construction, contracts, etc., in order that the public might have proper information as a basis for voting.

Another of the early studies concerned a proposed sewage disposal plant. The particular question studied was that of the means by which the city could get a plant able to provide ample sewage facilities for Akron for some years at a total cost not to exceed the original bond issue of $\$ 446$,ooo. Facts placed before a special committee of the chamber led to a series of conferences with the city and state officials, the director and the engineer, resulting in a final reduction of $\$ 107,000$, thereby making unnecessary any additional bond issue to complete the plant.

The bureau aided the council and the Service Department in establishing the contract system for the collection of garbage. The advocacy of contract rather than municipal collection was based on the thought that the city might avoid 


\section{EFFORTS FOR ADMINISTRATIVE REFORM}

many mistakes and gain much valuable experience through the five years' life of the contract; also on the fact that the city was at the same time embarking on two other new municipal projects which could not be let privately, viz., a water plant and a sewage disposal plant. The bureau also assisted in preparing the specifications and the contract for bidders.

The bureau assisted in the preparation of a revised system of water rates.

During the winter of I9I4-I 5 the bureau, by request, undertook a study of the unemployment situation in Akron through an analysis of the records of the Free Employment Bureau.

The bureau rendered assistance to the city government by gathering information from other cities concerning the cost of constructing and operating workhouses. As a result of this study a project for the construction of a workhouse for Akron was abandoned.

During the first year of its operation the bureau made six surveys in three departments as follows: Accounting in the auditor's department; organizations and records in the council clerk's office; Bureau of Street Repairs; Bureau of Street Cleaning; Division of Streets in the Service Department, and a general reorganization survey of the same department. The coöperative plan of training for public service was begun shortly after the bureau was organized. Students of the Municipal University of Akrón were given assignments dealing with real city problems, that is, preparing a report on a comparison of city budgets for the past five years; analyzing the bond issues and preparing a statement of the city's bonded indebtedness; comparative study of charters in commissioned cities; study of water-main extension; and study of school statistics. Credit toward graduation is being given by the university faculty for this work.

The following excerpts, taken from the annual report of the director submitted January I, I9I8, show the nature of the more recent activities of the bureau.

The Bureau followed closely the work of the Finance Committee in its apportionment of the city's fund to the various departments and devoted a large part of January and 
July to this work. . . The Bureau furnished the Finance Committee "considerable information relative to estimatad revenues and past expenditures as a basis for its work in apportioning funds. When the work of the Finance Committee was completed the Bureau prepared and mimeographed the final drafts of the appropriation ordinances and distributed copies to each councilman, department head, newspapers and civic organizations. . . .

In response to a resolution (5358) passed by the Council inviting the Burean to recommend rules and regulations governing the office of the Clerk of the Council, the Bureau made a survey of this office and issued a report containing suggested rules and regulations with certain suggestions for improving the service. ...

The Bureau followed closely the action of the city when it was considering the question of reletting the contract for garbage collection or of beginning collection by the city and furnished information to its officials relative to the advantages and disadvantages of various methods and the experience of other cities. ... .

The City Council had for some time the need for a just and reasonable schedule of salaries throughout the city service which would serve as a guide to it in fixing the salaries of the various municipal employees. On January 22, a resolution was passed requesting the Bureau to coöperate with a committee of the Council appointed for that purpose, and on July 23 another resolution was passed authorizing the Bureau to obtain the necessary information from city officials and employees. An intensive study was made of every position in the city service and a description prepared outlining the duties of each position, the necessary qualifications an employee should have to successfully fill the position and the minimum and maximum salary which should attach thereto. Annual salary increases were also specified for each position. Studies were also made of the duties, qualifications and salaries paid similar positions in other cities and in the local industries in Akron.

During the year another advance step was taken in the establishment of a central purchasing department. The Bureau prepared a set of rules and regulations governing the purchasing department as a means of smoothing out some of the purchasing and accounting difficulties. ...

The necessity for a public dump being apparent for some. 


\section{EFFORTS FOR ADMINISTRATIVE REFORM}

time, the engineer of the Bureau suggested to the Service Director the possibility of making a dump along the line of the main outlet sewer. . . . The Bureau's engineer and the Service Director made a survey of the paved streets of the city to determine the extent and location of repairs needed and an estimate of the probable cost. ... At the request of the City Solicitor, the Bureau's engineer checked up the estimates and plans of the city for the Wolf Ledge Run Sewer. . . .

The Bureau prepared a series of five articles at the request of the new charter association outlining the need for a new charter. These appeared in the Akron Evening Times. Facts were also furnished this association for use in the preparation of a voters' pamphlet which was published and distributed by the association. Information has been collected, charts and tables prepared so as to have this available for the use of the charter commission which has been elected by the people and is now at work writing a new charter. . . .

At the request of the Mayor, the Bureau prepared a statement explaining the increases of the I9I8 City Budget request over I9I7. . . .

The Bureau prepared a report for the Taxation Committee of the Chamber of Commerce on the effect on the City of Akron of certain taxation bills which were before the Legislature. ...

A report on the schools of Akron made at the request of the Educational Committee of the Chamber of Commerce gives a complete description of the Akron schools and affords a working program for the betterment of the school system.

The bureau's policy with regard to publicity has been to get the facts and submit them for correction to the official involved, and to give out the facts either through the official or, if through the bureau only, at a time when the publication will not jeopardize progress.

The bureau issues a weekly official bulletin entitled $P u b$ lic Information, consisting of folders, usually of four pages each.

\section{PUBLICATIONS}

Annual report to the Board of trustees and to members of the Bureau of municipal research. Jan. I, 1916. I8 1. (typewritten)

- Same. Jan. I, I917. 46 1. (typewritten) 


\section{AGENCIES OF PARTICULAR CITIES: UNOFFICIAL}

Public information. Bulletin No. I-Aug. I7, I915-(weekly)

Contents. -

No. I. A report on a study of some aspects of the financial condition of Akron, Ohio. 3I p. [Later bulletins are in the form of small folders. The last one issued was under date of -.]

Digest of departmental city reports. 1915 .

Report of a study on improved water supply. I9I5.

Fundamental facts about Akron's proposed charter. I9I7. I2 p.

The Bureau of municipal research of Akron. 1916. I6 p. Reprinted from Citizen agencies for research in government, the issue of Municipal research No. 77, for Sept., I9I6.

Toronto, Canada: Bureau of Municipal Research. The Toronto Bureau of Municipal Research was organized on June 5, I9I4. It is a private non-partisan organization supported by membership dues and subscriptions.

The permanent staff, which is charged with the practical work of the bureau, is headed by the managing director, who has had extended training and experience in public administration and in research in the fields of public education, public health and municipal government.

The field of accounting is taken care of by a consulting accountant, a staff accountant, and accounting specialists employed from time to time. The bureau employs a civil engineer with special training in sanitary engineering, and experienced in public health administration and municipal research. Another member of the staff specializes in rendering coöperative assistance to citizen organizations for the social service. When a special opportunity for public service offers, demanding particular and unusual experience and training, the bureau employs a specialist with the necessary qualifications for the time required to perform the specific work.

The program of the bureau, as outlined in one of the publications, is :

I. The establishment of a modern budget-making procedure.

2. The establishment of a training school for firemen in the fire department.

3. The immediate organization of a complete system of fire prevention inspection by the uniformed forces, and the obtaining of any provincial legislation necessary to render this inspection immediately effective. 
4. The making of a thorough study of the civil service of the city as a basis of recommendations looking towards the establishment of standard grades of work, and corresponding rates of remuneration, the elimination of duplication of work, the abolition of unnecessary positions, the creation of necessary positions, increasing the rates of pay for underpaid work, and decreasing the rates of pay for relatively overpaid work. In general, the setting up of adequate civil service regulation and control in all departments of the city.

5. The informal constitution of an administrative board made up of the heads of city departments, meeting weekly or bi-weekly with the Mayor as chairman, the city clerk being secretary. In the absence of provincial legislation this informal committee could only meet for purposes of discussion, interdepartmental coöperation, and the formulation of policies to be referred to the board of control and city council. The minutes of the meetings of the administrative board should be published with the minutes of the council and board of control.

6. A thorough study of the assessment methods of the city with special reference to (a) business assessments, (b) assessment of improvements, (c) local improvement assessments, (d) equalization of assessments and (e) appropriations.

7. The providing of the city auditor's department with the necessary staff to strengthen the auditing control of the city's expenditures.

8. The provision of the necessary facilities for an energetic following up of the city's report on centralized accounting control and uniform departmental accounting to strengthen administrative control of the city's expenditures.

9. A thorough study of the educational resources and needs of the city.

Since its establishment in 1914, the bureau has assisted in the establishment of the scientific form of budget for the city. It has studied the accounting and estimate-making of two organization units of the city government, and has made recommendations concerning them. It has interested itself in the reorganization of the Fire Department; made a field survey of the City Street Cleaning and Garbage Disposal 
Service; conducted a help-your-city campaign; studied recreation facilities of the city, and wage conditions; has made inquiries into school problems; and has made studies of the assessments and of the Toronto city organization.

The bureau maintains a reference library in which copies of all completed working papers of every study made by the bureau are carefully preserved. It maintains a reference library of books, reports, and monographs, without duplicating unnecessarily the material on the shelves of the public library. This library and reference service are open to the public, and a desk is kept free for such use. The bureau has also responded to many requests for speakers on civic topics.

The bureau's publications are issued in the form of pamphlets containing reports of important investigations and studies, folders and pamphlets known as White Papers, and occasional folders known as Bulletins, which contain brief statements of information of current interest.

\section{PUBLICATIONS}

Annual report, Ist-4th, I9I5-19I8. Toronto, 1915Report year ends Feb. 28.

Citizen control of the citizen's business. White paper, No. I $(3,6$, I3-16, I8-19). Toronto, I9I5-

Effective citizen coöperation. Bulletin No. I (65). March 6, I9I4(Jan. 29, 1918). Toronto, 1914-

Toronto's budget for 1915, I916, 1917. Toronto, 1915-1917. (3) v.

The citizen and the city's business. Toronto, Ontario press limited, n.d. 7 p.

Why a Bureau of municipal research was needed two years ago. Why it is needed this year. Why it will be needed twenty years from now. Toronto, n.d. cover title, I6 p.

Administrative study of the Toronto Department of public health as of March Ist, I9I5, by the Bureau of municipal research, Toronto, Ont. . . . [Toronto, I9I5] 53 p. illus., port., diagrs.

Reprinted from The Public health journal, issues of July, Aurgust, September and October, 1915.

Health survey. Report of administrative study of the Health department. November, I9I5.

An analysis of Toronto's budget for 1917 , based upon the official estimates, rearranged by the Bureau of municipal research so as to show costs of services rendered and of things purchased. Toronto, I917. 24 p. illus.

Can a community plan its giving for community purposes, or must individuals continue to give without a knowledge of the community's needs and what resources exist to meet these needs? A 


\section{EFFORTS FOR ADMINISTRATIVE REFORM}

discussion of haphazard versus planned philanthropy based on a study of the facts. Toronto, Issued by the Toronto Bureau of municipal research, I9I7. 47, [I] p. incl. illus., diagrs., forms. Report on the schools of Akron, made for the Education committee of the Akron chamber of commerce, by Horace L. Brittain, director of the Toronto Bureau of municipal research ... [Akron, r9r7] 234 p. illus.

\section{Denver, Colo.: Civic and Legislative Bureau of the Den-} ver Civic and Commercial Association. The Civic and Legislative Bureau of the Denver Civic and Commercial Association of Denver, Colorado, created in 19I6, is the successor in its activities of the Colorado Taxpayers Protective League which was established in I9I4. The bureau is presided over by a chairman and a secretary, the latter being a paid officer. The present secretary is also secretary of the Survey Committee of State Affairs of Colorado.

The first important work undertaken by the Colorado Taxpayers Protective League, soon after its creation, had been the employment in I9I4 of the Bureau of Municipal Research of New York City to make a survey of certain departments of the city and county of Denver. This survey covered the Departments of Social Welfare, Safety, Property, Improvements, Finance, and Accounts and Auditing; the budget, indebtedness, the Civil Service Commission, the offices of the jury commissioner, of the election commission and of the public administrator, and the Juvenile Court. A critical examination was also made of the Denver charter. The report of the survey contains criticisms of organization, methods and conditions as found, and constructive suggestions.

Much attention was also given by the league to the subject of a budget for Denver; and monthly general balance sheets and other financial statements for each of the last six months of I9I5 as well as budget estimates for I9I6 were prepared and issued.

In 1916, a school survey committee consisting of one representative each of the Denver Board of Education, and the Colorado Taxpayers Protective League, made an extensive survey of the Denver public schools. The services of special experts were engaged, and reports made on the general organization and management and the work of the schools, vo- 
cational education, and the business management, school buildings and grounds and health work in the schools. Following this survey, a special committee was appointed by the Civic and Legislative Bureau in collaboration with educators, school officials and business men, which drew up a tentative outline of a proposed educational code for the state of Colorado.

During the same year the Institute for Public Service of New York City made a field survey of the Denver Federation for Charity and Philanthropy for the Colorado Taxpayers Protective League at the request of the federation. The survey covered twenty-six charitable agencies represented in the federation. A long list of constructive suggestions was presented in the report of the survey, and at a general meeting of the officers and trustees of all the institutions conprising the federation a resolution was unanimously adopted pledging the separate institutions "to unite their efforts in cooperating for the purpose of carrying out the plans and recommendations of this report as rapidly as possible."

On January II, I9I7, the bureau began to issue, as a supplement to the weekly issue of The Commercial, the organ of the parent association, a Legislative Index for the use of members of the legislature and the public generally which contains notations of the progress each week of all bills before the legislature and other information of interest in connection with the progress of legislation that is pending or has been enacted.

The bureau is supplying field work for students of the Denver University. A number of these students have been engaged upon the school code draft and other work, for which they obtain credits in their university courses. Students have also been stationed in the state legislature for the purpose of recording the progress of every bill and resolution in that body, this information being used for the Legislative Index.

Following is a list of the publications of the Colorado Taxpayers Protective League and the Civic and Legislative Bureau of the Denver Civic and Commercial Association and of reports made under their auspices and with their coöperation. 


\section{EFFORTS FOR ADMINISTRATIVE REFORM}

\section{PUBLICATIONS OF THE COLORADO TAXPAYERS PROTECTIVE LEAGUE}

Denver-budget estimates for I9I6. November, I9I5. 84 p.

Denver-general balance sheet and other financial statements, July, I9I5-Dec., I9I5. $6 \mathrm{v}$.

Procedure for the office of the Commissioner of supplies. n.d. I7 p.

Standard classification of accounts for the use of the city and county of Denver, with explanatory statements and ready reference index. By Thomas R. Lill for the Colorado taxpayers protective league. Denver, I9I5. $57 \mathrm{p}$.

Denver federation for charity and philanthropy. Summary report of field survey for the Colorado taxpayers protective league . . . Denver, I9r6. 30 [2] $\mathrm{p}$.

Uniform system of accounts for ... Denver, I9r6. 8I p.

City and county of Denver; report on a survey of certain departments ... prepared for the Colorado taxpayers protective league, by the Bureau of municipal research, New York, I9I4. [Denver, I914?] 583 p. plates, fold. plan, fold. diagrs.

PUBLICATIONS OF THE CIVIC AND LEgISLATIVE BUREAU OF THE DENVER CIVIC AND COMMERCIAL ASSOCIATION

Tentative outline of proposed educational code for the state of Colorado, (revised to December I, I9I6) ... [Denver, I9I7?] $30 \mathrm{p}$.

A proposed educational code for Colorado, prepared by committee appointed under the Civic and legislative bureau of the Denver civic and commercial association in collaboration with educators, school officials and business men from all parts of Colorado; and based upon the most progressive educational organization and legislation in other states viewed in the light of Colorado's needs. [Denver] I9I7. 90 [2] p.

Legislative index of the twenty-first General assembly. Prepared under the direction of the Civic and legislative bureau. Jan. II, I9I7-

Supplement to The Commercial, the weekly publication of the Denver civic and commercial association.

Rochester, N. Y.: Bureau of Municipal Research. The Rochester Bureau of Municipal Research was incorporated April 20, I9I5. The governing body is a board of eleven trustees of which the president of the Rochester Chamber of Commerce is ex-officio a member. The executive head of the bureau is the director who is also the secretary of the corporation.

The purposes for which the corporation was formed, as expressed in the certificate of incorporation, are:

I. To serve the City of Rochester, New York, as a nonpartisan and scientific agency of citizen inquiry; to promote 
efficient and economical municipal government, scientific methods of accounting and of reporting the details of municipal business in said city, with a view to facilitating the work of public officials; and for the above purposes, to collect, classify, analyze, correlate, and interpret facts as to the administration of municipal government, and to make such information available to public officials and citizens, in order that inefficient methods of administration may be eliminated and efficient methods introduced and encouraged; and to promote the development of a constructive program for the said City of Rochester that shall be based upon adequate knowledge and consideration of community needs.

2. To do all and everything necessary, suitable and proper for the accomplishment of any of the purposes or the attainment of any of the objects or the furtherance of any of the powers herein set forth, provided that the same are not inconsistent with the laws under which the corporation is organized.

The activities of the bureau have been two-fold, namely, coöperating with public officials in securing greater efficiency, and informing the public of what the government is doing, how it is being done and what it costs.

Among the first of the bureau's activities was an arrangement with the New York Bureau of Municipal Research whereby the latter made a general study of the local city and county governments, resulting in the publication of an elaborate report of a general survey of the government of the city of Rochester with critical appraisal and constructive suggestions, and reports describing the organization and functions of the city of Rochester and of the county of Monroe.

Studies were made of the Street Cleaning Service, the Department of Public Works and the Department of Charities, and on the inspection of asphalt repairs, and reports were submitted to the commissioner of public works proposing reorganization of these services; likewise studies were made and reports submitted to the mayor concerning the safety conditions of the Convention Hall gallery, the methods of letting contracts for local improvements, the collection and disposal of garbage, and the proposed specifications for fire hose for the city of Rochester. A study was also made of the 


\section{EFFORTS FOR ADMINISTRATIVE REFORM}

Engineering Department and a report submitted to the city engineer.

The bureau has coöperated since its beginning with the city comptroller, and while it has made no formal reports or written recommendations concerning city accounting, such matters were informally discussed with the comptroller. In this way the bureau assisted the comptroller in the preparation of the 1916 budget and in the arrangement of a rather elaborate classification of objects of expenditures, which was published in May, I9I6.

Most of the work done by the bureau resulted in the preparation of reports which were not published but submitted in manuscript form to the city officials concerned. Following is a list of the publications and manuscript reports which have been issued either by or through the instrumentality of the bureau.

\section{PUBLICATIONS}

Government of Monroe County, N. Y. (including town government), description of organization and functions, transmitted to the New York state constitutional convention by the New York state constitutional convention commission, prepared for the Rochester bureau of municipal research, by the New York bureau of municipal research, I9r 5. [Albany, J. B. Lyon company, printers, I915.] 60 p. fold. diagrs.

(In New York state constitutional convention commission. City and county government. [No. 3] Albany, I9I 5.)

Government of the city of Rochester, N. Y., description of organization and functions, transmitted to the New York state constitutional convention by the New York state constitutional convention commission, prepared for the Rochester bureau of municipal research, by the New York bureau of municipal research, 1915. Albany, J. B. Lyon company, printers, I9I5. I04 p. fold. diagrs.

(In New York state constitutional convention commission. City and county government. [No. 2] Albany, 1915.)

Government of the city of Rochester, N. Y. General survey, critical appraisal and constructive suggestions, prepared for the Rochester bureau of municipal research, by the New York bureau of municipal research, May-July, 1915. [Rochester? 1915?] 2 p. 1., 546 p. plates, plan, fold. tab., diagrs.

Average costs of asphalt pavements. I9r6. fold. table.

Average costs of brick pavements. I916. fold. table.

The purposes and organization of the Rochester bureau of municipal research, inc. Rochester, N. Y., Democrat and chronicle print. [1916] $20 \mathrm{p}$.

Proposed specifications for fire hose in the city of Rochester and 262 


\section{AGENCIES OF PARTICULAR CITIES: UNOFFICIAL}

report thereon; submitted to the mayor, to the commissioner of public safety and to the Board of contract and supply. [Rochester] Rochester Bureau of municipal research, inc. [19I7] 22 p., I 1. incl. tab.

Report on the problem of snow removal in the city of Rochester,

N. Y. . . Rochester, 19I7. 44 p. pl., charts.

Abstract of a report on the Department of charities of the city of Rochester, N. Y. Rochester, Rochester bureau of municipal research, inc., I9I8. 37 p.

\section{San Francisco, Cal.: Bureau of Government Research.} In April, I9I6, the San Francisco Real Estate Board, as a result of the rapidly rising taxes in that city, appointed a tax committee. The first work undertaken by this committee was the examination of the I9I6-I7 budget estimates which had been transmitted to the finance committee of the Board of Supervisors. The committèe found, however, that the field of its work was so broad and the problem so complex that a staff of trained experts was needed to accomplish the desired results. It was, therefore, decided to raise a fund to finance a general survey of the city and county government. In less than six weeks a fund of over \$I I,O0O was subscribed in \$100 subscriptions.

With this fund available, the Bureau of Municipal Research in New York City was employed to make an unbiased, analytical and constructive survey of the principal departments of the city government, $\$ 8,500$ being set aside for this purpose. This survey was begun early in June, 1916, and the report submitted in September. The results were published in a volume of over seven hundred pages entitled, The Government of the City and County of San Francisco Survey Report.

In order that the program which the survey inaugurated might be followed up it was decided to organize a local bureau of research in San Francisco, and on October 19, I9I6, the new organization was incorporated under the title, "San Francisco Bureau of Government Research."

The bureau is declared to be "an incorporated, non-partisan citizens' agency to study public business, coöperate with officials and specifically work for economy and efficiency in municipal affairs." It is financed for five years with an annual income of $\$ 20,000$. 


\section{EFFORTS FOR ADMINISTRATIVE REFORM}

The present governing body is a board of ten trustees including the chairman, vice-chairman, treasurer and secretary. All officers, including the director, are elected by the trustees. The constitution, however, provides for sixteen trustees. The director is the paid executive of the bureau. The present director participated in the above mentioned survey as an expert of the New York Bureau of Municipal Research. He is assisted by a staff of five experts. There is also an executive committee appointed by the chairman with the approval of the trustees.

Membership in the organization may be obtained by a two-thirds vote of the board of trustees or by a two-thirds vote of the existing members of the association, but no person holding a salaried position in the city or state government may be a member.

The functions of the burean, as defined in the constitution of the organization, are:

To act as an incorporated, non-political, non-profit-making citizens' agency for securing the highest obtainable degree of efficiency and economy in the transaction of public business, particularly in the municipality of San Francisco, through investigating, collecting, classifying, studying and interpreting facts concerning the powers, duties, actions, limitations and problems of the several departments of government, and making such information available to public officials and citizens, and promoting the development of a constructive program for the City of San Francisco that shall be based upon adequate knowledge and consideration of community needs, thereby encouraging economy in the conduct of public business in order that the taxpayers may be assured full return value in services rendered for taxes paid and money spent in governmental cost payments; and further, to do any and all lawful things that may be necessary for or conducive toward the attainment of any and all of the objects and ends hereinbefore expressed.

The bureau upon its organization took over the active work of the tax committee of the San Francisco Real Estate Board, although the latter continued to exist. The activities of the bureau during the year of its existence have been very largely in the field of finance, and promoting the adoption of 
improved forms of estimates and better budgetary procedure. Since February 2I, I9I7, the bureau issues a bi-weekly folder entitled, The City.

\section{PUBLICATIONS}

The City ... No. I(10), Feb. 21, I9I7 (Sept. 5, 1917). San Francisco, rgi7-

Uniform classification of expenditures for use in preparing 1917-18 budget estimates, together with revised budget estimate forms and instructions for their use, by Klink, Bean \& Co. [with the coöperation of the Bureau].

Detroit, Mich.: Bureau of Governmental Research. The Detroit Bureau of Governmental Research was incorporated March 22, 1916, and began operations the following month. It is a private organization with a governing body of ten trustees who were its original incorporators and are responsible for its policies and financing. In order that the bureau may be assured freedom from partisan politics, it is provided in the by-laws that: "Every trustee who shall hold office or be a candidate for public office or accept any public employment shall automatically cease to be such trustee."

The working force consists of a director and a staff of three experts, all of whom have had previous training in municipal research work.

The bureau has, an annual budget of $\$ 25,000$, the funds being raised by subscription.

The purpose of the bureau is declared to be "to secure efficiency and economy in government, whether national, state or municipal, by all lawful means other than promoting or defeating the election, or appointment to public office, or the employment of any person or persons in a public position." The bureau coöperates with persons in office by increasing efficiency and eliminating waste, and it serves as an independent non-partisan agency for keeping citizens informed about the city's business; and its director says that "it proposes to deal with the matter of securing clean, well paved streets, adequate sewers, a low death rate, reduced sickness, proper disposal of refuse, efficient police and fire protection, centralized purchasing, standardized supplies, reasonable salaries, equitable assessments, and the thoughtful expenditure of public funds." 


\section{EFFORTS FOR ADMINISTRATIVE REFORM}

While the bureau has existed but a short time, it has made an extensive survey of the Sewer Department of Detroit, and has issued a report on the same with criticisms and recommendations regarding existing conditions, all of which have been taken up favorably by the commissioner of public works. It has also made an intensive study of the organization and administration of the local school board, with the full cooperation of all its members; an intensive study of the city's financial methods, with the end in view of systematizing accounting and budget procedure; and a report on the status of the work of separation of grade crossings in the city of Detroit, the purpose of which was to summarize briefly the present status of the work of separating the grade crossings of the streets and steam railways of the city of Detroit, and to suggest measures which, if adopted, will secure a more rapid transaction of this work, and at the same time will make possible adequate protection of the interests of the city.

At the instance of the Detroit bureau the New York Bureau of Municipal Research made a report on the Department of Buildings of the City of Detroit. This report is a statement made by the New York bureau to suggest lines of further study.

The bureau has undertaken to furnish constant, reliable and unbiased information to the public' so that when the people of Detroit consider the municipal, county and state governments and discuss their merits or demerits, they may have access to these facts.

PUBLICATIONS

Report on city budget. I9I6.

The Detroit bureau of governmental research ... [Prospectus] May, 1916. Detroit, I9I6. $8 \mathrm{p}$.

The citizen and the city government ... July, 1917. Detroit, 1917. II $\mathrm{p}$.

A year of municipal progress. An inventory July I, 1916, to June 30, I917. Detroit, Mich. $15 \mathrm{p}$.

The public's business .... No. I-16. March 23, 1917-Detroit, 1917A bulletin in folder form issued at irregular intervals.

Toledo, Ohio: Public Research Bureau, Toledo Commerce Club. In May, I9I5, the Toledo Commerce Club appointed a committee under the name of Public Efficiency and Econ- 


\section{AGENCIES OF PARTICULAR CITIES: UNOFFICIAL}

omy Committee, to concern itself with matters of municipal administration. This committee employed the Ohio Institute for Public Efficiency to make a thorough study of the financial status and governmental organization of Toledo. The committee coöperated, through the institute, with the Bureaus of Municipal Research of Columbus and Akron, in working out, with the State Bureau of Inspection and Supervision of Public Offices, a new system of accounting for the cities of Ohio. This system was adopted by the Toledo city government under its new charter which went into effect January I, 1916. In I9I6 the committee changed its name to the Public Research Committee, and gave the title of Public Research Bureau to the department of the Toledo Commerce Club handling its work. The director of the bureau in a letter to the author of the present work states that, since the change of name, the bureau has undertaken to work out a complete detailed analysis of the expenditures of the city in 1916. This was intended for use as a basis for budget making in 1917 and I9I8. The bureau has also undertaken an investigation of the cost of garbage collection.

The bureau has issued no publications of its own, but plans to use a part of the Commerce Club Newes, the organ of the Commerce Club, for the purpose of giving publicity to its work.

Yonkers, N. Y.: Bureau of Municipal Research. The Bureau of Municipal Research of Yonkers, New York, is a non-partisan incorporated citizens' organization, established in September, 1916. The governing body is a board of fifteen trustees, the officers being a president, a vice-president, a treasurer and a secretary. The latter is the paid executive head of the bureau. The bureau is entirely supported by voluntary contributions, its estimated cost of operation being about $\$ 5,000$ per annum.

The purposes of the bureau as set forth in its charter are:

(a) To promote efficient and economical municipal government; to promote the adoption of scientific methods of accounting and of reporting the details of municipal business, with a view to facilitating the work of public officials; to secure 


\section{EFFORTS FOR ADMINISTRATIVE REFORM}

constructive publicity in matters pertaining to municipal problems; and to these ends to collect, to classify, to analyze, to correlate, to interpret, and to publish facts as to the administration of municipal government.

(b) To do all and everything necessary, suitable and proper for the accomplishment of any of the purposes or the attainment of any of the objects or the furtherance of any of the powers herein set forth, provided the same be not inconsistent with the laws under which this corporation is organized.

(c) In securing the attainment of the above purposes, an effort will be made to coöperate with such public officials of the city as desire to utilize the data, investigations and reports of the Bureau.

Immediately upon its organization the bureau began a study of the accounting system of the city and as a result recommended improved methods of preparing the city budget. These recommendations have been adopted by the Common Council and the Board of Estimate and Apportionment, and forms and instructions prepared by the bureau have been issued by the mayor to put them into effect. By this means detailed information has been given to city officials for the consideration of the budget, and departmental requisitions have been presented in November instead of, as in some cases, as late as March.

The next study was with reference to the cost of laying water-mains, a subject over which there had been some controversy. The work had been done by the city through the employment of day labor. The bureau found that by laying the water-mains by contract, work for which the city paid approximately $\$ 100,000$ could have been done for $\$ 20,000$. Since the issue of this report no extensions of water-mains by day labor, chargeable to the city, have been authorized by the Common Council.

Another study was of the salaries of city employees in Yonkers and a comparison with those in other cities. The bureau found that Yonkers is paying more for certain services than it should pay, and recommended that all proposed salary increases be carefully considered, and that no increases 


\section{AGENCIES OF PARTICULAR CITIES: UNOFFICIAL}

he made unless it is shown to the Board of Estimates that the services performed will be worth the increased rate.

Numerous informal suggestions have been made to various city departments regarding the details of administrative procedure.

All the reports issued by the bureau have appeared in printed form. They are as follows:

\section{PUBLICATIONS}

Report No. I-Yonkers, 1916Contents.

No. [1] Suggested improvements in the budget methods of the city of Yonkers. I9I6. 8 p.

No. 2. The cost of laying water-mains by the city of Yonkers. I9I6. 8 p.

No. 3. Comparisons of the salaries of city employecs in Yonkers and other cities. I9I7. $4 \mathrm{p}$.

No. 4. What will the I9I7 budget be? I9I7. 8 p.

No. 5. Suggested improvements in the audit of claims by the Comptroller's office. I9I7. 8 p.

No. 6. Suggested improvements in the collection of revenue. 1917. 8 p.

No. 7. The purchase of fire department equipment in Yonkers. I917. 8 p.

No. 8. Memorandum to the Common council, the Board of estimate and the public on the proposed extension of the water supply system. I9I7. I8 p.

No. 9. Financial facts which should be of interest to the citizens of Yonkers. 19I8. 24 p.

City of Yonkers, New York. Directions for preparing the budget. Prepared by the Yonkers bureau of municipal research. I2 p.

To the taxpayers and others interested in the welfare of the city of

Yonkers. The Yonkers bureau of municipal research, inc. The reason for its formation, its purposes, plan and scope ... Yonkers 「1916] [2] p.

What should the next mayor of Yonkers do?... October, I9I7. Yonkers, I9I7. $8 \mathrm{p}$.

Indianapolis, Ind.: Bureau of Governmental Research of the Indianapolis Chamber of Commerce. In March, I9I8. announcement was made by the Chamber of Commerce of Indianapolis that it had created a Bureau of Governmental Research and had selected Mr. Robert S. Tracy of the Philadelphia Bureau of Municipal Research as its director. Regarding the work contemplated for this bureau the announcement said : 


\section{EFFORTS FOR ADMINISTRATIVE REFORM}

One of the first tasks Mr. Tracy will have to take up as head of the new Burean of Municipal Research will be to create and develop a muncipal, statistical and information bureau, in order that all city officials may have access to the latest, most comprehensive information available about their own work, and city problems in general.

Sufficient money has been appropriated by the Board of Directors, for this Bureau, to enable Mr. Tracy to call in experts in various lines of municipal endeavor to assist him in solving city problems calling for special consideration.

Mr. Tracy's work will be that of helpful coöperation with city officials, and it is hoped and believed that the work this Bureau can give will be of material assistance to the city administration in giving to Indianapolis a government that will be as effective as any to be found in the United States.

Columbus, Ohio: Bureau of Municipal Research. In the spring of I9I5 a Bureau of Municipal Research was created at Columbus, Ohio, for the purpose of undertaking certain investigations preliminary to the inauguration of the new city charter. When these investigations were completed it was not found feasible to continue the work of the bureau permanently and the trustees, therefore, disbanded in the winter of I9I6. The bureau never employed a staff of its own but conducted all of its work through the staff of the Ohio Institute for Public Efficiency. All of its reports are listed among the reports of the latter institution.

Memphis, Tenn. : Bureau of Municipal Research. A Bureau of Municipal Research was created in Memphis, Tennessee, in 1909, but only continued in operation for a short time, being abolished in I9IO or I9II. During this time it prepared and published the following reports:

\section{PUBLICATIONS}

Memphis: a critical study of some phases of its municipal government with constructive suggestions for betterment in organization and administrative methods. Bureau of Municipal Research, Memphis, October, 1909. (Memphis, Press of S. C. Toof \& Co., 1909.) 202 p. tables (partly fold).

Budget, city of Memphis, I9Io. Prepared for the Memphis Bureau of Municipal Research ... (Memphis, E. H. Clarke and Bro. I9IO?) 25 p. I 1 . 


\section{AGENCIES OF PARTICULAR CITIES: UNOFFICIAL'}

Story of the Memphis Bureau of Municipal Research. May, I9Io. (Memphis, S. C. Toof \& Co., I910.) 16 p.

Petersburg, Va.: Bureau of Governmental Research. In I9I7 a Bureau of Governmental Research was established in Petersburg, Virginia. Due to lack of financial support and other reasons it does not appear that much work was accomplished by it. Its only publication is the one listed below.

\section{PUBLICATION}

Bulletin, No. I-July 16, 1917-Petersburg, Va., 1917Contents :

No. I. Graphic argument for city manager government, by Leroy Hodges. 1917. (folder) 


\section{CHAPTER IX}

\section{AGENCIES TO INVESTIGATE THE ADMINISTRA- TION OF PARTICULAR COUNTIES : UNOFFICIAL}

There are no official and but few unofficial agencies for research in county government. This is due to the fact that the operations of few counties are on a sufficient scale to warrant the maintenance of a special agency for the investigation of their organization and methods of business. This is not saying that it is not extremely desirable that the work of these bodies should not be subjected to scientifie study. Any one who has had any familiarity with the conduct of county affairs in the United States knows how great is the room for improvement in their organization and methods of business. In view of the fact that the form of organization and in general the scope of the work of all counties in a state are so nearly identical, it would seem that a study of their administration could most effectively be made by a body having state-wide powers. Notwithstanding this, special county research agencies have been established in the few cases described below.

Westchester County, N. Y.: Research Bureau. In I9Io something over one hundred citizens and taxpayers of Westchester County, New York, established what is known as the Westchester County Research Bureau with the objects as stated in the report of its director:

I. To Promote Efficient, Economical Government:

1. By the collection and presentation of exact information concerning the details of administration.

2. By coöperation with the administrative authorities in efforts to improve the public service. 


\section{AGENCIES OF COUNTIES: UNOFFICIAL}

3. By demonstrating to such authorities the use and advantage of

(I) Standardized records of public business.

(2) Standardized purchase and distribution of supplies.

(3) Standardized units of public service and of remuneration therefor.

(4) In general, standardized methods of conducting public business.

II. To Promote the Adoption of Scientific Methods of Accounting:

I. For the county.

2. For the cities, where such methods are not already in use.

3. For each village-a uniform system for the county.

4. For each township-a uniform system for the county.

III. To Secure Full Publicity of the Details of Public

- Business Through Complete and Scientific Reports:

I. As to the condition of the public estate.

2. As to the efficiency of the public employees.

3. As to the cost, to the taxpayer, of any department, function, particular operation, or detail of county or local municipal administration.

IV. To Prevent Loss of Lives or of Health from Preventable Diseases:

I. By showing the exact statistics of such losses.

2. By demonstrating the economic loss to the communities from such causes.

3. By coöperation with health authorities to secure such sanitation and correct health administration as to prevent such losses.

V. To Devise Remedial Measures for Faults Clearly Revealed.

VI. To Promote Efficient and Economical School Administration and to Secure Full Publicity for School Work and Achievements :

I. As regards the sanitary conditions of the schools and their equipment, and sanitary inspection of pupils.

2. As to compliance with the Education Law, and as to the character of such law.

3. As to the retardation or advancement of pupils. 
4. As to the elimination or continuation of pupils.

5. As to economy in financial outlay.

VII. To Supply Exact, Full, Verifiable Information and Data to Agencies Organized for the Betterment of Civic Conditions in any Legitimate and Wholesome Way.

The bureau is incorporated as a non-stock membership corporation. Its officers are a president, a vice-president, a treasurer, a secretary and seven directors. The secretary is the only paid officer. Among the results accomplished by the bureau the following may be enumerated:

In I9I I it published the results of a study of the conditions governing the collecting of taxes in Westchester County, the methods employed in making such collections and the resultant cost to the taxpayers. The report also contained suggestions for changes in the law intended to increase the efficiency and reduce the cost of tax administration. This report has been an important factor in bringing about a better tax law, which it is alleged saves the county about $\$ 50,000$ per year.

In 1912 the bureau published two bulletins on budget making, namely, a comparison of county budgets for a period of five years and pointing out what a budget should reveal, and a report on Making the County Budget, which was designed to show how a scientific budget may be prepared, the form in which it may be made public, and the methods by which the opinions of the people may be placed before the Board of Supervisors for its guidance in the adoption of its annual program of community service.

This report it is claimed resulted in the adoption of a better budget system, effecting a saving estimated at about $\$$ I25,ooo per year.

In I9I2 a study was made of "the purchase of county supplies and the audit of county claims." The report of this study was made to the Board of County Supervisors of Westchester County and pointed out the wastefulness of the present system. This resulted in the establishment of a new purchasing department which it is stated effected an estimated saving of about $\$ 10,000$ per year. 


\section{AGENCIES OF COUNTIES: UNOFFICIAL}

In 19I4 certain facts were prepared by the bureau concerning the county printing expenses, which were presented as evidence before the Grand Jury. As a result of the subsequent action of the Grand Jury the special laws on public printing were repealed resulting in an estimated saving of $\$ 25,000$ per year to the county.

As a further result of the bureau's activities, the office of county comptroller was created, and this officer, it is estimated, saves the county about $\$ 30,000$ per year.

A more recent report of the bureau (September I, 1916) deals with the IVestchester County Building Commission and its work and points out the advantage of the present system, that is, a commission of three members as compared with the work as formerly handled by the larger board of supervisors.

Many local investigations have led to better methods and economies. Such studies have been made in eight localities in the county.

The bureau has been called upon from time to time to coöperate in the preparation of schedules for investigation by various committees and to aid fiscal officers of some of the municipal corporations of the county in the installation of modern accounting systems and the improvement of existing methods.

The bureau has made many recommendations to the heads of departments of county and local governments, both as to the location and elimination of governmental waste, and as to the establishment of efficiency and the installation of scientific methods. Many of its recommendations have been adopted. It has aimed whenever possible to criticise not work but methods, and has endeavored never to find fault without providing a constructive remedy. It has endeavored to place at the service of officials the work of skilled experts, and its guiding principle has been to coöperate with organized government.

\section{PUBLICATIONS}

The Westchester County research bureau ...「rgı [4] p.

Method and cost of collecting taxes in Westchester County. IgII. 7I p. [Document on county government collected by the $\mathrm{Na}$ tional short ballot organization.]

The purchase of county supplies and the audit of county claims. 


\section{EFFORTS FOR ADMINISTRATIVE REFORM}

Report made to the Board of supervisors of Westchester county ... I9I2. I6 p.

Efficiency series, Bulletin No. I-I9I2(?)-

Contents.

No. 2. Making the county budget. I9I2. $20 \mathrm{p}$.

A brief report on the organization, activities, and achievements of the Westchester County research bureau, I9Io-I9I3. [I9I4] I5 p. County printing expenses... I9I4. 23 p.

The Westchester County research bureau. A record of service and an extraordinary opportunity. I9I5? $8 \mathrm{p}$.

The Westchester County research bureau. What is its work? For whom does it work? Why is it needed? I916 (folder).

Westchester County building commission. Report of its work as at September I, I9I6.

Alameda County, Cal. Tax Association. The Tax Association of Alameda County is an association of taxpayers of Oakland, Alameda, Berkeley, Piedmont, Emeryville, Niles, San Leandro and Livermore, in Alameda County, California, the object of which is declared to be: "To correct existing evils and inequalities in taxation; promote economy in public expenditures, both state and local; and to formulate and announce the most progressive economic thought and administrative experience available for the correct guidance of public opinion, legislative and administrative action on all questions pertaining to state and local taxation."

Its governing body consists of its officers and an executive committee of twenty-two members, with standing committees on law, campaign, finance and organization and membership.

Among the recent activities reported by the association are: A survey of the organization, business management, revenues and expenditures of the school department of Oakland; and a survey of the auditor's office of Oakland with reference to its operation under a new accounting system recently installed on its recommendation. The association is now engaged in an effort to secure the adoption of a proposed charter under which the cities of the county may federate, and under which it is expected that unnecessary duplicating of officials may be eliminated and the people provided with better and more service at a lower cost. The system contemplates a system of boroughs whereby each city retains its present identity and independence, fixes its own tax rates and also controls borough expenditures. An idea of the other activi- 


\section{AGENCIES OF COUNTIES: UNOFFICIAL}

ties of the association may be obtained from an examination of the appended list of its publications.

\section{PUBLICATIONS}

Bulletin No. I-8. Oakland, I9I I-I9r3.

No. I. Organization and objects of tax association.

No. 2. Office of county recorder.

No. 3. Emergency hospital and detention home and care of indigents.

No. 4. County infirmary and infirmary hospital.

No. 5. Registration as conducted by the County clerk of Alameda County.

No. 6. Analysis of recall petition. Standardizing the accounting system.

No. 7. Suggestions for consideration in preparing a charter for Alameda County.

No. 8. Coroner's Office; and the creation of an extra department of the Supreme Court.

Continued by its Report No. 9-

No. 9. The Alameda County plan.

No. ro. Section A. Cost of elections in rgro.

Section B. Cost of elections in r 912 .

Section C. Cost of city elections.

No. II. The Municipal auditorium of the City of Oakland, Cal.

No. 12. Efficiency in municipal and county government.

No. I3. Central purchasing agency for Alameda County and its cities.

No. I4. Facts which justify the existence of the Tax Assosociation.

No. I5. How the supervisors and the Tax association saved $\$ 36,310.85$ on the I9I4 primary.

No. I6. Increasing per capita cost of state, county and municipal government.

No. 17. Not printed (?)

No. I8. Summary of proposed amendments to Oakland charter.

No. 19. School department of Oakland.

No. 20. Survey of the auditor's office, city of Oakland.

No. 2I. Some of the benefits that would accrue under a city and county charter.

No. 22. Sharpening the instruments of government. (A plea for the appointment of a general manager for public business.)

No. 23. Clipping the wings of extravagance. (A tabular statement of the cost of a special election in each county of California, illustrating savings effected through efficiency.)

No. 24. As others see us.

Tax association bulletin Jan., I9I3, No. I-Oakland, I9I3.

Centralized government for Alameda County and its cities. 


\section{EFFORTS FOR ADMINISTRATIVE REFORM}

City and county-centralized government for Alameda County and its cities. 1916. Io p.

City and county-summary of a charter for a federated city and county government for Alameda County and its cities. Igr6. $20 \mathrm{p}$.

City and county-organization chart-city and county government set up. I p.

Hudson County, N. J.: Citizens Federation. The Citizens Federation of Hudson County is an organization of citizens, taxpayers and business men of Hudson County, New Jersey. It is supported by the dues of its members. Its governing body is a board of twenty-five trustees.

The objects of the federation as shown in a printed statement are: "To examine into public affairs and the conduct of officials throughout the County, making known the result of such examinations when deemed necessary for the public good; to endeavor to the extent of its power to effect the betterment of governmental conditions throughout the County by cooperation with officials or otherwise; to promote and endeavor to secure the selection of properly qualified individuals as public officials; to aid in the prosecution of officials and others taking part in frauds upon the public, and to urge the enactment of laws which shall prevent fraud and tend to economical, simple and efficient administration; to endeavor to secure equal taxation upon the basis of the true value of ratables: to urge needed public improvements when the financial condition of the County warrants the same; and to watch legislation whereby anything inimical to the objects above expressed may be defeated, and to suggest and aid in the securing of such legislation as will best promote such objects."

\section{PUBLICATIONS}

[Circular] ... October, I9I2. [Jersey City? I912] [8] p.

Comparisons of appropriations and salaries . . January, 19i3. 24 p. diagrs.

Citizens bulletin. [Jersey City, 19-]

Issued monthly. No. 6, July 25 , 1913, issued by Jersey City committee, Citizens federation of Hudson County. 
PART II

ORGANS OF CENTRAL ADMINISTRATIVE CONTROL 



\section{PART II}

\section{ORGANS OF CENTRAL ADMINISTRATIVE CONTROL}

In the preceding part we have considered the work of official bodies which have been created by the national government and by various states and cities for the purpose of investigating governmental conditions with a view to formulating recommendations for "their improvement. The distinguishing feature of these bodies is the fact that they have had only investigatory and recommendatory powers. It is now our purpose to consider the organization and work of another class of official agencies which, while having for their end the same purpose as those already treated, namely, the improvement of methods of public administration, differ radically from these bodies in that, in addition to having large investigatory and recommendatory powers, they possess direct administrative authority of an important character.

In not a few of our governmental organizations there exists but little administrative authority for the accomplishment of major changes of organization and procedure. Statute, constitution, charter and ordinance render impotent the judgment of the chief executive authority. But even where these limitations do not exist and where the right of the executive to mold organization and procedure receives full recognition, there is seldom provided any specific organ through which the executive may effectively make use of his power. The need for such an organ is not satisfied by the creation of research agencies, having powers of recommendation only, of the type described in the preceding part of this volume. Useful as such agencies are, the necessity under which they labor, of appearing before the executive in the rôle of plaintiff with the department under investigation as defendant, and of overbearing the opposition which that department is so likely to 


\section{EFFORTS FOR ADMINISTRATIVE REFORM}

set up against any proposals for change, has been and must continue to be a serious limitation upon their effectiveness. Only by the creation of an agency possessing a status superior to that of the several departments, can the full possibilities of the central control over administration be realized. Such an agency must either itself have the legal power of giving effect to its own recommendations, or its moral position in the administration, so to speak, must be such that its recommendations have the effect of orders in the ordinary course of events. )

It goes without saying that the need for this type of organ of administrative control varies directly with the magnitude of the organization. The outstanding need for such an organ in the national government has been set forth in full in another place. ${ }^{1}$ Here there is given an account of the agencies which have already been created by some of the states and cities.

${ }^{1}$ Chapter II of The Problem of a National Budget, by W. F. Willoughby, published by the Institute for Government Research, I9I8. 


\section{CHAPTER X}

\section{ORGANS OF ADMINISTRATIVE CONTROL IN THE STATES}

The services and institutions for whose administration state governments are responsible fall into three main classes: (I) subordinate political divisions such as municipalities, counties and the like; (2) state institutions; that is, institutions of a charitable or educational character, which, while more or less under private management, yet receive large sums for their support from the public treasury and are subject to special laws; and (3) services proper of the state government.

For the administration of all three of these classes of institutions the state is responsible. For years, however, the states possessed no organs through which they might effectively exercise that direction, supervision and control over these institutions which was imperative if efficiency in operation was to be secured. One of the most encouraging features of the modern movement for improving methods of public administration is the extent to which this lack has, in recent years, been recognized and central organs of administrative control have been created by the states. These organs have been of three kinds, corresponding to the three classes of services and institutions mentioned. Special services have been created or existing state officers have been empowered to prescribe uniform systems of accounting and reporting and otherwise to exercise control over subordinate political subdivisions. Boards of control have been established to exercise a general direction, supervision and control over state charitable and other institutions. And, finally, central services have been created to exercise a general control and supervision over the administrative departments, properly speaking, of the state government. 


\section{EFFORTS FOR ADMINISTRATIVE REFORM}

The special character of the organs of the first two kinds does not bring them within the scope of the present work. The third, that of organs of general administration, represents, however, one of the most important examples of organized efforts for the improvement of methods of public administration with which we have to deal. These organs are variously designated. In California, the designation, "State Board of Control" is employed; but this should not lead to the confusion of this organ with similarly designated boards in other states having for their purpose the control of state institutions.

The movement for the establishment of state organs of this character is of very recent date, and is intimately related to the movement for budgetary reform. Experience has demonstrated that if an efficient budgetary system is to be established it is imperative that the state shall have a central organ for the performance of the work of receiving estimates, making investigations regarding the organization, work, methods and needs of the several services and institutions submitting them, and, on the basis of the information so obtained, of formulating the budget to be submitted by the Governor to the legislature. The two reforms of the establishment of a budget system and the creation of a central organ of general administration have thus had to go hand in hand. Due to this close relation between the two, the organization and work of organs of general administration have necessarily been treated at some length in the volume on The Movement for Budgetary Reform in the States, published by the Institute for Government Research. In the account of these organs that follows, we will, therefore, draw largely upon the data there presented.

California: State Board of Control. In his message to the legislature on January 8, I9I I, Governor Hiram Johnson, of California, called attention to the absence of any adequate means for the exercise of effective control over the manner in which the services and institutions of the state were being administered. Impressed by this showing the legislature, by an act approved April 3, I9I I, provided for the creation of 284 
a body known as State Board of Control that is in many respects the most important and interesting organ of general administration that has been established by any state. ${ }^{1}$

This act provides that the State Board of Control created? by it shall consist of three salaried members, to be appointed by the Governor and to hold office at his pleasure, who shall devote their entire time to the duties of their office. As defined by the act, the duties of this board are: (I) to examine annually and report upon the books of state hospitals, reformatories and other institutions, commissions, bureaus and offices of the state; (2) to visit all public institutions maintained in whole or in part by state appropriations, to ascertain their condition and needs, and to visit public buildings in course of construction to see that they are being erected in conformity with the provisions of law; (3) to scrutinize and report upon claims against the state; (4) to count the money in the state treasury at least once a month; (5) to supervise the issuance of bonds by local governing bodies of the state; (6) with consent of the Governor, to authorize the creation of deficiencies in appropriations made by law, in cases of actual necessity; ( 7 ) to exercise general "powers of supervision over all matters concerning the financial and business policies of the State," and when it deems proper, or at the instance of the Governor, to institute investigations into the same; (8) to approve contracts entered into by state officials or organs, which before being entered into must be submitted to it for approval.

In connection with and under the supervision of the Board of Control the act also provided for a Department of Public Accounting whose function is defined to be to "devise, install and supervise a uniform system of accounting and reporting for any and all officers or persons in this State permitted or charged by law with the keeping of public accounts and records, and the custody, control and handling of public money or its equivalent, to the end that there shall be obtained similar and comparable data for every public office and every public account of the same class, and that there shall be a general,

${ }^{1}$ California, Acts, I9I I, Ch. 349. 


\section{EFFORTS FOR ADMINISTRATIVE REFORM}

systematic and uniform check upon the receipt and disbursement of all public revenue."

This department, as well as the Board of Control, is granted adequate authority to take testimony, compel the production of papers, and other inquisitorial powers. The board is directed to report biennially to the legislature "a history of its transactions and investigations."

The important function of the board, thus established, in making possible the preparation of a proper budgetary document for submission by the Governor to the legislature is described in the volume entitled The Movement for Budgetary Reform in the States, and need not be here rehearsed. The following statement taken from that volume, regarding the general status and functions of the board, however, deserve quotation :

In its State Board of Control, created in I9I I, California has an organ, which, as stated by the Governor of the State, has plenary powers over the business and financial affairs of the State. It moreover has a status and personnel independent of, and, as regards the powers to prescribe methods of business procedure, superior to, the administrative or operating departments properly speaking. .. . This body thus constitutes an organ of general administration comparable in character to the British Treasury. Its function as an organ for preparing the budget to be submitted to the legislature is thus but an integral part of the general function as a service of overhead administration.

Testifying to the results obtained after six years of operation, the Governor in his 19I7 message said:

During the past six years,' California has demonstrated that public business can be conducted as honestly and as efficiently as private business. . . . It seems incredible now, that prior to I9II there had not been for many, many years a state audit; that there was no centralized control over the business conducted by the state, no mode of accurately determining the necessity and amount of appropriations, and no supervision which would preclude favoritism in bidding. ... The legislature of I9II, therefore, passed the law creating the State Board of Control and gave to that board 
plenary powers over the business and financial affairs of the state. . . Investigations at once were held by the board, and corruption and fraud in the business of the state uncovered. Ruthlessly the old methods were destroyed and the individuals who were guilty were removed from the service of the state. But the great work of the board was to systematize the business of California in such way that it might challenge comparison with the system in vogue in those great business concerns that are models of commercial enterprise. ... The old log-rolling methods, inefficiency, fraud, corruption and political control have been displaced by a budget system, a searching financial supervision, modern business methods, economy and efficiency. . . . The business of the State of California is now conducted upon approved modern lines and conducted as efficiently and as economically as any systematic and scientifically managed private enterprise.

The appended list of publications of the Board of Control sufficiently indicates the extent and character of its activities. In its biennial reports, the board, as directed by law, gives an account of the various investigations undertaken by it.

\section{PUBLICATIONS}

First biennial report of the State board of control of California covering period from Dec. 3, I9I0, to Dec. 6, I9I2. Sacramento, I913. $138 \mathrm{p}$.

Budget covering appropriations. I9I4. $57 \mathrm{p}$.

Classification instructions for making property returns on inventory forms. Nos. I, 2 and 3. Effective Dec. I, 1915. [Annual].

Financial statement of the government of the state of California for the sixty-seventh and sixty-eighth fiscal years (July I, I9I5, to June 30, 1917), showing all sources of state taxes and all appropriations and fixed charges for the support of the state government and its institutions... [Sacramento? I9I5?] 9 p.

Report of the State board of control covering appropriations needed by state departments and institutions for the sixty-fifth and sixty-sixth fiscal years [I9I3-I9I5] with supplemental recommendations ... Sacramento, I912. $43 \mathrm{p}$.

- for the sixty-seventh and sixty-eighth fiscal years [1915-1917]. Sacramento, I9I4. 5I p.

for the sixty-ninth and seventieth fiscal years [I9I7-I9I9]. Sacramento, 1916. $63 \mathrm{p}$.

Pamphlet of procedure governing the preparation and presentation of estimates and the presentation and audit of claims. I9I6. I4 p.

Rules governing the presentation and audit of demands against state funds and appropriations. 1917. $16 \mathrm{p}$. 


\section{EFFORTS FOR ADMINISTRATIVE REFORM}

Statement of John Francis Neylan, chairman, State board of control, to Finance committee of Senate and Ways and means committee of Assembly, on condition of Treasury of state of California. I917. 8 p.

Accounting procedure for uniform system of county accounts. Department of public accounting, State board of control. [1918?] various paging, forms.

Wisconsin: State Board of Public Affairs. In the same year, I9II, that California provided for its State Board of Control, Wisconsin provided for a somewhat similar body under the name of State Board of Public Affairs. This body, however, was given quite a different composition from that of the California board. The latter, it will be remembered, is composed of three appointees of the Governor having no other official duties. The Wisconsin board was made to consist of the Governor as chairman, the secretary of state, the chairman of finance committees of the two houses of the legislature and two other members to be appointed by the Governor by and with the advice and consent of the Senate. That the activities of the University of Wisconsin, or at least of certain of the members of its faculty, in respect to governmental matters were resented by the legislature is shown by the odd provision that the appointed members should not be members of the faculty of that institution. By a statute passed in I9I3, the membership of the board was increased by adding to it the President pro tem. of the Senate, the Speaker of the Assembly, and a third appointed member, and certain other changes were introduced. Since then the act has been amended on several occasions. ${ }^{1}$

According to this act, as originally passed and as amended in I9I3, the board had the powers only of taking steps looking to the formulation of the estimates according to a uniform plan and of compiling and submitting the estimates as received by it. In I9I 5 the act was so amended, however, as not only to confer upon the board the duty of submitting its recommendations in respect to appropriations needed but of acting as a general administrative board to prescribe methods looking to the efficient conduct of public affairs. Thus, after

${ }^{1}$ For a copy of the act as amended see, The Movement for Budgetary Reform in the States. 
conferring full powers upon the board to make inquiries regarding the organization and methods of work of all state departments and institutions, the act provides that:

(I) The board shall have such supervision of every public body as is necessary to secure uniformity and accuracy of accounts. It may inquire into the methods of conducting the affairs of any public body; it may prescribe and direct the use of such forms of accounts as may be necessary to carry out the purposes of this chapter; it may prescribe and direct the use of standards and records of efficiency of employees; it shall inaugurate, supervise and conduct adequate systems of examination and inspection of accounts of every such public body, it may cause to be prepared suitable blanks, books and records for carrying out the purposes of this chapter; and shall, when necessary, furnish such blanks and records to any such public body, provided, that when the expense of such blanks, books or records has been charged against the appropriation for the board of public affairs the secretary of state shall charge the cost of supplies so furnished against the general appropriation account of the public body receiving the same and shall credit the appropriation of the board of public affairs with a like amount.

(2) The board shall devise for all public bodies uniform systems of accounts and uniform accounting procedures adequate to record in detail all transactions affecting the acquisition, custodianship and disposition of values, including cash receipts and disbursements, and every such public body shall keep its accounts and maintain its accounting procedure accurately and faithfully as prescribed and directed by the board.

Following this the board is specifically entrusted with the duty of formulating and submitting to the legislature a budget with supporting documents.

Among the reports of this board special mention might be made of the volume on The Budget, prepared for the board by S. Gale Lowrie, since it represents one of the earliest comprehensive studies of this important subject. 


\section{EFFORTS FOR ADMINISTRATIVE REFORM}

\section{PUBLICATIONS}

The budget, by S. Gale Lowrie. Madison, Wis. Democrat printing company, state printer, I9I2. 259 p.

At head of title: Wisconsin State board of public affairs.

A plan for a coöperative neighborhood; prepared and presented to the State board of public affairs, by Albert L. Williams. Madison, I9I2. I8 p.

Report on agricultural settlement and farm ownership. Pt. I-Madison (Democrat printing company, state printer). I9I2Contents.

Pt. I. State loans to farmers, by W. M. Duffus. I9I2.

Report upon coöperation and marketing. Madison, Wis., Democrat printing company, state printer, I9I2Contents.

Pt. I. Agricultural coöperation, by J. F. Sinclair. IgI2.

Pt. III. Municipal markets, by J. F. Sinclair [and] C. Hallam. I9I2.

Pt. IV. Distributive or store coöperation, by J. F. Sinclair. I9I 2.

The public money, where it comes from, where it goes. A statement of the receipts and disbursements of the state and local governments, prepared by the Wisconsin tax commission and issued by the State board of public affairs ... Madison, Wis., I9I4. 5I p. incl. tables, charts.

Conditions and needs of Wisconsin's normal schools. Report of cooperative survey, by A. N. Farmer, director ... [1915] 653 p. front., fold. maps, fold. tab., diagrs.

Survey summary re University of Wisconsin, containing the portion thus far released by the State board of public affairs as submitted December I, I9I4, by William H. Allen, director. Madison, Wis., Wisconsin efficiency bureau, I9I5. I07 p. Contents.

I. Scope and method of the survey.

II. What its university means to Wisconsin.

III. Earmarks of efficiency and progress.

IV. Opportunities for increasing efficiency.

Report upon the survey of the University of Wisconsin; findings of the State board of public affairs and its report to the Legislature ... Madison, Wis. [1915] xi, 957 p. forms, tables, chart, maps.

Appendices: W. H. Allen's report to the board, E. C. Branson's report to the board, comment by committee of University faculty upon report of investigators.

Wisconsin state budget, showing actual receipts and disbursements for I9I3-I9I4, I9I4-I9I5, and I9I5-I9I6, and estimated receipts and disbursements for 1916-1917, 1917-1918, and 1918-1919. Comp. for the use of the Legislature, I9I7, by the Wisconsin State board of public affairs, December I, I9I6. $344 \mathrm{p}$.

In pocket: "Recommendations of the Board of public affairs on the budgets of the boards, departments, and commissions, as submitted for the consideration of the I9I7 Legislature." (22 p.) 


\section{ORGANS OF ADMINISTRATIVE CONTROL}

\section{Miscellaneous}

(Complete titles unknown: Not known whether printed or typewritten)

Investigation of efficiency and cost of state printing.

Investigation of feasibility of a central board of control for all public educational institutions.

Report submitted to the Civil service commission on departmental organization and efficiency of state employees.

State receipts and expenditures, I903-I9I4.

Survey of the High schools.

Massachusetts: Supervisor of Administration. Elsewhere in this volume an account has been given of the Massachusetts Economy and Efficiency Commission, created in I9I2. By act of June I, $1916,{ }^{1}$ this commission was abolished and its powers and duties transferred together with those of the Board of Publication, a body created in 1902, to a new office created by the act known as office of Supervisor of Administration. The statute authorizes the Governor, with the advice and consent of the council, to appoint the supervisor at a salary of $\$ 5,000$ for a term of three years. The supervisor is authorized to appoint a deputy or deputies, with the consent of the Governor and council and to appoint a secretary, experts, clerks and other assistants, subject to the approval of the committee on finance of the council, which is made "a board of advisers of the supervisor."

Due to the fact that this office took over the powers and duties of prior existing authorities, it is necessary to refer to a number of acts to determine the scope of its functions. Fortunately, however, the supervisor in his first annual report has made an exceptionally clear statement of both the general functions of his office and the specific duties with which he is charged. His statement follows:

The office of Supervisor of Administration is a staff agency for exercising supervision over certain activities of State departments, and for conducting investigations and studies into the organization and business methods of the State government. The work is to be performed for, and all reports and recommendations are to be rendered to, the Gov-

${ }^{1}$ Massachusetts, Acts, I9I6, Ch. 296. 


\section{EFFORTS FOR ADMINISTRATIVE REFORM}

ernor, Council and General Court. Some of the activities are undertaken on request of the Governor, Council or Legislature, and other activities are conducted on the initiative of the Supervisor, acting under authority vested in him by statute. The authority of the office to conduct investigations and studies extends to 'every officer or board having charge of any department, institution or undertaking which receives an annual appropriation of money from the treasury of the commonwealth, including annual appropriations to be met by assessments.' Under this provision, it appears that the Supervisor may be authorized to make studies into the work of the Legislature and judiciary. In view, however, of the constitutional and statutory powers of those two branches of government, and of their functions being wholly distinct from those of the executive division of government, the work of the Supervisor's office must be in practice limited to the consideration of the various departments, boards and institutions in the executive branch of the State government, unless a specific request were made by the General Court for an examination into some matter under its control or that of the courts.

The activities prescribed for this office by statute comprise four more or less distinct classes, namely, supervision over certain departmental activities, investigations into the management of individual departments, publication of a list of State officials and employees, and the making of constructive studies. The law does not group the department's activities into separate classes, but such an arrangement is here given in order to show clearly the nature of the different duties which this office must perform.

Supervisory Duties. The Supervisor's office is vested with certain supervisory authority in connection with the following departmental activities:

I. Purchasing Methods. The statute establishing the Supervisor's office provides that he may, with the approval of the Council committee on finance, 'designate a deputy to act as investigator of purchases who shall, under the direction of the supervisor investigate the method of purchasing all stores, supplies and materials used by the commonwealth or by any officer, board, bureau, commission, institution or department maintained or employed by the commonwealth. Such deputy shall report the results of his investigation with his recommendations to the Supervisor who may, after a hearing before 


\section{ORGANS OF ADMINISTRATIVE CONTROL}

the governor and council given to the officials concerned, and with the approval of the governor and council, order changes made in the methods used in, and makes rules and regulations, not inconsistent with law, governing the purchase of stores, supplies and materials in any or all of the offices, boards, bureaus, commissions, institutions and departments of the commonwealth. Copies of orders or rules and regulations so made shall be transmitted to the officials concerned. Any appointed official who fails to comply with an order, rule or regulation duly made under authority hereof may be removed by the governor with the advice and consent of the council.'

Formerly the supervisor of accounts in the Auditor's office was authorized by law to inquire into the methods used by State departments and institutions in purchasing and handling stores, supplies and materials, and to report to the Auditor such changes as the supervisor deemed wise. These powers and duties were transferred to the Supervisor of Administration by the statute creating his office.

2. Examination of Departmental Publications. It is the duty of the Supervisor 'to examine the annual reports and all special reports and other documents issued by or on behalf of the commonwealth by any public officer, board or commission,' excepting the reports of the officers of either branch of the General Court and of elected officials. The law authorizes this office to 'define the form and extent' of the reports, 'to determine the number of pages to which any such report may extend, and to determine whether it shall include maps, plans, photogravures, woodcuts or other illustrations.' The examination of reports was formerly the duty of the Board of Publication, and was transferred to the Supervisor upon the establishment of his office and the abolition of the Board of Publication by chapter 296, General Acts of I9I6. An appeal from the Supervisor's decision regarding any proposed publication may be taken to the Council committee on finance, whose decision shall be final.

The principal classes of printing which do not come within the scope of this office's examination are the statute books, manual of the General Court, journals and all other legislative printing, ballots, and other election printing, printed forms used by departments as work sheets in the conduct of their routine business, and the annual reports of elected officials. Expenditures for these classes constitute nearly two-thirds of the State's printing bill. 


\section{EFFORTS FOR ADMINISTRATIVE REFORM}

3. Approval of Measures for Prescrvation of State Records. Proposed measures for safeguarding the records of the Commonwealth must be approved by the Supervisor, before such measures shall be put into effect by the Commissioner of Public Records.

Departmental Investigations. The statutes provide that the Supervisor's office shall make certain investigations and reports which have to do with routine departmental administration and which may be briefly described as follows:

I. Special examinations of any matter affecting the management of finances of any department or institution are made upon request of the Governor, the Council committee on finance, the Legislature or the ways and means committee of either branch. Similar examinations may be undertaken on the initiative of the Supervisor, under authority vested in him by statute. This class of work was required of the former Commission on Economy and Efficiency. The examinations here referred to have to do with the details of management in a single department, in contrast to those investigations or studies relating to broad and important subjects of administration, such as standardization of salaries, budget procedure, etc., which are described with the constructive studies prescribed for this department.

2. Reports on estimates for appropriations are made upon request of the General Court, the ways and means committee of either branch, the Governor, the Council or the Council committee on finance. This duty is a modification of that imposed upon the former Commission on Economy and Efficiency, which was required by statute to report on all appropriation estimates without being specifically requested.

Annual Publication of List of State Officials and Employees. The publication annually on or before October I 5 of a list of the officials and employees in the State service on July I (Public Document No. 90) has been transferred to the office of the Supervisor. Formerly this duty was imposed on the Governor and Council, and the list for I916 was published under their jurisdiction, as the Supervisor's department was established too late to perform the work for this year.

Constructive Studies. The study of certain administrative problems which are met with generally throughout the State service was transferred to the Supervisor's office upon the abolition of the Commission on Economy and Efficiency. The statute enumerates the following subjects for study: 


\section{ORGANS OF ADMINISTRATIVE CONTROL}

I. The laws governing the financial transactions of the commonwealth.

2. Reorganization, consolidation or coördination of departments and institutions.

3. New methods of administration.

4. Classification of employees, and fixing maximum and minimum salaries.

5. Standardization of vacations.

6. Budget method of appropriating money.

The desirability of establishing a central purchasing agency or department is enumerated among the studies transferred from the Commission on Economy and Efficiency. The provision for such a study, however, has been practically superseded by the specific authorization for an investigation of purchasing methods set forth in the act creating this office.

Further provision for study of salaries was made by the General Court of 1916, which requested the Governor and Council 'to undertake an examination of the salaries and compensations paid to officers and employees of the commonwealth and of the several counties thereof. exclusive of the department of legislation and persons in its immediate service.' By a vote of the Council a special committee of three of its members was appointed to conduct the investigation requested by the General Court, and the Council also voted 'that the Supervisor of Administration be authorized and requested to give the assistance of his department to the investigation as planned by this committee.'

Special Investigations authorized by the General Court of I9I6. The following special investigations and duties were transferred from the Commission on Economy and Efficiency to the Supervisor's department:

I. To report, with any recommendations deemed expedient, relative to the advisability of providing pensions for the needy blind (chapter I39, Resolves of I916).

2. The Supervisor, as successor to the Commission on Economy and Efficiency, is a member, ex-officio, of the special commission established by the General Court (chapter Io6, Resolves of I9I6) to investigate the subject of agricultural education as conducted at the Massachusetts Agricultural College, and the development of the agricultural resources of the Commonwealth. This investigation has consumed a material amount of the Supervisor's time, but has not otherwise increased the work of his department. 


\section{EFFORTS FOR ADMINISTRATIVE REFORM}

\section{PUBLICATIONS}

[First] annual report of the Supervisor of administration. I9I6.

Boston, Wright \& Potter Printing Co., state printers, I9I7. 22 p. (Public doc. No. I19.)

Continues the report of the Commission on economy and efficiency.

Contents.

Nature and scope of powers and duties.

Work performed.

Recommendations.

[Second] annual report of the Supervisor of administration. I9I7.

Boston, 1918. I8 p.

Contents.

Financial summary.

Reports.

Additional legislation of the year I9I7 directly affecting the department of the Supervisor of administration.

Examination of departmental publications.

Budget.

Standardization of salaries.

Purchasing control.

Consolidations.

Illinois: Department of Finance. The establishment of boards of control, as has been done by Wisconsin and California and other states, represents one form of action on the part of states in seeking to bring into existence central organs of administrative control. Another form is where general administrative powers have been conferred upon the financial department of the state government. The best example of action in this way is furnished by the state of Illinois. That state, as has been pointed out in our account of the work of its Efficiency and Economy Committee, is the one American commonwealth which has courageously reorganized her administrative system upon an integrated system. In doing so she appreciated the necessity for vesting power in some authority to secure a proper correlation of existing services and work and a unification and standardization of financial practice and procedure. To obtain this. end she made of the Department of Finance what is practically a bureau of overhead administration in respect to financial matters. ${ }^{1}$ The powers conferred upon this department illustrate so clearly the specific

${ }^{1}$ An act in relation to the civil administration of the state government. Approved March 7, I917, acts of 1917, p. 2. 


\section{ORGANS OF ADMINISTRATIVE CONTROL}

functions or duties of a bureau of general administration that it is well to. enumerate them as set forth in the act:

Section 36. The Department of Finance shall have power:

I. To prescribe and require the installation of a uniform system of bookkeeping, accounting and reporting for the several departments;

2. To prescribe forms for accounts and financial reports and statements for the several departments;

3. To supervise and examine the accounts and expenditures of the several departments;

4. To examine, at any and all times, into the accuracy and legality of the accounts, receipts and expenditures of the public moneys and the disposition and use of the public property by the several departments;

5. To keep such summary and controlling accounts as may be necessary to determine the accuracy of the detail accounts and reports from the several departments, and to prescribe the manner and method of certifying that funds are available and adequate to meet all contracts and obligations;

6. To prescribe uniform rules governing specifications for purchases of supplies, the advertisement for proposals, the opening of bids and the making of awards, to keep a catalogue of prices current and to analyze and tabulate prices paid and quantities purchased;

7. To examine, at any and all times, the accounts of every private corporation, institution, association or board receiving appropriations from the General Assembly;

8. To report to the Attorney General for such action, civil or criminal, as the Attorney General may deem necessary, all facts showing illegal expenditures of the public money or misappropriation of the public property;

9. To examine and approve, or disapprove, vouchers, bills and claims of the several departments, and such as are by law made subject to the approval of the governor and referred to it by the governor, and no voucher, bill or claim of any department shall be allowed without its approval and certificate:

IO. To prescribe the form of receipt, voucher, bill or claim to be filed by the several departments with it;

I I. In settling the accounts of the several departments, to inquire into and make an inspection of articles and materials furnished or work and labor performed, for the purpose of 
ascertaining that the prices, quality and amount of such articles or labor are fair, just and reasonable, and that all the requirements, express and implied, pertaining thereto have been complied with, and to reject and disallow any excess;

I2. To prepare and report to the governor, when requested, estimates of the income and revenues of the state;

I3. To prepare and submit to the governor biennially, not later than the first day of January preceding the convening of the General Assembly, a state budget;

I4. To publish, from time to time, for the information of the several departments and of the general public, bulletins of the work of the government;

I5. To investigate duplication of work of departments and the efficiency of the organization and administration of departments, and to formulate plans for the better coördination of departments. ${ }^{1}$

A reading of the foregoing provisions shows how important an agency this department can be for bringing about an improvement in the organization and methods of business of the government of which it is a part. It is to be hoped that its administrative reports will be of such a character as to make available to other states the results of its work.

Tennessee: State Budget Commission. On April 6, I9I7, Tennessee passed an act providing for the adoption of a budget system and the establishment of a body known as the State Budget Commission, which should have charge of the preparation of the budget for submission to the legislature. This commission is composed of the Governor, as chairman, the secretary of state, and the comptroller, treasurer and auditor of the state. In order that this body might efficiently perform its duties as a budget organ, it is also given the duty and power to make investigations into the organization and methods of work of the services and institutions of the state. The act thus provides that:

At any time the Budget Commission, or their duly accredited representatives acting under their instructions, may

${ }^{1}$ The sections of the act which follow, and which relate to the preparation of the budget, are discussed in the volume on The Movement for Budgetary Reform in the States. 


\section{ORGANS OF ADMINISTRATIVE CONTROL}

examine without notice the affairs of any department, institution, public work, commission or office of the State for the purpose of ascertaining facts and making findings and recommendations relative to increasing the efficiency of and curtailing the expense therein.

In the making of such examinations it is given power to administer oaths and to compel the attendance of witnesses and the production of records and papers.

In addition to this purely investigative power, however, the board is vested with the power of administrative control in two important respects. In the first place it is provided that "all bills introduced in either house carrying appropriations should be itemized according to the classifications and in such form as the Budget Commission shall prescribe;" and by a subsequent section it is provided that "no transfer of funds appropriated for any item in the appropriation for any state office, department, commission, board or institution, shall be made except upon the written request of the chief officer or officers of such state office, department, commission, board or institution, to the Budget Commission, which request shall be granted in writing by the Budget Commission if, in its judgment, such a transfer of funds is deemed necessary or expedient."

The possession of complete control in these two matters places the commission in so strategic a position in the administration of the state that it may readily develop into a genuine organ of central administrative control.

Other States. In the foregoing we have given an account of those state organs which have as their primary or direct function the exercise of supervision and control over the administrative services of the state with a view to increasing the efficiency and economy with which they are managed. A large number of other states have, however, made a beginning in this direction by vesting in certain state officers, such as the auditor or comptroller, the power to prescribe systems of accounting and reporting, or in certain boards the power to make such examination into the organization and methods of work of the state services as is necessary to enable them 


\section{EFFORTS FOR ADMINISTRATIVE REFORM}

properly to perform their primary duties. Thus, the acts providing for the Vermont Board of Control and the North Dakota and South Dakota Budget Boards, which act as the budget-formulating organs for those states, provide that they shall have power to visit and examine into the affairs of any state service or institution for the purpose of securing the information needed by them in preparing the budget. Acting under this authority it would be quite possible for these bodies to become effective organs of general administration.

Special mention has already been made of the Indiana State Board of Accounts, since, according to its annual report, that service has made of itself an organ for securing efficiency in the administration of public affairs generally. A very similar organ is the State Bureau of Inspection and Supervision of Public Office, created by the state of Washington in 1910, to prescribe, install and supervise the operation of a system of accounting and reporting by state officers.

Finally, there are undoubtedly a considerable number of cases where state legislatures have standing committees or have appointed special committees to consider and report upon the conduct of public affairs by the services of the state. An example of such a body is furnished by the Iowa Committee on Retrenchment and Reform which in I9I4 made a brief but interesting report to the legislature relative to the administrative branch of the government. ${ }^{1}$

${ }^{1}$ Recommendations of the Committee on Retrenchment and Reform of the 35th General Assembly and the members of the 36th General Assembly and the General Public. Des Moines, I9I4. 


\section{CHAPTER XI}

\section{ORGANS OF ADMINISTRATIVE CONTROL IN CITIES}

American city governments like those of the states have in the past few decades assumed a variety of new functions and developed administrative organizations of greatly increased complexity. Even more generally than the states they have failed to appreciate the need for creating organs of central administrative control.

A fuller development toward such agencies has undoubtedly taken place in New York than in any other American city of importance, though at the moment the situation in that city represents a retrogression from the conditions existing in this respect prior to 19I8. In the following pages the history of New York's development in this matter is set forth. No other city which has come to notice has developed organs which are so unequivocably entitled to be regarded as organs of central administrative control; but in the larger cities generally the tendency toward such development is clearly marked.

New York, N. Y.: Board of Estimate and Apportionment. The growth of central administrative control in New York is closely bound up with the development of the segregated budget. The charter of the city provides (Sec. 226) that the budget "shall be prepared in such detail as to the titles of appropriations, the terms and conditions, not inconsistent with law, under which the same may be expended, the aggregate sum and the items thereof allowed to each department, bureau, office, board, or commission, as the said ... board of estimate and apportionment shall deem advisable." Within recent years there has been an increasing exercise by the Board of Estimate and Apportionment of the power here granted, so that in most cases the budget now specifies the exact title 


\section{EFFORTS FOR ADMINISTRATIVE REFORM}

and salary of each and every employee who may be employed under the appropriation granted; and this determination may be modified during the fiscal year only by the action of the Board of Estimate and Apportionment.

To frame the personal service items of the budget in the degree of detail here indicated, and to pass upon the requests currently made by the operating departments for changes in the budget lines as thus prescribed, the Board of Estimate and Apportionment created in I9I4 a so-called Bureau of Standardis (the name of which was in I9I7 changed to Bureau of Personal Service) while for the purpose of framing the items of the budget covering the purchase of supplies or the performance of work or service under contract, and for the current investigation of the contracts proposed to be let by the departments, it created at the same time a Bureau of Contract Supervision. These two bureaus, though no longer in existence as independent organizations, possess such unique interest as marking the highest development of central agency control yet reached in municipal, and indeed in state and national, government in this country, that a somewhat detailed account of them seems warranted. ${ }^{1}$

Before proceeding to that account it should be pointed out that budget examination by an administrative agency existed for some years before the creation of these bureaus in 19I4, having been carried on by a bureau of the Department of Finance, known as the Bureau of Municipal Investigation and Statistics; and indeed that bureau continued to participate in the work of budget examination even after the creation of the two bureaus of the Board of Estimate here under discussion. Budget examination was not, however, the express function for which that bureau was created, nor was the bureau under the control and jurisdiction of the Board of Estimate, but under that of the comptroller, one of the members of the board. The creation of the two bureaus mentioned marks, therefore, the first definite recognition by the board that it could no longer itself give proper consideration to the examination of the details of the budget and to the supervision of the day-to-

${ }^{1}$ For a fuller exposition of the budgetary procedure of New York City and of the general subject matter of this chapter see, The New York City Budget, Municipal Research, No. 88, August, 1917. 


\section{ORGANS OF ADMINISTRATIVE CONTROL}

day actions of the departments taken under authority of the budget and that it must create special agencies to perform those functions.

Again, the emphasis placed upon these two bureaus should not obscure the fact that they were not technically themselves agencies of administrative control, but merely advisory agencies to the Board of Estimate, which itself was the agency of control. The bureaus were given, and could be given, no power of final determination in the matters coming before them, such power being vested by the charter in the Board of Estimate itself.

The recommendations of the bureaus' examiners as to allowances to be made in the annual budget were reviewed in the first instance by a subcommittee, composed of administrative officers representing members of the board's budget committee. The determinations of the subcommittee were in turn reviewed by the board's budget committee itself, and then by the board in full session. Owing to the enormous amount of detail involved in the examination of the budget, and the pressure of other duties, the examination given by the board's budget committee and still more by the board itself was necessarily of the most perfunctory kind. In effect, therefore, the budget was determined by a committee of administrative officers, sitting as umpire between the department on the one hand and the bureau examiner on the other.

In the case of requests for budget modifications arising during the course of the year, the recommendations of the bureaus of the board went directly to the appropriate committees of the board without the intervention of a subcommittee. In these cases the recommendation of the bureau was almost invariably accepted without change.

While the central control was thus exercised nominally by the Board of Estimate, the real organ of central control was thus, in the matter of annual budget, the subcommittee, and in other matters the bureau of the board.

Bureau of Standards (later Bureau of Personal Service). The history of the Bureau of Standards runs back to I9Io, when there was created by the Board of Estimate and Apportionment a committee to standardize the salaries of municipal 


\section{EFFORTS FOR ADMINISTRATIVE REFORM}

employees. It was not until the late fall of 1912, however, that the necessary funds for this work became available. In January and February, I9I3, a staff of examiners was organized to record and study salaries, grades and duties of employees in practically all city departments. This staff devoted itself to the compilation of definite facts relative to the character of employment of substantially every employee in the competitive and exempt classes. Records were prepared showing the essential facts theretofore unavailable relative to each position, and work commenced on drawing up definitions and specifications of employment.

At the time of the creation of this committee its work was regarded as of a terminable character. The Board of Estimate and Apportionment which came into office on January I, I9I4, however, took the view that even after a standard schedule of duties and salaries had been prepared it would be necessary to maintain a staff which should see that this schedule was currently adhered to. It created, therefore, a so-called Bureau of Standards to which was entrusted the function not merely of completing the work of drawing up standard specifications of work and compensation rates but of examining on behalf of the board all requests from departments for current changes in compensation rates of employees or for the creation of new positions, and the annual requests of departments for appropriations for personal service as contained in the budget estimates.

Upon its creation, the bureau took over all the material gathered by the Committee on Standardization and continued the studies begun by that committee. The first phase of the bureau's work, the preparation of standard work specifications and compensation rates for substantially all classes of city employees except school teachers, was brought to a tentative conclusion by the publication in I9I5 of a volume entitled Standard Specifications for Personal Service, in which the various positions in the city service were classified by "services," "groups," "positions," and "grades," the duties appertaining to each of these classifications defined, and a salary rate or scale proposed for each. A revised edition of these specifications was published in the following year. 
Partly owing to the civil service difficulties encountered in attempting to readjust the titles and compensation rates of employees already in service to the new scale, and partly owing to unwillingness of the members of the Board of Estimate and Apportionment to take, at one stroke, an action affecting so materially the personal interests of great numbers of employees, it proved impossible to secure the adoption of the proposed specifications and classification as a whole, prior to January I, I9I8. On that date a new administration, composed largely of elements which had during the previous administration strongly opposed the proposed specifications and revised classification, took office, so that the adoption of these specifications, in the preparation of which many tens of thousands of dollars were expended, is for the present at least, out of the question.

Despite their failure to receive formal adoption, the specifications received wide practical application during the years 1915-1917 in the preparation of the annual budgets and in the current adjustments of budget items, the examiners of the Bureau of Standards being under instruction to be guided by the specifications in their recommendations of salary rates. In addition, the Civil Service Commission, which possesses large powers of classification, though not of fixation of salaries, adopted in a number of cases the proposals as to title and classification made by the bureau.

In I9I7, the work of standardizing specifications for the purchase of supplies, which had also been carried on by the Bureau of Standards, was transferred to the Bureau of Contract Supervision of which account is given below; and the name of the bureau was changed to the Bureau of Personal Service.

Early in 19I8, the new city administration abolished the bureau as a separate organization, placing the staff of the bureau directly under the control of the secretary.

\section{PUBLICATIONS}

Clerical service... [New York, I9I5?] 68 p.

Custodial service. Tentative specifications submitted by the Bureau of standards to the Committee on salaries and grades of the Board of estimate and apportionment. [New York, M. B. Brown printing \& binding co., 1915 ?] 50 p. 


\section{EFFORTS FOR ADMINISTRATIVE REFORM}

Executive service and sub-professional service. Tentative specifications submitted by the Bureau of standards to the Committee on salaries and grades of the Board of estimate and apportionment, November, I9I5. [New York, M. B. Brown printing \& binding co., I9I5] $45,66 \mathrm{p}$.

Inspectional service. Tentative specifications submitted by the $\mathrm{Bu}$ reau of standards to the Committee on salaries and grades of the Board of estimate and apportionment. [New York, M. B. Brown printing \& binding co., I9I5] IO3, [I] p.

Institutional service ... [New York, I9I5?] 6I, $26 \mathrm{p}$

Investigational and educational service... [New York, I9I5?] 85, I4 p.

Report on the cost of living for an unskilled laborer's family in New York city. Submitted by the Bureau of standards to the Committee on salaries and grades of the Board of estimate and apportionment, supporting the salary recommendations for positions in the lowest grades of the street cleaning specifications and for other positions as unskilled laborers throughout the city service. [New York, M. B. Brown printing \& binding co., I9I5] $57 \mathrm{p}$.

Skilled trades service and labor service. Tentative specifications submitted by the Bureau of standards to the Committee on salaries. and grades of the Board of estimate and apportionment of the city of New York, December, I9I5. [New York, M. B. Brown printing \& binding co., I9I5] 235, [I] p.

Standard specifications for personal service. [New York, I9I6] 93I $\mathrm{p}$.

Street cleaning service ... [New York, I9I5?] 50 p.

Report on the increased cost of living for an unskilled laborer's family in New York city. Prepared by the Bureau of personal service of the Board of estimate and apportionment. 「New York, M. B. Brown printing \& binding co.] I9I 7.32 p.

Bureau of Contract Supervision. Simultaneously with the creation of the Bureau of Standards, the Board of Estimate created a so-called Bureau of Contract Supervision. To this bureau were entrusted functions cognate to those performed by the Bureau of Standards, but having reference to the purchase of supplies and materials and to the performance of work by contract. In I9I6 the functions of this bureau were thus described in an official publication. ${ }^{1}$

I. Review and report upon the specifications, estimates of cost and forms of contract for construction work done by the city, for the purchase of equipment and other contractual service where such plans, specifications and estimates of cost

${ }^{1}$ Government of the City of New York, I9I5, p. 20. 


\section{ORGANS OF ADMINISTRATIVE CONTROL}

and forms of contract require the approval of the Board of Estimate and Apportionment.

2. Report upon requested appropriations for purposes involving physical construction, alteration, repair or maintenance and the operation of mechanical plants.

3. To make tests of deliveries on contract or open market order and make such other laboratory tests as may be requested by heads of departments or required by the Board of Estimate and Apportionment.

4. To prepare plans and specifications for work of physical construction or alteration when requested by the heads of departments or required by the Board of Estimate and Apportionment.

5. To report on progress of construction contracts when requested by heads of departments or required by the Board of Estimate and Apportionment.

6. To accumulate cost data on contract work.

7. To make examinations, analyses and reports in connection with the preparation of tax and corporate stock budgets, and in connection with the transfers, modifications and revenue bond issues and current expenditures from funds by the various departments, boards, bureaus and offices of the city and county government.

8. The establishment of standard contract practices in the various departments having charge of the construction work.

As the work is used as a basis for appropriations and current financial control of appropriations, it involves an analysis of work methods and a study of the organization of forces engaged on the work of physical construction, alteration, repair or maintenance and the operation of mechanical plants, and the needs of the various departments, boards, bureaus and offices of the city and county government for supplies, materials and equipment in connection with such work.

In addition, in 1917, there was transferred to this bureau the work of preparing standard specifications for the purchase of supplies, which had formerly been conducted by a division of the Bureau of Standards. While the standardization of supply specifications would not ordinarily be regarded as a form of central administrative control, it may properly be so 


\section{EFFORTS FOR ADMINISTRATIVE REFORM}

regarded in this case. By the city charter complete freedom in the purchase of supplies was vested in the heads of the several departments. By means of conditions inserted in the budget, however, in connection with all appropriations for the purchase of supplies or materials, the Board of Estimate has made mandatory upon the several department heads the use of the standard specifications prepared under its control. 


\section{PART III}

LEGISLATIVE REFERENCE AND BILL-DRAFTING AGENCIES 



\section{LEGISLATIVE REFERENCE AND BILL-DRAFTING AGENCIES}

A characteristic of public administration, distinguishing it sharply from that of private undertakings, is that it must rest upon a foundation of law. It is of the utmost importance therefore, if efficient administration is to be had, that this legal basis shall be of a proper character, both as regards the nature of its provisions and the technical manner of their expression. Efficient legislation must thus be deemed to be one of the prime factors of efficient administration. A service that rests upon a properly drawn body of administrative law has made a big step towards securing efficiency in operation. One which does not enjoy this advantage finds its problem of securing efficiency correspondingly more difficult, if not, indeed, impossible of solution.

It is a matter of congratulation, therefore, that recent years have witnessed a very important movement in the United States in the direction of bringing into existence agencies having for their purpose the promotion of efficient legislation. These agencies may render to the legislator services of two distinct ends. On the one hand they may furnish him with information bearing on the substantive matter of the legislation which he has in mind. This is the function of legislative reference libraries, so-called. On the other hand, they may provide the legislator with expert assistance in drafting the text of the proposed legislation. It need hardly be pointed out that the best results are to be obtained when both these services are furnished to the legislator. Nevertheless, not a few of our states have made provision for one of the two without the other.

In the following chapters account is given, first of those agencies which furnish both these types of service to the leg- 
islator; second, of those which furnish only bill-drafting service; and finally, of those which furnish only information.

In the case of agencies engaged in bill drafting, the aim is not to supply information as the result of scientific investigation but simply to make available the services of persons technically trained in the drawing up of projects of law. In the case of legislative reference bureaus, the element of scientific investigation plays a part since their aim is not simply to collect and classify, and thus render readily available information needed by the legislature, but upon request, or in anticipation of a request, to go afield and collect all possible information upon pending or probable subjects of legislation-the texts of bills, and official and unofficial accounts of the manner in which laws in other jurisdictions have operated. In most cases, it has not been thought necessary to publish the results of inquiries thus undertaken, but, in other cases, valuable series of publications, which will be later mentioned, have been issued.

It may, however, be observed at this point that while in most cases the legislative reference departments limit the assistance which they give to providing pertinent data, in some cases they also venture opinions as to the argumentative weight to be attached to the information which they supply. An instance of this practice is found in the legislative reference department of the Library Commission of Wisconsin. While the value of the opinions rendered by reference services may be considerable, it is clear that there is danger in this practice, since it necessarily draws the department into the arena of politics and policy with the inevitable result of bringing it into discredit, or at least into disfavor, with those who do not happen to agree with the judgments it expresses.

Before proceeding to the account of the three types of services above mentioned, it seems desirable to reproduce the very excellent discussion of the general principles which have been outlined above, and of related matters, made in I9I3 by a committee of the American Bar Association appointed to investigate the subject. This report is reproduced in the following chapter. 


\section{CHAPTER XII}

\section{THE PROBLEM OF LEGISLATIVE REFERENCE}

AND BILL-DRAFTING SERVICE

\section{A Report of a Committee of the American Bar Association, igi 3}

Your committee was appointed (I) "To consider whether some efficient agency can not be devised to provide the several State legislatures with scientific and expert assistance in the framing of legislation" and (2) report on "the existing methods of furnishing such assistance in the preparation of legislative enactments, together with a recommendation as to the part, if any, which this association should take in the matter."

The most important existing permanent public agencies for funishing information and rendering expert assistance in the preparation of legislative enactments are the State legislative reference bureaus and drafting departments.

Assistance in the framing of legislation given by existing agencies falls under two heads, legislative reference service, or the work of collecting material throwing light on the subject matter of legislation, and drafting service.

The legislative reference service, now actually carried on in several States, demonstrates that it is entirely practicable to collect, classify, digest, and index, prior to a session of a legislature, all kinds of material bearing on practically all subjects likely to become subjects of actual legislation at the session. This material, where the bureau is well run, includes not only books and pamphlets, such as might be found in an ordinary library, but also copies of bills introduced into the

- Paragraph omitted relates to composition of the committee and its method of work. 


\section{EFFORTS FOR ADMINISTRATIVE REFORM}

various State legislatures and laws which have been enacted in this and foreign countries, and other printed materials relating to the operation of such laws or the conditions creating a need for them. Indeed, on most subjects of possible legislation, the difficulty is not to find material, but to arrange the large mass of available material so as to make its efficient use practical. That such service has great possibilities of usefulness is evident, especially where the service is directly contributory to the drafting service, a matter to be presently explained. The increasing complication of our industrial, social and governmental administrative problems renders it necessary, if the discussion of matters pertaining to legislation is to proceed in a reasonably intelligent manner, that systematic effort be expended on the collection and arrangement of material bearing on current matters of public discussion likely to become the subject of legislative enactment. A central agency to furnish such service does not take the place of special commissions or committees created to investigate particular subjects and recommend legislation. The object of the central reference service should be to assist such bodies, as well as individual members of the legislature and others desiring information pertaining to subjects of legislation.

Existing agencies also demonstrate that it is possible to provide expert drafting service for the more important measures and some assistance in the drafting of all bills introduced. The number of bills, for which expert drafting assistance can be furnished, would appear to be merely a question of the size of the force and the amount of the appropriation for its support. Your committee, therefore, believes that it is entirely practical to establish, in connection with any legislature, a permanent agency capable of giving expert drafting assistance for all bills introduced, and they urge the Association to place itself on record as favoring such an agency as the most practical means of bringing about scientific methods of legislation, that is to say, methods of drafting statutes which will secure:

I. Conformity to constitutional requirements.

2. Adequacy of the provisions of the law to its purpose.

3. Coördination with the existing law. And 


\section{THE PROBLEM OF LEGISLATIVE REFERENCE}

4. The utmost simplicity of form consistent with certainty.

The technical shortcomings of our statutes are chiefly due to the fact that they come from so many hands working without supervision and without a concerted plan. Each statute is apt to create, to some extent, an administrative machinery of its own, to have its own peculiar provisions for sanction and enforcement, and to frame new rules and principles applicable to already existing acts in pari materia. The multiplicity of separate provisions for separate statutes produces confusion, and unnecessarily encumbers our law.

A distinct drafting service will produce the one thing indispensable to scientific legislation: a professional attitude of mind, which means training for the work, devotion to it, and a reputation at stake in its proper execution, without which a high quality of workmanship is as unlikely in legislation as in any other work.

The organization of the two services, legislative reference and legislative drafting, and their relation to each other, are important factors in the usefulness of the results obtained from the establishment of the service. The agencies now existing, considered from the point of view of organization, fall into two classes; those in which the legislative reference work and the bill drafting are provided for in a single permanent bureau, as in Wisconsin, Indiana, and Pennsylvania, and those in which the legislative reference work is carried on by the State library or one of its divisions, the drafting work being done by persons appointed by and operating under the direct control of the legislature, as in New York, Connecticut, and Massachusetts. Your committee does not feel that they are as yet in a position to express an opinion on the relative merits of either form of organization. They are, however, of the opinion that the reference service should be so organized and operated as to be directly contributory to the drafting service, and that all questions of organization of the two services, their physical location and the relation of the reference work to the other ends than the drafting of bills, as, for instance, supplying to legislators and others material for the discussion of pending or possible legislation, should be decided with this 


\section{EFFORTS FOR ADMINISTRATIVE REFORM}

fundamental principle in mind. Where, as in New York, the reference service is not used by the drafting department, comparatively little use of the reference service is made by members of the legislature. Again, if the drafting service makes no use of the reference service, the drafting service is necessarily confined to minor matters of form.

It is, of course, essential that the member, administrative officer, committee, or commission, employing the drafting service shall be the final judge of the policy to be expressed in legislative form. Any one entitled to use the service shall be entitled to it without regard to the effect of the bill which he desires to have drawn. It is, however, not only proper but vital if the drafting service is to do more than correct obvious clerical and formal errors, for those in charge of the work to be able, through their access to the reference material, to indicate, if desired, to the sponsors of the legislation the statutes of other States or countries dealing with the same subject, or direct their attention to any other material collected by the reference service. Theoretically, the member of a legislature desiring assistance in the preparation of bills, if there is no cooperation between the reference and the drafting service, can go first to the reference service for material and then to the drafting service. Practically, however, in the great majority of cases, the member seeks the aid not of the reference but of the drafting service. That service should be in a position to place the member in possession of all pertinent matter in relation to the subject. Furthermore, the draftsman himself should be in a position to ask the person, commission, or committee intelligent questions as to the details of the measure desired. This he cannot do unless he himself has some familiarity of the subject matter. Where the draftsman is not in a position to refer the person or persons desiring the legislation to material bearing on the subject, and where he is not in a position to ask intelligent questions as to details, his assistance is necessarily confined to minor questions of form and, consequently, the effectiveness of the drafting service is reduced to a minimum. The valuable results obtained in Wisconsin are due to a combination of causes, not the least of which is the personality and ability of Dr. Charles 
McCarthy, the well-known head of the service. Another contributory cause, however, is the fact that that service has gone beyond mere form, without any attempt to control matters of policy, and this would have been impossible if the reference work had not been organized so as to be contributory to the drafting service.

Your conmittee also believes that another essential requisite is that both services shall be so organized as to secure permanency of tenure. To be of real value the service must be used and this cannot be unless there is confidence both in the competency and the impartiality of the personnel of the service. Under the most favorable conditions such confidence is a matter of slow growth. There is a great difference in the value of the service in different states, where either a reference or a drafting service or both have been organized. There is also even more difference in the use which is made of the services established. We are glad to report that the reappointment of directors and chief assistants, regardless of party considerations, is almost universal. It is to this fact, as well as to the inherent necessity for both branches of this service, in view of existing conditions, that the growing confidence in the work of the respective organization in the several states where the service exists may be traced.

As stated, the present force available in any state which has established a central drafting service, is not sufficient to furnish efficient expert assistance in the drafting of all bills introduced. Your committee recognizes that this condition is likely, in most states, to persist for some time. All that can be done, even by such an organization as that maintained in Wisconsin, is to give as much time as possible to the demands of each member, reserving special men for what are recognized as the big important measures of the session. While it is important that all bills introduced should be well drawn, the drawing of the bills that become law is of first importance. In nearly every state the more important bills enacted into law fall under one of the following heads: Administration bills, that is, bills dealing with matters referred to in the governor's message and probably prepared under his direction; Commission Bills, that is, bills prepared by special commissions ap- 


\section{EFFORTS FOR ADMINISTRATIVE REFORM}

pointed for the purpose; Committee Bills, that is, bills prepared by some special or joint committee of one or both houses; and Department Bills, or bills which have been prepared under the direction of one of the executive departments. In view of this fact, your committee is of the opinion that where full and adequate service cannot be given to all bills, preference should be given: First, to Administration Bills; second, to Commission Bills; third, to Committee Bills; fourth, to Department Bills; and fifth, to Members' Bills. Your committee believes that the recognition of this principle is of great importance to the efficient operation of the drafting service.

Again, it is not only important that bills such as Administration and Commission Bills be given preference, but it is also perhaps vital to the permanent usefulness of the service and even its continuance, that the administration, the executive departments, commissions and committees, shall recognize their obligation to at least avail themselves of the drafting service. The present tendency in this country is to have important legislation prepared by special committees, or by commissions, or under the direction of the administration. A drafting service, whose operations are practically confined to the preparation of Members' Bills, is, therefore, a service confined to preparing bills not likely to become law, or pertaining to matters of comparatively slight significance. Such a service can never have an important influence on actual legislation and will never receive either from the legislature or the public that attention and consequent support which is essential to efficient work. The tendency to have legislation on important subjects, prepared for submission to the legislature by persons especially designated for that purpose, is one which is on the whole producing excellent results. A commission charged with the preparation of a bill on a particular subject, is usually composed, in part at least, of experts on the subject, and it is customary for them to secure as secretary or special draftsman some one learned in the law. But the average lawyer of experience is very far from being a trained draftsman, and bills prepared by commissions, while usually a great improvement on bills introduced by members on their own initiative, are by no means free from faults of form and graver faults of confusion 
and obscurity of expression, all of which could have been easily avoided, if, in addition to special expert service, the body responsible for the bill had at their disposal the services of a trained draftsman and had availed themselves of such services.

The efficiency of the drafting service depends not only on the personnel, and on the recognition of certain fundamental principles of organization and operation, but also, your committee believes, on the existence of a harmonious body of principles to be observed, in the drafting of legislation. It is, however, obvious that some systematic plan and effort will be needed to produce a harmonious body of principles which can be used by drafting bureaus.

As we look to constructive work in economic and social science to furnish principles of legislation on its substantive side, so we have to look to legal'science to furnish such principles for the formal or technical side of legislation. Thus the history of liquor legislation in this country furnishes much valuable data in the matter of law enforcement which should be made available in the drafting of other classes of statutes; the same is true of factory and labor legislation for the problem of meeting the most obvious contrivances for evading statutory requirements.

Unfortunately there is no book written in the English language discussing, in the light of administrative and judicial experience, the legal ways and means by which a given legislative policy can best be rendered effective, or the arrangements and institutions which at present serve that end. The reason for this must be found in the large commercial demand for legal works available for the business of litigation, which has absorbed the attention of jurists to the utter neglect of scholarly or literary service to the no less important business of legislation.

If The lawyer's treatment of the law is analytical, the legislator's constructive. To the lawyer it is a fixed quantity to which he must adjust himself, to the legislator a potential force which he may fashion for his purpose. Obviously, the two points of view are entirely different. The material that the lawyer needs has been collected and digested with a degree of completeness that leaves hardly anything to be desired. 


\section{EFFORTS FOR ADMINISTRATIVE REFORM}

But while the legal material that the legislator needs, the history of statutes and of their construction by the courts may also be found, to a considerable extent at least, scattered through the law reports, there is no key to it through digests or treatises adapted for his purposes. In many cases the attorneys of private interests alone possess the knowledge that is needed for intelligent legislation and the public does not always profit by that knowledge.

Your committee, therefore, submits that the Association should lend its influence and aid toward the work that needs to be done in this field. The object to be aimed at ultimately would be the production of something like a legislative manual or code, a collection of directions or suggestions to draftsmen, and of model clauses for constantly recurring statutory provisions and problems. Carefully worked out, and having the sanction of the approval of representative bodies of lawyers and of students of legislation, such a guide could not fail of having considerable effect of drafting all over the country, and the establishment of drafting bureaus would be appropriately supplemented by giving their work from the very start a scientific and uniform direction.

As a preliminary part of the work, some systematic plan of topics should be agreed upon for further elaboration. The committee, in Appendix $\mathrm{C}$ of this report, presents a tentative draft of such a plan. It is undersood that a committee of the American Political Science Association will recommend a similar arrangement of topics, and it is very probable that directors of existing bureaus and others will aid in working out such a plan. If the Association sees fit to continue this committee, we believe that it should be directed to formulate and report to the Association a legislative manual or code as above described, if further investigation shows such preparation to be practical. The committee should also have permission to coöperate in the preparation of the manual with other public bodies interested.

Your committee believe that the establishment of permanent reference and drafting services and the general use of a harmonious body of principles relating to the science of legislative drafting will do much to prevent the enactment by 
legislatures of unconstitutional, obscure and otherwise defective legislation. At the same time, your committee realizes that legislation effective to its purpose can only be normally produced when legislative procedure tends to insure that all bills of moment shall be carefully prepared, and, being so prepared, also insures for them thorough consideration. England has apparently evolved a legislative procedure which, in the great majority of cases, produces this result. This has been accomplished through the rules of the House of Commons, which practically confine the attention of Parliament to bills introduced by the Government. Though any member has the right to introduce a bill on any subject, the rules have assigned the largest part of the time of Parliament to Government Bills. The executive or cabinet is part of the legislature and primarily responsible for the initiation of all important legislation. Thus Mr. Bryce informs us that: "Four-fifths of all the bills that are passed, nineteen-twentieths of those that are of high significance are passed at the instance of the executive government."

Our conditions are not those of England. The separation of the legislative from the executive has been too long a part of our constitutional system to make the consideration of the adoption of the English system now practical. Our efforts, therefore, should be devoted to evolving from our own conditions a legislative procedure which will normally produce what the English procedure produces, namely, the careful preparation and consideration of all legislative enactments of importance.

Several plans with this object in view have been suggested, or are in actual operation, in some one state. Your committee has given such consideration to these plans as time permitted, though in respect to two only do we feel that we can express at present even a qualified opinion.

First, it is suggested that the right of the member of the legislature to introduce bills should be curtailed. Your committee does not believe that this is practical or, if practical, desirable. To require the consent of a certain number of members to the introduction of a measure, which is the form 
which the suggestion usually takes, would probably be ineffective, as out of courtesy the permission could practically always be obtained from the requisite number. If effective, it may well be urged that the free right of introducing billseven the custom of members introducing bills at the request of a constituent, though out of sympathy with its provisions -through the consequent publication and publicity, has often distinct educational value. The effect of the introduction of a large number of bills in producing ill considered and inadequate legislation is probably exaggerated. In most cases a considerable portion of the bills introduced deal with matters of local and special concern, while the great majority even of bills of general import are not introduced with any idea of their present consideration by the legislature. If we take from the statutes passed the local and special acts and the appropriation acts, the criticism which can be usually made as to the residue is not so much its volume, but that much of it shows, entirely apart from the wisdom of the policy which it is desired to express, the haste with which the statute was prepared and the lack of consideration given to the adequacy of its provisions to effectuate its purpose.

A plan worthy, we believe, of careful consideration is that recently adopted in California. By constitutional enactment the legislature meets bi-annually on a given Monday in January next succeeding the election of members, and continues in session for a period not exceeding thirty days. Thereupon a recess must be taken for a period of not less than thirty days, and it is provided that on the reassembling of the legislature no bill shall be introduced in either house without the consent of three-quarters of its members. This constitutional provision was adopted in October, I9II. The plan, therefore, has only been in operation during the existence of the present legislature. In the Senate I7I7 bills were introduced during the first session, 60 at the second session. In the House 202 I bills were introduced at the first session, IO5 at the second. The information received by your committee would indicate that there is considerable difference of opinion among the members of the legislature as to the result of the 
operation of the plan. Where the opinion is favorable, it seems to be admitted that the experience so far is not conclusive.

Another plan designed to create an opportunity for due consideration of the measures of first importance is that recently put in force in Illinois, where the House, at the present session, established a rule favoring Administration Bills (made such by a message of the governor), which, under the rule, go at once to the Committee of the Whole, and for the consideration of which one day each week is set apart.

In general accord with this last plan, more especially, however, to the end that the legislature, on its assembling, should have before it bills of significance carefully prepared, it has been suggested that constitutional provision should be made requiring the executive to submit bills dealing with any matter recommended in his message to the legislature as a proper subject for legislation, or, at least, that this Association should specially commend the practice.

Finally, there was presented to the committee the plan embodied in a bill recently introduced into the Illinois legislature. This bill provides for the establishment of a joint legislative commission composed of the Governor, Lieutenant-Governor, Speaker of the House, chairman of the Committees on Appropriation of the Senate and the House, chairman of the Committees on Judiciary of the Senate and the House, together with five other Senators and five other members of the House. The purpose of the commission in general is to prepare in advance of legislative sessions a program of legislation with drafts of bills on subjects investigated by the commission. To this end the commission is given power to appoint special committees of its own members or others to study particular problems and draft bills.

Though your committee does not feel that it is in a position to express any opinion on the details of this bill, they do believe that it is worthy of general commendation, as the first serious attempt to evolve from our existing conditions a legislative procedure which will tend to insure the adequate preparation and consideration of important legislation. The per- 
sonnel of the commission suggested, including as it does the chief executive and legislative officers, recognizes actual conditions, which make our legislation the joint act of two independent bodies, the legislature and the executive.

Your committee is of the opinion that improvement in our state statutory law would result by reducing the number of local and special bills, but the investigation that they have been able to make of this subject leads them to believe that this result should be accomplished by custom and legislative action rather than by additional constitutional inhibition. The committee believes that the method of providing for local and special legislation should, if the committee is continued, be given further consideration.

Your committee has not considered what method, if any, can be devised to insure the proper preparation of acts which become law through the operation of what is known as the "initiative" without action by the legislature. Not only the time at our disposal, but the terms of the resolution appointing us, have confined our investigations to conditions pertaining to acts passing a representative assembly before becoming law. As, however, in several states, acts may now be placed on the statute book without the action of the legislature, your committee believes that if the committee is to be continued, they should be given power and direction to inquire what, if any, scientific assistance and what, if any, rules of procedure may be given or adopted which will normally tend to improve this class of statutory law.

Your committee believes that the Association, in providing for our appointment and especially in charging us with the duty of ascertaining whether an efficient agency cannot be devised to provide the state legislatures with scientific and expert assistance in the framing of legislation, recognized the importance of improving the character of our statutory law, and the possibility of the Association lending its aid to constructive work having this end in view. Your committee has come to the conclusion that such expert assistance can be and should be provided. They are also of the opinion that the Association can do no more useful and constructive work than to assist in 


\section{THE PROBLEM OF LEGISLATIVE REFERENCE}

the creation. of a harmonious body of principles relating to the drafting of statutes, and, finally, that the Association may, with reasonable hope of profitable results, investigate methods of providing for local and special legislation, and also investigate the rules of legislative procedure and rules pertaining to the operation of the initiative, with a view of ascertaining whether there are any principles or practices the adoption of which will tend to render our statutory law more in accordance with constitutional requirements, more consistent with itself, and, finally, more simple and certain in its form. To carry out these conclusions your committee has prepared and submits herewith two resolutions, one commending the establishment of permanent central agencies in the several states and at Washington, to furnish expert legislative drafting and reference service, and the other, continuing the committee and imposing upon it the duty of preparing a report on the other matters herein suggested.

Your committee recommends the adoption of the following resolutions :

Resolved, That in the opinion of the Association, an official legislative drafting and reference service, when properly organized and directed, forms an efficient agency tending to prevent the enactment of unconstitutional, obscure and otherwise defective statutes and to secure the utmost brevity and simplicity consistent with accuracy in the language of statutes, and we hereby recommend the establishment and generous support of such service at Washington and in those states not now having such service.

Resolved, That the Committee on Legislative Drafting be continued, with instructions to prepare for submission to the Association, if further investigation shows such preparation to be practical, a legislative manual or code containing a collection of directions or suggestions for drafting laws, and model clauses for constantly recurring statutory provisions and problems, and that the committee be further directed to report what, if any, changes in existing legislative procedure, or procedure in connection with the operation of the initiative, will tend to the improvement of our statutory law, and that 


\section{EFFORTS FOR ADMINISTRATIVE REFORM}

for these purposes the committee be authorized to coöperate with other organizations or individuals.

Respectfully submitted,

Wm. Draper Lewis, Chairman,

ERNST FREUND,

SAMUEL T. UNTERMEYER,

LOUIS D. BRANDEIS,

Thomas I. Parkinson,

Henry C. Hall.

I concur in recommending the adoption of the resolutions submitted by the report.

F. W. Lehmann. 


\section{CHAPTER XIII}

AGENCIES FURNISHING LEGISLATIVE REFERENCE AND BILL-DRAFTING SERVICE

The present chapter relates to agencies which furnish both reference and bill-drafting sęrvice.

Alabama: Department of Archives and History. While in Alabama an agency has existed since February 27, I90I, for the centralizing of official state records and the organizing of the historical resources of the state, namely, the Department of Archives and History, it was not until March 5, $1907,{ }^{1}$ that that department was given the additional function of a legislative reference bureau. This was done by the enactment of the following provision of law:

In addition to the duties now required by law, the department of archives and history shall do and perform the following. $* * *$ It shall bring together and arrange for ready consultation a reference collection of materials for the use of the members of the legislature, state officers, and others on all subjects which may, from time to time, be deemed of public interest and importance to the people of the state.

Previous to the enactment of this law and since the creation of the Department of Archives and History, February 27, 1901, the department had been active in meeting the reference and other needs of state legislators, officials and the general public.

The legislature has not made any provision bearing upon the organization of this service nor has it made any specific appropriation therefor since the original act, this service being

${ }^{1}$ Alabama, Acts, 1907, No. 255, p. 318. 


\section{EFFORTS FOR ADMINISTRATIVE REFORM}

paid for out of the general appropriations for the department.

Although no provision is made for bill drafting, both legislative reference and bill-drafting services were rendered by the department at a number of regular and special sessions of the legislature.

\section{PUBLICATIONS}

Alabama official and statistical register. I903 Montgomery, 1903Bulletin No. I-5. Montgomery, I904-I9II.

Contents.

No. I. The establishment, organization, activities and aspirations of the Department of archives and history of the state of Alabama. I904. $48 \mathrm{p}$.

No. 2. McMorries, E. Y. History of the First regiment, Alabama volunteer infantry, C. S. A. I904. I42 p.

No. 3. Check list of newspaper and periodical files in the Department of archives and history. I904.

No. 4. Laws governing the Department of archives and history. I907. $20 \mathrm{p}$.

No. 5. Revolutionary soldiers in Alabama. I9II. I3I p.

Legislative bulletin, No. I Montgomery, I9I4-

Contents.

No. I. Preliminary index to the legislative reference collection of the Department ... Comp. by Thomas M. Owen. I9I4. 4I p.

\section{Arizona: State Law and Legislative Reference Library.} The legislative reference work in Arizona was begun in I9I 5, as the result of an act approved March 24 , I9I $5,{ }^{1}$ concerning the organization of the state library. This act makes provision for the establishment of a Law and Legislative Reference Library and the appointment of a legislative reference librarian, prescribing the usual duties for the latter. In addition, the legislative reference librarian is required, upon request, to "aid and assist the members of the legislature, the governor, and the heads of departments by advising as to bills and resolutions and drafting the same into proper form." The librarian is prohibited from opposing or urging legislation. Since its establishment the Legislative Reference Library has drafted about fifty per cent of the bills, memorials and resolutions presented in the legislature.

${ }^{1}$ Arizona, Acts, 1915. Ch. 62, p. I32. 


\section{LEGISLATIVE REFERENCE AND BILL-DRAFTING}

\section{PUBLICATIONS}

Report of the Arizona state law and legislative reference librarian. I915-1916-

Check list of annual reports. I9I6-19I7. Phoenix, I9I7-

Prepared by Con P. Cronin, state law and legislative reference librarian, I916-1917-

Constitution of the state of Arizona [with amendments]. Comp. by Con. P. Cronin ... and S. P. Osborn]. 1917. 63 p.

California: Legislative Counsel Bureau. The Legislative Counsel Bureau of California was originally created by an act approved May 26, 191 $3,^{1}$ which act was amended by the act of May 31, 1917.2 As amended, the law provides for a Legislative Counsel Bureau, "which shall be in charge of a chief, to be known as the legislative counsel of California. The duty of the legislative counsel as prescribed by law is: "To prepare and assist in the preparation, amendment and consideration of legislative bills when requested or upon suggestion as herein provided. Upon request he shall advise any state officer, commissioner or bureau as to the preparation of bills to be submitted to the legislature; and when requested so to do, he shall advise as to their work with any legislative committee appointed to carry on investigations between sessions of the legislature. He shall advise the legislature from time to time as to needed revision of the statutes."

Whenever there is a probability that an initiative measure will be submitted to the voters of the state and when requested in writing by twenty-five or more electors proposing it, it is his duty to coöperate with the proponents in its preparation.

The legislative counsel is also required to prepare or assist in the preparation or amendment of legislative bills at the suggestion of the Governor or of any judge of the Supreme Court or of the District Courts of Appeal or of the Superior Court of the State, or of any committee of the Senate or Assembly of the legislature of the state. During legislative sessions the bureau is required to "give such consideration to and service concerning any bill before the legislature, as circumstances will permit" on the request of the Governor or either

${ }^{2}$ California, Acts, 1913, Ch. 322, p. 626.

'California, Acts, 1917, Ch. 727, p. 1398. 


\section{EFFORTS FOR ADMINISTRATIVE REFORM}

house of the legislature or any committee having such bills before it for consideration. After adjournment the bureau is required to assist the Governor, on his request, in disposing of any bills in his hands for rejection or approval or other action.

The act provides that neither the legislative counsel nor any employee of the bureau shall oppose or urge legislation; but the bureau, when requested, must aid and assist any member of the legislature, so far as it may be in its power, in the preparation of bills, resolutions and measures, drafting the same into proper form and furnishing the fullest information upon all matters in the scope of the bureau.

The legislative counsel is required to be in attendance upon all sessions of the legislature. He is appointed by the Governor and he appoints all the employees of the bureau.

The state also maintains, as a part of the state library, a legislative reference service. This service is organized entirely independently of the legislative counsel's office and will be treated in the chapter dealing with reference services. ${ }^{1}$

\section{PUBLICATIONS}

General election laws, supplement of igr6. Comp. by the Legislative counsel bureau. [Sacramento] California state printing office, 19I6. $62 \mathrm{p}$.

Laws of California relative to production and standard of dairy products. State dairy bureau ... Prepared by Legislative counsel bureau. I9I7. $5^{\mathrm{I}} \mathrm{p}$.

Provisions of the constitution and statutes of California governing the submission of measures to the whole people by the initiative and referendum. Comp. by the Legislative counsel bureau. [Sacramento] California state printing office. 1916. I2 p.

Constitution of the state of California and summary of amendments ... Prepared by the Legislative counsel bureau. 1917. 376 p.

Illinois: Legislative Reference Bureau. The Illinois Legislative Reference Bureau is governed by a special commission consisting of the Governor, and the chairmen of the committees on appropriation of the Senate and of the House of Representatives, provided for by an act approved June 26 , I9I $3{ }^{2}$ This commission, or bureau, appoints a secretary who is re-

${ }^{1}$ See p. 357.

${ }^{2}$ Illinois, Acts, 1913, p. 391 . 


\section{LEGISLATIVE REFERENCE AND BILL-DRAFTING}

quired to devote his entire time to the duties of his office. Provision is also made, in the act creating the bureau, for the appointment by the bureau of such other agents and employees as may be necessary.

The bureau is required to collect and make available the usual legislative reference materials; to prepare a budget of state appropriations; and "to afford to any member of the General Assembly upon his request, such legal assistance and information as may be practicable in the preparation of bills, memorials, resolutions, orders and amendments, alterations, changes thereto, and revisions and substitutes thereof, proposed to be introduced into the General Assembly by said member." This bureau has made the first attempts in the state along the lines of scientific budget making. It issues a weekly Legislative Digest.

\section{PUBLICATIONS}

Digest of legislation enacted and proposed, 48th General assembly. [Springfield, Ill., The E. F. Hartmann co., I9I3] II 2 p.

Continued by Legislative digest [for succeeding sessions of the General Assembly].

Detailed budget of the appropriations requested for the biennium I9I5-1916 filed with the l.egislative reference bureau, state of Illinois. Springfield, Ill., Jeffersons printing company [1914]. vii, 236 numb. I .

- I917-18. 1917.

Illinois party platforms, I9I4, with select bibliographies of available material on file in the Legislative reference bureau, relating to the subjects enumerated therein. [Springfield, Ill., Schnepp \& Barnes, state printers, I9I4] $43 \mathrm{p}$.

Workmen's compensation act and rules of procedure. Issued by the Industrial board of the state of Illinois... Prepared by the Legislative reference bureau. [Springfield, Ill., Schnepp \& Barnes, state printers, I9I4] $5 \mathrm{I} \mathrm{p}$.

Budget classification and rules of procedure for the officers of the several state departments for filing estimates of the appropriation which their departments may require for the fiscal period 1917-I8. [Springfield, Schnepp \& Barnes, state printers, I9I6] $23 \mathrm{p}$. incl. forms.

Lawmaking, an outline of the successive steps in the preparation and enactment of laws with notes and citations, by Joseph James Thompson. [Springfield, Schnepp \& Barnes, state printers, I9I6] $36 \mathrm{p}$.

The Legislative reference bureau, its work and functions. Legislative reference bureau, Springfield, Illinois ... [Springfield, Schnepp \& Barnes, state printers, 1916] 8 p. 


\section{EFFORTS FOR ADMINISTRATIVE REFORM}

"Compilations of the Illinois legislative reference bureau," p. 5-7. Cost of state government. Comp. by Finley F. Bell, secretary. I9I6. 46 numb. I. incl. tables.

\section{ARTICLES}

Bell, Finley F. A legislative aid: the work and functions of the Legislative reference bureau of Illinois. Case and comment, Jan., I917, v. 23: 625-29.

Indiana: Legislative and Statistical Bureau. A legislative reference department was created in the state library of Indiana as the result of an act approved on March 9, 1907. ${ }^{1}$ In I9I 3 this department was made a separate bureau by an act approved March 14, I91 $3,{ }^{2}$ the bureau being under the direction of a board consisting of the Governor, the state librarian, the presidents of the two state universities and one additional member appointed by the Governor. This act also enlarged the functions of this service to include both legislative reference and bill-drafting work. In I9I7, however, a provision was inserted in the annual appropriation act abolishing this bureau. At the same time, by another act, this department was authorized to prepare the Year Book. The Governor has continued the bureau, paying for it out of an emergency fund.

\section{PUBLICATIONS}

Bulletin [of the Legislative reference department of the State library] No. I-6. Indianapolis, I908-I9I2.

Contents.

No. I. Local option by election. I908. 2 p.

No. 2. Index to governors' messages, 1816-1851. 1908. I3 p.

No. 3. Guarantee of bank deposits, 1908. I2 p.

No. 4. Hints on bill drafting by J. A. Lapp. I910. 9 p.

No. 5. Digest of the laws of Indiana of special application to women and children. 1912. $27 \mathrm{p}$.

No. 6. Inheritance taxation, 1912. $9 \mathrm{p}$.

Bulletin [of the Bureau of legislative information.] No. I-Indianapolis, I9I3-date.

Contents.

No. I. Constitution of the United States and of Indiana, I9r3.

No. 2. Drainage and reclamation of swamp and overflowed lands, by Charles Kettleborough, I914. $68 \mathrm{p}$.

${ }^{2}$ Indiana, Acts, 1907, Ch. I47, p. 236.

"Indiana, Acts, I9I3, Ch. 255, p. 694. 
No. 3. Legislative bill drafting, 19I4. $36 \mathrm{p}$.

No. 4. Flood protection in Indiana, by W. K. Hatt, I9I4. $5^{I}$ p.

No. 5. Forms of city government, by Frank G. Bates, 1916.

No. 6. The budget, by W. T. Donaldson, 1916. $30 \mathrm{p}$.

No. 7. Control and supervision of state institutions, 1916. $40 \mathrm{p}$.

No. 8. City planning, by Frank G. Bates, I9I6. 3I p.

No. 9. The trend of legislation for public health, by Arthur Connors, 1916. $38 \mathrm{p}$.

No. Io. Control of corporate finance, by Louie J. Oberreich, 1917. $66 \mathrm{p}$.

Kansas: State Library: Legislative Reference Department. The Legislative Reference Department of the State Library maintains both a legislative reference and a bill-drafting service. It has classified and arranged the economic and legislative matter in the state library, for the use of members of the legislature, state officers and other citizens interested in state legislation. It offers trained legal assistance concerning new proposed legislation, and, when desired, places it in the proper technical bill form for introduction.

\section{PUBLICATIONS}

Bulletin No. I- Jan., I9I4- Topeka, I9I4-date.

Contents.

No. I. Legislative systems. Part I. The unicameral system. Part 2. The bicameral system. Part 3. Bibliography ... Topeka, I9I4. I44 p.

Maryland: Department of Legislative Reference. The Department of Legislative Reference is both a state service for Maryland and a municipal service for the city of Baltimore. By an act approved April 9, $1906,{ }^{1}$ it was originally created as a municipal department of the city administration of Baltimore. From the beginning, however, it has rendered services to the state legislators, and on April I8, I916 ${ }^{2}$ an act was approved imposing on its executive officer the additional duty of investigating and reporting upon the laws of Maryland and other states "any subject upon which he may be requested so to report by the Governor of Maryland, any committee or member of the General Assembly, or the head of any State

${ }^{1}$ Maryland, Acts, 1906, Ch. 565.

${ }^{2}$ Maryland, Acts, I916, Ch. 474, p. 953. 
department ;" of accumulating "all data obtainable in relation to the practical operation and effect of such laws ;" of investigating and collecting "all available information relating to any matter which is the subject of proposed legislation by the General Assembly;" and of preparing or aiding in the preparation of "any bill or resolution when requested so to do by any member of the General Assembly." The bureau maintains a branch office at Annapolis, the state capital, during the sessions of the legislature, the permanent main office being in Baltimore.

\section{PUBLICATIONS}

Annual report. Ist-Ioth, I907-I9I6.

Round table, February 26, I907. 43 p.

Remarks of Theodore Marburg, Horace E. Flack, Ira Remsen,

Westel W. Willoughby and Jacob H. Hollander, on the new Department of legislative reference.

Legislative expenditures. Legislative apportionment. Baltimore, Md. I909. 8 p. incl. tables.

Synopsis of laws enacted by the state of Maryland, legislative session, I9i6. Comp. by Horace E. Flack, Department of legislative reference, Baltimore, Md. I9I6. $56 \mathrm{p}$.

Synopsis of laws enacted by the state of Maryland, legislative session, I9I8. Comp. by Horace E. Flack, Department of legislative reference, Baltimore, Md. I9I8. $56 \mathrm{p}$.

The Maryland budget amendment. [Feb. 5, I9I7] Baltimore [19I7] $56 \mathrm{p}$.

\section{ARTICLES}

Flack, Horace E. The Department of legislative reference in Baltimore, Md. Municipal engineering, Sept., I908, v. 35: I56-62.

Michigan: State Library: Legislative Reference Department. The original act of June $28,1907,{ }^{1}$ creating the Legislative Reference Department of the Michigan State Library, made no provision for a bill-drafting service. Such a provision, however, was inserted in the act of April 25, $1917^{2}$ which amends the earlier act. As amended, the law provides that there is created in connection with the state library "a department known as the legislative reference and information department for the use and information especially of members of the Senate and House of Representa-

${ }^{1}$ Michigan, Acts, 1907. No. 306, p. 405.

Michigan, Acts, 1917. No. 120, p. 196. 
tives, the several state departments and such other persons as may desire to consult the same." It further provides that the state librarian shall appoint an assistant who shall "make available for ready reference and use, suitable indexes to all such information as is contained in the various public documents of this state and other states, including Senate and House documents and legislative journals, and shall keep a complete file of all bills printed by order of either house of the Legislature. He shall procure and compile in suitable and convenient form for ready reference and access, information as to proposed and pending legislation in other states, and shall also investigate the operation and effect of new legislation in other states and countries.... He shall also give such advice and assistance to the members of the Legislature as they may require in the preparation of bills and resolutions, and shall draft bills upon such subjects as they may require."

PUBLICATIONS

Bulletin No. I- Sept., 1907-date(?)

Contents.

No. I. Constitution of the state of Michigan, I850. Sept., 1907. $78 \mathrm{p}$.

No. 2. First state constitution, 1835. Proposed constitution of 1867. Proposed constitution of 1873. Sept., 1907. $69 \mathrm{p}$.

No. 3. Local, special and private legislation, municipal charters, gubernatorial veto, initiative and referendum as provided for and regulated by the constitutions of the several states. Sept., 1907. 24 p.

No. 4. Legislative reference list. Employers' liability and workmen's compensation. Feb., I9I I. I7 p.

No. 5. Laws of the various states relating to a minimum wage for women and minors. Nov., I9I3. $37 \mathrm{p}$.

Documents compiled for the Committee on printing of the Constitutional convention of $1907.22 \mathrm{v}$.

Pamphlets with caption titles containing constitutional provisions of other states, on various topics, compared with those of Michigan.

Contents.

[No. I] Amendment and revisions. $30 \mathrm{p}$.

[No. 2] Boundaries, seat of government and departments. $22 \mathrm{p}$.

[No. 3] Bribery and corruption. I6 p.

[No. 4] Education and public schools. $80 \mathrm{p}$.

[No. 5] Elections. $70 \mathrm{p}$.

[No. 6] Eminent domain. I3 p. 


\section{EFFORTS FOR ADMINISTRATIVE REFORM}

[No. 7] Executive department. I03 p.

[No. 8] Exemptions [from taxation]. I3 p.

[No. 9] Finance and taxation. 8I p.

[No. Io] Impeachment and removal from office. $3 \mathrm{I}$ p.

[No. II] Judicial department. 252 p.

[No. I2] Legislative department. $284 \mathrm{p}$.

[No. I3] Miscellaneous provisions and addenda. $60 \mathrm{p}$.

[No. 14] Labor interests. Io p.

[No. I5] Liquor traffic. 5 p.

[No. I6] Military affairs. $28 \mathrm{p}$.

[No. I7] Municipal corporations. I is p.

[No. 18] Preambles and bills of rights. $37 \mathrm{p}$.

[No. I9] Private corporations. II4 p.

[No. 20] Public lands and forest protection. I6 p.

[No. 2I] Rights of women. 4 p.

[No. 22] State officers; salaries; state boards and institutions. IOI $\mathrm{p}$.

Laws of the various states relating to vagrancy (with bibliography), June, 1910. $29 \mathrm{p}$.

Mortgage taxation and commission government; reprinted articles by M. A. Schaffner for the Grand Rapids (Mich.) Evening press. I908. $18 \mathrm{p}$.

The history of railroad taxation in Michigan ... by Wilbur $O$. Hedrick ... I9I2. 70 p.

Laws of the various states relating to presidential primaries. February, I9I2. $25 \mathrm{p}$.

Digest of the laws of the various states relating to motor vehicles. I9I4. 8 p.

Local legislation. Opinion of Attorney-general Grant Fellows upon what constitutes a local or special act under the Michigan constitution ... Jan. 25, 1915. 2 p.

Laws of Michigan relating to women. Comp. by Charles W. Bradrick. I916. I05 p.

Laws of the various states relating to vagrancy. Prepared by Olive C. Lathrop. Rev. ed. Lansing, Mich., State printer, 1916. 61 p. "Supplementary list of selected references on vagrancy and juvenile delinquency," p. 59-6I.

Legislative circular, No. I-2 [Lansing, I9- to 1915].

Missouri: Library Commission: Legislative Reference Department. No specific provision of law has ever been made in Missouri for the creation of a legislative reference or a billdrafting service. An act approved April 7, I909, ${ }^{1}$ provided for the establishment of a library of the General Assembly to be located at the Capitol under the control of the House or Senate during sessions of the General Assembly and under the charge of the secretary of the Missouri Library Commission at other times. No special appropriation has been made

${ }^{1}$ Missouri, Acts, 1909, p. 653. 
for this service. The library is for the exclusive use of the members of the General Assembly. Bill drafting was done to a limited extent in the legislative session of I9I7.

\section{PUBLICATIONS}

Classified index of bills prepared for 47th General Assembly, Missouri. March I7, I9I3. $34 \mathrm{p}$.

Digest of the laws of other states on prison labor, bearing on House bill 543, 49th General assembly of Missouri, I9I7. Jan., I9I7. I7 p.

Montana: State Library: Historical and Miscellaneous Department: Legislative Reference Bureau. In Montana, the Legislative Reference Burean is a section of the Historical and Miscellaneous Department of the State Library. It was organized in 1909 in accordance with an act approved March 4, I909. ${ }^{1}$ The object of the bureau as specified in the act is "to gather and make available, such information as shall aid the members of the Legislature in the discharge of their duties, and to render assistance in the drafting of bills." The act makes the usual provision for the collection of the legislative reference material.

Nebraska: Legislative Reference Bureau. The first mention of legislative reference work in Nebraska is made in an appropriation act approved April 10, $1907,{ }^{2}$ which had the following item in the appropriation for the State Historical Society: "For labor and supplies in legislative reference department." In 1909 this appropriation was repeated, but no other mention was made, in either year, of a legislative reference service. An act specifically creating a Legislative Reference Bureau was approved April 7, I9II, ${ }^{3}$ which provided that the bureau shall "gather, arrange, catalogue, compile, edit, index, and publish information upon subjects of legislation and administration;" that it shall "maintain a compact library of books, pamphlets, maps, clippings, and other material useful for its purposes;" that it shall "prepare check lists and catalogues of Nebraska legislative bills, and public docu-

${ }^{1}$ Montana, Acts, 1909, Ch. 65, p. 79.

${ }^{2}$ Nebraska, Acts, I907, Ch. I98, p. 552 .

${ }^{2}$ Nebraska, Acts, I9I I, Ch. 72, p. 3 Io. 
ments ;" that it shall "carry on research in other subjects of special public interest and publish the same in convenient form;" and that it shall "maintain a special service upon municipal subjects for use of city and village officials." The bureau is affiliated with the Department of Political Science and Sociology and with the College of Law of the University of Nebraska. The act provides that the director and his assistant, who are appointed by the board of regents of the State University, "shall neither oppose nor urge legislation, but may, upon request, aid and assist members of the legislature and the executive departments as to bills, resolutions and measures, drafting the same into proper form and furnishing to them the fullest information upon matters in the scope of the bureau."

\section{PUBLICATIONS}

Bulletin No. I-Lincoln, I912-

Contents.

No. I. Nebraska legislative reference bureau. I9I2 (folder).

No. 2. Preliminary report, Nebraska Employer's liability and workmen's compensation commission. I9I2. $48 \mathrm{p}$.

No. 3. Legislative procedure in the forty-eight states, by A. E. Sheldon and Myrtle Keegan. I9I4.

No. 4. Reform of legislative procedure and budget in $\mathrm{Ne}-$ braska. A report by Joint committee of Senate and House. I9I4. 47 p.

No. 5. Nebraska municipalities, by A. E. Sheldon and W. E. Hannan, I9I4. 74 p.

No. 6. Bank deposit guaranty in Nebraska, by Z. C. Dickinson [19I4?] $38 \mathrm{p}$.

No. 7. The direct primary in Nebraska, by N. H. Debel. I9I4. II $2 \mathrm{p}$.

No. 8. Local and Nebraska history in Nebraska public schools, by C. N. Anderson. 19I5. I5 p.

No. 9. State supported library activities in the United States, by Edna B. Bullock. I9I5. 7I p.

No. Io. The Torrens land transfer act of Nebraska, by Thorne A. Browne. I9I6. $60 \mathrm{p}$.

No. II. Legislative procedure, by M. K. Mason. Revision of Bulletin No. 3 .

No. I2. The exercise of the veto power in Nebraska, by K. E. Carlson. I9I7. 104 p.

Manual of Nebraska legislative procedure. Senate rules. House rules. Joint rules. Legislative history. Comp. by C. A. Sorensen and Myrtle Keegan. Addison E. Sheldon, editor. [Lincoln?] Nebraska Legislative reference bureau, I9I7. I24 p.

"Act establishing the Nebraska legislative reference bureau," p. II 2-4. 


\section{LEGISLATIVE REFERENCE AND BILL-DRAFTING}

Subject index of Senate and House bills and list of bills introduced by each member. Also members of Senate and House, their addresses and telephones, Senate and House committees, schedules of committee meetings. Comp. by Edna D. Bullock. Prepared and pub. by the Nebraska Legislative reference bureau, with the coöperation of the secretary of the Senate and chief clerk of the House. [Lincoln? I9I5] I26 p.

At head of title: Nebraska Legislature. Thirty-fourth session, I9I5. 4th ed.

Subject index of Senate and House bills with other legislative information. Final ed., April I, I9I7. Comp. by Edna D. Bullock. Pub. by the Nebraska Legislative reference bureau. Lincoln, Neb. [I9I7]. I 20 p.

At head of title: Nebraska Legislature. Thirty-fifth session, I9I7.

\section{New Hampshire: State Library: Legislative Reference} Bureau. The Legislative Reference Bureau in the State Library of New Hampshire was created by an act approved May 2I, I9I $3,{ }^{1}$ which provided for the establishment of a legislative reference bureau under the direction of the state librarian, whose duties in addition to the usual legislative reference requirements are to prepare abstracts of laws in other states and countries, to supply such other information as may be of service to the members of the legislature, or the executive departments in the performance of their duties, and to furnish to members of the legislature such assistance as may be demanded in the preparation and formulation of legislative bills. An amendment relating to state and other public libraries, enacted March $7,1917,,^{2}$ provides that "the trustees shall establish within the state library such catalogues and collections as in their judgment will make it most serviceable in matters of legislation."

\section{North Carolina: Historical Commission: Legislative Ref-} erence Department. The Legislative Reference Service is a department of the North Carolina Historical Commission created by an act approved March 9, I9 I $5 .^{3}$ This act authorizes and requires the commission "to appoint a properly qualified person to be known as a Legislative Reference Librarian,

${ }^{1}$ New Hampshire, Acts, I9I3, Ch. 206, p. 76r.

${ }^{2}$ New Hampshire, Acts, I917, Ch. 59, Sec. 18, p. 5 I I.

North Carolina, Acts, 1915, Ch. 202, p. 277. 
whose duty it shall be to collect, tabulate, annotate, and digest information for the use of the members and committees of the General Assembly, and other officials of the state, and of the various counties and cities included therein, upon all questions of state, county and municipal legislation." Other duties incident to a legislative reference service are also prescribed. In addition, the legislative reference librarian is required to keep the Revisal of 1905 revised to date.

While there is no specific provision in the laws requiring the Historical Commission or the legislative reference librarian to perform bill-drafting service, the Legislative Reference Department, at the only session of the legislature that has taken place since the department's creation, drew up about 500 bills for members of the General Assembly, besides furnishing data and information relating to as many more.

\section{PUBLICATIONS}

Bulletin No. I- Raleigh, 1915-

Bulletin No. I. Amendments to revisal of 1905 enacted by the General assembly of North Carolina. I907-1915. Comp. by W. S. Wilson, legislative reference librarian. (Publications of the North Carolina Historical commission. Legislative reference dept.)

First biennial report of the legislative reference librarian I9I5-I9r6. Reprinted from the sixth biennial report of the North Carolina Historical commission, I915-1916.

North Dakota: Public Library Commission: Legislative Reference Bureau. Both legislative reference and bill-drafting services are rendered by the Legislative Reference Bureau of North Dakota. This bureau is one of the departments of the Public Library Commission. It was created in accordance with an act approved March 2, 1907, ${ }^{1}$ which was amended by an act approved March 3 , 1909, ${ }^{2}$ to read as follows :

The State Library Commission shall have power and it shall be its duty to establish a legislative reference bureau for the information and assistance of the members of the legislative assembly in the work of legislation. The legislation of

${ }^{1}$ North Dakota, Acts, 1907, Ch. 243, p. 382.

${ }^{2}$ North Dakota, Acts, I909, Ch. 156, p. I9I. 


\section{LEGISLATIVE REFERENCE AND BILL-DRAFTING}

other states and information upon legal and economic questions shall be classified and catalogued in such a way as to render the same easy of access to members, thereby enabling them better to prepare their work. It shall be the duty of the legislative librarian to assist in every way possible the members of the legislative assembly in obtaining information and in the preparation of bills.

The legislative reference librarian collects information on subjects that are likely to come up for consideration when the legislature convenes. This information consists of pamphlets prepared by students of and specialists in each subject; of reports of commissions, of investigating committees, bureaus and other bodies that have conducted inquiries in specialized fields; of reports of departments of state and municipal governments that have had charge of the enforcement and administration of laws dealing with specified subjects; and of discussions from current newspapers. This material is classified and condensed for use by the legislator.

Much of the time of the legislative reference librarian is also given to bill drafting.

PUBLICATIONS

Bulletin No. I.- Bismarck, N. D., I910-

Contents.

No. I. Permanent state tax commissions, a comparative digest of state legislation; comp. by S. Johnson. I910. $96 \mathrm{p}$.

No. 2. Good roads: an outline of state road systems; comp. by S. Johnson. I9I0. $96 \mathrm{p}$.

No. 3. Budgetary laws; comp. by I. A. Acker. I912. 20 p.

No. 4. Widows' pension laws; comp. by I. A. Acker. 19 I4. $29 \mathrm{p}$.

\section{Ohio: State Board of Library Commissioners: Legislative} Reference Department. The Legislative Reference Department of Ohio was organized in I9Io as a part of the state library, in accordance with an act approved May I3, I9Io. ${ }^{1}$ The act of January $3 \mathrm{I},{ }^{1}{ }^{1} 3^{2}{ }^{2}$ amending the original act, made it a separate department with a director in charge, but under the direction and supervision of the State Board of $\mathrm{Li}$ -

${ }^{1}$ Ohio, Acts, rgro. No. 384 , p. 22 r.

${ }^{2}$ Ohio, Acts, I9r3. No. I73, p. 8. 


\section{EFFORTS FOR ADMINISTRATIVE REFORM}

brary Commissioners. The director is appointed by this board and is required to be an expert in political science, economics and public law. His duty is "to collect and compare the laws of this and other states pertaining to any subject upon which he may be requested to report by the governor or any committee or member of the general assembly; to collect all available information relating to any matter which shall be the subject of proposed legislation of the general assembly; to prepare or advise in the preparation of any bill or resolution when requested to do so by the governor or by any member of the general assembly; to preserve and collate all information obtained ... ; to collect such books, pamphlets, periodicals, documents and other literature as may be of use to the general assembly or other state officials." $\mathrm{He}$ is also required to keep a file, with index, of documents and reports of all of the states, bills and resolutions, etc. $\mathrm{He}$ is authorized to employ the necessary clerks and draftsmen.

\section{PUBLICATIONS}

Ohio canals, by C. B. Galbreath. I9II.

Initiative and referendum by C. B. Galbreath. I9I I. 79 p.

Nomination and election of United States senators, by C. B. Galbreath. I9II. I5 p.

Ohio constitutional conventions, by C. B. Galbreath. I9I I.

Public service commission laws; a comparison of the laws of $\mathrm{New}$ York, Wisconsin, Massachusetts, New Jersey and Maryland, by John A. Lapp. I9I I. 18 p.

Record of bills and resolutions introduced in the 79th General assembly of Ohio. I9II.

Regulation of public utilities; a comparison of the New York and the Wisconsin public utilities bills. I9 I . 36 p.

Workmen's compensation or insurance against loss of wages arising out of industrial accidents, by J. H. Boyd. I9Ir. 49 p.

Organic law of Ohio and proposed amendments. I9I3.

Compulsory voting and absent voting, with bibliographies by $W$. ' $\Gamma$. Donaldson. I9r4.

Civil service laws of Ohio. Comp. by Legislative reference department. Published by direction of Board of library commissioners. I9I5. $70 \mathrm{p}$.

Report of the Committee for an investigation of finances of municipalities. Bulletin of the Ohio Legislative reference department. Feb. 3, I9I5. $4 \mathrm{I}$ p. incl. tables.

Road laws of Ohio, comp. by Legislative reference department. Published by direction of Board of library commissioners of Ohio. I9I5. xxxix, $335 \mathrm{p}$.

Laws of Ohio relative to legal advertising. I9I6. 


\section{LEGISLATIVE REFERENCE AND BILL-DRAFTING}

Finances of Ohio cities, debt and taxation. Bulletin of the Ohio Legislative refêrence department. Columbus, I9I7. 8I p. incl. tables.

\section{Pennsylvania: Legislative Reference Bureau. The Leg-} islative Reference Bureau of Pennsylvania, as at present constituted, was authorized by an act of April 27, 1909, ${ }^{1}$ as amended by the acts of April 2I, I9II, ${ }^{2}$ and May I4, I9I $5 .{ }^{3}$ The bureau was established primarily for the use and information of the members of the General Assembly, the heads of the several departments of the state government, and such other citizens of the commonwealth as may desire to consult the same.

Under the act creating the bureau it becomes the duty of the director and his assistants, upon request, to aid and assist the members of the General Assembly, the Governor, and the heads of the departments by advising as to bills and resolutions, and also to draft the same into proper form for presentation to the legislature. The bureau is also required to furnish to the members of the General Assembly, the Governor and the heads of the departments, full information upon all matters of public interest. It may neither urge nor oppose legislation nor suggest any bills for introduction. The purpose and aim of the bureau in the drafting of bills is to pay particular attention to the form, to make them readable and easily understood, to look into their constitutionality, both as to form and substance and their effect upon existing legislation. The bureau keeps a file and index of the bills introduced at each session.

The bureau prepares from time to time and publishes bulletins, pamphlets and circulars containing information collected by the bureau and such compilations of the laws of the state and of other states as are deemed of service to the state government.

An act approved May 20, $1913,{ }^{4}$ directed the bureau to examine the entire statute law of the commonwealth and to ascertain what laws and parts of laws have been repealed or

${ }^{1}$ Pennsylvania, Acts, 1909, p. 208.

${ }^{2}$ Pennsylvania, Acts, I9I I, p. 76.

Pennsylvania, Acts, 1915, p. 474.

- Pennsylvania, Acts, I9I3, p. 250. 


\section{EFFORTS FOR ADMINISTRATIVE REFORM}

which have become obsolete; and to prepare, for adoption or rejection by the General Assembly, compilations, by topics, of the existing general statutes. Subsequent acts approved May I4, I9I5 [Public Laws, I94] and May 3, I9I7 [Public Laws, 87] authorized the bureau to continue this work.

\section{PUBLICATIONS}

Bill drafting, by James McKirdy, assistant director. Harrisburg. I9I2. $22 \mathrm{p}$.

"A paper read at the annual meeting of the National association of state libraries, held at Ottawa, June, I9I2," p. 5. "List of works," p. I7-23.

Constitution of Pennsylvania, analytically indexed, and with index of prohibited legislation. I9I2. II8 p.

Liquor laws of Pennsylvania. Comp. by James McKirdy, assistant director. Harrisburg, C. E. Aughinbaugh, printer to the state, 1912. I p. $1 ., 46$ p.

Comprises only the general laws relating to the sale of liquors.

Special legislation in Pennsylvania, by James McKirdy, assistant director. Harrisburg, C. E. Aughinbaugh, printer to the state of Pennsylvania, I9I2. I2 p.

Preliminary draft of a bill codifying the existing general laws relating to boroughs. I9I4. $286 \mathrm{p}$.

$\longrightarrow$ Revised draft. 1915.288 p.

Preliminary draft of a bill codifying the existing general laws relating to corporations. I9I4. $382 \mathrm{p}$.

Preliminary draft of a bill consolidating the existing general laws relating to boroughs. 19I4. $242 \mathrm{p}$.

Preliminary draft of a bill consolidating the existing general laws relating to taxation. I9I4. $252 \mathrm{p}$.

Report on the codification of the statutes. John N. Moore, director. Harrisburg, W. S. Ray, state printer, I9I5. I2 p.

A compilation of the laws relating to the Board of public charities, with important provisions of the laws relating to the several state institutions and the rules and regulations of the Committee on lunacy, indexed. Prepared by John H. Fertig, esq., and Frank M. Hunter, esq., under the direction of James N. Moore, director. 1916. $260 \mathrm{p}$.

A compilation of the laws relating to juvenile courts and dependent, neglected, incorrigible and delinquent children. Prepared by John H. Fertig and S. Edward Hannestad, under the direction of James N. Moore, director. Harrisburg, Pa., W. S. Ray, state printer, I9I6. II2 $\mathrm{p}$.

Compilation of the general laws relating to townships. Legislative reference bureau. Prepared by John H. Fertig, esq., and Frank M. Hunter, esq., under the direction of James N. Moore, director. Harrisburg, Pa., W. S. Ray, state printer, I916. 322 p.

Constitutions of Pennsylvania. Constitution of the United States, analytically indexed and with index of legislation prohibited in 


\section{LEGISLATIVE REFERENCE AND BILL-DRAFTING}

Pennsylvania. Prepared by John H. Fertig, esq., and Frank M. Hunter, esq., under the direction of James N. Moore, director. Harrisburg, Pa., W. S. Ray, state printer, I9I6. 302 p.

\section{ARTICLE}

Watts, I. A. Work in the Pennsylvania legislative reference bureau. Law library journal, Jan., 1917, v. 9: 139-46.

\section{Rhode Island: State Library: Legislative Reference}

Bureau. This bureau is a branch of the Rhode Island State Library. It has its origin in an act approved April 23, 1907, which was amended by an act of April 30, 1908. ${ }^{2}$ As amended, the law provides that "there shall be in the state library, under the direction of the state librarian, a legislative reference bureau, which shall collect, arrange, and place on file, books, pamphlets, and other material relating to legislation, which shall prepare abstracts of laws in other states, and which shall present such other information as may be useful and necessary to the general assembly in the performance of its legislative duties."

The state library is operated primarily as a legislative library while the legislature is in session. There have been segregated from the main collection, for quick reference, the important books and pamphlets bearing on legislative questions and to these have been added other legislative reference material, all classified and indexed according to approved legislative reference bureau methods. The appropriations of the bureau have been increased from time to time to meet the needs of the service.

No provision has been made for the employment of draftsmen either under the legislature or under the legislative reference department of the state library. The state librarian and his assistants, however, render in an unofficial way, such assistance as they can in preparing bills for introduction. While there has never been authority granted for this purpose, the burden of this work has been placed upon the state library. During I9I7, the library prepared for the legislature 547 acts, resolutions, petitions and memorials.

\footnotetext{
${ }^{1}$ Rhode Island, Acts, 1907, No. I471, p. 93.

Rhode Island, Acts, I908, No. I 554, p. I 28.
} 


\section{EFFORTS FOR ADMINISTRATIVE REFORM}

\section{PUBLICATIONS}

Legislative reference bulletin [No. I] - Providence, 1907Contents.

No. I. The veto power in the several states. Comp. and annotated by Arthur C. Wyman and Grace M. Sherwood. 1907. $57 \mathrm{p}$.

No. 2. Automobile laws of the New England states, New York, New Jersey, and Pennsylvania. Comp. by Arthur C. Wyman. I908. I06 p.

No. 3. Summary of the general banking laws of the commercial states. Comp. by Grace M. Sherwood. I908. 334 p.

No. 4. Officers, boards and commissions of Rhode Island. Comp. by Henry E. Fowler and Grace M. Sherwood. I9II. $67 \mathrm{p}$.

No. 5. Employer's liability and workmen's compensation. By Edward A. Adams and William E. Sprackling. I9I2. $69 \mathrm{p}$.

No. 6. General constitutional and statutory provisions relative to suffrage. Comp. by Lowell Kendrick and Harold P. Salisbury. I9I2. 99 p.

No. 7. State commissions on economy and efficiency. Comp. by Chester C. Waters. I9I5. I5 p.

No. 8. Exercise of sanitary police powers in Rhode Island. By Lester Burrell Shippee. I916. $36 \mathrm{p}$.

Circular No. I. Rhode Island towns and cities. Expenditures for

highways and bridges, I898-1909. I9I I. 6 p.

\section{South Dakota: State Library: Division of Legislative} Reference. The Legislative Reference Division of the South Dakota State Library was created by an act approved February I8, I907. ${ }^{1}$ The state library with all its divisions, was placed under the supervision of the Free Library Commission by an act of February 19, 19: $3,{ }^{2}$ creating that commission. The act of 1907 directs the state librarian "to establish a division of legislative reference, in which he shall provide the reports of the various officers and boards of this state and as far as may be of other states, and such other material upon economic and sociological subjects as he may be able to provide, and shall index and classify the same and make the information therein available for the use of the state legislature, and shall, as required, provide for the use of members of the legislature, such information and assist in drafting bills and in every reasonable way make the division

${ }^{1}$ South Dakota, Acts, 1907, Ch. 185, p. 395.

"South Dakota, Acts, I913, Ch. 217, p. 300. 
useful in the preparation of legislation." A librarian has been actively in charge of this work since the enactment of this law. He shelves all the documentary material from other states of the Union, and adds such reference material as can be obtained without purchase. Between legislative sessions the librarian compiles digests on subjects of interest to legislators concerning laws of other states; secures material from other legislative reference agencies; and makes indexes of bills introduced and of other material.

The library drafts about one-half of the bills that are introduced into each session of the legislature.

\section{PURLICATIONS}

Bulletin No. I. Digest of governors' messages of [South Dakota] ed. by Thomas Askin, I910? 74, $6 \mathrm{p}$.

Bulletin No. 2. Parallel references, the Constitution-the constitutional debates, with digest to supreme court reports. I9Io. 79 p.

Bulletin No. 3. History of the initiative and referendum in South Dakota. Pierre? I9I6. 5 p.

Bulletin No. 4. Titles of laws. I9I6. 3 p.

Bulletin No. 5. Prisoners on public highways?

\section{Vermont: State Library: Legislative Reference Bureau.} The Legislative Reference Bureau was originally established by the act of January I2, I9 I I, ${ }^{1}$ under the supervision of the state library. No provision was then made for a bill-drafting service, but the rules of the legislature provided for a joint committee known as the "Revision Committee" to whom all bills were referred previous to their introduction, for correction as to phraseology, form, etc. An act of February 2I, I9I $3{ }^{2}$ amending the act of I9I0, provided for two officers known as "revisers of bills" to be appointed by the Governor and confirmed by the Senate. An act of February 3, I9I $5,^{3}$ placed the power of appointment in the hands of the President of the Senate and the Speaker of the House with the deciding vote in the Chief Justice, when necessary, and changed the title to "legislative draftsmen." This amendment also provided that "the legislative draftsmen shall per-

\footnotetext{
Vermont, Acts, I9Io, No. 9, p. 7.

Vermont, Acts, I912, No. I4, p. I4.

${ }^{3}$ Vermont, Acts, I915, No. Io, p. 74.
} 


\section{EFFORTS FOR ADMINISTRATIVE REFORM}

form their duties in the office of, and in connection with, the Legislative Reference Bureau in the State Library," and prescribed their duties to be to "give assistance to members and committees in the drafting of bills, resolutions and amendments, if so requested," and prohibited them from opposing or urging legislation or the election of any officer by the General Assembly. It further provided that "the legislative draftsmen shall perform for the Senate and House of Representatives all the duties of a Committee on Revision of Bills, except when the joint rules of the Senate and House of Representatives provide that such Committee be otherwise constituted."

An act approved March 2I, I9I $7,{ }^{1}$ makes it a duty of the legislative reference librarian to make and publish condensed statements of the monthly reports which all state departments and other state institutions are required to make to the Board of Control.

\section{PUBLICATIONS}

Finding list, Legislative reference department. IgI2. II I p.

Direct primaries. Montpelier, Vt., I9I4. 8 p., I fold. 1

The state's work. Pt. I. An analysis of the state boards, officers, commissions and institutions Pt. II. A brief digest of the state department reports for the biennial period ending June 30, I9I6. Comp. by the Legislative reference bureau. [Montpelier] I9I6. $60 \mathrm{p}$.

For publications before February, I913, see Vermont. State library. Legislative reference department.

Virginia: Legislative Reference Bureau. The Legislative Reference Bureau of Virginia was created by an act approved March 2I, I9I $4 .^{2}$ It is in charge of a director who is appointed by the Governor with the approval of the Senate. The organic act makes the usual provision for the collection and classification of material and the employment of the necessary force of assistants, draftsmen and clerks. The act further provides that upon the request of the Governor or any member of the General Assembly, the bureau shall:

Draft or aid in drafting legislative bills or resolutions and amendments thereto; advise as to the constitutionality or prob-

${ }^{1}$ Vermont, Acts, 19i7, No. 32, p. 27.

${ }^{2}$ Virginia, Acts, 1914, Ch. I94, p. 3 I4. 
able legal effect of proposed legislation; prepare summaries of existing laws affected by proposed legislation, compilations of laws in other states or countries relating to the subject matter of such legislation, and statements of the operation and effect of such laws; make researches and examinations as to any subject of proposed legislation.

\section{PUBLICATIONS}

Legislative reference lists.

I9I0. Bank examiners. City charters. Municipal home rule. Fee system. Juvenile courts. Oyster industry. Primaries. Liquor question. Protection of birds. Taxation. Tuberculosis.

A brief history of taxation in Virginia, by Edgar Sydenstricker . . . Richmond, 1915. 66 p.

Legislation in Virginia, I9I4. Comp. by Lewis Machen, director. Richmond, I9I5. I3 p.

A summary of tax systems, boards, and methods of equalization of the several states. Comp. by Lewis H. Machen, director. Richmond, I9I5. $29 \mathrm{p}$.

A condensation of portions of a bulletin recently issued by the U. S. Burcau of the census, supplemented by reference to bulletins of the New York tax reform association and, in some instances, by inspection of the statutes. cf. Explanation, p. [2]

Extracts from liquor laws of prohibition states. Comp. under the direction of Lewis Machen, director. I9I6. 264 p.

Department of archives and history. Legislative reference library. Charleston, W. Va., Lovett printing co., n.d. [2] p.

West Virginia: Department of Archives and History: Legislative Reference Section. While there is no law in West Virginia creating a legislative reference or bill-drafting service, and no specific appropriation has been made for one, the Governor in I9I 3 requested the state historian and archivist to organize a Legislative Reference Section in the library of the Department of Archives and History. The material of the library has been specially arranged and made available for purposes of legislative reference. The section is gathering all information that is likely to be of use to the legislative and administrative branches of the state government. This material is at the command of members of the legislature, administrative officers and other citizens.

The Department of Archives has undertaken, to a limited extent, the preparation of tentative drafts of legislative meas- 


\section{EFFORTS FOR ADMINISTRATIVE REFORM}

ures in accordance with specifications submitted, but it is not the intention of the present librarian to continue this service.

\section{Wisconsin: Free Library Commission: Legislative Refer-} ence Department. The Legislative Reference Department of the Wisconsin Library Commission was established in a small way in I90I under authority of an act approved April I3, 1901. ${ }^{1}$ Subsequent laws were enacted ${ }^{2}$ on May 13, I903, May 8, I905, July 9, 1907, August 9, I9I3 and June I4, I9I7, further defining the duties of the commission with respect to the legislative reference and bill-drafting work and making specific appropriation therefor. Provision for the employment of a corps of draftsmen for the bill-drafting service was first made in the act of I9I7. This service is maintained distinct from, but in close coöperation with, the legislative reference work, the two services being coördinate. No legal provision has been made for any particular form of organization, for a director, or for the tenure of office of those employed in the service, all this being left to the discretion of the Free Library Commission.

At present the duties of the Free Library Commission with reference to the Legislative Reference Department as defined by law are as follows:

To maintain in the state capitol, for the use and information of the legislature, the several state departments, and such other citizens as may desire to consult the same, a legislative reference room and a small working library... of the several public documents of this and other states, and to purchase for said library standard works of use and reference. The said commission may also collect, summarize and index information of a legislative nature relating to legislation of foreign countries, of states of this country, the federal government and municipalities, [and] make such investigations into statute law, legislative and governmental institutions as will aid the legislature to perform its duties in the most efficient and economical manner.

${ }^{1}$ Wisconsin, Acts, 190I. Sec. 373 f, Ch. I68, p. 213.

${ }^{2}$ Wisconsin, Acts, 1903, Ch. I77, p. 384; Wisconsin, Acts, 1905, Ch. 177, p. 263; Wisconsin, Acts, 1907, Ch. 508, p. 70; Wisconsin, Acts, 1913, Ch. 772, p. I269; Wisconsin, Acts, I917, Ch. 425, p. 690. 
With regard to bill drafting, the law provides that "the free library commission shall employ, during each legislative session and the two months next preceding each session, draftsmen and such help as may be necessary for the drafting of bills." An annual appropriation of $\$ 2 \mathrm{I}, 800$ is made "for carrying out the powers, duties and functions provided by law for the legislative reference department." The act of 1917 appropriated $\$ 6,000$ as "an emergency fund for the execution of the functions of the legislative reference library in preparing for special and regular sessions of the legislature and during the continuance of such sessions."

\section{PUBLICATIONS}

Comparative legislation bulletin, No. I-Madison, Ig06-

Contents.

No. I. Railway coemployment, by M. A. Schaffner. I905. $27 \mathrm{p}$.

No. 2. Lobbying, by M. A. Schaffner. 1909. 31 p.

No. 3. Corrupt practices at elections: contributions and expenditures. 1906. $35 \mathrm{p}$.

No. 4. Exemption of wages, by M. A. Schaffner. Igo6. $39 \mathrm{p}$.

No. 5. Municipal electric lighting, by E. B. Smith. Igo6. $22 \mathrm{p}$.

No. 6. Trust company reserves, by M. A. Schaffner. I906. $24 \mathrm{p}$.

No. 7. Taxation of trust companies, by M. A. Schaffner. I906. I9 p.

No. 8. Municipal gas lighting, by E. S. Bradford. 1906. I8 p.

No. 9. Boycotting, by G. G. Huebner. 1906. 26 p.

No. Io. Blacklisting, by G. G. Huebner. Ig06. 22 p.

No. II. The initiative and referendum: state legislation, by M. A. Schaffner. 1907.

No. I2. The recall, by M. A. Schaffner. 1906. 21 p.

No. 13. Primary elections. The test of party affiliation, by M. A. Schaffner. 1908. 37 p.

No. I4. Proportional representation, by R. E. Curtis. I908. $29 \mathrm{p}$.

No. 15. Juvenile courts, by S. K. Hornbeck. I908. 4I p.

No. I6. Telephone Interchange of service, by Laura Scott. I908. $20 \mathrm{p}$.

No. I7. Mortgage taxation, by R. A. Campbell. I908. 60 p.

No. I8. Municipal home rule charters, by M. A. Schaffner. 1908. $38 \mathrm{p}$.

No. 19. Tenement house legislation, state and local, by F. H. MacGregor. I909. 70 p.

No. 20. Accident insurance for working men, by Reuben McKitrik. I909. 70 p. 


\section{EFFORTS FOR ADMINISTRATIVE REFORM}

No. 2I. The initiative and referendum (No. II, rev.), by C. H. Talbot. I9I0. $43 \mathrm{p}$.

No. 22. Certified public accountant, by Laura Scott. I9Io. 44 p.

No. 23. Corrupt practices at elections, No. 3, revised by S. G. Lowrie. I9II. 86 p.

No. 24. State legislation concerning tuberculosis, by L. F. Tiefenthaler. I9II.

No. 25. The initiative and referendum: state legislation, by C. H. Talbot. I9I3.

Legislative reference list No. I. State regulation.

No. 2. State aid for roads.

No. 3. State civil service.

\section{ARTICLES}

Dodgeon, M. S. The Wisconsin legislative library. Yale review, Nov., 1907, v. 16: 288-95.

Flower, E. Sounding the retreat. illus. Harper's Weekly, May I, I915, v. $60: 417-8$.

Massachusetts. Committee to examine the Legislative reference bureau and bill drafting department of Wisconsin. Report to the governor of the commonwealth and the Board of trustees of the State library, of the committee which recently visited Madison, Wisconsin, to examine the Legislative reference bureau and bill drafting department. [Boston, I9I5] [4] $\mathrm{p}$.

Wisconsin. Free library commission. Legislative reference department. [2d ed.] Madison, Wis., I9I I. 30 p. (Wisconsin free library commission, Madison . . . Circular of information, No. 6.) "References," p. 27-28.

"Publications of the Commission," p. 29-30.

Published also in Massachusetts. State library. Sixth annual report for I9I5. Boston, I9I5, p. I9-23. 


\section{CHAPTER XIV}

\section{LEGISLATIVE REFERENCE SERVICES}

\section{United States: Library of Congress: Legislative Refer-}

ence Division. After efforts extending over several years there was secured from Congress in I9I4 an appropriation: "To enable the Librarian of Congress to employ competent persons to prepare such indexes, digests, and compilations of law as may be required for Congress and other official use pursuant to the Act approved June 30, 1906, \$25,000.” 1

This item has been repeated in the appropriation acts for subsequent years, the language in subsequent years being changed to read as follows:

Legislative Reference: To enable the Librarian of Congress to employ competent persons to gather, classify and make available in translations, indexes, digests, compilations and bulletins, and otherwise data for or bearing upon legislation and to render such data serviceable to Congress and committees and members thereof, $\$ 25,000$.

In his annual report for the year ending June 30, 1915, the Librarian of Congress, describing the actual demands made upon the Legislative Reference Division which he had established, said that they might be grouped as follows: "For digests or compilations of federal or state statute or constitutional law on various subjects; for comparative studies, compilations, abstracts or translations of foreign law or decrees on various subjects; for compilations on certain ques-

${ }^{1}$ Legislative, executive and judicial appropriation act for fiscal year ending June 30, 1915, approved July I6, I9I4.

The provision of law referred to was the original authorization, contained in the sundry civil appropriation act, for the preparation by the Law Librarian under direction of the Librarian of Congress, of a new index to the Statutes at Large, and such other indexes, digests and compilations of law as might be required for Congress. 
tions of legislative procedure-domestic and foreign; for translations and compilations on certain subjects in international law; for digests and compilations on powers of the executive-in Canada, France, and Germany-over the tariff; for statistical information on some nineteen subjects, foreign and domestic; for extracts (furnished in the form of photostat reproductions) of various articles in newspapers or periodicals; for lists of bills introduced on certain subjects; for memoranda on bills pending, e. g., the construction of certain words or phrases, the history of previous legislation on the same subject, precedents from other jurisdictions, or the record of subjects within the field of two or more committees; for bibliographic memoranda on certain subjects; and for reports or memoranda involving miscellaneous reference work in coöperation with other Divisions of the Library."

The Librarian comments on the fact that though the service as legalized contained no provision for bill drafting, some requests for aid in this respect were received and informally given.

To this division was turned over the task of continuing the preparation on cards of an index to the federal statutes which had been brought down through the year 1907 in the two volumes published in 1908 and I9I I.

In his report for the year ending June 30, 1916 , the Librarian of Congress calls attention to the fact that the purpose for which the appropriation for the year had been granted had been broadened and made to read: "To gather, classify, and make available, in translations, indexes, digests, compilations, and bulletins, and otherwise, data for or bearing upon legislation, and to render such data serviceable to Congress and committees and Members thereof." For these purposes $\$ 25$,ooo was made available.

With the extension of its work, it became necessary to organize a special legal section of the division to which were referred-

I. The preparation of digests and compilations of statutes, statutory rules and orders, constitutional provisions and court decisions in any jurisdiction, United States, state or foreign, including comparative legislative studies. 


\section{LEGISLATIVE REFERENCE SERVICES}

2. The preparation of briefs on the constitutionality of proposed legislation and on the judicial construction of words and phrases and other technical matters in the text of bills and resolutions, introduced or intended to be introduced in Congress.

3. Any indexing of the United States, state and foreign legislation which might be undertaken from time to time.

4. The preparation of digests and compilations on international law topics from treaties, conventions, proceedings of conferences, and from American and foreign international law writers.

In his report for the year ending June 30, 1916 , the Librarian of Congress gives a detailed statement of the many manuscript reports made under the foregoing heads upon request of Members of Congress. An account is also given of the compilation of United States public land laws which had been ordered made during the session of I9I4-I9I5 by the House Committee on Public Lands, and which was reported as ready for publication. ${ }^{1}$

In his report for the year ending June 30, I9I7, the $\mathrm{Li}$ brarian of Congress states that during the eighteen months of its existence some twenty-three hundred inquiries for information by Members of Congress had been received and answered. He notes, however, that "in relatively few cases are the results of legislative reference made available in their original form to a wider public. Some instances of publication in the Congressional Record and committee hearings, or separately as Senate documents and committee prints, have been noted above. The latter method presents the compilation or digest in a form much more convenient for use than the former plan, which buries it in a mass of other material in which it is difficult to find when wanted without an exact reference to the page where it occurs. A more satisfactory arrangement than either of these would be publication by the Library of Congress as separate legislative reference bulle-

${ }^{1}$ Independently of this compilation is one prepared by $\mathrm{Mr}$. J. W. Keener of the General Land Office at the order of the Senate Committee on Public Lands, - a work, however, less complete and less ambitious in scope than that prepared by the Legislative Reference Division. 


\section{EFFORTS FOR ADMINISTRATIVE REFORM}

tins. To enable this to be done, however, an addition to the printing allotment would be required."

\section{PUBLICATIONS}

Note: The Legislative reference division has issued no publications. The annual reports of its work are to be found in the reports of the Librarian of Congress for the years 1915 to date. A number of its compilations have been ordered printed by Congress as Senate or House documents, and others have been incorporated in the Congressional record. A few titles are listed below.

Foreign legislation on the merchant marine. Letter before the Committee on commerce, United States Senate, Sixty-third Congress, third session, transmitting certain material which the Legislative reference division of the Library of Congress has gathered relating to foreign legislation on the merchant marine. Printed for the use of the Committee on commerce. Washington, Govt. print. off., I9I5. $3 \mathrm{I} \mathrm{p}$.

Limitations on campaign expenditures by the political party committees; also of candidates for the offices of United States senator and representative in Congress, under state laws in effect IgI6. Prepared in the Legislative reference division, Library of Congress ... Washington, Govt. print. off., I9I6. I4 p. incl. tables. (64th Cong., 2d sess. Senate Doc. 640.)

Absent voting. Summary of statutes and constitutional provisions in force in the various states, November, 1916. Prepared in the Legislative reference division, Library of Congress .... Washington, Govt. print. off., I9I7. I6 p. (64th Cong., 2d sess. Senate Doc. 659.)

Exemption from military service in Great Britain. Statutory provisions and regulations relative to tribunals and certificates of exemption under the military service acts, with a digest of appealed cases. Comp. in the Legislative reference division, " $\mathrm{Li}$ brary of Congress .... Washington, Govt. print. off., 1917. 45 p. ([U. S.] 65th Cong., Ist sess. Senate Doc. 62.)

Restriction on aliens in Great Britain, France, Italy, Germany, Austria-Hungary, since the beginning of the European war [comp. by the Legislative reference bureau, Library of Congress. (In U. S. Congress. House Committee on immigration and naturalization. Registration of aliens. Hearings . . on H. R. 20936 ... Feb. 28, 1917. Washington, 1917. p. 4-I8.)

Trading with the enemy: an article upon the measures adopted by Germany in retaliation for those promulgated by other nations, by Theo. H. Thiesing [Legislative reference division. Library of Congress] .... Washington, Govt. print., I9I7. 7 p. ([U. S.] 65th Cong., Ist sess. Senate Doc. I07.)

Transfer of flag. Extracts from the proceedings of the International naval conference, London, I908, and of the Institute of international law, I882 and I9I3. Tr. by the Legislative reference bureau, Library of Congress. Printed for the use of the Committee on foreign relations. Washington, Govt. print. off., I9I5. $23 \mathrm{p}$. 


\section{LEGISLATIVE REFERENCE SERVICES}

Government control of railways in Great Britain. Memoranda submitted to the Committee on interstate commerce, United States Senate. Sixty-fifth Congress, Second session relative to the government control of railways in Great Britain in its financial aspects and in relation to railway employees. Washington, Govt. print. off., I9I8. $56 \mathrm{p}$.

\section{California: State Library: Legislative Reference Depart-} ment. The Legislative Reference Department of the State Library was created in December, 1904. There is no specific provision of law creating this department, its creation being effected under general powers given the state library to create subordinate departments. It does not duplicate the work of the Legislative Counsel Bureau, ${ }^{1}$ which, while it performs some of the duties of a legislative reference bureau, is primarily a bill-drafting service.

\section{PUBLICATIONS}

Bulletin No. I. Hints on drawing legislative bills. Dec. I, I908. I2 $\mathrm{p}$.

Bulletin No. 2. River improvement laws in other states and countries. Dec. 29, I908. 29 p.

\section{Connecticut: State Library: Legislative Reference De-} partment. The legislative reference work of the Connecticut State Library is one of the functions of the state librarian. There has been no special act creating a legislative reference department other than by making a special appropriation of $\$ 5,000$ biennially since 1907 , at which time the state library work was especially increased along this line. The legislative reference work has been conducted since that time by the state librarian and a number of trained assistants. It is a reference library not only for legislators but also for the Supreme Court, state officers and the several state departments.

The special work done in the Legislative Reference Department consists of maintaining a well-classified and very full collection of official reports and treatises upon the various topics before the several General Assemblies, made accessible through a complete card catalogue. In addition to

${ }^{1}$ See p. 329. 


\section{EFFORTS FOR ADMINISTRATIVE REFORM}

the printed material which is secured from all sections of the country and from foreign countries, the department maintains a file of the printed bills from about twenty-five states, showing the proposed legislation in those states.

The department makes and maintains a photostat copy of every bill, resolution and petition introduced into the General Assembly. As no bills are printed in Connecticut until favorably reported by the committees to which they have been referred, the photostat copies, made almost immediately when introduced, are invaluable. The library maintains a series of cards covering each such bill, resolution and petition, showing its number, when and by whom introduced, to what committee referred, when hearings were advertised, when and what report was made upon it, action in each house and, if passed, when signed by the Governor and its position in the public or special laws. Another set of cards shows the several sections of the Connecticut revised statutes. Whenever these sections are amended or repealed, this additional information is entered on a card which is filed with the main card. Thus the material for a revision of the statutes is always at hand.

Transcripts of the stenographers' notes at the hearings held before the several committees are kept on file. These transcripts, after each session, are thoroughly indexed and are bound, thus making accessible to future General Assemblies and to judges of the courts, the intention and purpose of each bill as advocated at these hearings.

Special reference lists upon various topics and special investigations along definite lines are made from time to time when requested by state officials.

\section{PUBLICATIONS}

Bulletin No. I. List of references to material on employer's liability and workmen's compensation. 1913. $27 \mathrm{p}$.

\section{Reports}

Report on legislative reference work. (In Connecticut state library. Report of the state librarian to the Governor, 1909. Hartford, 1913-date.)

Georgia: State Library: Legislative Reference Department. A Legislative Reference Department in connection 


\section{LEGISLATIVE REFERENCE SERVICES}

with the State Library, was created by an act approved August I2, I914. ${ }^{1}$ Its object, as expressed in the act, is: "To gather and make available such information as shall aid the members of the legislature and the several state departments in the discharge of their duties and to serve such other citizens as may desire to consult them." The duties prescribed are to "collect, arrange, classify and index books, pamphlets and other material relating to legislation;... prepare abstracts of laws of other states and countries, and ... make such indexes of the legislative and administrative records of this state both current and past, as to make access and reference thereto easy and sure."

\section{Reports}

Reports for 1915-date. (In Georgia. State library. Annual report, I9I5-date.)

\section{Iowa: State Library: Law and Legislative Reference} Department. A Legislative Reference Department is in operation in connection with the State Library. Section 288 Ic, chapter I7, of the supplement to the code I9I3 has the following provision: "There shall be annually appropriated . . . the sum of six thousand dollars for the use of the law department and legislative reference bureau." Provision is also made for "one legislative and general reference assistant who shall be under the direction of the assistant to the State Librarian."

\section{PUBLICATIONS}

Selected list of references on the valuation of public service corporations.

\section{Maine: State Library: Legislative Reference Bureau.} Early in I9I6 the state librarian was authorized by the Governor and council to employ a legislative reference clerk, but no special appropriation or authorization was made therefor.

On March 29, I9I7, however, an act was approved ${ }^{2}$ authorizing the state librarian "to establish in the state library a

${ }^{2}$ Georgia, Acts, 1914, No. 397, p. 137.

2 Maine, Acts, I917, p. 97. 


\section{EFFORTS FOR ADMINISTRATIVE REFORM}

legislative reference bureau which shall collect, arrange and place on file books, pamphlets and other material relating to legislation, shall prepare abstracts of laws in other states and present such other information as may be useful and necessary to the legislature." It authorizes the state librarian to employ such assistance and incur such expense as may be necessary for the proper administration of the bureau.

\section{Massachusetts: State Library: Legislative Reference De-} partment. Since 1892 provision has been made in the appropriation acts for the State Library "for preparing an index to current events and such other matters contained in the newspapers of the day, as may be deemed important by the trustees and librarian." In an appropriation act of I9I0, ${ }^{1}$ provision was made for a "card index of comparative legislation." By this provision and the initiative of the state librarian a Legislative Reference Department has been built up in the State Library, although no specific legislative provision has been made for such an agency. In the reference department, which is under the immediate direction of a reference assistant, the activities are such that in the course of legislative sessions it is not infrequently the case that all members of the regular state library staff are busy in research work and in answering questions of a legislative character. The department keeps up to date a current periodical card index, a current events index to the newspapers, an index to the Governors' messages and a card catalogue of Massachusetts legislators. These are in constant use. The library is rich in its collections of material in the field of legislation. A recataloging of the State Library is now in progress.

\section{New Jersey: State Library: Legislative Reference Depart-} ment. The legislative reference service in New Jersey is furnished by a department of the State Library. An act approved March I8, I9I $4,{ }^{2}$ provides that: "It shall be the duty of the State Librarian to collect and keep constantly up to date . . such information and material as will furnish the fullest information practicable upon all matters pertaining to cur-

${ }^{1}$ Massachusetts, Acts, 1910, Ch. 75.

${ }^{2}$ New Jersey, Acts, I9i4, Ch. 29, p. 44. 


\section{LEGISLATIVE REFERENCE SERVICES}

rent or proposed legislation or any legislative or administrative problems, and to prepare and submit digests of such information and material upon request of any legislative committee or any member of the Legislature."

\section{PUBLICATIONS}

Descriptive list of laws and joint resolutions enacted by the state of New Jersey, legislative session, I917. Comp. by John P. Dullard, state librarian. Union Hill, N. J., Hudson printing company, I917. $16 \mathrm{p}$.

Prepared by the Legislative reference department of the New Jersey state library. cf. p. [2].

New York: State Library: Legislative Reference Section. In New York State there is a Legislative Reference Section of the State Library, and a legislative library in the Capitol. The Legislative Reference Section of the State Library was established in 1890 by an order of the director of the State Library, and is, therefore, the oldest legislative reference service in the United States. Its work is conducted as a part of the activities of the State Library, and it has a staff subject to the supervision of the director of the State Library. It performs legislative reference work for legislators, state and government departments, officers and students. Among its activities are the indexing and editing of the official edition of the New York session laws; the preparation of legislative bulletins; the receiving, checking, cataloging and shelving or filing of state, municipal, federal and foreign documents and other material. A very considerable part of the activities of the section consists of research work and the preparation of special memoranda for legislators, state officers and other important organizations.

In addition to this library the state maintains, as a district organization, a bill-drafting service, account of which is given in the following chapter. ${ }^{1}$

${ }^{2}$ See p. 366 . 


\section{EFFORTS FOR ADMINISTRATIVE REFORM}

\section{PUBLICATIONS}

Legislative bulletins. ${ }^{1}$ Albany, I89I-

While these bulletins bear a single series of serial numbers according to date of publication, most of them fall into several distinct series, as follows:

Comparative summary and index of state legislation
No. I, I89o, p. I-84
No. 2, I891, p. 85-226
No. I5, IgoI, p. 813-1232
No. 3 , 1892, p. $227-294$
No. 4 , 1893 , p. $295-45^{2}$
No. I8, 1902, p. 413-696
No. 5,1894, p. $453-55^{\circ}$
No. 2I, 1903, p. 267-774
No. 24, I904, p.

Legislation by states

No. 6, I895, p. I-312

No. 7 , 1896, p. 313-426

No. 9 , I 897 , p. $485-73^{8}$

No. 10, 1898, p. 739-912

No. II, 1899, p. 1-398

No. 13, 1900, p. 439-614

Review of legislation

No. I6, I90I, p. I-250

No. 19, 1902, p. 697-912

No. 29, 1905, 334 p.

No. 22, 1903 ,

No. 25, 1904,

No. 33, 1906, 249 p.

No. 39, I907-8, 475 p.

Index of legislation

No. 28,1905

No. 32,1906

No. 36,1907

No. 38, 1908, 264 p.

Digest of governors' messages

No. 17, 1902, p. 251-412

No. 20, 1903, p. I-266

No. 23, 1904

No. 27,1905

No. 31, 1906, 79 p.

No. 35, 1907

No. 37,1908

The following numbers do not fall within any of the above series:

No. 8. State finance statistics, 1890 and 1895 . p. 427-82.

No. 12. Trend of legislation in the United States, by R. H. Whitten. I900. p. $399-438$.

No. 14. Taxation of corporations in New York, Massachusetts, Pennsylvania and New Jersey, by R. H. Whitten. I90I. p. 615-812.

No. 26. Index of Governors' messages, I777-1901, by M. G. Wyer and C. E. Grover.

No. 30. Legislative reference lists. I906. 39 p. [Lists on life insurance, direct nominations, employment of blind and inheritance tax.]

No. 34. A summary of the compulsory attendance and child labor laws of the states and territories of the United States. 1907. II $\mathrm{p}$.

${ }^{1}$ Beginning with No. 20 (1903) the three or more bulletins of each year are also issued in one volume under title Yearbook of Legislation. 


\section{LEGISLATIVE REFERENCE SERVICES}

No. 40. American ballot laws, I888-ı I0, by A. C. Luddington. I9II. $220 \mathrm{p}$.

No. 4I. Mothers' pension legislation in New York and other states, by W. E. Hannan. I9I6. 4I p. fold. table.

No. 42. Property exempt from taxation in the forty-eight states, by W. E. Hannan. I9I6. $239 \mathrm{p}$.

Partial list of questions that were submitted to the Legislative reference section of the State library and upon which investigations were conducted and data prepared for various members of the legislative session of I9I7. [Albany] 1918. $8 \mathrm{p}$.

Licensing and regulation of bill board or outdoor advertising. Albany, 1918. $19 \mathrm{p}$.

Ordinances regulating the dimming of headlights in cities of the United States. I9I8. 37 p.

New York: Legislative Library. The Legislative Library at the Capitol is organized by virtue of an act approved May 3 , 1915, ${ }^{1}$ as amended by an act approved June $1,1917 .{ }^{2}$ Its principal function is the collection of documents and laws of New York State. It does no research work.

Oregon: State Library. In Oregon no specific provision has been made for a legislative reference bureau, but since I9I 3 the state librarian is required by law to render such service. The Oregon State Library, however, had been performing legislative reference work since 1905 without special authorization. An act approved February 25, 191 $3,{ }^{3}$ relating to the State Library provides, among other duties of the state librarian, that he shall "collect and index those public documents which shall be of service to state boards, officials, and commissioners, and for reference work for the members of the legislature for investigation of public questions." No specific mention is made of a legislative reference bureau. The Oregon State Library has done legislative reference work since 1905, although it has no separate department for this purpose.

Texas State Library: Legislative Reference Section. An act of March 19, 1909,, ${ }^{4}$ creating the Texas Library and His-

${ }^{1}$ New York, Acts, I915, Ch. 483, p. 1447.

"New York, Acts, I917, Ch. 715, p. 2309.

${ }^{3}$ Oregon, Acts, I9I 3, Ch. I49, p. 263.

Texas, Acts, I909, Ch. 70, p. I26. 


\section{EFFORTS FOR ADMINISTRATIVE REFORM}

tory Commission provided for a Legislative Reference Section, making the usual provisions respecting the materials to be collected, indexed and classified and providing for the appointment of an assistant librarian to conduct the work of the section. It also provided that this assistant librarian "shall give the members of the legislature such aid and assistance in the drafting of bills and resolutions as may be asked."

The legislature of I9I I cut out the appropriation for the salary of this assistant librarian, and until the session of I9I 5 no such appropriation was made. The work was continued nevertheless. In I9I3 a representative of the University of Texas took charge of the work, and in 19I 5 the library used a stenographer's salary to pay for an assistant to do the legislative reference work. The legislature of I9I 5 made appropriations for the salary of a legislative reference librarian and for conducting the work. The legislature of I9r7 cut out the latter but made a salary appropriation.

Owing to lack of funds very little bill drafting has been attempted and none will be undertaken for the legislature of igig.

\section{PUBLICATIONS}

Bulletin No. I. Finding list of books prepared by J. B. Kaiser. I9I I. $5^{\mathrm{I}} \mathrm{p}$.

Bulletin No. 2. Subject index to the bills and resolutions of the regular session of the thirty-fourth Legislature, prepared by J. F. Marron. [1915]

The legislative reference bureau as a bill revising agency, by J. F. Marron, ... [Austin? 19r6] [10] p.

Prepared for the Conference on bill drafting at Washington, December 3I, I9I 5 .

Reprinted from Special libraries, March, I9I6. 


\section{CHAPTER XV}

\section{BILL-DRAFTING SERVICES}

Connecticut. In Connecticut the bill-drafting service is performed by the clerk of bills, an officer of the General Assembly. An act approved January 22, I90I, ${ }^{1}$ provides that "the clerk of bills shall assist members of the General Assembly in drafting bills for public acts and resolutions of a public nature, and prepare amendments to or substitutes for bills or resolutions at the request of committees. Every bill or resolution favorably acted upon by any committee of the General Assembly shall, before being reported to either branch thereof, be first submitted to the clerk of bills, who shall examine such bill or resolution, in respect to its form, for the purpose of avoiding repetitions and unconstitutional provisions, and insuring accuracy in text and references, clearness and conciseness in the phraseology and to the consistency of statutes. He shall return to the committee submitting it any bill or resolution that is not in correct form with such corrections as he may propose in the form of a substitute or as amendments."

The clerk of bills, and the engrossing clerk, who supervises the printing and engrossing of bills and advises the Committee on Engrossed Bills of needed corrections, are elected at the beginning of each session by the Joint Committee on Judiciary and on Engrossed Bills acting jointly. In practice, a regular succession has been established as the normal arrangement. The assistant clerk of the House is promoted to be clerk of the House at the next session, and becomes clerk of the Senate two years later. At the following session he is elected clerk of bills, and two years later, engrossing clerk. This succession may be interrupted by political changes. In the last four biennial messages the governors have strongly

${ }^{1}$ Connecticut, Acts, I90I, Ch. I, Sec. 2, 3, 4. 


\section{EFFORTS FOR ADMINISTRATIVE REFORM}

urged that the position of clerk of bills be made permanent, and that the best available draftsmen should be procured for the position, but the legislature has not yet taken such action.

Massachusetts. Assistance in the drafting of bills to members and others is provided for by the Committee on Rules of each branch of the General Court. In the Senate, rules 20 and $2 \mathrm{I}$ provide that the committee shall examine all bills, etc., intended for introduction for the purpose of ascertaining: (I) whether the legislation proposed is plainly and specifically stated or already provided for; (2) whether such bills, etc., are in proper form; and (3) that compliance has been had with the rules of the Senate and the joint rules of the two branches. But the committee "shall make no change in the substance or form of any matter referred to them without the consent of the member depositing the same." Rule 33 provides that "bills and resolves when ordered to a third reading, shall be referred to the Committee on Bills in the Third Reading, whose duty it shall be to examine and correct them, for the purpose of avoiding repetitions and unconstitutional provisions, and of insuring accuracy in the text and references and consistency with the language of existing statutes; but in any change in the sense or legal effect, or any material change in construction, shall be reported to the Senate as an amendment." At the beginning of each session an order is adopted: "That the Committee on Rules be authorized to employ clerical assistance." A similar arrangement exists in the House of Representatives with the difference that the duties assigned to the Committee on Rules are specified in the order adopted at the beginning of each session and not in the rules of the House.

New York. The bill-drafting service in New York State is in the hands of the Legislative Bill Drafting Commission consisting of three commissioners appointed by the temporary President of the Senate and the Speaker of the General Assembly. The office of the commission is at the State Capitol and is required to be open from September I to the close of the session. The duties prescribed in the legislative act of 
February I7, 1909, ${ }^{1}$ as amended by acts approved December 12, 191 $3,^{2}$ and March 9, 1916, ${ }^{3}$ are: "I. To maintain an office in the state capitol . . . which shall be open from September I to the close of the annual legislative session, and for such further time as the temporary president of the Senate and the speaker of the assembly shall direct. 2. Draft or aid in drafting legislative bills and resolutions and amendments thereto upon the request of a member or committee of the legislature or of a state department, commission, board or officer. 3. Advise as to constitutionality, consistency or effect of proposed legislation, upon request of a member or committee of the legislature. 4. Make researches and examinations as to any subjects or proposed legislation upon request of either house or of a committee of the legislature. 5. Examine the general laws and report to the legislature such amendments to the consolidated laws as the commission deems advisable for the purpose of including therein independent general statutes."

An act approved May 3, I9I $7,{ }^{4}$ provides for the preparation, by the Bill Drafting Commission, of an index of statutes and makes appropriation therefor.

Account has already been given of the legislative reference libraries maintained by New York State. ${ }^{5}$

\section{New York: Columbia University: Legislative Drafting} Bureau. ${ }^{\circ}$ The Legislative Drafting Research Fund was organized at Columbia University in the spring of I9 I following the acceptance by the board of trustees of the university of a proposal to donate not less than $\$ I_{5}, 000$ annually for five years for research work in legislation and public adminis-

${ }^{1}$ New York, Consolidated Laws, 1909, Ch. 37, Sec. 24.

2 New York, Acts, I9I3, Ch. 812, p. 2273.

New York, Acts, I916, Ch. 32, p. 55.

New York, Acts, I9I7, Ch. 332, p. III4.

See p. 36r.

- This is a reproduction of an article published in Columbia Alumni News, November 26, I9I 5, by Dr. Thomas I. Parkinson, Director of the Legislative Drafting Bureau. Since this article was written the fund has continued the preparation for the American Bar Association of its annual review of legislation and has been active in aiding public and private organizations in the prcparation and drafting of legislation. 


\section{EFFORTS FOR ADMINISTRATIVE REFORM}

tration. ${ }^{1}$ Seven men, all law school graduates, are devoting their entire time to the work, which is conducted under the supervision of an administrative board consisting of John Bassett Moore, chairman; Harlan F. Stone, Dean of the Law School, and Joseph P. Chamberlain.

The primary purpose of the fund is research in legislation and administration. This involves the study of technical legal problems such as constitutional limitations on legislative power, the rules for construction of statutes and the force and effect of the existing statute or common law which it is proposed to limit or extend by new legislation. It involves also the study of administrative organization and procedure as a basis for determining the best means of providing for the enforcement of a proposed statute and the extent to which provision for its enforcement should be written into the statute rather than left to the discretion of administrative officials. In order that its research work might be kept close to practical problems, the officers of the fund have been glad of opportunities to render technical assistance in the preparation of legislative bills for legislators, other public agencies, or private organizations seeking reforms through legislation.

The determination of the wisdom of the policies underlying proposed legislation and propaganda for its enactment are left entirely to its proponents. The particular work of the fund consists solely in trying to translate propositions of legislation into effective statutes. This is not so narrow a field as one might assume. The drafting of legislation involves much more than matters of form, such as style, arrangement and choice of words. It involves appreciation of the conditions which it is desired to regulate, the means by which the purpose of the regulation can be best accomplished, the administrative organization, powers, duties and procedures which are best suited to the effective enforcement of the proposed regulation; and the adjustment of the proposed legislative and administrative scheme to existing constitutions; statutes and administrative organizations. In:

${ }^{1}$ Wherr the five years expired, the donation was extended for another period of five years. In the summer of 1917 a chair of legislatiom was created and the income of the fund was raduced by the amount of the endowment of the chair. 


\section{BILL-DRAFTING SERVICES}

addition to the legal research which this work naturally suggests, there is also involved the hardly less important research in administration to discover processes and devices likely to result in economical and efficient enforcement of proposed statutory provisions, and the investigation of economic and social conditions to discover the essential characteristics and scope of the evil requiring legislative remedy, and the precise nature and extent of the remedy needed.

A few examples will indicate the general nature of the work being done and the way in which its results have been utilized by public officials and semi-public organizations.

A complete revision of the substantive and enforcement provisions of the New York labor laws was prepared at the request of a legislative investigating commission. This revision was published with annotations explaining in minute detail proposed changes and the reasons therefor.

An index digest of the provisions of all the state constitutions as in force January I, I9I 5, was prepared at the request of the commission to prepare for the recent constitutional convention. The work was done under great pressure in order to have it ready for the use of the convention. A limited number of copies were printed by the state, which, after the needs of the delegates had been supplied, were distributed to libraries and educational institutions. It is copyrighted in the name of Columbia University.

In coöperation with committees of the American Bar Association members of the staff have prepared (I) a review of all general legislation enacted by Congress and the several state legislatures at the I9I5 sessions, and (2) memoranda for the guidance of draftsmen of legislation which will ultimately form part of a proposed manual of instructions to draftsmen and model clauses for the solution of constantly recurring legislative problems. They have coöperated similarly with the committees of the conference of commissioners on uniform state laws with the result that these bodies have had the advantage of more detailed legal work than they could otherwise have secured, and the fund's staff has had the benefit of the experience involved in this work.

Among the bills dealing with particular problems which the 
fund has been called upon to draft or revise are (I) bills to carry out the recommendations of the Senate committee which investigated the Titanic disaster, (2) the workmen's compensation bill recommended to Congress by the Sutherland Commission, President Taft's executive order putting into force a workman's compensation system for government employees on the Isthmus of Panama, and the existing New York constitutional amendment authorizing workmen's compensation laws, (3) the bill reorganizing the New York State tax department adopted this year, (4) the bill creating a New York industrial commission and merging in it the administration of the labor laws and the workmen's compensation laws.

In numerous instances it has rendered technical assistance on legal and administrative problems involved in the program of various semi-public organizations engaged in reform work requiring remedial legislation. In this work the effort is not to secure the desired reform, but to see that the legislation providing for it accomplishes its purpose effectively without necessarily disturbing related principles of law or administrative organizations. Drafting work has not been limited either to New York legislation or to Congressional legislation. Not only have bills been drafted for other states, but the fund is constantly coöperating with public drafting agencies throughout the country in an effort to increase the effectiveness of their work for the improvement of the statute law. A plan is now being considered under which the material and experience of the fund may be put at the service of members or committees of the Congress of the United States.

In conducting their research work, as well as in dealing with practical problems, the members of the staff have not only gained valuable experience, but have also gathered a store of material dealing with problems of political science which should in future be useful to the university. Much is being said and written about university training for the public service. The first requisite of more practical training in political science, so far as a university can give such training, is accurate and detailed data on the organization, powers and procedure of public agencies entrusted with the administration of public functions, whether federal, state or municipal. 


\section{BILL-DRAFTING SERVICES}

Materials of this sort are being gradually accumulated and indexed in the expectation that the work of the fund will substantially contribute to the effectiveness of instruction in the subjects with which its activities are concerned.

\section{PUBLICATIONS}

Index digest of state constitutions, prepared for the New York state constitutional convention commission, by the Legislative drafting research fund of Columbia university. [Albany?] New York state constitutional convention commission, I9I5. vii, I546 p.

Wyoming. In Wyoming, a Bill Drafting Committee was created as the result of an appropriation act approved February 24 , I9I $7,{ }^{1}$ which contained the item entitled "Compensation, Bill Drafting Committee," and made appropriation "for services rendered to members of both branches of the Legislature, and its committees, during the session, in the preparation of bills, resolutions and amendments thereto, examining and revising proposed bills, advising as to the effect thereof on existing laws and pending measures." The amount of the appropriation indicates that the members of the Bill Drafting Committee are expected to devote but a small part of their time to this service.

Other States. It will be seen from the foregoing that but few states have made provision for separate services to perform the functions of assisting members of the legislature in drafting bills. A very considerable number, however, have, as has been pointed out, entrusted this duty to their legislative reference department. In a number of states, moreover, such as Oregon and Washington, the office of the attorney general renders assistance of this kind. New Jersey, by an act passed in I9I4, provided for the appointment of an assistant attorney general to act as a legislative advisor and bill examiner, but this act was repealed in I9I 7 .

${ }^{1}$ Wyoming, Acts, I9I7, Sec. 55, Ch. I25, p. 232. 


\section{INDEX}

Accident insurance, $35 \mathrm{I}$.

Accounting (county), Alameda Co., Cal., 277; Westchester Co., N. Y., 275; improved system of for Cuyahoga County, O., 168.

Accounting (municipal), I89; Akron, I68, 250, 252; Baltimore, I7I ; Chicago, 204 ; Cincinnati, 22I ; Columbus, I68; Dayton, 234; Milwaukee, 239; Minneapolis, 244; New York City, I80; Philadelphia, 216; Rochester, 262; Springfield, Mass., 249, 312; Toledo, I68, 267; Toronto, 256; Yonkers, 268; improved system of, for Cleveland Associated Charities, I68; for Cleveland Federation for Charity and Philanthropy, I68; borough president's office, New York City, 208; police courts, New York City, 209; office of coroner, New York City, 209; bureau of school supplies, New York City, 2 I0.

Accounting (state), California, 288; Illinois, I37, I40, I43; Kansas, I50; New York, I87; in appeal tax court and collector's office, Maryland, I7I.

Accounting department, Denver, 258, 260; New Jersey, I I6, I I9; Ohio, I68, I70; U. S. Treasury, $92,96$.

Accounting (U. S. Government), history, 96 ; purpose, I02; $\mathrm{Bu}-$ reau of Indian Affairs, I07I08, II2; Post Office Department, 69, 7I ; Treasury, 69, 7I, 72 ; by disbursing and collecting officers of U. S., $76,82$.

Accounts, analysis of, 100; sug- gestions for developing uniform system of controlling, IO0; disbursing officers, methods of examining and auditing, I IO.

Adjutant General's Office, business methods of, 98 .

Administrative control, organs of, in states, 283-300; in cities, 30I-308.

Agricultural agencies, Illinois, I36, I42, I43; Kansas, I50; other states and countries, I43.

Agricultural settlement, Wisconsin, 290.

Agriculture, Department of, Alabama, I52; Connecticut, 150 ; Iowa, 148.

Akron Bureau of Municipal Research, I87; history and work, 250-253; publications, 254.

Alabama Department of Archives and History, history and work, 327; publications, 328.

Alabama Legislative Investigating Committee, history and work, I5I ; publications, I52.

Alameda County, Cal., Tax Association, history and work, 276; publications, 277.

Aldermen, Board of, New York City, 209.

Aliens, restriction on, in wartime, 356 .

Appointments, in Consular Service, 95 ; influence of politics in Boston, I98.

Appropriations, California, 287; Hudson County, N. J., 278; New York State, in legislative session of 1916, 187; accounting forms needed for, 100. 


\section{INDEX}

Appropriations and state revenue, Massachusetts, 123.

Archives and history department, Alabama, I52.

Arizona State Law and Legislative Reference Library, history and work, 328; publications, 329.

Armory Commission finances, Massachusetts, 123 .

Armory loans, Massachusetts, I23.

Arrests, record of, Baltimore, I7I.

Ash problem, Milwaukee, 206.

Asphalt pavement, Chicago, 228 ; Milwaukee, 240; Rochester, N. Y., 26I, 262.

Assessments, Toronto, 257.

Assessors, Board of, New Jersey, consolidation of, with Board of Equalization, II6, II8.

Attorney General's Office, Alabama, 152.

Auditing board, Colorado, I54.

Auditor, independent, New York State, I32.

Auditorium, Oakland, California, 277.

Auditor's office, Alameda County, Cal., 276, 277; Colorado, I54.

Australia, civil service retirement in, ro6.

Automobile laws, New England states, New York, New Jersey and Pennsylvania, 346.

Bacteriology bureau, Dayton, 234. Bail bonds, collection of money on, Boston, I99.

Ballot law commission, Massachusetts, I23.

Ballot system, simplification of, Boston, 193.

Bank commissioner, office of, Colorado, I54.

Bank deposits, guarantee of, Indiana, 332; Nebraska, 338.

Bank examiners, 349 .

Banking laws, of commercial states, 346 .

Bath department, Boston, I99.
Billboards, regulation of, Philadelphia, 219.

Bill drafting, hints on, Indiana, 332.

Bill drafting services, $365-37 \mathrm{I}$.

Blacklisting, $35 \mathrm{I}$.

Board of claims, New York State, 127.

Board of Consulting Experts, appointed to aid in investigating government business methods, 86.

Board of examiners, Connecticut, I 50.

Board of Referees, appointed, to aid in investigating government business methods, 86 .

Bonds, government officials', 69 , $72,79,82$.

Bookkeeping, U. S. Treasury, 80, 82.

Boston Finance Commission of I907-1909, history and work, I9I-193; publications, I97-199.

Boston Permanent Finance Commission, history and work, I94196; publications, 197-199.

Boycotting, 35I.

Bribery and corruption, Michigan, 335 .

Brick pavements, Rochester, N. Y., 262.

Bridges, Boston, I98.

Bridges and Harbors, Department of, Chicago, 201.

Briefing, 96.

Brown, Herbert D., 80.

Bruere, Henry, Administrative Reorganization in the Government of the City of New York, 210 ; Reorganization of the Office of the Chamberlain, 210; survey of departments under direction of (New York City), 2 IO.

Budget, in Canadian provinces, I88.

Budget (county), Cook County, I11., 228; Westchester County, N. Y., 274, 276.

Budget (municipal), Akron, O., 25I, 254; Baltimore, I7I ; Boston, I97, 199; Chicago, 201, 


\section{INDEX}

204; Cincinnati, 22I, 222; Columbus, O., I68; Dayton, 23I, 235, 236; Denver, 258, 260 ; Detroit, 266; Memphis, 270; Milwaukee, 239; New York City, 183, I88, 302; Philadelphia, 216, 219; San Francisco, 265; Springfield, Mass., 248, 249, 250; Toledo, O., I68; Toronto, 256, 257; Yonkers, 268, 269; effect of mandatory legislation upon, New York City, 209.

Budget (national) inquiry into need for, 87-91; need for (1912), 97, 99.

Budget (state), I88; Alabama, I 52; California, 287; Colorado, I 54; Illinois, I42, 33I ; Indiana, 333; Iowa, I48; Kansas, I 50 ; Louisiana, I57; Maryland, I66, I87; Massachusetts, 125, 296; Minnesota, I45, I46; Nebraska, 338; New Jersey, I64, I65, I86; New York, I29, I3I, I78, I88; North Dakota, 34I ; Oregon, I60; Pennsylvania, I34; Virginia, I56; Wisconsin, 290; constructive proposals to be submitted to the state constitutional convention, New York, I 85.

Budget idea in the United States, The, I86.

Budget procedure, development of, for Greater New York, I 85 ; practical side of, 185 .

Budget systems, a discussion before the New York Constitutional Convention, 185 .

Budget, The, by René Stourm, 43.

Building and loan association, department of, Colorado, I 54 .

Building code, Dayton, 233.

Building Commission, Westchester County, N. Y., 275, 276.

Building department, Boston, I99; Chicago, 200.

Building Inspection, Baltimore, I7I ; Minneapolis, 246.

Buildings, Chicago, 203; Detroit, 266; Illinois, I37, I42, I43.
Business agent's office, Chicago, 200.

Business methods, Bureau of Internal Revenue, Io9; Bureau of Pensions, I09; Civil Service Commission, Iro; U. S. Departments, 107.

California Legislative Counsel Bureau, history and work, 329; publications, 330 .

California Legislative Reference Department, history and work, 357 ; publications, 357.

California State Board of Control, history and work, 284286; publications, 287.

California Taxpayers' Association, work of, 166.

Campaign expenditures, limitations on, 356 .

Canada, provincial budget system of, I 88.

Canadian Budgetary System, The, By Harold G. Villard and W. W. Willoughby, 43.

Canal claims, New York State, 127.

Canal Commission, New Jersey, consolidation of, with department of inland waterways, I I7, II9.

Canals, Ohio, 342.

Castings, purchase of, Chicago 200.

Census, Bureau of, catalogue and price list of supplies used in, Ioo.

Central administrative control, need for organization of, 99 .

Central power and heating plant, Boston, I98.

Central stores system, Kansas, I5o.

Certified public accountants, $35^{2}$. Chamberlain, office of, New York City, 2 Io.

Chance, Merrit O., member, President's Commission on Economy and Efficiency, 86.

Charitable activities, inquiry regarding, New York City, I82. 


\section{INDEX}

Charities and corrections, Board of, Colorado, 154.

Charities, Board of, Connecticut, I50.

Charities Department, Philadelphia, 217, 219; Rochester, N. Y., 26I, 263; Springfield, 250.

Charities, public, Pennsylvania, 344.

Charter (county), Alameda County, Calif., 276, 277.

Charter (municipal), 349, Akron, 254, 255; Cincinnati, I69, 222; Columbus, O., 270; Dayton, 231, 237, 238; Denver, 258; Philadelphia, 219; Springfield, Mass., 249, 250.

Charters, municipal home rule, $35 \mathrm{I}$.

Chase, Harvey S., member, President's Commission on Economy and Efficiency, 86.

Check-paying system, for employees, Boston, 199.

Checks and vouchers, assembling of, 79,82 .

Chemistry bureau, Dayton, 234

Chicago Bureau of Efficiency, 187.

Chicago Bureau of Public Efficiency, history and work, 223227; publications, 228-229.

Chicago Commission on City Expenditures, history and work, 200 ; publications, 200.

Chicago Efficiency Division of the Civil Service Commission, history and work, 20I-202; publications, 203.

Chief medical examiner, office of, (New York City), 2Io.

Chief of Engineers, office of, mail and record division, 98 .

Chief of Ordnance, office of, handling correspondence in, 98.

Child hygiene, New York City, I82, 188; Philadelphia, 217.

Cincinnati Bureau of Municipal Research, history and work, 220-22I ; publications, 222.

Cipher coding systems, instruc- tions for preparing report on, IOI.

Citizen agencies for research in government, 187.

Citizen and the government, The, 185 .

City clerk's office, Chicago, 201 ; New York City, 209.

City council, election of, Boston, 193; participation of members of, in executive and administrative business, Boston, 199.

City debt, Boston, 197, 198 .

City government, unofficial agencies for investigating, 212$27 \mathrm{I}$.

City government, Atlanta, 182; Boston, 197; Chicago, 203; Cincinnati, 221, 222; Columbus, O., I84; Dayton, 232, 236; plan for establishing model in District of Columbia, I89; Indiana, 333; Indianapolis, 185 ; Jamestown, N. Y., I84; Los Angeles, I82; Memphis, 270; New York, 189, 209, 210; Portland, Ore., I83; Reading, Pa., I84; Richmond, I85; Rochester, N. Y., I83, 26r, 262; St. Louis, I82; San Francisco, 184, 263; Springfield, Mass., 182; Toledo, 267.

City manager plan, Chicago, 229; Dayton, 237; Petersburg, Va., 271.

Civics, instruction in, in New York City high schools, I88.

Civil engineering service, standardization of salaries in, Massachusetts, 125 .

Civil list, Dayton, 235 .

Civil servants, legal rights of, New York City, 186.

Civil service, Akron, O., 25I ; Virginia, 157.

Civil Service Commission, 104106; Chicago, 201; Denver, 258; Milwaukee, 239; Minneapolis, 243; business methods of, IIo.

Civil service commissions, in the United States, list of, I88.

Civil service laws, Illinois, 143; 


\section{INDEX}

Ohio, 342; in United States and other states, 143.

Claims, audit of, Westchester County, N. Y., 274, 275; Yonkers, 269; California, 287; United States, I Io.

Classification of Employments. See Salary Standardization and Public Employments, Standardization of.

Clearing house, Ohio, I69.

Clerical force, executive departments, proposed reclassification of (1907), 83 .

Clerk of Circuit Court's Office, Cook County, I1l., 228, 229.

Clerk of Council's Office, Akron, 253.

Clerk of County Court's Office, Cook County, Ill., 229.

Clerk of Superior Court's Office, Cook County, Ill., 228, 229.

Cleveland, Ohio, Associated Charities, organization and methods of, 168.

Cleveland, Ohio, Federation for Charity and Philanthropy, organization and methods of, 168.

Cleveland, Frederick A., Chairman, Commission on Economy and Efficiency, 85.

Clothing, for city employees, purchase of, Boston, 199 .

Coal, purchase of, Boston, I98, Chicago, 20I ; by institutions, Maryland, $\mathbf{I}$ I.

Coal specifications, Chicago, 227.

Cockrell Committee, history and work of, 57-63; publications of, 63-65.

Code commissioner, Alabama, I 52 .

Colorado Survey Committee of State Affairs, history and work of, 152 ; publications of, I54.

Columbia University Legislative Drafting Bureau, history and work, 367-370; publications, 371.

Columbus Bureau of Municipal Research, history and work of, 270.
Combustibles, department of, New York City, 2 Io.

Commerce and Labor, Department of, see Bureau of Lighthouses.

Commerce and Navigation, Department of, New Jersey, II7, IIg.

Commercial lighting, Cincinnati, 220.

Commission merchant inspectors, Colorado, 154.

Committees in department work, use of, 77,82 .

Compensation and employment, laws regulating United States, (I893), $7 \mathrm{I}$.

Complaint system, Minneapolis, 245.

Comptroller's office, Milwaukee, 239.

Comptroller of the Treasury, New Jersey, consolidation of office with department of accounts, II6, II9.

Compulsory attendance bureau, Cincinnati, 222, 223.

Compulsory education bureau, Philadelphia, 2I5.

Concession privileges, Boston, I99.

Congress, inquiries by, regarding national administration, 4556.

Connecticut Bill Drafting Service, history and work of, 365 .

Connecticut Legislative Reference Department, history and work, 357; publications, 358 .

Connecticut State Commission on the Consolidation of State Commissions and the Reorganization of the Public Health Laws, history and work, I49; publications, I49.

Conservation and Development, Department of, New Jersey, I I 7, I I9.

Constitutional conventions, Ohio, 342.

Consular Service, regulations governing appointments and promotions in (1912), 95 . 


\section{INDEX}

Contagious diseases of domestic animals, laws relating to, Massachusetts, 125 .

Contracts, Illinois, I43; for local improvements, Rochester, N. Y., 26I ; U. S. government, $80,82$.

Convict department, Alabama, 152.

Coöperation, store, Wisconsin, 290.

Coroner's office, Cook County, Ill., 228; New York City, 210.

Corporation audits, New Jersey, 164.

Corporations, Michigan, 336; Pennsylvania, 344 ; state supervision of, Colorado, I54, Illinois, I43.

Correspondence, filing of, in U. S. departments, $70,73,94,96$; U. S. Departments, subjective classification of, 96 ; registers of, 96; elimination of salutation and complimentary close in, 96; handling of, in mail and record division, Office of Chief of Engineers, 98; in Bureau of Insular Affairs, 98, in office of Surgeon General, 98, in office of Signal Corps, 98 , in office of Chief of Ordnance, 98 , in Department of Justice, 98, in executive departments, IOI ; instructions to be followed in handling, Ioo.

Corrupt practices, 35 I.

Cost data, collection of, Ioo.

Costkeeping, in U. S. government, 78, 82; Milwaukee, 239.

Cost of living, New York City, 306.

County bond issues, Chicago, 229.

County fee offices, Cook County, Ill., 225, 229.

County government, unofficial agencies to investigate, 272278; Alameda County, Calif., 277; Monroe County, N. Y., I83, 261, 262; Nassau County, N. Y., 183 .
Customs, method of collecting, ( 1895$), 70,73$.

Cutting, R. Fulton, Public Opinion and National Economy, I86.

Dairy products, production and standards of, California, 330.

Day laborers, efficiency of, Boston, 198.

Dayton Bureau of Research, I87; history and work of, 230235; publications of, 236-237.

Debt, Denver, 258; New York City, I8o, I8I.

Denver Civic and Legislative Bureau of the Denver Civic and Commercial Association, history and work of, 258-259; publications of, 260.

Dependents, delinquents and defectives, care of, Colorado, I 53,154 .

Deposits of postmasters, disposition of, 69, $7 \mathrm{I}$.

Detention home, Alameda County, Calif., 277.

Detroit Bureau of Governmental Research, history and work of, 265; publications of, 266.

Dictation machine, 96; in Post Office Department, 96.

Direct primary, Nebraska, 338.

Districting, for work of charitable institutions, Baltimore, I 72.

Dockery-Cockrell Commission, history and work, 66-7I; publication, 7I-73.

Documents, schedules and registers of, IOo; U. S. Government, distribution of, 94; photographic processes for copying, 94,95 .

Duplication of service, in U. S. government, II 2 .

Education, Department of, Alabama, 152, Atlanta, 182, Minneapolis, 245.

Educational agencies, administration of, Illinois, 142, I43; other states and countries, I43. 


\section{INDEX}

Educational code, Denver, 259, 260.

Efficiency, Bureau of, history and work, I06-II2; publications, II $2-113$.

Efficiency, Division of, II6-II7; see also Bureau of Efficiency.

Efficiency ratings, U. S. Government, 104-108; in National Bank Redemption Agency (I913), 99, 102.

Efficient Citizenship, 185.

Election Commission, Denver, 258.

Election days as holidays, Chicago, 230.

Elections, Alameda County, Calif., 277; Chicago, 229; New York City, 209; Michigan, 335.

Electricity, department of, Chicago, 20I, 203.

Electric lighting, federal buildings, 99 ; municipal, $35 \mathrm{I}$.

Electric light plant, expenditures of, Columbus, O., I69.

Employees, efficiency of, Wisconsin, 29I.

Employer's liability, Rhode Island, 346 .

Employers' Liability Commission, New Jersey, consolidation of, with other agencies, II6, II8.

Employment bureaus, Milwaukee, 205.

Engineer, in Public Service, The, I 87.

Engineering department, Rochester, N. Y., 262.

Engineer service, Chicago, 203.

Enrollment of bills, (1893), 68, 71 .

Enumeration districts, Baltimore, I72.

Equalization, Board of, New Jersey, consolidation of, with Board of Assessors, II6, II7, I 18 .

Estimates, California, 287; Maryland, $17 \mathrm{I}$; preparation of analyses of, ror.

Examining Board, Illinois, 143.
Excess condemnation, Chicago, 230,

Executive, relations to legislature, New York State, I32.

Executive organization, proposed in Illinois, 144.

Exemptions from taxation, Michigan, 336.

Expenditure accounting and reporting, 102, 103.

Expenditure documents, catalogues used in preparation of, IOI ; forms of, 103 .

Expenditures, San Francisco, 263, 265; Toledo, 267; U. S. government, classification of, 99-IOI ; standardized classification of, for use by state departments, cities, etc., Ohio, I69.

Expense accounts, Springfield, Mass., 250; Massachusetts, I23; Virginia, 156.

Expense classification, Cincinnati, 22I ; Minneapolis, 243.

Farm ownership, Wisconsin, 290.

Federal buildings, electric lighting of (1913), 99.

Federal Government as an Example, The, by William $\mathrm{H}$. Taft, 186.

Federation for charity and philanthropy, Dayton, 235 .

Fees, retention of, Minneapolis, 244; abolition of, Virginia, I56.

Fee system, 349 .

Ferry department, Boston, 199.

Filing, vertical flat, 96 .

Finance Commission, Boston, organization and work of, 187.

Finance Department, Denver, 258.

Finances, Akron, 250, 255; Chicago, 230; California, 288; Ohio cities, 342 .

Financial Administration with Special reference to English Experience, by A. Lawrence Lowell, 186. 


\section{INDEX}

Financial administration, Boston, I9I-I92; Columbus, I69; Detroit, 266; Michigan, 336; New York City, I80; Toledo, I69; Illinois, I36, I42; New York State, I86; Great Britain, 43; Japan, I88; central control of, in New York City, 188.

Fire and police alarm telegraph system, Milwaukee, 205.

Fire apparatus, automobile, Boston, 199; motorization of, Dayton, 233.

Fire department, Chicago, 20I; Dayton, 233; Milwaukee, 240, 24I ; Philadelphia, 218; Toronto, 256 ; purchase of equipment, Yonkers, 269.

Fire hose specifications, Rochester, N. Y., 26r, 262.

Fire insurance, Illinois, I44; on city property, Philadelphia, 219.

Firemen, granting time off to, Boston, 199.

Fire protection, Boston, 198.

Fiscal year, Virginia, I 56 .

Fish and Game Conservation Commission, Illinois, I43.

Fisheries and Game, Board of, Connecticut, 150.

Fisheries and Game Commissioners, Massachusetts, I23, 125.

Flood protection, Indiana, 333 .

Floor preservatives, Boston, I99.

Foodstuffs, control over handling of, Philadelphia, 217, 220.

Forest protection, Michigan, 336.

Forestry, Massachusetts, I23.

Full crew law, New Jersey, I64, 165.

Game and fish, protection of, Colorado, I53, I54.

Game and fish commissioner, Alabama, 152.

Garage service, Boston, I99; Cincinnati, 22I.

Garbage collection, Akron, $\mathrm{O}$, 251, 253; Dayton, 289; Mil- waukee, 206; Rochester, N. Y., 26I ; Toledo, 267.

Garbage disposal, Dayton, 232; Rochester, N. Y., 26r ; Toronto, 256; see also Refuse disposal.

Garnishment of wages, Milwaukee, 205.

Gas and electric systems, valuation of, Cincinnati, 223.

Gas lighting, municipal, 35r.

General Land Office, consolidation of, 70 .

General Supply Committee, creation of, 77 .

Geological Survey, The, 43.

Georgia Legislative Reference Department, history and work, 358 ; publications, 359 .

Goodnow, Frank J., member, President's Commission on Economy and Efficiency, 86; Administration and Financial Methods, I86; State Government from the point of view of Administrative Law, 186.

Government crop reports (1906), $75,8 \mathrm{I}$.

Governor, office of, Colorado, I 53, I 54 .

Grade crossings, Dayton, 236; Detroit, 266.

Great Britain, financial administration of, 43; civil service retirement in, 97 .

Hall of Records power plant, New York City, cost of operation and maintenance, I84.

Health department, Atlanta, I82; Boston, 197, 199; Chicago, 204; Dayton, 234, 236; Milwaukee, 206; Minneapolis, 244; New York City, 180; Philadelphia, 217, 219; St. Paul, 182, I89; Springfield, Mass., 249; Toronto, 257; New Jersey, II7, II9.

High schools, Boston, I99; Wisconsin, 291.

Highway administration, problems of, 188. 


\section{INDEX}

Ohio, 342 ; of the United States, 188 .

Highways, North Dakota, 34I ; administration of, Illinois, I43; construction and maintenance of, New York State, I3O, 132 .

Highway system, New Jersey, I65, I66.

Hospital, emergency, Alameda County, Calif., 277.

Hospital for contagious diseases, Philadelphia, 217.

Hospital, general, Minneapolis, 245; Philadelphia, 217.

Hospitals for consumptives, Boston, I98.

Hospitals, inquiry regarding, New York City, I 82.

Hospitals for insane, New York State, I30, I3I ; Springfield, Md., I II.

Hours of labor, in U. S. Government (I906), 78, 82; of public employees, Massachusetts, 125 .

House of Correction, Chicago, 204.

House of Refuge, Cincinnati, 223.

Housing and health, Ohio, I70; Philadelphia, 217.

Hudson County (N. J.) Citizens' Federation, history and work, 278; publications, 278 .

Illinois Department of Finance, history and work of, 296-297.

Illinois Efficiency and Economy Committee, history and work, I34-I4I ; publications, I42-I43.

Illinois Legislative Reference Bureau, history and work, 330 ; publications, 33I.

Immigration Department, Alabama, 152.

Improvements Department, Denver, 258.

Indebtedness of American cities, purposes of, 187 .

Indiana Legislative and Statistical Bureau, history and work, 332; publications; 332 .
Indianapolis Bureau of Governmental Research of the Indianapolis Chamber of Commerce, history and work of, 269.

Indian Office, bookkeeping system for, 107-108; administration of, I83, I86.

Indian Service, proposed business procedure of (I9II), IOO.

Industries, Alabama, I52 ; Connecticut, I50 ; Iowa, I48.

Infirmary, Alameda County, Calif., 277.

Inheritance taxation, Indiana, 332.

Initiative, 342, 35I, 352 .

Inland Waterways, Department of, New Jersey, consolidation of, with Canal Commission, II 7 , II9.

Insane, care and treatment of, Colorado, I 54 .

Inspector of oils, office of, Colorado, I 54.

Institute for Government Research, $3^{\mathrm{I}-43}$.

Institutions, children's, Boston, I98; charitable, Denver, 259, 260, Illinois, I42, I43, Kansas, I50, I5I, New York State, I3I ; correctional, Boston, I98, Chicago, 20I, Illinois, I42, I43, Kansas, I50, I5I, New York State, I3I ; county, business administration of, Massachusetts, I23; educational, Kansas, I50, I5I ; state, alien immigrants admitted to, Massachusetts, I23; non-registered physicians employed at, Massachusetts, I24; reorganization of commissions having control of, Massachusetts, I22, I23, I24, bills and appropriations connected with, New York State, 127, control and supervision of, Indiana, 333, organization of state control, Oregon, I60; state-aided, Massachusetts, I24.

Institutions for minors, Colorado, I 54 . 


\section{INDEX}

Insular Affairs, Bureau of, correspondence and statistical work in (I9I3), 98.

Insurance department, Colorado, I 54 .

Internal Revenue, Bureau of, business methods of, Iog.

International money orders, statistics of (I894), 70, 72 .

Iowa Joint Committee on Retrenchment and Reform, history and work, I47; publications, I48.

Iowa Law and Legislative Reference Department, history and work, 359; publications, 359.

Janitor service, Chicago, 203.

Japan, administration and finance in, 188.

Job selling in industrial establishments, Ohio, I70.

Judiciary department, Virginia, I56.

Jury commissioner's office, Denver, 258.

Justice, Department of, handling correspondence in, 98 .

Juvenile courts, 349, 35I ; Cincinnati, 223; Denver, 258.

Juvenile court laws, Pennsylvania, 344 .

Kansas Efficiency and Economy Committee, history and work, I50; publications, I5I.

Kansas Legislative Reference Department, history and work, 333; publications, 333 .

Keep Committee, history and work, 74-8I ; publications, 8I83 .

1

Labor regulation, Colorado, 154.

Labor, Department of, New Jersey, consolidation of, with other agencies, II6, II7, II8.

Labor agencies, administration of, Illinois, I36, I43; Ohio, I 70 .

Labor and Factory Inspection Department, Connecticut, I 49.
Laborers, vacations for, Boston, 199.

Labor-saving devices, suggestions for use of, 94,96 ; in executive departments U. S. government, Ior ; in payment of pensions, 108-109.

Labor Statistics, Bureau of, New Jersey, consolidation of, with other agencies, II6, II7, II8.

Lake tunnel system, Chicago, 200.

Land, taxation of unearned increment of, Boston, I98.

Land cases, contested, 70, 72.

Land court, Boston, I98.

Land offices, registers and receivers of, 70,72 .

Land patents, engrossing and recording (1895), 70, 72.

Lawmaking, procedure in, Illinois, 33I.

Laws, codification of, Alabama, I52.

Leaves of absence, in U. S. Government, 78, 82; Virginia, I56.

Legal advertising, laws relative to, Ohio, 342.

Legal aid, Milwaukee, 205.

Legal aid bureau, Dayton, 234.

Legislative index, New Jersey, I63.

Legislative reference and billdrafting service, report of committee of American Bar Association, 313-326; agencies furnishing, $327-352$.

Legislative reference services, 353-364.

Legislature, relation to executive, New York State, I32; organization of, New York, I32, Virginia, 156; procedure of, New York, 132 .

iLibrary activities, state sup-

ported, 338.

Library of Congress, Legislative Reference Division, history and work, 353-355; publications, 356 .

Licenses, Dayton, 232; Philadelphia, 219; for private uses of 


\section{INDEX}

public streets, Boston, 198 ; for minors, Boston, 198; for stands for sight-seeing automobiles, Boston, 199.

Life Saving Service, recommendation for consolidation with Bureau of Lighthouses, 92, 95; history, organization and activities of, 96 .

Life saving stations, location of (1912), 96.

Lighthouses, Bureau of, recommendation for consolidation of with Life Saving Service, 92, 95 ; history, organization and activities of, 96 .

Liquor laws, Pennsylvania, 344.

Liquor question, 349.

Liquor traffic, Michigan, 336.

Lobbying, 35I.

Local governments, unification of, Chicago, 227, 229.

Los Angeles Bureau of Efficiency, 210.

Louisiana Board of State Affairs, history and work, I57; publications, 158.

Lowell, A. Lawrence, Financial Administration with Special Reference to English Experience, 186.

Lumber, purchase of, Chicago, 201.

Mailing machinery, 96 .

Maine Legislative Reference Bureau, history and work of, 359.

Mandamus, use of, Philadelphia, 219.

Marine Hospital Service, regulations governing (I9I2), 95 .

Markets, Dayton, 232 ; Wisconsin, 290.

Maryland Bureau of State and Municipal Research, history and work, I7I; publications, I7I.

Maryland Commission on Economy and Efficiency, history and work, 166; publications, I66.

Maryland Department of Legis- lative Reference, history and work, 333; publications, 334 .

Massachusetts Bill Drafting Service, history and work of, 366.

Massachusetts Commission for the Blind, selling methods used by, I23.

Massachusetts Commission on Economy and Efficiency, history and work, II9-I2I; publications, I22-I25.

Massachusetts Legislative Reference Department, history and work of, 360 .

Massachusetts Supervisor of Administration, history and work of, 29I-295; publications of, 296.

Mayor, concentration of executive power and responsibility in, Boston, 193.

Medical school, Minneapolis, $243,245$.

Memphis Bureau of Municipal Research, history and work, 270; publications, 270.

Merchant marine, foreign legislation on, 356 .

Merit system, Minnesota, I44.

Metz Fund, publications of, I89.

Michigan Legislative Reference Department, history and work, 334; publications, 335 .

Military affairs, Michigan, 336 .

Military Department, Alabama, I52; Illinois, I43.

Military functions, organization for, New York State, I32.

Military service, exemption, Great Britain, 356 .

Milk inspection, Philadelphia, 217.

Milwaukee Bureau of Economy and Efficiency and Bureau of Municipal Research, history and work, 204; publications, 205.

Milwaukee Citizens Bureau of Municipal Efficiency, I87; history and work of, 238-240; publications of, 24I. 
Minimum wage law, Wisconsin, 205.

Mining legislation, Illinois, 136, I43.

Minneapolis Bureau of Municipal Research, 187.

Minneapolis Bureau of Municipal Research of the Minneapolis Civic and Commerce Association, history and work, 242-245; publications, 246.

Minnesota Commission on Reorganization of Civil Administration, history and work, 146; publications, I 47.

Minnesota Efficiency and Economy Commission, history and work, I44; publications, 145 .

Mississippi Joint Investigating Committee, work of, I6I.

Missouri Legislative Reference Department, history and work, 336; publications, 337 .

Money orders, destruction of old, 69,72 ; checking of, 70 , 73 .

Montana Legislative Reference Bureau, history and work, 337.

Mortgage taxation, 35I.

Moth suppression, Massachusetts, I23.

Motor vehicles, laws, 336 .

Movement for Budgetary Reform in the States, The, by William $F$. Willoughby, 43 .

Municipal administration, unofficial agencies for studying, I73-190.

Municipal Court, Cincinnati, 222, 223; Philadelphia, 218.

Municipal Court Act, Chicago, $226,228$.

Municipal government, see City government.

Municipal home rule, 349 .

Municipal reports, unit costs in, 189.

Municipal Research, 185.

National administration, official agencies for investigating, 44II3.

National Bank Redemption
Agency, efficiency records in, 99, 102.

Naval Officer, Customs Service, abolition of office of, 70 .

Navy Department, organization of, 99-100.

Nebraska Legislative Reference Bureau, history and work, 337; publications, 338 .

Negro education, Philadelphia, 215.

New England Cotton Manufacturers' Association, resolution of, regarding government crop reports, 75 .

New Hampshire Legislative Reference Bureau, history and work, 339.

New Jersey Bureau of State Research, history and work, I63I64; publications, I65.

New Jersey Economy and Efficiency Commission, history and work, II5-II8; publications, II 8-II9.

New Jersey Legislative Reference Department, history and work, 360 ; publications, 361 .

New Jersey State Chamber of Commerce, history and work, I62-164; publications, I65.

New Mexico Taxpayers Association, work of, 166 .

New South Wales, civil service retirement in (19I0), 97.

New York Board of Estimate and Apportionment, history and work, 30I-304; publications, 305 .

New York Bureau of Municipal Research, history and work, 173-179; publications, 180-190.

New York Department of Efficiency and Economy, history and work, I28-i3o; publications, I3I.

New York State Bill Drafting Commission, history and work of, 366 .

New York State Commissioner of Accounts, history and work, 206-207; publications, 208-209. New York (State) Committee 


\section{INDEX}

of Inquiry to Investigate the Administration of the State Government, history and work of, $126,127$.

New York State Legislative Library, history and work of, 363.

New York State Legislative Reference Section, history and work, $36 \mathrm{I}$; publications, 362 .

New Zealand, civil service retirement in (1910), 97.

North Carolina Legislative Reference Department, history and work, 339; publications, 340.

North Dakota Legislative Reference Bureau, history and work, 340; publications, 34I.

Normal schools, Massachusetts, 123; Wisconsin, 290.

Office hours, uniform, Virginia, I56.

Ohio Institute for Public Efficiency, 187 ; history and work of, I67-169; publications of, I 70.

Ohio Joint Investigating Committee, work of, I6r.

Ohio Legislative Reference Department, history and work, 34I ; publications, 342.

Oregon Consolidation Commission, history and work of, I59.

Oregon State Library, history and work of, 363 .

Organic law, Ohio, 342.

Organized Efforts for the Improvement of Methods of $A d$ ministration in the United States, by Gustavus A. Weber, 43.

Over-age, in schools, Cincinnati, 221, 223; Dayton, 236.

Overtime, payment for, Boston, I99.

Oyster industry, 349.

Paper money, recovery of fiber stock of cancelled, 99.

Park administration, New York City, I80.
Park board, Minneapolis, 245.

Park governments, consolidation of, Chicago, 226, 229.

Party nominations, abolition of, Boston, 193.

Patent Law and Procedure of Germany, England and United States, 98.

Patent Office, investigation of, 97; publications of, 98 .

Patrolman's manual, Philadelphia, 218, 220.

Paving, Dayton, 235; see also Asphalt pavements, Brick pavements.

"Pay-as-you-go" agreement, New York City, I85.

Payroll control, Milwaukee, 239.

Payrolls, preparation and payment of, roI.

Pennsylvania Economy and Efficiency Commission, history and work of, 133 ; publications of, I34.

Pennsylvania Legislative Reference Bureau, history and work of, 343; publications of, 344 .

Pension and retirement fund commission, New Jersey, I65.

Pension systems, police, New Jersey, 165; firemen's, New Jersey, 165.

Pensions, Bureat of, business methods of, Io9.

Pensions, establishment of improved system for payment of, 108-109; U. S. employees, estimates of immediate and ultimate cost of, 107.

Petersburg (Va.) Bureau of Governmental Research, history and work, 27I ; publications, 27I.

Philadelphia Bureau of Municipal Research, r87; history and work, 213-218; publications, 219.

Plumbing inspection, Milwaukee, 206.

Pneumatic tube system, underground, 99, I02.

Police department, Baltimore, I7I ; Chicago, 20I, 203; Day- 


\section{INDEX}

ton, 233; Minneapolis, 246; New York City, I80, I8I, I83; Philadelphia, 218.

Police pension fund, New York City, 183.

Police power, sanitary, Rhode Island, 346.

Police surgeons, New York City, 210.

Positions, appointment to, made by President with advice and consent of Senate, 99; creation of, Pennsylvania, I34.

Presidential primaries, laws relating to, 336 .

President's Commission on Economy and Efficiency, history and work of, 84-94; publications of, 94-I03.

Press copy versus carbon copy, 96; legal aspect of, 98 .

Primaries, 349.

Primary elections, 35I.

Principles Governing the Retirement of Public Employees, by Lewis Meriam, 43.

Principles of Government Purchasing, by Arthur G. Thomas, 43.

Printing, Westchester County, N. Y., 275, 276; Boston, I97; New York City, 2ro; Alabama, I52; Illinois, I43; Iowa, I48; Massachusetts, I25; New York State, I27; Wisconsin, 29I ; in other states, I43.

Prison Control, Department of, New Jersey, II7, II9.

Prisons, New York State, I3I, I79.

Problem of a National Budget, The, by William $\mathrm{F}$. Willoughby, 43 .

Procter, Arthur W., ed. Standardization of Public Employments, I86.

Promotions in consular service (I9I2), 95.

Property department, Denver, 258.

Property returns, California, 287; U. S. government, 69, 7I.

Proportional representation, 35I.
Protection of birds, 349 .

Public administrator, Denver, 258.

Publications, U. S. historical, 8I, 82 ; of U. S. government, centralization of distribution of, $95,96$.

Public buildings and grounds; Virginia, 156.

Public documents, Boston, 197, Massachusetts, 296.

Public employees, political activity of, Boston, 198.

Public employment, standardization of, 186, I87; Milwaukee, $24 \mathrm{I}$; See also Salary standardization.

Public examiner, office of, Colorado, 154.

Public funds, custody of, Colorado, 153 .

Public health, Connecticut, I50; inquiry regarding, New York City, I 82 ; administration of, Illinois, I36, I42, I43; relation between state and local authorities, Illinois, I43; administration of, New York and Wisconsin, I43.

Public Health Service, regulations governing, 95 ; establishment of as independent service, 99.

Public lands, Michigan, 336 .

Public Opinion and National Economy, by R. Fulton Cutting, I 86.

Public printing, cost of, $75,8 \mathrm{r}$.

Public property, returns from lessees of, Dayton, 236.

Public records, care of, Massachusetts, I23.

Public safety, Iowa, I48.

Public schools, see Schools.

Public service commission laws, 342.

Public surveys, improvement of, 70,73 .

Public utilities, control of, Colorado, I54; New York and Wisconsin, 342.

Public Welfare Department, Dayton, 235. 


\section{INDEX}

Public Works Department, Boston, I98; Philadelphia, 218; Rochester, N. Y., 26I ; Illinois, I42, I43.

Purchases, centralization of, Philadelphia, 218, New Jersey, II8, II9.

Purchases of coal and wood, for use by government, 69,72 .

Purchasing, Columbus, O., I69; Minneapolis, 244; Toledo, I69; Virginia, 156.

Purchasing agency, Alameda County, Calif., 277.

Purchasing agent, municipal, Baltimore, I7I; creation of office of, Iowa, I48.

Purchasing control, Massachusetts, 296.

Purchasing Department, Akron, 253; Alabama, I52; Dayton, 234; Milwaukee, 240, 24I ; Springfield, 249.

Railroad Commission, Alabama, I52.

Railway co-employment, 35 I.

Railways, government control of, in Great Britain, 357 .

Rates of pay, IIo.

Recall, 35I.

Receipts and disbursements, methods of accounting for, IIO.

Receipts and expenditures, Wisconsin, 29I.

Reclamation Service, The, 43.

Recorder's Office, Alameda County, Calif., 277; Cook County, Ill., 228.

Recreation department, Boston, I98; Dayton, 234.

Recreation facilities, Toronto, 257.

Recreation survey, Milwaukee, 206.

Referendum, 342, 35 I, 352 .

Reformatory, New York State, I3I.

Refuse disposal, Boston, 198; by incineration, Milwaukee, 205.

Registers and directories of U.S. Government, $\mathrm{r} 88$.
Registry Department, Boston, I98.

Removal from office, Michigan, 336.

Reports, uniform system of summary, IOO; of state departments, Illinois, I38.

Responsible Government, I86.

Retirement of superannuated government employees (I9I2), 96.

Retirement system, Boston, I98; firemen, Boston, 198, Dayton, 233; policemen, Dayton, 233, New York City, 2Io.

Returns Office, Interior Department, abolition recommended, $92,96$.

Revenue, sources of, Dayton, 232, Philadelnhia, 219; collection of, Yonkers, 269.

Revenue administration, Illinois, I43.

Revenue Cutter Service, abolition recommended, 92, 96 .

Revenues and disbursements, accounting, auditing and reporting of, Colorado, I 53, I 54.

Revenues and loans, Massachusetts, I25.

Rhode Island Legislative Reference Bureau, history and work, 345 ; publications, 346 .

Rochester Bureau of Municipal Research, history and work, 260-26I ; publications, 262.

Roosevelt, President, 74.

Rural schools, Ohio, 235 .

Safety Department, Denver, 258.

Salaries, executive departments, 83 ; arsenals and navy yards, 83 ; U. S. employees, II I Chicago, 204; Yonkers, 268, 269; Hudson County, N. J., 278; Illinois, I35; Massachusetts, I20, I23; Pennsylvania, I34.

Salary standardization, 187 ; Akron, 253; Boston, I99; Chicago, I87; Cincinnati, 22I ; Milwaukee, 206; New York City, I82, 187, 303, 306; Philadel- 


\section{INDEX}

phia, 217, 220; Pittsburgh, 187; Massachusetts, 125, 296; New York State, I78, I87; U. S. Government, 78,83 , IOI, II I ; see also Public Employment, standardization of.

San Francisco Bureau of Government Research, history and work, 263-264; publications, 265.

Sanitary department, Boston, I97.

School district, Reading, Pa., I84.

School of medical inspection, Philadelphia, 217.

Schools, Alameda County, Cal., 276, 277 ; Akron, 254, 258; Boston, I97, 198, 200 ; Cincinnati, 223 ; Columbus, I69; Dayton, 237; Denver, 258; Detroit, 266; Milwaukee, 240; New York City, I8I ; Philadelphia, 216, 219; Toronto, 257; Michigan, 335; Nebraska, 338; Virginia, I57 ; district supervision of, Boston, I99; expenditures for, compared with other American cities, Boston, 200 ; special departments in, Boston, I99; budget for, Chicago, 204; rural, Wisconsin, 189 .

Secretary of State, office of, Colorado, 154.

Senators, (U. S.) nomination and election of, 342 .

Service records, IOI.

Service requirements, standardization of, New York City, I82.

Sewage disposal, Akron, 25I.

Sewers, Chicago, 20I ; Dayton, 235 ; Detroit, 266.

Shell-fish commission, Connecticut, I50; abolition of, New Jersey, II6, II7, II8.

Shell fisheries, New Jersey, II7, I I9.

Sheriff's Office, Cook County, I11., 228, 229; Philadelphia, 2 I9.

Signal Corps, office of, handling correspondence in, 98 .

Sinking fund bonds, conversion of, Massachusetts, 124.

Sinking funds, Boston, 197; Day- ton, 235; New York State, 127, 185 .

Snow removal, Rochester, N. Y., 263.

Social service department, Ohio, I68, I70.

Social welfare department, Denver, 258.

Soldiers' relief department, Boston, I98.

Solicitor of Internal Revenue, office of, 70, 72 .

South Dakota Division of Legislative Reference, history and work, 346; publications, 347 .

South Dakota Joint Committee on Investigation of State Expenditures and the System of Accounting and Reporting, work of, I6I.

Special assessments, accounting system for, Chicago, 201.

Springfield Bureau of Municipal Research, history and work, 247-248; publications, 249.

State administration, agencies for investigating, official, II4I6I ; unofficial, I62-166.

State and local administration, unofficial agencies for investigating, I67-172.

State Board of Contract and Supply, New York State, I28.

State Board of Estimates, New York State, I28.

State Constitution, New York, I87, I88.

State fairs, Iowa, 148.

State Forester, Department of, Massachusetts, 124 .

State Government from Point of View of Administrative Law, by Frank J. Goodnow, 186.

State government, organization of, Alabama, I5I ; Connecticut, I49; Iowa, 147, 149; Kansas, I5O; Louisiana, I57; Massachusetts, 296; Minnesota, I44, 145, I46, I47; New York, I26, I27, I30, I31, I32, I77, I84-I89; Oregon, I59; Virginia, I55, I56; administration of, Colorado, I52, I54, Texas, I58; 


\section{INDEX}

work and financial administration of departments, Illinois, I35-1 38, I 42, Massachusetts, I19, I23, Pennsylvania, I33; cost of, Illinois, 332 ; consolidation of departments, New Jersey, II6, II8, II9.

State Highway Department, organization of, New York, I32.

State insurance, Virginia, 156.

State library, Illinois, I43; Ohio, I69.

State militia, business administration of, Massachusetts, 123.

State police, Connecticut, I50; New Jersey, 164, I65; New York, I65; Pennsylvania, I64, I65; problem of, in America, 165.

Stationery, New York State, I27.

Statistical work, Bureau of Insular Affairs (1913), 98.

Statistics Department, Boston, 197.

Street railroads, valuation of, Cincinnati, 223.

Streets, Akron, 252 ; Boston, I97, 198, I99; Chicago, 200, 20I, 203, 228; Cincinnati, 220, 22I, 223; Dayton, 232; Milwaukee, 240, 24I ; New York, N. Y., 306; Rochester, N. Y., 26r ; Toronto, 256.

Subtreasuries, work performed by, IIO, II2; plan to consolidate with federal reserve banks, II 2.

Subtreasury system, history of, II2.

Suffrage laws, Rhode Island, 346 .

Superannuation of civil service employees, U. S. Government (I908), 80, 82.

Supervising Architect's Office, reorganization of (1895), 70, 73.

Supervisor of Administration, Massachusetts, creation of office of, 122 .

Supplies, purchase of, U. S. Government, 68, 71, 76, 82, I00; Westchester County, N. Y., 274, 275, Boston, 199, for schools, New York City, 210, institutional, Maryland, 171, office, New York State, I27; standardization of, Cincinnati, 221, New York City, 305, Illinois, 135, 143.

Surety Bonds, elimination of, Columbus, O., I69.

Surgeon General, Office of, handling correspondence in, (I9I3), 98.

Surveys, scientific, Illinois, I43.

Swamp lands, drainage and reclamation of, Indiana, 332.

System of Financial Administration of Great Britain, The, by Wm. F. Willoughby, Westel W. Willoughby, Samuel McCune Lindsay, 43.

Taft, William H., President's Commission on Economy and Efficiency created by, 84-85; The Federal Government as an Example, I86.

Taxation, Westchester Co., N. Y., 274, 275 ; Akron, 254 ; Boston, I99; Dayton, 237; Marion, I69; Milwaukee, 239; Michigan, 336; New Jersey, I17, II9; Pennsylvania, 344; Virginia, 349 ; of trust companies, $35 \mathrm{I}$.

Tax commission, Colorado, 154.

Tax revision board, 217, 220.

Teachers' Pension Systems in the United States, by Paul Studensky, 43 .

Teachers' retirement systems, New Jersey, I65.

Telephone service, Cincinnati, 22I ; interdepartmental, 75, 82.

Tenement house inspection, Philadelphia, 217.

Tenement house legislation, $35 \mathrm{I}$; New Jersey, II8, II9; New York City, 18i.

Tennessee State Budget Commission, history and work of, 298.

Texas Joint Legislative Investigating Committee, history and work, 158; publications, I58.

Texas Legislative Reference Sec- 


\section{INDEX}

tion, history and work, 363 ; publications, 364 .

Text-book laws, state, digest of, I3I.

Text-books, cost of providing, New York State, I30, I3I.

Titles, standardization of, New York State, I78.

Toledo Public Research Bureau; Toledo Commerce Club, history and work of, 266.

Toronto Bureau of Municipal Research, history and work, 255-256; publications, 257.

Torrens system, New York City, I84; Nebraska, 338.

Town government, organization of Hempstead, No. Hempstead and Oyster Bay, N. Y., I83.

Township laws, Pennsylvania, 344.

Traction ordinance, Cincinnati, 223.

Trading with the enemy, 356 .

Training for municipal service, I86.

Training for public service, I86, I89; Akron, 252.

Training School for Public Service, 175.

Transfer of flag, 356 .

Transportation accounts, government employees, 77, 82.

Travel expenditures, government employees, 96.

Treasurer, office of, Colorado, I54; Cook Co., Ill., 225, 228, 229.

Treasury Department, commission on business methods in, 6I, 64.

Trees, Dayton, 237.

Tuberculosis, 349, $35^{2}$.

Tuberculosis Commission, Connecticut, I5O.

Twelfth census report on agriculture, $76,82$.

Typesetting machines, purchase of, 74, 8I.

Unemployment, Akron, 252.

Unexpended balances, New York State, I27.
University of Wisconsin, 290.

U. S. executive departments, business methods of, 107.

U. S. executive departments and other government establishments, laws organizing and regulating compensation and employment, etc., 7 I.

U. S. government, business conditions in executive departments, 72 ; organization of, 95 , 96 , IOI ; methods of appointment in, 95; accounting system, 96; business methods, 99 , 107.

U. S. Treasury, law organizing accounting offices, 96 .

Vacation allowances, Massachusetts, I23.

Vacations, laborers, Boston, 199.

Vagrancy, laws relating to, 336.

Vermont Legislative Reference Bureau, history and work, 347; publications, 348 .

Veto power, Nebraska, 338; in the states, 346 .

Virginia Commission on Economy and Efficiency, history and work, I54; publications, I56.

Virginia Legislative Reference Bureau, history and work, 348; publications, 349 .

Vital statistics, Philadelphia, 2 I 7.

Vocational education, Boston, 200.

Voting, compulsory, 342 ; absent, 342,356 .

Voting machines, Chicago, 228, 283.

Wages, exemption of, $35 \mathrm{I}$.

War Department, business methods, 6I, 64.

War equipment, outline for classification and codification of, 99.

Ward organization, Milwaukee, 239; Minneapolis, 245.

Warrants, U. S. Treasury, proposed change in form of, 72 .

Warwick, Walter W., mem- 


\section{INDEX}

ber, President's Commission on Economy and Efficiency, 86.

Waste paper, recovery of in U. S. government, 99 .

Water mains, Yonkers, 268, 269.

Water pipes, electrolysis of, Chicago, 228.

Water rates, Akron, 252.

Water resources, administration of, Illinois, I43.

Water revenues, collection of, New York City, I8o.

Water supply, Akron, 25I, 255; Boston, 197, 198, 199; Chicago, 201, 228, 230; Dayton, 232, 236; Milwaukee, 206; Yonkers, 269.

Weights and measures, Baltimore, 17I ; Dayton, 233; Philadelphia, 216.

Westchester Co., N. Y., Research Bureau, history and work, 272274; publications, 275.

West Virginia Legislative Reference Section, history and work of, 349.

Widows' pensions, New York State, 188; North Dakota, 34I. Willoughby, William F., member,
President's Commission on Economy and Efficiency, 86; System of Financial Administration of Great Britain, 43; Problem of National Budget, 43; Movement for Budgetary Reform in States, 43.

Window envelopes, use of, 95, 96 . Wisconsin Legislative Reference Department, history and work of, $35^{\circ}$; publications of, $35^{\mathrm{I}}$.

Wisconsin State Board of Public Affairs, history and work of, 288, 289; publications of, 290.

Workhouse, Akron, 252; Dayton, 234.

Workmen's compensation, 342; Illinois, 33I ; New Jersey, I64; Rhode Island, 346.

Workmen Compensation Commission, Connecticut, 150 .

Wyoming Bill Drafting Committee, history and work of, $37 \mathrm{I}$.

Yonkers Bureau of Municipal Research, history and work, 267-268; publications, 269. 



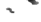




$\frac{x}{2}, 2$

$\frac{29}{4}$

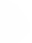


RETURN TO the circulation desk of any

University of California Library

or to the

NORTHERN REGIONAL LIBRARY FACILITY

Bldg. 400, Richmond Field Station

University of California

Richmond, CA 94804-4698

ALL BOOKS MAY BE RECALLED AFTER 7 DAYS

2-month loans may be renewed by calling

(415) 642-6233

1 -year loans may be recharged by bringing books to NRLF

Renewals and recharges may be made 4 days prior to due date

DUE AS STAMPED BELOW

SEP151000

JAN 291989

SEP 12 i990

HUTR RSG JUL. 021990 
nis

\section{U.C. BERKELEY LIBRARIES

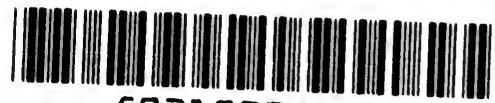 \\ C021097960}
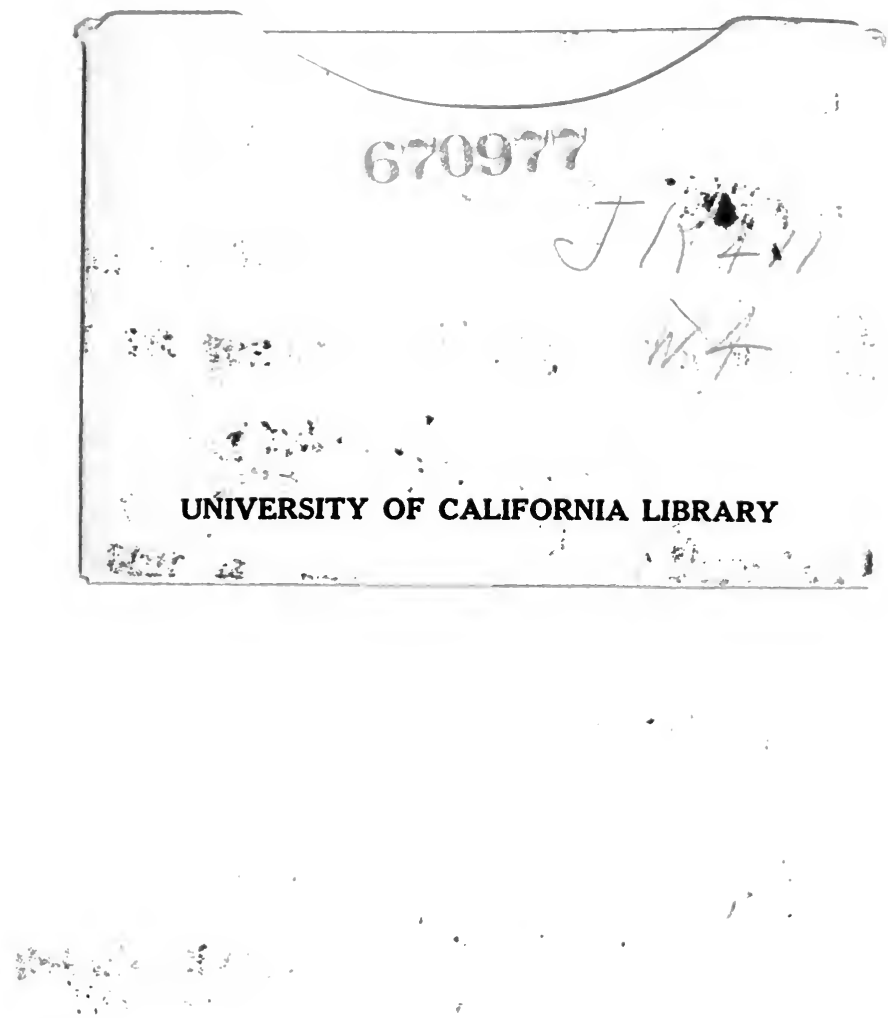
